UNIVERSIDADE DE SÃO PAULO

FACULDADE DE FILOSOFIA, LETRAS E CIÊNCIAS HUMANAS

DEPARTAMENTO DE LETRAS CLÁSSICAS E VERNÁCULAS

PROGRAMA DE PÓS-GRADUAČ̃̃O EM LITERATURA COMPARADA

ÁREA DE ESTUDOS COMPARADOS DE LITERATURAS DE LÍNGUA

PORTUGUESA

\title{
PENSAMENTO CRÍTICO-TEÓRICO DE AQUINO CORRÊA: CONSIDERAÇÕES SOBRE CRÍTICA E TEORIA LITERÁRIAS EM MATO GROSSO
}

Nancy Lopes Yung

São Paulo

2007

YUNG, Nancy Lopes. 



\section{NANCY LOPES YUNG}

\section{PENSAMENTO CRÍTICO - TEÓRICO DE AQUINO CORRÊA : CONSIDERAÇÕES SOBRE CRÍTICA E TEORIA LITERÁRIAS EM MATO GROSSO}

Tese apresentada ao Programa de PósGraduação em Estudos Comparados de Literaturas de Língua Portuguesa da Faculdade de Filosofia Letras e Ciências Humanas da Universidade de São Paulo, para obtenção do título de Doutor em Letras.

Área de concentração: Estudos Comparados de Literaturas de Língua Portuguesa.

Orientadora: Prof ${ }^{\underline{a}} \mathrm{Dr}^{\mathrm{a}}$ Benilde Justo Lacorte Caniato 

ERRATA 


\section{FOLHA DE APROVAÇÃO}

Nancy Lopes Yung

Pensamento crítico-teórico de Aquino Corrêa: considerações sobre teoria e crítica literárias em Mato Grosso.

Tese apresentada ao Programa de Pós-Graduação em Estudos Comparados de Literaturas de Língua Portuguesa da Faculdade de Filosofia Letras e Ciências Humanas da Universidade de São Paulo, para obtenção do título de Doutor em Letras.

Área de concentração: Estudos Comparados de Literaturas de Língua Portuguesa.

Orientadora: $\operatorname{Prof}^{\mathrm{a}} \mathrm{Dr}^{\mathrm{a}}$ Benilde Justo Lacorte Caniato

Aprovada em:

Banca examinadora

Prof. Dr.

Instituição Assinatura

Prof. Dr.

Instituição Assinatura

Prof. Dr.

Instituição Assinatura

Prof. Dr.

Instituição Assinatura

Prof. Dr.

Instituição Assinatura 


\section{AGRADECIMENTOS}

A realização deste trabalho só foi possível porque tive a colaboração de certas instituições e pessoas.

Por isso, agradeço, em primeiro lugar, à Universidade do Estado do Mato Grosso e à Universidade do Estado de São Paulo pela iniciativa da parceria que deu tão certo. À Prof ${ }^{-a}$ Dr $^{\text {a }}$ Benilde Justo Lacorte Caniato, minha orientadora, por todo o apoio e incentivo, e pelas inúmeras oportunidades de, sempre, me mostrar um aprendizado. À

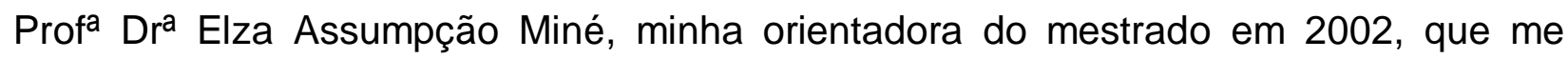
indicou o caminho. À Prof ${ }^{-a} \mathrm{Dr}^{\underline{a}}$ Tânia Macedo pelas intervenções tão necessárias. À Prof $^{\text {a }} \mathrm{Dr}^{\mathrm{a}}$ Salete Cara pela clareza com que apontava meus equívocos.Ao Prof. Ms. Taysir Mahamudo Karim, Magnífico Reitor da Universidade do Estado de Mato Grosso, pelo apoio prestado em momentos decisivos da minha formação.Um agradecimento especial ao Prof. Ms.Laudemir Zart, Digníssimo Pró-Reitor da Pró-Reitoria de Pesquisa e Pós-Graduação pela forma clara com que conduziu o Programa de Qualificação Interinstitucional USP/UNEMAT.Um agradecimento especial ao Prof. Ms Isaac Newton de Almeida Ramos, Digníssimo Diretor do Instituto de Linguagem, pelo apoio de sempre. Ao Prof. Dr.Benjamin Abdala Júnior, pelo apoio, abrindo-me as portas do Centro de Estudos Portugueses. À Márcia e à Creuza por toda a ajuda que me deram junto ao CEP. Ao Rogério Lopes Yung, meu irmão, por estar sempre me buscando e levando ao aeroporto de Congonhas, nas minhas pontes entre Cuiabá e São Paulo. À CAPES, que me concedeu a bolsa de estudos. À UNEMAT que me dispensou dos trabalhos docentes para que eu pudesse desenvolver este projeto em regime de dedicação exclusiva. Ao Jorge, secretário da Academia Mato-Grossense de Letras que sempre esteve presente me ajudando nas pesquisas para coleta de dados.

Enfim, tenho certeza de que por mais que agradeça sempre alguns ficarão de fora. Então, agradeço a estes que se julgaram esquecidos. 


\section{DEDICATÓRIA}

A Deus, que criou o mundo em seis dias e no sétimo descansou, pois havia criado o homem à sua imagem e semelhança, ser capaz de criar.

Aos meus pais, Mário (In memorian) e Geni.

Ao pai de meus filhos, Valdir.

Aos meus filhos, Aline e Henrique.

Ao meu neto, Paulo Henrique.

Aos meus irmãos, e em especial ao meu querido irmão de São Paulo, Rogério.

Às minhas irmãs, e em especial à Hilda.

A meus sobrinhos, e em especial ao Eduardo.

Às minhas sempre orientadoras em tudo, Benilde, Elza e Tânia.

Às minhas amigas das noites dos finais de semana de São Paulo -Vera, Betinha, Susanne, Léo, Elair, Irene e Bê.

Aos meus amigos das noites dos finais de semana de São Paulo - Gui, Zé Neto, Geninho e Mantovani.

Aos meus amigos de todos os dias de São Paulo, Gesuína, Seu Antônio, Jô, Edileuza, Seu João, Dona Cida.

Aos meus amigos das noites dos finais de semana de Cáceres - Zé Antônio, Flávio, Agnaldo, Élcio, Edson e Luzia.

Aos meus amigos de tereré dos finais das tardes de Cáceres Ana Rúbia, Renato, Bazé(André), Ruzin(Roosevelt). 


\section{EPÍGRAFES}

Na poesia o representar interno mesmo fornece tanto o conteúdo como o material. Contudo, na medida em que o representar também fora da arte já é o modo mais corrente da consciência, devemos nos submeter à tarefa de separar a representação poética da prosaica. A arte da poesia não pode permanecer presa a este representar poético interior, mas deve confiar as suas configurações à expressão lingüística (HEGEL, 2004: 21).

Existem palavras e designações singulares principalmente à poesia, tanto pelo lado do enobrecimento quanto pelo do aviltamento e do exagero cômicos. A poesia pode, em parte, se prender ao arcaico e, desse modo, inútil na vida comum, em parte, se mostrar principalmente como formadora progressista da língua e ser nisso de grande ousadia inventiva, desde que não aja contra o gênio da língua (HEGEL, 2004: 56). 


\section{RESUMO}

YUNG, N. L. Pensamento crítico-teórico de Aquino Corrêa: considerações sobre crítica e teoria literárias em Mato Grosso. 2007. 178 f. Tese (Doutorado)Faculdade de Filosofia, Letras e Ciências Humanas, Universidade de São Paulo, São Paulo, 2007.

Este trabalho procura explorar o ponto de vista de Aquino Corrêa, que pressupõe a adoção de um comportamento crítico diante do poema, assentado na análise da forma e do conteúdo, admitindo a existência de uma norma de uso da língua na modalidade literária capaz de expressar na obra a distinção dessas duas entidades: a forma e a matéria ou fundo. A perspectiva adotada para a realização deste estudo foi a de análise do discurso crítico com que Aquino Corrêa analisa estas duas "entidades" para determinar a função das obras, no interior do sistema literário de onde elas emergiram. Alicerçados na sua biobibliografia elegemos os pontos fundamentais que sustentam o estilo particular do escritor e os critérios que o mesmo defende para conceber o texto elevado à categoria de literário mediante o tratamento dispensado à forma e ao conteúdo. O princípio teórico fundamental desta tese assenta-se na concepção da natureza universal do texto literário constituído como expressão de um conteúdo que ganha uma forma determinada tanto no processo de escrita quanto de análise do texto, implicando em procedimentos essenciais à realização da crítica literária, a qual visualiza a obra configurada no desabrochamento simultâneo de uma estrutura e de um pensamento, no amálgama solidário de uma forma e de uma experiência individual. Nesta relação, distinguemse a literatura enquanto arte criativa e os estudos literários como um enfoque especializado do texto que possibilita à crítica traduzir a experiência criativa da literatura através de procedimentos específicos que a subsidiam e a legitimam.Neste prisma em que o texto é analisado nas suas categorias estruturais e nas relações de significação com o autor, a língua literária subordina-se a determinadas normas lingüísticas que funcionam como reguladoras dos procedimentos tanto de elaboração como de avaliação crítica do texto, promovendo "a depuração dos excessos tanto da linguagem revolucionária dos modernistas quanto dos resíduos lusófilos dos tradicionalistas" (LEITE, 2006: 31).

Palavras-chave: crítica literária; língua literária; forma e matéria poéticas; recepção; fontes; influências. 



\begin{abstract}
YUNG, N. L. Critical-theoretical thought of Aquino Corrêa: considerations about literary criticism and theory in Mato Grosso. 2007. 178 f. Thesis (Ph.D.) - Faculty of Philosophy, Letters and Human Sciences, University of Sao Paulo, Sao Paulo, 2007.
\end{abstract}

This work looks for to explore point of view of the Aquino Corrêa that ahead estimates the adoption of a critical behavior of the poem seated in the analysis of the form and the content, admitting the existence of a norm of use of the language in the literary modality capable to express in the workmanship the distinction of these two entities: the form and the contents or the deep substance.The perspective adopted for the accomplishment of this study was of analysis of the critical speech with that Aquino Corrêa analyzes these two "entities" to determine the function of the workmanships in the interior of the literary system of where they had emerged. The basis of our argument is in his biobibliography we choose the basic points that support the particular style of the writer and the criteria that the same defends to conceive the high text to the literary category by means of the treatment excused to the form and the content.The theoretical basic principle of this thesis is based in the conception of the universal nature of the literary text consisting in the place where the content in such a way gains definitive form for the process of writing how much of analysis of the text implying in essential procedures to the literary accomplishment of the critical one, which analyzes the workmanship configured in the simultaneous unclasping of a structure and a thought, in the solidary amalgam of a form and an individual experience. In this relation they distinguish it literature while creative art and the literary studies as one specialized approach from the text that it makes possible to the critical one to translate creative of literature the experience through specific procedures that subsidize it and they legitimize it. In this prism where the text is analyzed in its structural categories and the relations of means with the author, the literary language subordinates it definitive linguistics norms that they function in such a way as regulating of the procedures of elaboration as of critical evaluation of the text, promoting "the purification of the excesses in such a way of the revolutionary language of the modern movement how much of the 'lusófilos' residues of the traditionalists" (LEITE, 2006:31).

Key-words: literary text; literary critical; literary language; literary form and substance; reception; sources; influences. 


\section{SUMÁRIO}

INTRODUÇÃO

CAPÍTULO 1: Francisco Tomás de Aquino Corrêa: biobibliografia motivações e hipóteses. .20

1.1. Biobibliografia: relações entre literatura e biografia .21

1.1.1. Motivações. 39

1.2. Hipótese. 42

1.3. As interfaces de Francisco Tomás de Aquino Corrêa..............................................47

1.4. Vozes da tradição clássica em Aquino Corrêa.....................................................48

1.5. Aquino Corrêa e os gêneros literários. .51

\section{CAPÍTULO 2: A poesia em Mato Grosso a partir de Aquino} Corrêa. .55

2.1. "Poema" e não "poesia": da natureza universal do texto lírico. .56

2.2. Percursos necessários à crítica: comentário, análise e interpretação.. .57

2.3. A escrita e o estudo analítico do poema: procedimentos fundamentais à crítica literária..... 62

2.3.1. A forma e a matéria do poema. 63

2.3.2. Fronteiras da forma e da matéria poéticas: o equívoco dos juízos críticos sobre os valores poéticos. .64

2.4. Hipótese: estudos críticos da poesia em Mato Grosso

2.5. A dimensão histórica: a complexidade dos conceitos e dos contextos de surgimento da crítica literária da poesia em Mato Grosso.

2.6. Formação da consciência crítica: contextos de surgimento da crítica literária da poesia no Mato Grosso. 
3.1. Os conceitos não acabaram: poesia, história e religião..........................................98

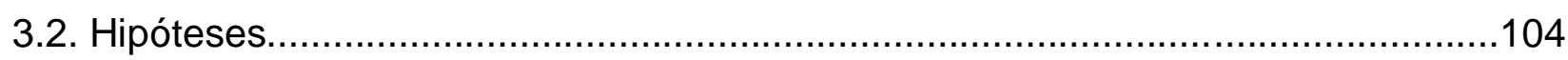

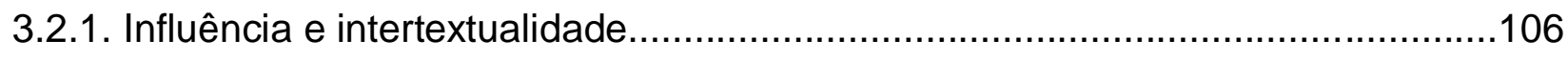

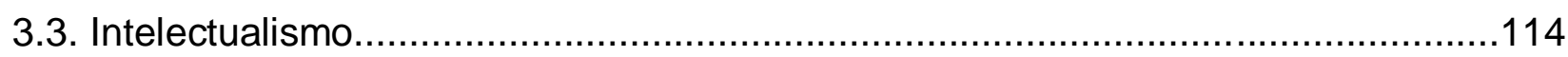

CAPÍTULO 4: Traços precursores: Convenção, tradição e

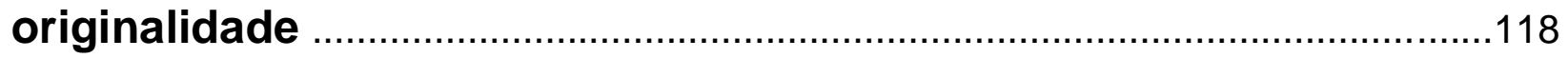

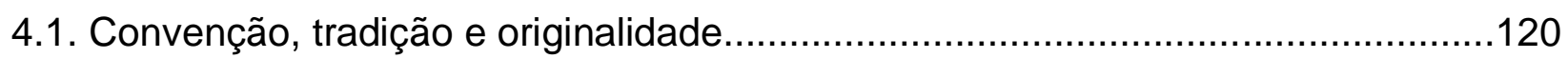

4.2. Aspectos sobre a forma e o conteúdo poéticos em Aquino Corrêa ......................133

CAPÍTULO 5: Fronteiras: a língua literária e os papéis da tradição e da

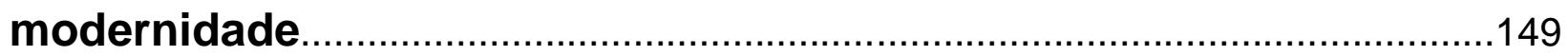

5.1. Aquino Corrêa: busca de espaço na Modernidade.............................................152

5.2. Relações críticas: o clássico e o popular, panteísmo e evolucionismo..................162

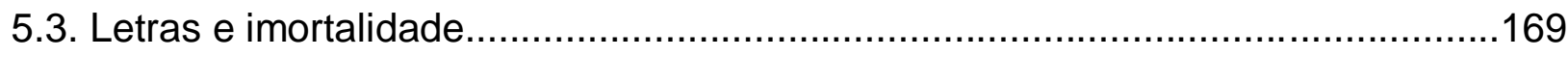

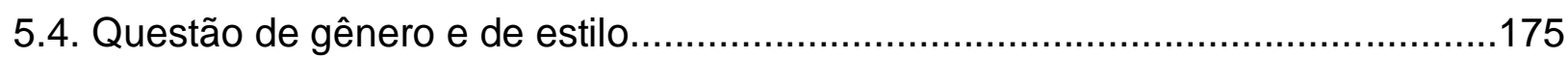

CAPÍTULO 6: Língua literária em uso: estratos da obra de arte,

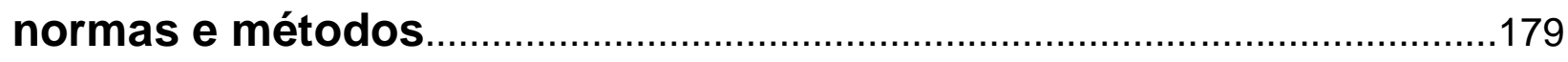

6.1. Estratos da obra literária e paradigmas de estudo analítico do poema.................181

6.2. Língua literária: obediência a que norma........................................................188

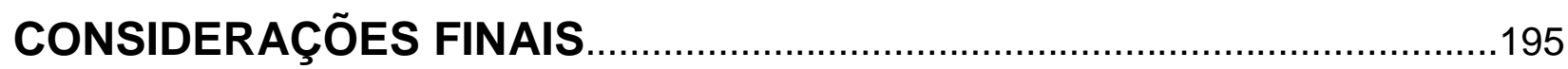

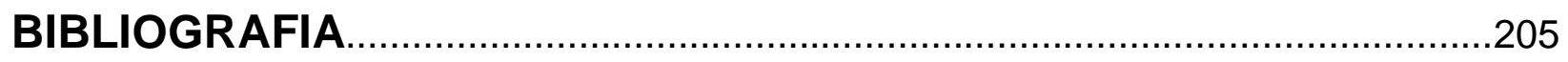

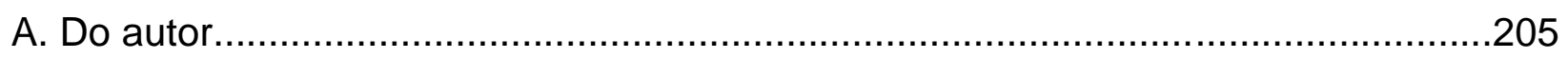

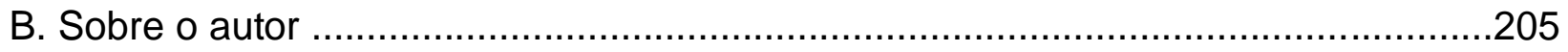

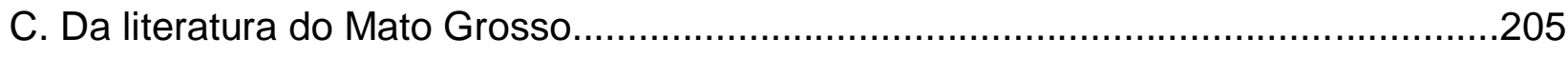

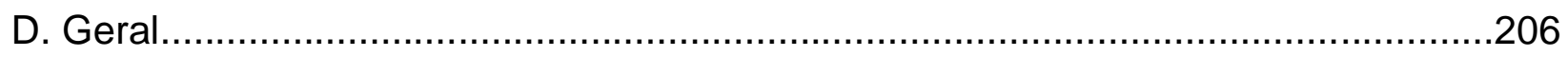




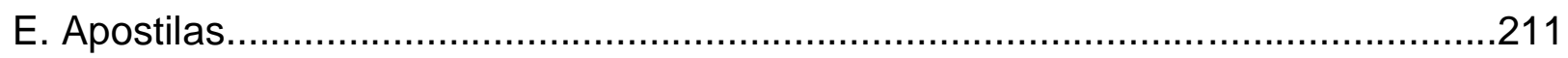

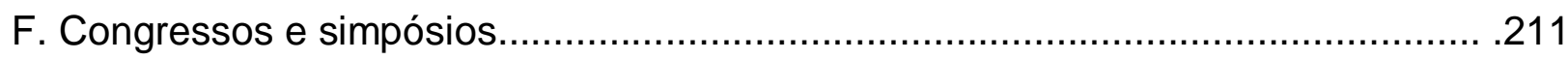

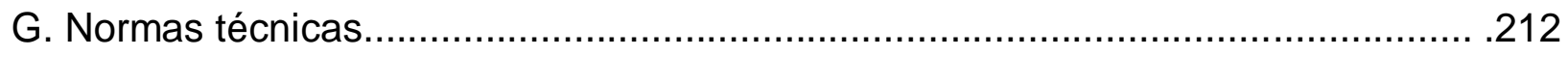




\section{INTRODUÇÃO}

Em uma palavra, não se desunam e separem violentamente o poeta e o homem, mas formem ambos uma entidade só, vinculada ao mesmo ideal $e$ aos mesmos deveres. (Aquino Corrêa, 1985 a : 31) 
A única diferença que vai do homem vulgar ao poeta, é que, enquanto aquele deseja friamente, este suspira e inflama-se; um corre, outro voa como as águias e os condores; um vai, solitário, ao seu Ideal, outro quisera arrebatar consigo, após ele, o universo inteiro; um contempla-o em silêncio, outro empunha a lira, e canta-o por toda a vida (Aquino Corrêa, 1985 a: 30).

Estas palavras escritas, em 27 de outubro de 1917, por Francisco Tomás de Aquino Corrêa, credenciado escritor mato-grossense falecido em 1956, apontam o ponto introdutório do objeto de investigação deste estudo. $O$ texto da epígrafe sugere a confluência do homem e do poeta, da mente e do coração, ambos controlados pela racionalidade da representação material.

O interesse pelo tema deste trabalho tem suas raízes no estudo desenvolvido na dissertação de mestrado Imortalidade e discursos: a presença lusitana e a língua portuguesa no espaço cultural de Mato Grosso', apresentada ao Departamento de Letras Clássicas e Vernáculas da Faculdade de Filosofia, Letras e Ciências Humanas da Universidade de São Paulo, em 2002. O estudo demonstrou que a presença lusitana em Mato Grosso, no primeiro quartel do século XX, foi modelizadora da produção literária local, registrando-se em duas vertentes, uma de natureza mais nitidamente literária, preconizada por Aquino Corrêa, e outra de caráter mais filológico, proposta por Nilo Póvoas².

As orientações referentes à literatura e à língua portuguesa, segundo o ponto de vista de Aquino Corrêa e de Nilo Povoas, foram hegemônicas até a primeira metade do

1 Fonte: DELBEM, Nancy Lopes Yung. Imortalidade e discursos: a presença lusitana e a língua portuguesa no espaço cultural de Mato Grosso. São Paulo: 2002. 272 f. Dissertação (Mestrado na área de Estudos Comparados de Literaturas de Língua Portuguesa), Departamento de Letras Clássicas e Vernáculas da Faculdade de Filosofia, Letras e Ciências Humanas da Universidade de São Paulo.

2 Nilo Póvoas (1892-1967), foi professor catedrático de Língua Portuguesa, no Liceu Cuiabano e na Escola Normal "Pedro Celestino", em Cuiabá, e em curso superior particular, no Rio de Janeiro.Advogado, jornalista, filólogo, escritor e acadêmico da cadeira 14, da Academia Mato-Grossense de Letras. 
ano de 1945, quando Rubens de Mendonça ${ }^{3}$ propõe a ruptura com o modelo português, preconizando uma estética literária mais espontânea e livre, expressa através de um texto com menos comprometimento formal.

Especificamente, visamos a estudar a importância do postulado teórico de Aquino Corrêa de deixar à margem a "filosofia do belo" e contemplá-lo, apenas através do prisma literário, que dá origem a um tipo de comportamento crítico que leva os estudiosos da literatura a defender uma norma de uso da língua na modalidade literária capaz de expressar, "à luz da crítica", a distinção, na obra literária, "de duas entidades: a forma e a matéria ou fundo" (CORRÊA, 1985 b, v.l. t. Il:18).

A perspectiva adotada para a realização deste estudo foi a de análise do discurso crítico com que os historiadores da literatura produzida em Mato Grosso analisam essas duas "entidades" para determinar a função das obras no interior do sistema literário de onde elas emergiram.

Claro que esta perspectiva de formação da consciência crítica da literatura produzida em Mato Grosso, a partir de Aquino Corrêa, filia-nos à modalidade escrita da língua portuguesa traduzida na sua forma literária através de textos considerados literários e textos críticos que documentam as tentativas de cunhar paradigmas próprios de existência literária.

Sob este enfoque, fundamentamos nosso percurso teórico, adotando o juízo crítico de Edith Pimentel Pinto que, em sua obra A língua escrita no Brasil (1992:19-46), pontua sobre a formação de uma consciência crítica da língua literária a partir do ponto de vista dos escritores românticos, que "começaram a entrever a existência da variante brasileira da língua portuguesa e a empreender a defesa de seu suposto direito a uma expressão literária própria".

A princípio, essa "expressão literária própria" circunscreveu-se no estatuto literário dado ao aproveitamento de uso de uma variante da língua nacional capaz de dar expressão à fala regional nos vários tipos de discurso de que se compõem os textos. Desta forma, origina-se uma "nova língua literária" ou uma forma literária

${ }^{3}$ Rubens de Mendonça (1915-...)-historiador e literato mato-grossense, ocupante da cadeira 9 da Academia Mato-Grossense de Letras. Segundo Hilda Gomes Dutra Magalhães(2001:111-115), Mendonça contribuiu para a implantação da estética modernista em Mato Grosso, porém o seu estilo afina-se à poesia clássica e aos ideais do Romantismo. 
calcada na oralidade. Para realizar esta operação, o texto passa a se constituir como o espaço de elaboração e de uma "transcrição manipulada" da língua que registra a própria fala do escritor, que é elevada à categoria de língua literária mediante um discreto tratamento formal.

Ora, o que é transposto do plano da oralidade para um outro plano, supostamente literário, como resultado deste tratamento estético, é uma nova forma poética de veiculação de um conteúdo que indica a penetração do regional na literatura nacional, o que, evidentemente, só se processa através dessa "manipulação" com que o escritor tenta dar forma de expressão a uma matéria poética.

Claro que esta operação demonstra a estreiteza de uma visão de literatura regional calcada apenas na reprodução da fala, sem nenhum aparato teórico mais consistente.

Como o nosso objetivo é estabelecer os princípios crítico-teóricos que realmente dêem conta de dar um perfil teórico às produções literárias de Mato Grosso, buscamos organizar nosso estudo a partir dos posicionamentos críticos de Aquino Corrêa, em relação à sua própria produção literária e às produções ainda por virem e representarem este período de transição entre uma época considerada "tradicional", e outra época literária, considerada como "moderna".

Sempre nos limitando a perceber a beleza literária através do estudo analítico dispensado à forma e à matéria poéticas, organizamos nosso trabalho em seis capítulos. No primeiro, alicerçados na biobibliografia do escritor Aquino Corrêa, procuramos delimitar o lugar do poeta, a fim de eleger os pontos fundamentais relacionados ao gênero e ao estilo literários adotados pelo escritor.

As primeiras formulações foram feitas a partir da comparação e do isolamento de alguns fatores individuais que registram ações e criações do escritor, sobre os quais, supostamente, acreditamos se assentar a temática de suas obras, tanto no aspecto da matéria poética como da forma adotada para a expressão desta matéria.

A opção pela biobibliografia como forma metodológica, ou como o método investigativo preconizado por Wellek e Warren (2003), circunscrito na abordagem extrínseca ao estudo da literatura, possibilitou-nos fazer algumas afirmações teóricas em relação à matéria e à forma das obras de Aquino Corrêa, bem como determinar o 
seu posicionamento crítico em relação à literatura brasileira produzida por escritores mato-grossenses.

A opção por este método investigativo implica em afirmar, como sugere Bakhtin (2000: 109), na sua Estética da criação verbal, que "reconhecer e compreender o princípio plástico-pictural da criação artística verbal" é o princípio fundamental da crítica literária moderna.

Esta afirmação não deixa dúvidas de que defendemos a hipótese de que a criação artística verbal está relacionada com a exterioridade do autor e do mundo espacial onde se desenrolam os acontecimentos de sua vida, os quais, quando expressos numa forma estética, concretizam-se como fatos que interessam à crítica, à proporção que se constituem como representações sócio-culturais.

Esta forma estética trata de traduzir empiricamente tanto os dados externos como internos da vida do autor, constituindo-se nas fronteiras do mundo artístico e da forma textual da própria obra de arte, ou seja, do poema.

No segundo capítulo, priorizamos estabelecer a natureza universal do texto lírico, perseguindo o postulado teórico de Aguiar e Silva (2000: 582), que o constitui no espaço em que o conteúdo poético se materializa numa forma, onde se estabelece a relação de implicação entre o "eu" do autor textual e o "eu" do autor empírico, que é, em suma, a relação estabelecida entre o poeta como visionário da matéria do texto, e o escritor, como transformador desta matéria em uma forma poética.

Neste capítulo é que se estabelece a relação de intimidade entre a forma e o conteúdo poéticos nos procedimentos de escrita do texto e de estudo analítico do mesmo, juntamente com a implicação desta relação nos procedimentos fundamentais para a realização de uma crítica literária consciente.

Nesta ótica, Machado e Pageaux (2001:113) manifestam o princípio teórico que julgamos fundamental ao exercício da crítica literária, ou seja, a crítica deve apreender numa obra literária o desabrochamento simultâneo de uma estrutura, a qual é entendida como "forma", e de um pensamento, traduzido como a "matéria", ambos concretizados no amálgama de uma forma e de uma experiência que, na gênese do crescimento da representação estética, são solidários. 
No capítulo 3, assinalamos a pertinência da relação entre a literatura e os estudos literários como atividades distintas; a literatura traduzida enquanto arte criativa realiza-se na confluência do gesto criativo e do gesto teórico, e os estudos literários, senão uma ciência, uma espécie de estudo especializado, que traduzem a experiência criativa da literatura através de procedimentos analíticos que subsidiam e legitimam a crítica literária.

Neste capítulo faz-se o enquadramento teórico-metodológico numa perspectiva comparatista, tomando os conceitos de influência e recepção crítica como eixos condutores, com o objetivo de determinar os caminhos de orientação para se exercer a crítica literária da poesia mato-grossense ancorada no binômio forma/matéria literária. Sob este prisma pensamos uma "teoria globalizante do texto literário" (NITRINI, 2000:158), analisado tanto nas suas categorias estruturais como nas suas relações com o sujeito/autor e com o sujeito/leitor.

Neste sentido, a teoria da intertextualidade, de Julia Kristeva (In: NITRINI, 2000:158), oferece respostas satisfatórias para pensarmos teoricamente a crítica literária sob o ângulo das fontes que influenciaram a formação intelectual de Aquino Corrêa.

No capítulo 4, entre outros aspectos da contribuição da estética da recepção na renovação dos estudos das influências e fontes literárias, priorizamos aquele que paralelo à historiografia literária substancialista, centrada no estudo da obra e do autor, propõe uma historiografia mais abrangente voltada para o leitor crítico. Para tratar do resultado complexo desta recepção, nas relações de coletividade assumida por Aquino Corrêa, apoiamo-nos nos estudos e posicionamentos críticos de historiadores e críticos da literatura mato-grossense para dar corpo teórico aos pressupostos críticos sobre os quais julgamos assentar a crítica da poesia produzida por escritores mato-grossenses.

No capítulo 5, inseridos no clima de rupturas que marcou as primeiras décadas do século XX, procuramos, a partir de Aquino Corrêa, encontrar os critérios utilizados pelos estudiosos da literatura, para pensar criticamente a poesia produzida em Mato Grosso, no percurso da busca de espaço na modernidade. 
Para a realização deste capítulo, valemo-nos dos estudos comparativos para estabelecer a distinção necessária entre a linguagem literária, que sustenta a literatura, e a linguagem científica, constituída como aspecto fundamental à crítica literária.

No capítulo 6, procuramos priorizar uma visão de obra de arte, perseguindo a orientação teórica de Wellek e Warren (2006), que a concebe como um sistema normatizado, que concentra, em seu interior, uma rede de normas e de conceitos intersubjetivos. Neste sentido, estabelecemos uma relação de afinidade de ordem teórica e crítica entre Marli Quadros Leite, em sua obra Metalinguagem e Discurso: a configuração do purismo lingüístico (2006), e Aquino Corrêa, no seu discurso, "O belo nas letras" (1985 c: 13-27), em defesa de uma produção poética assentada no princípio crítico de elaboração da forma e da matéria poéticas, através da língua, na sua norma literária.

Sob este aspecto vimos que a língua literária subordinada a determinadas normas lingüísticas promove "a depuração dos excessos tanto da linguagem revolucionária dos modernistas quanto dos resíduos lusófilos dos tradicionalistas" (LEITE, 2006: 31), preenchendo-se de aspectos individualizantes que, através dos estudos crítico-literários, determinam formas muito particulares de expressão que garantem, no interior do macrossistema das literaturas de língua portuguesa, a individualidade literária de cada um dos oito países de fala portuguesa.

Nas considerações finais, procuramos considerar que os diferentes modos de ver as obras literárias é que garantem as originalidades de uma literatura emergente. Estas originalidades são expressas através da língua literária subordinada a determinadas normas lingüísticas, que funcionam como reguladoras dos procedimentos tanto de elaboração do objeto estético como de avaliação crítica do texto literário.

Atentos ao que pode interessar à teoria e à crítica literárias, destacamos nos estudos de pesquisadores da literatura produzida em Mato Grosso, apresentados no X Congresso Internacional da Abralic, realizado no Rio de Janeiro, no período de 31 de julho a 04 de agosto de 2006, determinados aspectos individualizantes de obras de escritores mato-grossenses, os quais julgamos serem pertinentes para demonstrar, através de uma visão interativa, o funcionamento das obras no interior do sistema de onde elas emergiram. 


\section{CAPÍTULO 1}

\section{Francisco Tomás de Aquino Corrêa: biobibliografia, motivações e hipóteses}

Em cada homem que vem a este mundo, renova-se a grande cena paradisíaca. Recebe ele na fronte a inspiração, que o destina ao Infinito. $E$, é a luz desse Infinito que o envolve todo e o deslumbra, com a réstia fulgurante dos seus três raios divinos: a Verdade, o Belo e o Bem. (CORRÊA, 1985 a: 25). 


\subsection{Biobibliografia: relações entre literatura e biografia}

$\mathrm{Na}$ terceira parte da sua Teoria da Literatura e metodologia dos estudos literários, Wellek e Warren (2003: 83-93), ao tratar sobre a abordagem extrínseca ao estudo da literatura, apontam "métodos que se ocupam do contexto, do ambiente e das causas externas", que muitos estudiosos da literatura julgam motivar a criação do texto literário. Para o desenvolvimento dos nossos estudos, adotamos um destes percursos investigativos, ou seja, a biobibliografia de Francisco Tomás de Aquino Corrêa, por entendermos que é a partir do estudo minucioso de dados referentes à vida e à obra do escritor que encontraremos respostas para pensar a produção literária do poeta e o discurso crítico com que este pensava teórica e criticamente a poesia produzida em Mato Grosso, no contexto de final de século XIX e início de século XX.

Atentos ao que os críticos afirmam em relação ao valor exegético dos estudos que esclarecem as condições sob as quais uma literatura é produzida, e conscientes de que toda a história, todos os fatores ambientais e socioculturais se constituem em contextos que moldam a obra de arte, procuramos atentar também para os problemas decorrentes deste tipo de avaliação que não responde, satisfatoriamente, às questões relacionadas à descrição estrutural do poema, à sua análise, e à conseqüente avaliação de aspectos textuais que dão ao texto o status de literário.

A princípio, optando por não fazer a distinção entre o texto em prosa e o texto em verso, esclarecemos que esta opção metodológica nos possibilita isolar e comparar determinados fatores individuais relacionados à vida de Francisco Tomás de Aquino Corrêa, nos quais, supostamente, acreditamos ser determinantes de uma temática característica presente nos seus poemas, bem como nos propicia fundamentar teoricamente o discurso do escritor em torno da sua concepção de texto literário.

Observados os princípios fundamentais dos estudos efetuados sob este ângulo investigativo, constatamos a existência de quatro grupos que se distinguem entre si de acordo com a série de ações e criações humanas que os estudiosos isolam para, a partir dela, atribuir uma influência determinante da criação da obra de arte.

Um grupo considera a obra como o produto de um criador individual e conclui que esta pode ser investigada através da biografia e da psicologia do autor; outro 
procura os fatores determinantes da criação literária na vida institucional do homem, isto é, "nas suas condições econômicas, sociais e políticas"; outro grupo tem a explicação causal da obra de arte, partindo de outras criações coletivas da mente humana, que registram a história das idéias, a teologia e outras artes; e, por fim, há o grupo que busca explicitar a obra de arte com base numa "certa atmosfera ou clima de opinião vigente", ou numa certa "força unitária" abstraída das características de outras obras de arte.

Procurando não pecar por excessos interpretativos, nem privilegiar aspectos que pouco acrescentam ao que já existe em termos críticos, em relação às obras de Aquino Corrêa, mantivemos coerentemente coesos aspectos referentes aos quatro grupos. Extraímos da biografia do escritor e da psicologia do autor elementos referentes à matéria das suas obras; na vida institucional do cidadão, na atmosfera reinante no ambiente de seu desenvolvimento educacional e na adoção do comportamento aplicado na leitura de obras clássicas da literatura universal, buscamos as raízes do discurso crítico do escritor referente à arte literária bem como a sua filiação genérica.

Assim, teoricamente apoiados, percebemos que a opção por este método investigativo nos possibilita fazer algumas afirmações mais modestas sobre a obra de Aquino Corrêa, e estabelecer um certo grau de relação entre a matéria poética dos seus poemas, os princípios críticos presentes em seus discursos e os contextos sociais de onde eles emergiram.

Num outro ângulo do estudo, apresentamos questões relacionadas à teoria e crítica literárias na história da literatura mato-grossense, centrados na distinção na obra de arte de uma forma e de um conteúdo poéticos, procurando dar relevância aos contextos sociais, tendo em vista o caráter de coletividade da poesia.

A pessoa do poeta interessa-nos a partir da sua capacidade de expressar, através da elaboração de um texto, os aspectos que dizem respeito a uma coletividade. A palavra coletividade traduz, neste trabalho, o grupo de estudiosos, historiadores e escritores que, naquele contexto finissecular, empenhavam-se em discutir e traçar os parâmetros basilares da cultura literária mato-grossense.

Segismundo Spina, na introdução da sua obra Na madrugada das formas poéticas (2002: 13-42), apresenta um estudo sobre o mundo das formas poéticas 
elementares e atribui à poesia um caráter coletivo porque ela se liga intimamente ao modus vivendi de uma comunidade, porém, a sua realização textual subordina-se à existência de alguém que nesta comunidade se distingue, por possuir qualidades e domínios específicos da linguagem poética, capaz de expressá-la.

Apropriamo-nos deste juízo crítico de Spina (2002) para explicitar o mote de atribuirmos a Aquino Corrêa o papel de precursor de uma crítica literária fundamentada no estudo analítico do poema. Para atingirmos este propósito, privilegiamos filtrar da formação educacional de Aquino Corrêa os antecedentes intelectuais, os inspiradores que se supõem tenham dado o suporte necessário para fundamentar teórica e criticamente a sua formação literária, e explicitar questões mais diretamente relacionadas às formas poéticas preferidas do escritor, aos gêneros aos quais este se filia, o lírico e a oratória, e ao estilo literário que o individualiza na literatura produzida em Mato Grosso.

Embora a relevância precisa dessas relações possa escapar-nos inteiramente, e também porque, retomando o juízo crítico de Wellek e Warren (2003), a explicação causal é um método superestimado nos estudos literários, uma vez que não dá conta de solucionar os problemas que referenciam os estudos analíticos da obra de arte e a avaliação da mesma, esta abordagem metodológica é o que mais significativamente nos permite estabelecer a relação entre a matéria e as formas poéticas adotadas pelo escritor para expressá-la, e o modo particular com que ele concebe criticamente a obra de arte assentada na beleza da forma e da matéria.

No essencial, esta abordagem metodológica coloca-nos a causa mais evidente dos poemas de Aquino Corrêa, girando em torno da sua personalidade, da sua formação educacional, em particular, e da totalidade de espaços em que esteve presente.

Muito a propósito, servimo-nos da biobibliografia de Aquino Corrêa, como o método de estudo literário mais antigo e bem estabelecido que mais objetivamente responde ao que queremos saber de Aquino Corrêa: encontrar o homem de gênio, modelador do seu desenvolvimento emocional, moral, intelectual e cultural, cujas ações e criações são tomadas como dados materiais necessários para desenvolver este 
estudo e explicitar a forma particular como ele pensava criticamente o desenvolvimento da poesia em Mato Grosso.

\section{$\underline{1885}$}

Ele nasceu Francisco Tomás de Aquino Corrêa, quarto filho de Antônio Tomás de Aquino Corrêa e Maria D’Aleluia Gaudie Ley Corrêa, em 2 de abril, na Chácara Bela Vista, situada à margem esquerda do rio Cuiabá, no bairro chamado Terceiro, localizado nos arredores de Cuiabá, capital do Estado de Mato Grosso. Nascido em uma família com princípios profundamente cristãos, desde o nascimento, já se vem determinando o caráter de disciplina religiosa com o qual sua vida seria conduzida. Em homenagem a São Francisco de Paula, recebeu pelo batismo o nome de Francisco.

\section{$\underline{1890}$}

Aos cinco anos de idade fica órfão de mãe.A irmã mais velha, Eulália, e a mais nova, Regina, abraçaram a vida religiosa na Congregação das Filhas de Maria Auxiliadora; o irmão Manuel, segundo filho da família, seguiu a carreira militar, transferiu-se para o Rio de Janeiro, onde faleceu como General do Exército.Tais fatos furtaram-lhe, prematuramente, os contatos maternais e o convívio com os irmãos e aproximaram-no de ambientes religiosos, onde predominava a presença masculina. Os versos - "Fugiume assim a meninice pura, sem beijos, sem carícia, sem doçura. Ó minha mãe, sem ti!" (CORRÊA, 1908) ${ }^{4}$ - retirados do poema Caveira Idolatrada, escrito por Aquino Corrêa, em 1908, em Roma, significativamente, registram a falta da presença materna, na vida do homem, cujo reflexo se dá, na obra do poeta, na sublimação quase filial à figura da Virgem Maria.

\section{$\underline{1892}$}

Inicia os estudos de alfabetização no Colégio São Sebastião, cujos princípios de instrução perseguem a rigorosa disciplina dos padres salesianos, que tem Deus como princípio fundamental para a vida eterna.

\footnotetext{
${ }^{4}$ Fonte: COMETTI, 1994: 26.
} 


\section{5}

Matricula-se no Seminário da Conceição, uma casa de formação para o sacerdócio, que mais tarde, por falta de aspirantes à vida religiosa, e de professores com formação adequada, transformou-se em educandário aberto.

\section{7}

Entre os anos de 1897 e 1898, os dois últimos anos de vida do Seminário da Conceição, consta que Aquino Corrêa ministrou aulas de língua francesa, fato que suscitou o questionamento do seu biógrafo Padre Pedro Cometti, se seria por falta de professores ou excepcional capacidade do adolescente (COMETTI, 1994:39). Contando nesta época com doze anos de idade, consta ter lido o livro de orações e reflexões cristãs, O jovem instruído, de Dom Bosco. Este fato acentua o juízo crítico sobre a disposição em moldar sua vida com rigorosos princípios religiosos de disciplina.

\section{$\underline{1899}$}

Não existindo mais o Seminário da Conceição, matriculou-se no Liceu Salesiano São Gonçalo, onde entrou de corpo e alma na família salesiana. Com quatorze anos ministrava aulas particulares das línguas portuguesa e francesa. Neste contato prematuro com a sistematização de duas línguas neolatinas, localizamos sua vocação e gosto pelo vernáculo e pela poesia.

\section{0}

Com quinze anos, lê uma versão de Vida de Agrícola, obra mista que funde literatura e história, de autoria de Públio Cornélio Tácito (55 - 120 d.C.), escrita em 98 d.C., que, no âmbito literário, registra o elogio fúnebre exaltando a figura de Júlio Agrícola, sogro de Tácito, e, no histórico, à moda do poema épico, narra aspectos da vida de Agrícola que foi cônsul e emérito magistrado que havia completado, como general, a conquista da Britânia, durante o reinado de Domiciano. Também se registra desta época a leitura de Imitação de Cristo, obra da literatura vocacional, de autor anônimo, cuja primeira 
publicação data do século XV. A reedição de 1441 é atribuída ao padre alemão Tomás de Kempis. Seu texto é auxiliar à oração e às práticas devocionais pessoais. A constatação da leitura destas duas obras interessa-nos, em particular, por considerarmos o gênero e o estilo dos escritores e obras que desde cedo influenciaram a formação literária de Aquino Corrêa. Segundo o próprio Aquino Corrêa, os quatro volumes da obra Imitação de Cristo transcendem de poesia de amor, acrescentando que o seu autor foi considerado por Auguste Comte como um dos grandes poetas que floresceram desde Homero a Walter Scott (CORRÊA, 1985, v.I, T.I: 37).

\section{1}

Consta deste ano a escrita do poema $A$ Virgem de Dom Bosco (CORRÊA, 1985, v.l, t.I: 185), canto composto por doze oitavas, cujo tema é recorrente nos poemas do escritor. Utilizando-se insistentemente de apóstrofes, o poeta faz a exaltação de Nossa Senhora, cuja figura Dom Bosco ensinou a família salesiana a amar, invocando-a sempre com o título de "Auxiliadora". Tal era o amor e devoção de Dom Bosco por Nossa Senhora que esta também ficou conhecida com "Virgem de Dom Bosco".

\section{2}

Ingressou no Noviciado dos Salesianos de Dom Bosco, em Cuiabá. Neste período, compõe o poema Hino Colegial, uma exaltação às ações educacionais dos padres salesianos, e Napoleão e Dom Bosco, um canto que se aproxima do gênero épico contrapondo-se ao heroísmo da cruz, referência à incursão dos padres salesianos pelos sertões com a missão de evangelizar, o heroísmo da espada, referência aos militares, desbravadores dos sertões, cuja missão era conquistar territórios e expandir o poder político (CORRÊA, 1985 a, v. I, tomo I:188-189).

\section{$\underline{1903}$}

Ordenou-se sacerdote e iniciou o curso de Filosofia. O soneto Um ano mais e o Hino da infância a Maria são composições escritas neste período, desenvolvendo a temática sobre a efemeridade das coisas materiais e a divinização da figura feminina, colocando como valores verdadeiros aqueles que são representados pela família e pela pátria. 


\section{4}

Vai para Roma e matricula-se na Academia de Santo Tomás de Aquino e na Universidade Gregoriana. Data, deste ano, a escritura do soneto Morto, que traz como mote o Cap. II, versículo 3, da Epístola de São Paulo aos Colossenses "porque já estais mortos, e a vossa vida está escondida com Cristo, em Deus". A composição destacada reflete alguns traços do barroquismo, esse barroco que deu origem ao rococó, apresentando formas rebuscadas e preocupação decorativa com a matéria do poema, como é o caso das oposições propostas pelo autor debatendo a vida e a morte, a efemeridade e os apelos de apego às coisas da terra, à liberdade e o temor diante da entrega total à vida religiosa.

Um ano vai que, ao bimbalhar dos sinos, Minha mortalha enfiei.Foi sepultura A solidão.Sobre ela a Virgem pura O manto abriu em crespos azulinos.

Lá fora vibra a mocidade em hinos, Beijando a rosa que tão breve dura... Adeus, ó mundo! Essa grinalda impura Que vale a troco dos lauréis divinos?

Há mais volúpia onde a alma se me aninha, Tem mais perfumes de Madona o manto, Tem mais amor dum Deus o coração!

Velai, ó Anjos, sobre a campa minha:

Fazei que da sereia o infindo canto, Ai! Não me acorde desta morte, não! (CORRÊA, 1985 a: 196)

\section{5}

Neste ano, as composições poéticas Carta a Armindo, em homenagem ao Padre Armindo Maria de Oliveira, poeta e colega de noviciato do autor; Carta Epitalâmica, em homenagem às núpcias do amigo Francisco Pio Bueno; Os meus mortos, em homenagem ao seu professor de alemão Hermann Lampe; e Carta, escrita quando o poeta estava em Genzano (Roma), em homenagem aos primeiros jovens bacharéis mato-grossenses, graduados em 30 de julho de 1905, no Liceu Salesiano de Artes e 
Ofícios São Gonçalo, de Cuiabá, marcam mais sensivelmente a temática do exílio e da ausência, manifestada sob uma forma que mescla os gêneros lírico e epistolográfico.

\section{8}

Doutorou-se em Teologia. Este foi o ano em que o poeta mais produziu. Residindo em Roma, as composições insistem no tema do exílio, nas exaltações e na criação de imagens que remetem aos valores pátrios, à religiosidade e às referências femininas, sempre projetadas na figura da Virgem Maria. Datam, deste ano, as composições poéticas: Hino, da peregrinação brasileira a Roma, poema épico misto de narração e exaltação que narra em três partes a peregrinação dos brasileiros a Roma, sendo que a parte I narra a partida do Brasil, a parte II narra a chegada a Roma e a III registra a exaltação ao Papa; Em A Primavera, o poeta exalta a adolescência e a juventude da vida; Boninas Murchas, espécie de elogio fúnebre em memória de três índios bororos mortos em São Paulo; Por ti, canto de exaltação à Virgem Maria; Elegia, homenagem a um amigo, e O Padre Rua, poesia em homenagem ao Reitor- mor dos Salesianos, Padre Michele Della Rua (CORRÊA, 1985 a: 65-87). Num outro momento temático, registram-se as composições Despedida, dedicada ao Conselheiro Rodrigues Alves em sua partida de Roma; o soneto Bernadette, através do olhar inocente da criança explica os mistérios que habitam o imaginário popular e que a ciência não dá conta de responder; e referencia Santa Bernadette de Lourdes, que foi beatificada em 1925, e canonizada em 1933. Segundo crença dos católicos, aos 14 anos de idade, Bernadette viu a Virgem Maria, que Ihe declarou ser a Imaculada Conceição. Observadas as datas de beatificação e canonização de Bernadette, Aquino Corrêa escreveu o soneto dezessete anos antes da celebração de tais fatos; em Filomela, designação poética do rouxinol, e na composição Sub tegmine fagi, a mitologia greco-latina se manifesta. A citação de palavras de Virgílio reafirma a temática do exílio e evoca o sossego idílico, na referência feita ao pastor Melibeu que, saudoso da pátria, lamenta sua sorte de exilado, enquanto louva a despreocupada e ociosa vida de Títiro, o qual recebera de Otávio permissão para ficar em suas terras, e se limita a ficar deitado sub tegmine fagi "sob a sombra da faia", tocando sua flauta (CORRÊA, 1985 a:139-142); em Abismos, o 
tema do exílio invoca o vazio provocado pela distância da pátria e faz referência à Canção do exílio, de Gonçalves Dias.

Graças, meu Deus!O abismo invoca o abismo:

E esse, que me gelara de terror,

Lembrou-me essoutro, em que sorrir eu cismo:

Teu infinito amor! (CORRÊA, 1985 a:144)

\section{9}

Em janeiro deste ano, em Roma, já havia recebido todas as Ordens Menores e Maiores da Igreja. Foi ordenado presbítero. Retorna ao Brasil. Datam, deste ano, as poesias Miserere!, termo que traduzido do latim significa "tem piedade", e Saudação, que desenvolvem a temática de exaltação, em forma de elogio ao Padre Helvécio Gomes de Oliveira e ao Monsenhor Chico de Paula, figuras de referência na vida do escritor e do religioso (CORRÊA, 1985 a:65 e 135). Foi neste ano que a revista escolar Mato Grosso publicou o que nós consideramos a primeira crítica efetiva da produção poética de Aquino Corrêa: "A penugem do bigode começa-Ihe apenas a apontar, e, entretanto, vemo-lo lançar produções que, quer na sua forma como em seu conteúdo, dão-nos as proporções de um fenômeno promissor, de um desenvolvimento precoce" (COMETTI, 1994:39).

\section{$\underline{1910}$}

Regressa a Cuiabá. No Liceu Salesiano São Gonçalo leciona Língua Portuguesa, Latim e História, além de ser nomeado diretor, cargo que exerceu até 1914. A partir deste período, as composições poéticas apresentam uma temática mais diversificada e mesclada por gêneros diversos, apontando para novos contatos e referências que acentuam o caráter das relações intertextuais na esfera dos estudos literários. Os temas se diversificam em textos de exaltação e de homenagem a pessoas ou ocasiões especiais, sendo o caso de O anjo do poeta, elogio fúnebre a Lúcio de Mendonça, gênio criativo, escritor, poeta e jornalista brasileiro, irreverente, polêmico, ateu e anticlerical, um dos idealizadores da Academia Brasileira de Letras e sócio fundador da cadeira 11 (CORRÊA, 1985 a: 60). Intensifica-se o desenvolvimento da temática de 
exaltação à pátria através de $A$ bandeira do Brasil, e à natureza local através de poemas como Juqueri e A chimbuveira. Em tom elegíaco, as homenagens se intensificam nos poemas, Gratidão, homenagem de uma aluna à sua mestra; Buenadicha, homenagem ao irmão pelo batismo da primeira filha; $O$ anjo do teu berço, homenagem à Carmelita, pela passagem do segundo aniversário; $O$ padre velho, homenagem ao missionário salesiano Padre Rafael Traversa, que recebeu dos índios bororos o apelido de "padre velho", e Genetlíaca, homenagem a Costa Ribeiro, desembargador, jornalista, advogado e político mato-grossense, que dado o fato de ele ter tido um início de vida muito difícil, transformou-se num grande incentivador dos jovens da sua época (CORRÊA, 1985 a: 115-134). Na data de 31 de julho, registra-se o pronunciamento do discurso $A$ noiva dos sábios, ao paraninfar uma turma de bacharéis em Letras do Liceu Salesiano. O discurso é considerado por nós como sendo de vanguarda por referenciar posicionamentos críticos do autor em relação à liberdade de pensamento e à relação entre ciência e fé (CORRÊA, 1985 b, vol. II, tomo I:15-24).

\section{1}

As temáticas desenvolvidas pelo autor se expandem em versos de exaltação à Pátria e a figuras políticas da época. É o caso da poesia $A$ cruz e o Brasil, composta por 15 décimas, com versos octossílabos, de exaltação à Pátria (CORRÊA, 1985 a: 55), bem como Bem-vindo que enaltece a atuação política do senador mato-grossense Antônio Azeredo (CORRÊA, 1985 a: 113).

\section{$\underline{1912}$}

As composições Patriota em flor e Adeus, respectivamente, registram os posicionamentos do autor em relação à consciência crítica de formação do cidadão. $\mathrm{E}$ Eu quisera e $A$ meu pai são composições que exaltam a figura paterna e materna (CORRÊA, 1985 a:108-111), registrando um novo posicionamento do escritor em relação à família. 


\section{3}

Datam deste ano a poesia $A$ Inocência (CORRÊA, 1985 a: 52), escrita quando o poeta era professor e diretor do Liceu Salesiano São Gonçalo; o soneto Francisco de Sales exalta a figura do titular e patrono da Congregação Salesiana, criada por Dom Bosco, sob a proteção de Maria Auxiliadora, bem como as poesias O meu lírio, O Santuário e Uma rosa a papai, todas as composições revelam o eu-lírico do poeta através de outras vozes. No caso das composições citadas, elas expressam a voz da criança, ora em homenagem, ora em agradecimento (CORRÊA, 1985 a: 100-103).

\section{4}

Em dois de abril é nomeado, pelo Papa Pio X, titular do Bispado de Prusíade e Auxiliar do Arcebispo da Arquidiocese de Cuiabá, sendo, então, o primeiro bispo salesiano do Brasil e das Américas, e o mais jovem do mundo católico.A composição Brinde Infantil retoma a exaltação da figura paterna.

\section{5}

Em 1ํ de janeiro, aos 29 anos, toma posse como Bispo Titular da Prusíade e Auxiliar do Arcebispo da Diocese de Cuiabá. Adota o nome Dom Francisco de Aquino Corrêa.Os poemas Ponto de interrogação e $O$ Colégio do Carmo enfocam a figura feminina e refletem posicionamentos críticos do autor quanto aos questionamentos e dúvidas próprias da adolescência em relação ao mundo exterior e à decisão de seguir o caminho de entrega à religião.

\section{$\underline{1916}$}

A poesia $A$ mim o céu (CORRÊA, 1985 a, v. I, tomo l: 49-51) propõe a leitura do verso de autoria da Irmã Teresa do Menino Jesus, designação canônica da francesa Marie Françoise Thérèse Martin,"Do mundo passou a fugitiva imagem...a mim o céu!”, traduzindo a transitoriedade dos valores materiais. Tal incursão localiza o escritor no universo das referências à figura feminina no ambiente de formação religiosa. A poesia

${ }^{5}$ Traduzido de "Du monde elle a passe la fugitive image... A moi le ciel!" - Souer Thérese de l'Enfant Jésus. (In CORRÊA, 1985 a, p. 49), 
é composta por cinqüenta e seis versos decassílabos, com rimas alternadas, formando seis blocos. Cada bloco é composto por dois quartetos, sendo que o último verso do primeiro registra uma interrogação ou uma exclamação, e o último verso de cada quarteto finaliza com a exortação $A$ mim o céu!, conotando a única verdade absoluta. Data, também, deste ano, o texto crítico escrito em forma de carta, que consta como prefácio da quinta parte da obra Odes, que o poeta denominou de "Diversões", ou "lazeres literários". O texto revela a preocupação do intelectual em relação à revisão e à tradução de textos poéticos escritos em latim e em outras línguas (CORRÊA, 1985 a, v. I, tomo I: 211-214).

\section{$\underline{1917}$}

A partir deste ano, acentuam-se as preocupações do escritor em relação à vida cultural do Mato Grosso.Em onze de outubro deste ano, segundo Corsíndio Monteiro da Silva, biógrafo de Aquino Corrêa, graças ao perfil de simpatia, popularidade e ao brilho da inteligência do sacerdote, ele é eleito, por sufrágio indireto, Presidente do Estado de Mato Grosso. Com a sua projeção política, o escritor passa a implementar ações que, mais significativamente, institucionalizam a cultura em Mato Grosso. Publica-se a primeira edição da obra Odes, em dois volumes, contendo poesias em língua portuguesa e em latim, traduções e versões compostas entre os anos de 1899 a 1917. Data, deste ano, a escrita dos poemas de exaltação $O$ decano dos bispos brasileiros e Carme jubilar, o primeiro, em homenagem ao 80ํaiversário de D. Carlos Luís D'Amour, Arcebispo de Cuiabá, e o segundo, exalta as religiosas Filhas de Maria Auxiliadora, pela passagem do $25^{\circ}$ aniversário da sua chegada ao Brasil, e também o soneto Luz e pão, escrito para o breviário do Padre Armindo Maria de Oliveira (CORRÊA, 1985 a: 91-94), que traduz a necessidade humana de "luz para a razão" e "pão para o coração" mediante os princípios da religião cristã. Data deste ano, especificamente, em 27 de outubro de 1917, a escrita do discurso crítico que foi publicado com o nome de Prelúdio, na apresentação da obra Poética: Odes (CORRÊA, 1985 a, v. I t. II: 21-45), registrando as considerações críticas e teóricas do escritor mato-grossense em relação à arte poética. $O$ discurso que a princípio recebeu a designação de Bispo e Presidente de Estado foi pronunciado por Aquino Corrêa, no 
salão nobre do Jornal do Comércio, no Rio de Janeiro, em 25 de outubro de 1917, ao aceitar a sua candidatura à Presidência do Estado de Mato Grosso. Prestamos atenção especial a este discurso nesta tese, por entendermos que o mesmo se constitui no material efetivo que define o espaço do poeta, do político e do religioso, expresso através do questionamento que o próprio escritor faz da postura de Platão, que, no planejamento da República ideal "excluiu da administração os poetas... seria por incompatibilidade das musas com o Governo?" (CORRÊA, 1985 b, v.II, tomo I: 63-75). A publicação da obra Odes representa o resultado de um processo que, segundo Antonio Candido, reflete as influências concretas dos fatores socioculturais ligados à estrutura social, aos valores e ideologias e às técnicas de comunicação, marcando três momentos da produção artística: a princípio, o artista sob o impulso de uma necessidade interior, orienta-se segundo os padrões da sua época; segundo, escolhe certos temas e formas de expressão que refletem este momento, e por último, manifesta a síntese resultante deste processo agindo sobre o meio (CANDIDO, 2000: 21).

\section{$\underline{1918}$}

Assume o governo do Estado de Mato Grosso, e inicia uma verdadeira cruzada em favor da criação de órgãos públicos de incentivo à cultura, bem como incentiva a criação de jornais e revistas, cujo ensejo maior era a expansão cultural do Estado.

\section{$\underline{1919}$}

Por época das comemorações alusivas ao bicentenário de fundação da cidade de Cuiabá, fundou o Instituto Histórico e Geográfico do Mato Grosso, e compôs a letra do Hino de Mato Grosso. Publicou a primeira edição de Terra Natal, obra que reflete o percurso literário de Aquino Corrêa pela história do Mato Grosso. 


\section{1}

Fundou o Centro Mato-Grossense de Letras. Foi elevado a Arcebispo Metropolitano. Escreveu o discurso Dante Alighieri, pronunciado na comemoração do 6º centenário da morte do poeta homenageado. Neste discurso, o escritor estabelece os critérios gerais para distinguir prosa e poesia e prosa-poética (CORRÊA, 1985 b, v. II, t. I: 81-98).

\section{2}

Toma posse solene no Arcebispado da Arquidiocese de Cuiabá. É eleito sócio efetivo do Instituto Histórico e Geográfico do Brasil. Publica a segunda edição da obra Terra Natal. O discurso No Ipiranga, pronunciado por ocasião da romaria cívica dos alunos salesianos a São Paulo para comemorar o Centenário da Independência do Brasil, em 12 de outubro de 1922, estabelece um entrecruzamento de vozes, através das quais se identifica a mesclagem entre os gêneros lírico e narrativo, o tempo presente e o passado e a relação dialética entre literatura e história (CORRÊA, 1985 d, vol.Il, tomo l:99-105).

\section{$\underline{1923}$}

São Francisco de Sales é o discurso de Corrêa, pronunciado em 28 de dezembro de 1923, em comemoração ao 3ํㅡㄹ Centenário da morte do santo inspirador da ordem religiosa dos salesianos. Neste discurso, o escritor discute conceitos comparativos entre vocações literárias e vocações religiosas. O autor referencia seus posicionamentos críticos sobre estilo individual e estilo de época, bem como as distinções literárias entre sátira, ironia e espiritualidade, centrado nas figuras de Francisco Rabelais, o qual cognominou de "filósofo dos bobos"; Francisco Voltaire e Francisco de Sales (CORRÊA, 1985 b, vol. II, tomo I: 115-138). Através do escritor Rabelais, discute a sátira; através de Voltaire discute a ironia, o cinismo cético e elegante com que este discute o seu século; e com Sales discute a espiritualidade humana, glorificando o espírito, o caráter e o estilo particular de cada escritor. 


\section{4}

Falece o pai de Aquino Corrêa e o escritor escreve a carta pastoral À memória de meu pai, uma das pastorais mais belas entre as tantas que produziu. Os célebres versos escritos em carta a Pero Andrade de Caminha, como "Floresça, fale, cante, ouça-se e viva/ A portuguesa língua! E já onde for,/ Senhora vá de si, soberba e altiva" - do poeta português António Ferreira, que foi um defensor acérrimo do purismo da língua portuguesa, que os usou, exclusivamente, para condenar o hábito, que havia entre os escritores portugueses, de escreverem tanto em português, como em castelhano, servem de mote para o intelectual, através do discurso Sede Brasileiro, pontuar seu juízo crítico sobre mestiçagem racial e cultural e estabelecer, através do uso comum da língua portuguesa, o elemento de coesão para as nacionalidades (CORRÊA, 1985 b, vol.II, tomo I:139-152).

\section{$\underline{1926}$}

É eleito membro da Academia Brasileira de Letras, na vaga deixada por Lauro Müller. Assume a cadeira 34. Sua posse foi um acontecimento social ao qual compareceu o Presidente da República Washington Luís e todo o seu Ministério, bem como as figuras de maior destaque no mundo da cultura nacional. Por esta época publica o poemanarrativo Flor da Aleluia. (CORRÊA, 1985 b, vol. I, tomo II: 160-165)

\section{7}

Os discursos Os meus ideais literários e Mato Grosso na Academia Brasileira pronunciados, respectivamente, em maio, na festa oferecida pelo Centro Matogrossense de Letras, por motivo da eleição do autor para a Academia Brasileira de Letras, e em junho, em agradecimento pela eleição do primeiro mato-grossense para a Academia, definem o lugar de Aquino Corrêa nas discussões sobre a literatura brasileira escrita em Mato Grosso (CORRÊA, 1985 b, vol. II, tomo I: 233-246). Em 30 de novembro, há a sessão solene de posse de Aquino Corrêa, na Academia Brasileira de Letras. 


\section{8}

O discurso Castro Alves e os moços, pronunciado no dia 28 de março de 1928, em agradecimento ao Grêmio Literário Castro Alves, de Cuiabá, pela festa comemorativa da entrada de Aquino Corrêa para a Academia Brasileira, é o texto que, efetivamente, esboça os critérios que mais interessam à crítica quanto à elaboração da forma e da matéria literárias, ao uso da língua literária na expressão poética, na prosa-poética e na prosa, exemplificando tais posicionamentos com os escritores Castro Alves, Euclides da Cunha e Ruy Barbosa. A composição métrica, as metáforas, as hipérboles, as apóstrofes, as alegorias, as antíteses, enfim, os recursos lingüísticos que resultam uma elaboração textual a qual universaliza o poeta,

Por aí se vê que nem os gênios podem forrar-se, impunemente, aos esmeros da linguagem e aos estudos da língua. É que esta constitui matéria prima, indispensável a toda e qualquer concepção literária. Idéias por geniais que sejam, à semelhança de jóia preciosa em cravejamento reles de alquime, se deslustram e apagam, nas impurezas do dizer enxacoco e desgracioso (CORRÊA, 1985 d, v.II, tomo I: 257-284).

\section{7}

Mensagem aos homens de Letras é o discurso que foi proferido por Aquino Corrêa, na Academia Brasileira de Letras, no Rio de Janeiro, em 14 de janeiro de 1937, e que registra o pensamento crítico de Aquino Corrêa em relação à língua literária, distinguindo-se questões referentes à ortografia e à sintaxe, questões referentes à filologia e à estilística.

\section{8}

O discurso Te Deum Laudamus pronunciado em missa de ação de graças pelo I Centenário do Instituto Histórico e Geográfico Brasileiro, no Rio de Janeiro, em 21 de outubro, registra o pensamento crítico de Aquino Corrêa em relação à história e à literatura. Parafraseando uma passagem bíblica de Macabeus em defesa da verdade e do estilo, alega que a forma literária é de somenos importância, dado que o que se defende é um estilo perfeito, o qual, "assim como o vinho, torna-se mais agradável alternado com a água" ( CORRÊA, 1985 d, v.II, tomo I: 198). O escritor nomeia a 
religião, a língua e as tradições como elementos indispensáveis à existência da nacionalidade.Tal posicionamento crítico é reafirmado no discurso Gonçalves Dias, pronunciado na Academia Brasileira de Letras, no Rio de Janeiro, em 3 de novembro de 1938, em comemoração ao aniversário da morte do poeta.

\section{2}

Foram publicadas, sob a designação de Letras Pastorais, as Circulares Sacras, escritas entre 1922 e 1934. A princípio, estes documentos, que registram sermões e pregações escritos e proferidos por Aquino Corrêa, eram impressos e difundidos pela Arquidiocese de Cuiabá, em forma de opúsculos (folhetos).

\section{$\underline{1940}$}

Ano de publicação da terceira e última edição de Terra Natal. Em 20 de abril de 1940, em Cuiabá, na instalação do Grêmio Literário Dom Aquino Corrêa, o escritor pronuncia o discurso $A$ flor dum ex libris em que expressa a importância da intelectualidade feminina nos movimentos culturais do Mato Grosso, defende o cultivo de um estilo literário assentado no esmero da linguagem. E, em 24 de outubro do mesmo ano, através do discurso O Padre Vieira, o escritor reforça o seu posicionamento crítico em relação ao estilo literário assentado no esmero lingüístico.

\section{$\underline{1946}$}

No discurso Boas-vindas acadêmicas, pronunciado na Academia Mato-Grossense de Letras, ao recepcionar o acadêmico Luís Philippe Pereira Leite, em 8 de abril, Aquino Corrêa reforça o seu posicionamento crítico em relação à expressão literária assentada no esmero lingüístico, e à importância da aplicação da mente aos estudos das matérias clássicas, e nos contatos de leitura com obras da literatura clássica.

\section{$\underline{1947}$}

Publicam-se a obra Nova et vetera, considerada pelo poeta como "coletânea de poesias velhas e novas", e as Cartas Pastorais, escritas entre os anos de 1935 e 1944. 


\section{2}

Em 12 de junho de 1952, data em que se comemoravam o jubileu de ouro do religioso e o de prata do acadêmico, registra-se no discurso Dois Jubileus, proferido por Aquino Corrêa por ocasião do I Congresso Eucarístico de Mato Grosso, em Cuiabá, o que consideramos como um segundo ponto que nos dá a dimensão do pensamento crítico do escritor mato-grossense em relação ao dom de "fazer poemas" e à distinção necessária entre o poeta, o escritor e o religioso:

O fato é que lá pelos fins do século passado (XIX), freqüentava as aulas do Liceu Salesiano São Gonçalo, como faltavam aí os dois últimos anos do Curso Ginasial, tive que sair e continuar os estudos particularmente, e vi-me reduzido à condição de autodidata.Aqui foi que se deu a nova e misteriosa orientação, nas tendências intelectuais do futuro noviço salesiano:livre na escolha das matérias a estudar, entreguei-me, de corpo e alma, ao latim.Tivesse isso acontecido com a língua e a literatura vernáculas, ou qualquer das disciplinas, a que me afeiçoara nos primeiros anos do Ginásio, nada de estranho.O latim, porém, era então a minha grande ojeriza.Tal para mim a gramática latina.Desde as declinações, causara-me terror.Duas vezes a tinha começado, e duas vezes a deixava, com crescente enfado.De repente uma grande paixão pelo latim.Como explicála? Certo que não foi com fim de abraçar a carreira eclesiástica que me pus a estudá-lo.Muito outra fora a minha intenção: de todo em todo literária; não sei que desejo ardente de pôr-me em contacto direto com a poesia latina, especialmente os poemas de Virgílio.Mas conhecer assim de perto as musas pagãs, não se diria preparação lá muito favorável ao ingresso em noviciado ou seminários. Deus se encarregou do resto. Antes de tudo penso que 0 latim tenha dado seriedade às minhas pretensões humanísticas (CORRÊA, 1985 c, Vol. II. Tomo III: 285-288).

\section{6}

Em 22 de março, Aquino Corrêa falece em São Paulo e tem o corpo transladado para Cuiabá-MT, onde, como religioso, é enterrado na Catedral Metropolitana; como político, recebe as honras fúnebres de Chefe de Estado; e, como poeta e crítico literário, encontra-se imortal na cultura mato-grossense. 


\subsubsection{Motivações}

A propósito, em face à aproximação mais detalhada da vida e da obra de Aquino Corrêa, convém fazer algumas observações sobre os procedimentos metodológicos adotados e as motivações que ensejaram a escritura deste capítulo, pretendendo, com ele, deixar evidenciadas as fronteiras entre o homem comum, o religioso, o político, o poeta e o escritor.

A princípio, considerando os três pontos de vista que propõem Wellek e Warren (2003), que a obra de arte é o "seu criador", o reflexo de um "gênio" e o modo particular com que o escritor pensa o processo poético, realizamos os estudos literários sob o prisma biobibliográfico, por entendermos que este percurso nos possibilita traçar o perfil do escritor na fronteira entre o gesto criativo e o gesto teórico,, de modo a distinguir o discurso crítico de Aquino Corrêa em relação à sua própria obra, e os parâmetros pensados por ele para conceber a obra literária.

Aliados à concepção de estudos literários como uma ciência, adotar a biobibliografia como fonte exige que se filtre desta tão somente o que contemple o perfil de criatividade do escritor, procedimento que permite distinguir o plágio, a paráfrase e até mesmo a cópia de obras de outros artistas e chegar a uma avaliação crítica da temática e do estilo particular do escritor; ver na obra literária o reflexo da genialidade do seu autor subentende-se perceber o resultado positivo de um percurso formativo que leva em conta as relações de recepção e influência literárias, de modo que as obras sejam avaliadas como acréscimo positivo ao sistema literário e ao contexto cultural de onde estas emergiram.

Teoricamente apoiados em Wellek e Warren (2003), percebemos que o interesse intrínseco da biografia pode deslocar o centro de atenção para a personalidade do escritor e negligenciar o fato literário. Atentos a este tipo de negligência e diante dos equívocos que um estudo desta natureza pode suscitar, privilegiando os aspectos biográficos em detrimento do reflexo que estes dados podem suscitar na fortuna crítica do escritor, optamos por fazer a distinção da biografia como fonte de fornecimento de dados que podem acrescentar, a partir de Aquino Corrêa, aspectos precursores de teoria e crítica literária à história da literatura produzida em Mato Grosso. 
Neste enfoque inicial, tomamos a biografia como o gênero que lida com os problemas de apresentação cronológica, de seleção de acontecimentos, de discrição e objetividade na interpretação dos documentos, das reminiscências e das declarações autobiográficas. Assim, a biografia contribui para decidir aspectos que se relacionam, mais especificamente, às influências presentes na formação do escritor e o reflexo destas, tanto na obra de Aquino Corrêa, como na forma particular com que este pensava o poema, e a interferência destas (influências) no sistema cultural onde as obras se originaram.

Por lidar com fatos desta natureza, afastamo-nos de estudos especificamente literários neste primeiro capítulo e privilegiamos o caráter cronológico da biografia que, por não fazer nenhuma distinção entre o teólogo, o político, o escritor e o homem que não desempenha nenhum papel público, a biografia vai inserir-se como parte da historiografia literária do Mato Grosso e esclarecer determinados aspectos críticos da poesia produzida por Aquino Corrêa.

Os estudos biobibliográficos realizados orientaram-nos o encontro com o poeta, cujo desenvolvimento moral, intelectual, social e cultural, a carreira externa e a vida emocional foram reconstruídos e avaliados de acordo com padrões extraídos do sistema e dos códigos de ética vigentes e que sustentam a formação do escritor Francisco Tomás de Aquino Corrêa.

Os estudos centrados na análise minuciosa de dados referentes à vida e à produção escrita de Aquino Corrêa procuram filtrar e atualizar tais dados, de forma que eles funcionem como parâmetros para se pensar traços precursores de teoria e de crítica literárias na história da literatura produzida em Mato Grosso, no final do século XIX e início do século XX.

Esta atualização procura dar conta de apresentar um perfil da história da literatura mato-grossense, acrescido de juízos críticos remanescentes dos princípios estéticos do Classicismo, do Neoclassicismo, do Romantismo e do Parnasianismo, numa leitura que procura privilegiar 0 uso da língua literária como instrumento fundamental para a elaboração do objeto estético.

As características próprias do Romantismo como o subjetivismo, a liberdade de escolha de temas e de composição, os meios de expressão de sentimentos e de 
estados de alma, o predomínio da sensibilidade e da imaginação sobre a razão aliamse às regras de composição e estilo clássicos preconizadas pelo Classicismo e pelo Neoclassicismo para dar forma ao discurso crítico de Aquino Corrêa sobre a beleza literária subordinada à elaboração da matéria e da forma poéticas.

Sob este prisma, a dialética entre o clássico e o romântico explicita a forma de como vemos o escritor Aquino Corrêa, cujas particularidades que compõem o seu universo sociocultural se ajustam para dar forma a um fazer literário característico, em que a originalidade funciona como forma reveladora do princípio crítico fundamental de percepção da obra literária como produto do desenvolvimento de uma temática característica e de uma fina elaboração formal.

Por um lado, os dados biográficos de Francisco Tomás de Aquino Corrêa traduzem a ascensão do sujeito histórico inscrito em uma realidade, sintomaticamente, desfavorável ao crescimento sociocultural de qualquer cidadão que não estivesse filiado, diretamente, às classes política e econômica dominantes à época. E, por outro, estes dados atualizam os posicionamentos críticos do escritor presentes na sua escrita, filiando-o ora ao Classicismo, pela herança dos fatores humanistas, ora ao Romantismo, pelo subjetivismo e pela liberdade de expressão da matéria com a qual constrói os seus poemas, e por fim ao Parnasianismo, pelas considerações sistemáticas sobre a forma poética e a língua literária.

Assim, uma leitura mais atenta da biografia, dos poemas e dos discursos de Aquino Corrêa é reveladora de posicionamentos críticos do escritor sobre religião, literatura e temáticas características das suas obras. Citamos o caso da imagem da mulher sempre projetada na figura da Virgem Maria. O Padre Pedro Cometti ${ }^{6}$ é o autor do juízo crítico que melhor reflete esta presença feminina nos escritos do intelectual.

Dom Aquino conseguiu sublimar a falta da presença materna em sua vida com uma devoção filial, na acepção mais verdadeira do termo, à Virgem Maria.Nas poesias da adolescência e da velhice, nos discursos, nos sermões e nas Cartas Pastorais, ele canta a beleza, a santidade, o poder suplicante d'Aquela que preencheu sua sede de beleza, de virtude e de amor. (COMETTI, 1994:26)

\footnotetext{
${ }^{6}$ Fonte: COMETTI, Padre Pedro. Dom Aquino Corrêa, Arcebispo de Cuiabá:vida e obra.Obra editada em 1994, com o preparo de texto e revisão gráfica de Corsíndio Monteiro da Silva, sem identificação da editora responsável pela publicação.
} 
O poema A mim o céu! datado do ano de 1916, constante na abertura da obra Odes (CORRÊA, 1985 a v. I, tomo I: 49-51), é fonte reveladora dos questionamentos do artista diante da fugacidade das coisas do mundo, e reitera o caráter de efemeridade dos valores materiais como uma marca constante na temática do escritor. O poema registra a metáfora de um mundo em constante movimento de travessias e passagens para um plano superior à vida do mundo material: "A mim a vida que não passa nunca! A mim o céu!":

Do mundo passa a fugitiva imagem...

Passa do mundo o fugitivo espectro...

Do mundo passa o fugitivo sonho...

Passa do mundo a fugitiva cena...

Ir-se-á do mundo a fugitiva sombra...

A vós do mundo a fugitiva imagem.

O poema A mim o céu também é fonte para a releitura do verso de autoria feminina da Irmã Teresa do Menino Jesus ${ }^{7}$, designação canônica da francesa Marie Françoise Thérèse Martin, "Do mundo passou a fugitiva imagem...a mim o céu!"8 . Tal incursão localiza o intelectual no universo das referências à figura feminina no ambiente da formação religiosa e literária.

\subsection{Hipótese}

Sem lugar a dúvidas, esta concepção de bio(biblio)grafia proposta por Wellek e Warren (2003), que adotamos como uma abordagem metodológica para trazer Aquino Corrêa como precursor de crítica e de teoria literárias na história da literatura produzida em Mato Grosso, implica, como sugere Bakhtin (2000) nas partes III e IV, da sua

\footnotetext{
${ }^{7}$ A efemeridade foi um traço característico da vida da francesa Marie Françoise Thérèse Martin.Ficou órfã de mãe aos 4 anos de idade; a sua irmã Pauline que ela adotou como mãe entra repentinamente para o convento;aos 15 anos pede autorização ao Papa, em Roma para ingressar na Ordem da Carmelitas Descalças; aos 21 anos de idade adota a "Pequena Via" caminho pequeno e reto que conduz à santidade; e falece aos 24 anos de idade.

${ }^{8}$ Traduzido de "Du monde elle a passe la fugitive image...A moi le ciel!" - Souer Thérese de l'Enfant Jésus. (In CORRÊA, 1985 a, p 49).
} 
Estética da criação verbal, em que saibamos reconhecer e compreender o princípio plástico-pictural da criação artística verbal, nos termos em que

O corpo exterior do homem, suas fronteiras exteriores e seu mundo são uma coisa dada (no dado extra-estético da vida), necessária e inalienável ao dado existencial; por isso esses fatos exigem o direito de figurar na estética, exigem ser reproduzidos e fundamentados; é para isso que são empregados todos os meios de que a arte dispõe: cores, linhas, volumes, palavras, sons. $\mathrm{Na}$ medida em que o artista lida com a existência do homem e com o seu mundo, lida também com os seus dados espaciais, com suas fronteiras exteriores e, fornece uma transposição estética dessa existência, precisa também transpor a exterioridade do homem em função do tipo de material que dispõe (BAKHTIN, 2000:109-110).

Assim, os aspectos cronológicos que privilegiamos na biobibliografia de Aquino Corrêa nos aproximam do princípio axiológico bakhtiniano, segundo o qual "o homem, na arte, é um homem em sua integridade", é corpo e é alma, é forma e é matéria.

Tal é o procedimento investigativo subjacente aos postulados teóricos de Wellek e Warren (2003) e de Bakhtin (2000) que, sem descurar da relação entre a vida e a obra do escritor, e apoiando-nos na sua biobibliografia, tratamos de filtrar diversas orientações teóricas e críticas, as quais articuladas entre si desempenham o papel de orientar a crítica, os críticos, os estudiosos e os pesquisadores na formulação de taxionomias que, mais do que serem empregadas na execução da obra literária, também sejam capazes de descrevê-la.

O termo "acontecimento" utilizado por Bakhtin (2000:122) mais do que uma designação com a qual identificamos e explicamos "o caráter de acontecimento da vida de uma dada pessoa", disponibiliza-nos, também, um conceito para o todo temporal e espacial já concluído da vida exterior e da vida interior do homem. Assim, concluímos que o que nos interessa não é dispor de um material completo sobre a vida ou de todos os fatos da biografia de Aquino Corrêa, mas dispor de uma abordagem conceitual que nos permita dar forma estética ao material que o caráter de acontecimento da vida do escritor pode fornecer para a arte.

Tendo em conta este aspecto, e considerando o fato de operarmos com a biobibliografia no âmbito da investigação para, através dela filtrarmos aspectos que 
referenciam princípios de crítica e de teoria literária, o acontecimento da vida interna que figura como um dado conceitual só nos é revelado através da memória.

Assim, a memória, neste sentido, vai diferir substancialmente da lembrança. Essa memória é produtiva e atualiza a vida de Aquino Corrêa e seu conteúdo de uma forma diferente, acrescida de valores conceituais.

O percurso cronológico da vida do escritor fornece um conteúdo que, através da memória, suscita uma atividade geradora de formas de pensar o acontecimento de sua vida, cujo acabamento final, proposto através da compreensão, torna possível pensar os parâmetros e princípios críticos e teóricos com que o escritor pensava a literatura.

Vista por este ângulo, a vida do escritor mato-grossense não se escoou com sua morte, ocorrida em 1956, sua vida adquiriu mobilidade e se encontra presentificada nos acontecimentos culturais que o inscrevem numa atualidade de leitura, neste caso, o sujeito social sobrevive independente de fronteiras que o possam circunscrever em tempo e espaço definidos.

A linguagem concretiza estes acontecimentos, e as fronteiras temporais pelo fato de serem um recurso de registro de ordem biográfica, instauram os valores que, na realidade, sobrevivem na vida acabada do outro. Assim, o autor, o escritor, o crítico e o teórico adquirem dimensão de vida no interior de cada escrita.

O diálogo silencioso que se registra entre a vida e a morte sustenta o jogo entre a atividade do $e u$, enquanto vida em ação, construção de conceitos e identidade, e a inércia da morte, que estabiliza as ações do eu e o coloca sob o ponto de leitura de análise-crítica e de interpretação da representação do outro, no interior de um dado sistema.

É neste entrecruzamento que os contatos e valores se estabelecem e passam a ser "acontecimentos" que só podem ser dimensionados pelos olhos do pesquisador.

A memória, no sentido de ser "a chave de ouro que assegura o acabamento estético do outro" (BAKHTIN, 2000:122), promove a atualização do acontecimento da vida, gerando mensagens elaboradas, ou seja, mensagens estéticas, que se configuram nos textos dos diversos poemas do escritor.

Nesta perspectiva, é necessário distinguir teoricamente memória e lembrança, conforme os termos tratados por Ecléa Bosi, na obra Memória e sociedade: lembranças 
dos velhos (1994: 81), tendo a memória uma função social e um aspecto mítico, e a lembrança, funcionando para fazer o deslocamento do interesse despertado pela memória e provocar outras reflexões sobre o que foi vivido.

Este movimento de atualização dos acontecimentos da vida exige um espírito desperto, capaz de "reconhecer as lembranças e opô-las às imagens de agora" (Op. Cit. p. 81). Desta forma, a memória, na função social, pressupõe uma inteligência do presente capaz de refletir teoricamente as relações dos acontecimentos do ontem nas dimensões atuais. Sob o aspecto mítico, a memória faz cair a barreira que separa o presente do passado, lança uma ponte sobre o mundo dos vivos, transformando-se na "viagem que o ser vivo faz ao país dos mortos para aprender a ver o que quer saber" (Op. Cit. p. 89).

Estas mensagens estéticas atualizadas figuram como produto final de uma elaboração conceitual tanto do autor como do leitor, e quando vistas sob o ângulo semiótico resultam em unidades culturais, que são definidas, por Eco $(2001)^{9}$, como unidades semânticas inseridas num sistema, onde adquirem valor metalingüístico e são traduzidas como "unidades interculturais representadas através de símbolos lingüísticos" (ECO, 2001: 16).

Estes símbolos lingüísticos são, efetivamente, unidades lexicais, portanto, significativas ao sistema literário. Estas unidades geram mensagens estéticas assentadas no discurso literário, que é, por excelência, um discurso plurissignificativo, e sempre sujeito à reformulação constante do conteúdo.

Esta reformulação é produto de leituras constantes, e ocorre no nível de interpretação do significante, gerando sempre um novo posicionamento, um ponto de vista diferente, que se transforma em uma nova unidade cultural, suscetível de outras novas reformulações que esvaziam a discussão improdutiva sobre o efeito paralisante da palavra escrita (ECO, 2001:21).

Assim, as unidades lexicais mínimas, as marcas gramaticais de organização do conteúdo registram em textos, variados aspectos semânticos que individuam no seu interior um autor, e, conseqüentemente, expõem a sua ideologia.

${ }^{9}$ ECO, Humberto. Estética:as formas do conteúdo.São Paulo:Perspectiva, 2001. 
Ancorados no princípio de que os variados aspectos semânticos individuam e expõem a ideologia do autor, fazemos a distinção entre o texto literário e o discurso literário, apoiando-nos teoricamente no que propõe Maingueneau $(1996: 18)^{10}$, segundo o qual, o discurso literário, assim como a literatura,

aparece como uma instituição, com seus rituais enunciativos dos quais os gêneros são a manifestação mais evidente.É dentro dessa instituição que uma égloga ou uma comédia adquirem sentido e, mais amplamente, que a comunicação literária se estabelece de maneira apropriada.Com isso, a pragmática desenvolve uma concepção de literatura diferente da concepção imposta pelo Romantismo, que privilegiava "a visão pessoal" do autor (ou de um sujeito coletivo) e relegava a segundo plano os rituais discursivos da instituição literária (MAINGUENEAU, 1996:18).

Tendo em conta estes aspectos que consideram a princípio o texto, e, conseqüentemente, o discurso literário, ambos a operar no âmbito da investigação literária, está consagrado pelos estudos crítico-literários em geral, que

A arte, e, portanto, a literatura, é uma transposição do real para o ilusório por meio de uma estilização formal, que propõe um tipo arbitrário de ordem para as coisas, os seres, os sentimentos. Nela se combinam um elemento de vinculação à realidade natural ou social, e um elemento de manipulação técnica, indispensável à sua configuração, e implicando uma atitude de gratuidade.Gratuidade tanto do criador, no momento de conceber e executar, quanto do receptor, no momento de sentir e apreciar (Antonio Candido, 2000:53) ${ }^{11}$.

O conteúdo ideológico, que é registrado através de unidades gramaticais de estruturação do texto literário, situa o autor em um momento sempre presente, resultado do jogo constante de articulação de fronteiras entre o texto e o contexto, de onde ele se originou; entre o passado e o presente, entre o local e o universal, o transitório e o permanente, o particular e o geral devidamente tecidos na carne de qualquer literatura que vale alguma coisa (CANDIDO, 2003:52).

\footnotetext{
10 MAINGUENEAU, Dominique. Pragmática para o discurso literário.Trad.Marina Appenzeller.Ver. da trad. Eduardo Brandão.São Paulo:Martins Fontes, 1996.(Coleção Leitura e Crítica).

${ }^{11}$ CANDIDO, Antonio. Literatura e sociedade:estudos de teoria e história literária. 8.ed. -São Paulo:T. A . Queiroz Editor, 2000.
} 


\title{
1.3 As interfaces de Francisco Tomás de Aquino Corrêa
}

Para compreendermos o traçado deste mundo labiríntico, expressão que tomamos emprestada do crítico Abdala Júnior (2003:28) ${ }^{12}$, para expressar uma obra literária concebida como um produto cultural misto de imaginação e técnica, é necessário dimensionar a sua composição através da articulação de individualidades que representam, de um lado, a matéria, a imaginação criativa de um autor e, de outro lado, a forma, a técnica, entendida sob o ângulo dos artefatos técnicos que o escritor dispõe para elaboração do objeto estético.

O sistema literário se compõe nas individualidades duplamente articuladas através da imaginação que se configura no vôo libertário de atores sociais, e na técnica entendida sob o ângulo da elaboração do objeto estético. Esta articulação assinala as formas mediadoras que um autor dispõe para dar a significação e a dimensão necessárias para que o objeto estético, sob o ângulo dos estudos científicos, adquira valor, no interior de um sistema literário. Neste ângulo, Antonio Candido considera que a obra depende estritamente do artista e das condições sociais que determinam a sua posição. Ao artista relacionam-se os aspectos estruturais da obra, propriamente ditos;

\begin{abstract}
quanto à obra, focalizemos o influxo exercido pelos valores sociais, ideologias e sistema de comunicação, que nela se transmudam em conteúdo e forma, discerníveis apenas logicamente, pois na realidade decorrem do impulso criador como unidade inseparável.Aceita, porém, a divisão, lembremos que os valores e ideologias contribuem principalmente para o conteúdo, enquanto as modalidades de comunicação influem mais na forma (CANDIDO, 2000:30).
\end{abstract}

Neste propósito de busca de considerações sobre teoria e crítica literárias em Mato Grosso, efetuamos o trabalho de recolha de dados na edição especial da obra de Aquino Corrêa, intitulada Dom Francisco de Aquino Corrêa: Obra Comemorativa do Centenário de Nascimento do Autor.

\footnotetext{
${ }^{12}$ ABDALA JUNIOR, Benjamin. Viajantes e Viagens. In: De Vôos e llhas:Literatura e Comunitarismo.São Paulo:Ateliê Editorial, 2003, p.13-62(texto).
} 
Esta editoração especial, resultado do esforço conjunto da Academia MatoGrossense de Letras, do Instituto Histórico e Geográfico do Mato Grosso e do Senado Federal, que, em 1985, tornaram possível esta compilação, está composta de oito volumes. Em três volumes, Odes, Terra Natal e Nova et Vetera, registra-se a obra poética; sob a rubrica de Discursos, também em três volumes, registram-se os oitenta e cinco textos de discursos de autoria do intelectual, que dimensionam o lugar do escritor, cujas produções têm como escopo a apresentação de idéias críticas, morais, filosóficas e teóricas, referentes a diversas formações culturais do seu Estado; e, em dois volumes intitulados Pastorais, foram editadas as cartas pastorais responsáveis pela identidade discursiva do religioso.

$\mathrm{Na}$ atualidade em que estes estudos se realizam, lança-se um olhar além das fronteiras do tempo cronológico para se perceber uma peculiaridade do sistema literário que caracteriza a literatura brasileira produzida em Mato Grosso, formada a partir da elaboração do objeto estético para a qual entram em concorrência princípios centrados na religião, na nacionalidade e na autoridade dos mestres antigos (REBELO, $1980: 116)^{13}$

\subsection{Vozes da tradição clássica em Aquino Corrêa}

Uma visão mais detalhada da produção poética de Aquino Corrêa publicada em Odes, Terra Natal e Nova et Vetera, e da produção oratória, publicada sob o título de Discursos, aproxima-nos do universo da poesia e da prosa neolatinas. Estas produções refletem a formação intelectual de Aquino Corrêa enraizada no Humanismo, traduzido como o movimento cultural que esteve a par do estudo e da imitação dos clássicos greco-latinos e fez do homem o objeto do conhecimento, reivindicando para ele uma posição de importância no contexto do universo, sem, contudo, negar o valor supremo de Deus ${ }^{14}$.

Apoiados nos estudos realizados por Luís de Sousa Rebelo (1980:115), sobre a presença da tradição clássica na literatura portuguesa, afirmamos que na formação das

\footnotetext{
${ }^{13}$ REBELO, Luís de Sousa.A tradição clássica na literatura portuguesa.Lisboa: Livros Horizonte, 1980.

${ }^{14}$ Humanismo.Fonte http://universoliterario.vilabol.uol.com.br/humanismo.html, página 2 de 4 . Acesso em 11/09/06.
} 
literaturas de língua portuguesa, tanto os poemas quanto os textos escritos em prosa apresentam-se zelosos dos cânones e da forma vernácula dos escritores de Roma. Esta constatação evidencia uma literatura plenamente assentada no movimento do Humanismo, traduzindo uma concepção sociológica da literatura, e um compromisso entre história, sociedade e literatura.

Ao adotarmos esta concepção, enveredamos pelos caminhos apontados por Antonio Candido (2000:169), no ensaio Estrutura Literária e Função Histórica, sobre a obra Caramuru, de Frei de Santa Rita Durão, que estabelece a função histórica ou social de uma obra, sempre dependente da sua estrutura literária. Sob este ângulo, as obras de Aquino Corrêa refletem, em sua organização formal, as representações simbólicas condicionadas tanto ao ambiente social, em que a obra foi escrita, como ao processo formativo que aponta para a filiação genérica do escritor.

Ora, com uma formação, predominantemente, alicerçada em valores clássicos, numa perspectiva que procura evidenciar os valores suscitados pelas obras do escritor para a posteridade, inferimos que as variações históricas da função das obras de Aquino Corrêa, no interior de um sistema literário, são determinadas pelas estruturas formais esteticamente invariáveis que elas apresentam.

Corroborando com este juízo crítico, Antonio Candido esclarece que "em face da ordem formal que o autor estabeleceu para a sua matéria, as circunstâncias vão propiciando maneiras diferentes de interpretar, que constituem o destino da obra no tempo" (CANDIDO, 2000:169).

E neste sentido, a filiação de Aquino Corrêa a valores que traduzem o acúmulo de referências a obras-primas da Antigüidade, remete-nos aos princípios teóricos de Guillén (1985:18), na assertiva de que, nos estudos comparatistas, o trabalho de percepção e elaboração do objeto estético implica certas dimensões comuns a outras áreas de estudos, e que diretamente referenciam contatos referentes à história e à dimensão filológica, porque são estas que possibilitam ao escritor e ao leitor familiarizarem-se com o escrito em sua língua materna, além de que, é o próprio idioma que lhes oferece o mais intenso acesso possível à emoção estética e à apreensão do que é ou não é literatura. 
Como se pode notar, estes posicionamentos críticos começam por considerar processos interdependentes de formação cultural, isto é, as experiências criam um sistema múltiplo de trocas sucessivas e de deslocamentos entre as experiências culturais do escritor e do leitor aproximadas pelas raízes lingüísticas.

Trata-se de uma perspectiva aceitável, visto que oferece a vantagem, como sugere o crítico literário Abdala Júnior (2003:103), de se perceber que na constituição do macrossistema das literaturas de língua portuguesa, há uma aproximação de sistemas literários nacionais que se alimentam de um passado comum e do diverso que caracteriza cada sistema em particular.

Subjacente, reconhecemos a base necessária para entender o ponto de vista de Aquino Corrêa que propõe traçar as linhas gerais para constituir uma consciência literária perpassando pelos caminhos da história geral da literatura.

A trajetória literária de Aquino Corrêa, assentada na defesa da pureza do idioma, cria uma visão de língua literária que possui normas próprias para o seu uso, e instaura, para o domínio dos estudos literários, os critérios necessários para o uso da língua na sua modalidade literária.

Este posicionamento afirma a importância do espírito crítico na análise de pormenores textuais, que se tornam marcas reveladoras do contexto sociocultural que possibilitou a criação da obra de arte.

Sustentados pelo raciocínio de Antonio Candido (1993), perseguimos a hipótese de que nos estudos literários se estabelece uma relação de intimidade entre escritor e leitor, visto que "ao descrevermos os sentimentos e as idéias de um determinado período literário, nós elaboramos mais um ponto de vista que existe em nós, segundo a perspectiva da atualidade deste ponto de vista, na nossa época, do que nos indivíduos que o integraram" (CANDIDO, 1993:285).

Neste sentido, é necessário o esforço para compreendermos e determinarmos o que os escritores dizem e como fazem para dizer, e exprimir as idéias que o estudioso, num movimento dinâmico, que se alimenta sempre de fatos e idéias de outros tempos, de outros atores e de outros momentos, trata de sintetizar, interpretar e atualizar. 


\subsection{Aquino Corrêa e os gêneros literários}

Em relação aos critérios que adotamos para pensar a literatura produzida em Mato Grosso, segundo os posicionamentos crítico-teóricos de Aquino Corrêa, percebemos que as obras do escritor têm um compromisso com o fazer literário e a evolução deste fazer subsidiando mudanças que se voltam tanto para o refinamento dos processos de elaboração do objeto estético, ancorados na língua literária, como para a escolha do material temático, na constituição do conteúdo poético e a sua conseqüente avaliação crítica.

As mais diversas fontes referenciados por Aquino Corrêa, tanto em seus poemas quanto em seus discursos, não demonstram subserviência ao modelo, ou uma forma de restrição do espaço discursivo do escritor, pelo contrário, propõem a leitura dos antigos como forma recorrente para se perceber os contactos e fortalecer as fronteiras que identificam as influências que não se limitam, a épocas estanques, nem ao gosto, nem à sensibilidade de percepção do novo.

Em Poética e em Discursos, Aquino Corrêa exterioriza posicionamentos críticos situados na esfera de um gosto erudito que se traduz como comprometimento na elaboração do objeto novo. A poesia e a prosa não prescindem das raízes de identidade genérica, traduzidas em formas literárias, que atualizam valores conceituais à medida que se instalam no interior de um sistema literário, e passam a constituir dados, que, pela ótica do pesquisador, sustentam uma identidade peculiar.

Os desdobramentos dos gêneros literários épico, lírico e dramático, que trazem a chancela e a autoridade dos mestres antigos, adquirem vitalidade nas formas atualizadas pelas exigências tanto externas, referentes a um mercado consumidor de literatura, quanto internas, por justificarem a evolução dos estudos científicos da literatura.

Assim é que, orientados por Rebelo (Op. cit. 1980:100), na extensão de sentido do movimento literário neoclássico, entendido como, "o movimento literário, derivado do Iluminismo, que visa à reabilitação e à restauração dos gêneros literários, das formas, das técnicas e da expressão clássica", vemos o Neoclassicismo influenciando 
fortemente a obra de Aquino Corrêa em dois setores capitais: o da criação literária e o da doutrinação estética.

$\mathrm{Na}$ análise da escrita dos textos de Aquino Corrêa, no que diz respeito aos gêneros literários, interessam-nos os aspectos que se referem exclusivamente ao gênero lírico.

Neste sentido, adotamos a visão de Aguiar e Silva (2000:340), que coloca o gênero lírico sob o ângulo conceitual e estrutural, centrado no domínio de conceitos como o de tradição e mudança literária; imitação e originalidade; modelos, regras e liberdade criadora, e de correlação entre estruturas estilístico-formais e estruturas semânticas e temáticas; entre classe de textos e classe de leitores, para avaliar a influência e o lugar de onde o escritor sustenta seu ponto de vista.

Ora, se os acontecimentos, em fronteiras móveis, se formam e se transformam resultantes de uma elaboração, a tradição se traduz exatamente nos pontos de contatos situados, não no interior de uma época, mas na fronteira de duas épocas, no lugar onde se concentram os fundamentos da vida de um escritor, no seio de uma dada sociedade, essenciais para a existência naquele e daquele momento, e "são exatamente estes fundamentos da vida que estão mudando e compete ao homem mudar junto com eles" (BAKHTIN, 2000:240).

As mudanças não implicam o anulamento dos acontecimentos passados. Pelo contrário, as obras de Aquino Corrêa são depositárias de acontecimentos que sustentam a formação histórica do homem e da sociedade em que ele se insere. Situadas nestas regiões de fronteira, onde se assentam os motivos que geraram os acontecimentos sociais, as obras se traduzem sempre em algo arbitrárias, localizadas entre o "gesto criativo" e o "gesto teórico"15.

Um estudo detalhado da morfologia da obra de Aquino Corrêa reflete simultaneamente as fronteiras que resguardam a formação sociocultural do poeta e os indicativos de mudanças que requerem, do escritor, posicionamentos significativos que se traduzem em respostas presentes na escrita do poema.

\footnotetext{
${ }^{15}$ Fonte: MELO E CASTRO, Ernesto M. Poesia/Transpoesia/Repoesia:alguns tópicos atuais nas poesias brasileira e portuguesa.Revista USP.São Paulo:36, 116-127.Dezembro/Fevereiro, 1997-98.
} 
Segundo Mello e Castro (2000: 119), escrever e ler, seja por quais meios, suportes e códigos, são os únicos instrumentos de pesquisa e de resistência de que dispomos para nos localizar neste 'espaço-tempo de transformação' que leva em conta as obras como depositárias de tais transformações.

Em relação aos gêneros literários, não nos interessa perceber a obra como representação do diverso multiplicado em diversas formas de apresentação, interessanos privilegiar os fatores técnico-semânticos de produção e recepção da obra artística, concebendo a análise dos poemas na sua diversidade empírica e classificando-os em função dos seus caracteres formais e semânticos.

Assim, num posicionamento que se afigura dogmático, o gênero literário é concebido em função dos fatores formais e temáticos presentes no texto, em conformidade a uma "tradição formal e uma determinada relação, que se estabelecem com os receptores" (AGUIAR E SILVA, 2000: 346-347).

Assim, o poeta deve adotar, em conformidade com os temas tratados, normas convenientes, subordinadas a modalidades métricas e estilísticas. A infração desta norma, que em termos de gramática do texto poderíamos considerar como reguladora da coerência textual, desqualifica radicalmente o poeta.

Em particular, no caso de Aquino Corrêa, verifica-se que o escritor segue e defende esta norma que se aplica à existência da tradição clássica da poesia. Esta norma é traduzida em posicionamentos críticos onde "os poetas, os criadores literários participam no debate e submetem as próprias composições ao juízo dos confrades" (REBELO, 1980:101).

Sob o ponto de vista em que colocamos Aquino Corrêa, no entrecruzamento das discussões sobre gênero literário, percebemos, nos textos de Poética e Discursos, a preocupação em submeter a uma larga revisão, os valores estéticos e as questões referentes aos gêneros e ao estilo literários, de forma a contribuir para uma teorização da literatura produzida em Mato Grosso.

Neste sentido, a produção poética, zelosa dos cânones e da forma vernácula, traduz uma emulação para o artista, no plano da qualidade literária e da beleza formal. Porém, para a sensibilidade moderna e o caráter de atualização crítico-teórica, a que 
nos propusemos, esta poesia se apresenta atualizada, porque está nutrida de valores culturais resultantes da experiência humana.

Através desta investigação biobibliográfica, traduzimos uma identidade temática e formal dos textos de Aquino Corrêa, possibilitando a aproximação entre o contemporâneo e o que resta de vivo dos antigos na produção literária do escritor.

Promovemos uma atualização de dados que não se apresentam como concluídos e finalizadores de um processo, pelo contrário, estão sempre inacabados e sujeitos a novas leituras, interpretações e a novos posicionamentos críticos.

Nas primeiras décadas do século XX, Aquino Corrêa afigura-se como precursor de alguns conceitos literários e de uma visão de literatura que não se restringe a espaço, época ou escola literária, mas a uma literatura resultante de diálogos. 


\section{CAPÍTULO 2}

\section{A poesia em Mato Grosso a partir de Aquino Corrêa}

Poeta é o tipo de homem que faz versos, é dotado de um senso especial em relação às palavras, sabe explorálas por meio de uma técnica adequada a extrair delas o máximo de eficácia. Só a tais homens ocorre o fenômeno chamado inspiração, espécie de força interior que o leva para certos caminhos da expressão ( ANTONIO CANDIDO, 2006:104). 


\section{1 "Poema" e não "poesia": da natureza universal do texto lírico}

Não ouso discutir com quem medita em um só livro! Irá nisso talvez alguma hipérbole; mas é certo que, em matéria de leitura para a formação intelectual, a norma será sempre esta: não ler muitas coisas, mas escolher o ótimo, que é sempre pouco, e ler muito esse pouco (CORRÊA, 1985 d, v. II, tomo I: 134).

Uma leitura atenta às obras Odes, Terra Natal, Nova et Vetera e Discursos faz saltar à vista um aspecto particularmente interessante do escritor mato-grossense Aquino Corrêa: a preocupação em definir os lugares ocupados pelo artista, diante da complexa riqueza de tendências estéticas que surgiam no início de século XX.

Segundo Aquino Corrêa (1985), nesse contexto finissecular, marcado pela complexidade de diversas dominantes literárias, o artista deve se imbuir de um espírito crítico cada vez mais claro e definido, como condição essencial ao exercício da liberdade de expressão, marca fundamental da arte literária contemporânea.

Por um lado, esta preocupação se traduz no julgamento que o poeta faz da sua produção literária em particular, por outro, traça os parâmetros sobre os quais o escritor julga assentar a arte de fazer poesia.

Atraídos pela conceituação e a julgar o rigor dos conceitos disponibilizados por Aquino Corrêa no interior de sua escrita, cotejamos uma integração com as diversas orientações teóricas, críticas e metodológicas propostas por Antonio Candido, em $O$ estudo analítico do poema (2006), para quem, "os conceitos lucram em ser apresentados como instrumentos de prática imediata, isto é, de análise" (CANDIDO, 2006: 8).

As definições de 'poeta' e 'inspiração', propostas por Antonio Candido (2006), no texto da epígrafe deste capítulo, como sendo o poeta, "o tipo de homem que faz versos", e a inspiração, como sendo uma "espécie de força interior que leva o poeta para certos caminhos da expressão", constituem o mote para o desenvolvimento deste capítulo, na medida em que apontam as formas que, no âmbito dos estudos literários, convergem para a produção do poema no universo expressivo da poesia, tratando, portanto, do poeta e sua relação com as palavras. 
O estudo do texto lírico sob este ângulo exige o domínio de alguns conceitos de ordem formal que se tornam fundamentais para orientar a atividade dos estudiosos que se dedicam aos estudos crítico-literários, bem como leva-nos a compreender 0 postulado maior de Aquino Corrêa assentado numa matriz de gosto neoclássico de percepção da literatura obediente a um fim ético e moral, devendo a forma manter-se em perfeita harmonia de valores verbais e equilíbrio entre a razão e o sentimento.

A princípio, o poema aqui é tratado como produto concreto da poesia, como unidade textual que dá forma ao ato criador, além de nortear, limitar e concentrar a atividade dos estudiosos e críticos literários.

Esta abordagem parte do pressuposto de que no âmbito de elaboração do objeto estético concorrem, simultaneamente, elementos tanto de ordem formal como de ordem expressiva, levando em conta o conceito de poesia como "categoria privilegiada de criação espiritual e forma suprema de atividade criadora da palavra" (CANDIDO, 2006:19).

\subsection{Percursos da crítica: comentário, análise e interpretação}

Defendendo o princípio de que, para a crítica literária moderna, a sensibilidade artística é requisito fundamental tanto para o poeta, na elaboração do poema, como para os estudiosos que se dedicam aos estudos analíticos do mesmo, ocupamo-nos, neste capítulo, dos aspectos referentes à interpretação científica ou sistemática da criação da obra de arte, por entendermos que é esta que, efetivamente, garante a verdadeira apreensão do poema.

Nesta linha teórica, em que os conceitos funcionam como princípios necessários para o exercício da crítica literária, levamos em consideração a sutileza da distinção entre "comentário" e "interpretação literária" nos termos manifestados por Antonio Candido:

Num texto literário há essencialmente um aspecto que é tradução de sentido e outro que é tradução do seu conteúdo humano, da mensagem por meio da qual um escritor se exprime, exprimindo uma visão do mundo e do homem. O estudo do texto importa em considerá-lo da maneira mais íntegra possível, como 
comunicação, mas ao mesmo tempo, e, sobretudo, como expressão. $O$ que o artista tem a comunicar, ele o faz à medida que se exprime. A expressão é o aspecto fundamental da arte e, portanto, da literatura.O comentário é uma espécie de tradução, feita previamente à interpretação, inseparável dela essencialmente, mas teoricamente podendo consistir numa operação separada (CANDIDO, 2006:27).

Para o crítico, a poesia se concretiza através da elaboração de uma matéria e de uma forma a que se convencionou denominar de poema, o qual comporta unidades expressivas que, ao mesmo tempo em que dão corpo à poesia, orientam, limitam e concentram as atividades nos estudos críticos.

Em se tratando de crítica literária, é fundamental evidenciar as relações de pertinência entre análise e interpretação e entre comentário e interpretação literária destas unidades expressivas, visto que "a crítica moderna tende a várias formas de interpretação que levam em conta a estrutura interna do poema contra a tradição ossificada do comentário erudito, que bania o requisito da sensibilidade, e, portanto, a verdadeira apreensão do poema" (CANDIDO, 2006:24).

Perseguindo estas orientações advindas da conceituação de cada um destes pontos, estabelecemos a necessidade do comentário, da interpretação e da análise como sendo os três momentos sobre os quais se assenta a crítica literária consciente.

A princípio, o comentário precede a interpretação e funciona como o esclarecimento objetivo dos elementos textuais necessários ao entendimento adequado do poema. Segundo Antonio Candido (2006), "para os estudiosos de mentalidade positiva", o comentário é algo "universitariamente" respeitável, porque se dirige, no texto, a aspectos verificáveis de cunho histórico, lingüístico, biográfico, etc, sendo, portanto, condição prévia para se realizar a análise ou o estudo crítico do poema, e, posteriormente, aplicar-lhe a interpretação que funciona como "reforço" para se compreender a natureza íntima da poesia.

Nesta ótica, a interpretação, no dizer de Antonio Candido, funciona como uma penetração compreensiva através de uma linguagem adequada à matéria do poema, à estrutura íntima do texto e às normas estruturais peculiares à forma adotada pelo poeta, segundo as quais "uma obra literária se processa, se divide e se constitui de novo como unidade" (2006:28). 
Assentados no princípio de que a investigação sobre o poema é uma operação feita em duas etapas simultâneas, que compreende o comentário analítico e a análise interpretativa, intimamente ligados, mas que podem se dissociar, afirmamos que no cenário da literatura produzida em Mato Grosso, no período focalizado para a realização desta tese, os estudos críticos referentes à poesia carecem de trabalhos de cunho analítico que realmente atendam a esta exigência da crítica literária.

No interior destas formulações, que prevêem o estudo analítico do poema como condição essencial para se estabelecer juízos críticos de valoração das obras de determinados escritores, como "expressão da realidade local e, ao mesmo tempo, elemento positivo na construção do sistema literário nacional", percebemos o lugar discursivo de Aquino Corrêa, no período em que realizamos os estudos aqui apresentados, tanto como o "tipo de homem que faz versos" quanto do ângulo do estudioso que é "dotado de um senso especial em relação às palavras, sabe explorálas por meio de uma técnica adequada a extrair delas o máximo de eficácia" (CANDIDO, 1993:25).

Nesta abordagem, feita sob a égide da crítica literária, tomamos como ponto de partida, para elaborar a síntese do comportamento crítico de Aquino Corrêa em relação à obra literária, o texto de abertura de Odes (CORRÊA, 1985 a, v.l, tomo I: 21-45) intitulado "Prelúdio", no qual se encontram formulados os juízos críticos sobre questões relacionadas à poesia, os quais convergem para o que Candido (2006) propõe em relação ao estudo analítico do poema.

Mediante o aparato teórico proposto por Candido (2006), adotamos o princípio de que a poesia não é o poema e nem se confunde com o verso, muito menos com o verso metrificado, e que após o advento das correntes pós-simbolistas, a poesia excedeu-se, ultrapassou os chamados gêneros poéticos, realizando-se também na prosa de ficção.

O tratamento dado à poesia e ao poema, sob este ângulo, possibilita criar um conceito para poema que se aproxima do que Aguiar e Silva (2000: 582) denominou como "texto lírico", constituindo-se o lugar onde o conteúdo poético ganha uma forma e se estabelece a "relação de implicação" entre o eu do "autor textual" e o eu do "autor empírico". 
Assim, o poema é o lugar onde se verifica o empenho total do poeta para realizar a sua revelação, ocorrida "graças à fulguração da palavra, na emoção, nas vozes íntimas, na meditação, na ressonância mítica e simbólica" (AGUIAR E SILVA, 2000:582), através de uma linguagem que suscita a exteriorização de uma subjetividade característica.

No essencial, essa é, também, a postura de Aquino Corrêa, que acaba preconizando que os versos traduzem, numa espécie de roupagem, as "inspirações":

Sonhos da infância, por onde, no azul diáfano da inocência, perpassam revoadas luminosas de anjos, e, mais formosa que todos eles, a visão sorridente de minha mãe...Frêmitos misteriosos do coração adolescente que, desabrochando, incônscio, para o Infinito, borboleteia à flor de todos os ideais e, por entre os encantos de luxuriante Pátria, busca em vão repouso na criação inteira...Transportes deliciosos de uma alma de noviço, de sacerdote e de Bispo para quem Deus é o Ideal dos ideais, a Poesia infinita, pela qual tudo é belo, e sem a qual tudo é nada...Eis aí as inspirações latentes, mas latejantes, (...) o espírito que vivifica a letra dos humildes versos (...) (1985 a: 21).

Para Aguiar e Silva (2000: 583), "neste mergulho do homem nas suas águas mais silenciadas, o que vem à tona é tanto uma singularidade como uma pluralidade", que traduzem, para o interior de um sistema literário, uma espécie de "tomada de consciência" ${ }^{\prime 16}$ do poeta que revela, através da sua obra, determinados caracteres referenciais e paradigmáticos que são preservados através do texto literário.

Esta ótica de Aguiar e Silva (2000:582) converge para o princípio filosófico hegeliano, segundo o qual, o que forma o conteúdo de um poema não é o desenvolvimento de uma ação objetiva, prescritiva, que se alarga em toda a sua riqueza até os limites do mundo, mas uma singularidade do sujeito individual, do autor que se revela através do texto.

Por conseguinte, esta revelação se estende ao contexto, às situações e aos objetos particulares que circundam o autor, revelando a maneira, segundo a qual, a alma, com seus juízos subjetivos, as suas alegrias, as suas admirações, as suas dores

\footnotetext{
${ }^{16}$ Expressão utilizada por Antonio Candido (CANDIDO, 1993:27) para explicitar o papel do poeta neste trabalho de construção do poema no interior de um sistema literário que prevê a literatura além do seu caráter de ditetantismo.
} 
e as suas sensações, toma consciência de si própria e se põe à mostra de certa forma regularizada num texto, inferindo, neste processo, o que mais significativamente contempla a idéia de "singularidade" e "pluralidade" da qual a obra literária se reveste.

Quando pensamos a singularidade de que cada texto literário é portador, fazemo-lo no interior de um sistema organicamente regularizado, que concebe a literatura como instituição capaz de acolher, sustentar e dar representatividade à produção de um agente em particular. Neste sentido,

as normas, as convenções, as virtualidades, as indeterminações e as tensões internas e externas destes sistemas possibilitam as práticas semióticas dos agentes, tanto as de natureza conservadora ou rotineira como as práticas de natureza inovadora e mesmo transgressiva que podem significar a desconstrução do sistema e o seu subseqüente reordenamento (AGUIAR e SILVA, 2000: 580).

É no interior deste sistema literário, marcado por uma pluralidade de vozes, que se registra a tensão entre o poeta, o teórico e o crítico, determinando a fronteira onde o gesto criativo e o gesto teórico ${ }^{17}$ figuram como elementos subordinados a uma espécie de sistematização interna das práticas semióticas individuais.

A voz de Aquino Corrêa emerge de um sistema literário considerado tradicional, sob o qual, até então, se assentava Mato Grosso, suscitando repensar as práticas semióticas que sustentam este sistema, propondo parâmetros para se pensar o seu subseqüente reordenamento.

Segundo posicionamento crítico do próprio escritor, "um bispo, a dedilhar assim as cordas de uma lira, em plena manhã do século XX, tem evidentemente, sequer entre nós, algo de novo, que merece ser estudado, e impõe mesmo a necessidade deste proêmio" (CORRÊA, 1985 a: 21).

\footnotetext{
${ }^{17}$ Terminologia utilizada pelo poeta, professor e ensaísta Ernesto Manuel de Melo e Castro, no ensaio Poesia/Transpoesia/Repoesia:alguns tópicos atuais nas poesias brasileira e portuguesa, publicado na Revista USP, São Paulo (36):116-127, DEZEMBRO/FEVEREIRO , 1997-98.
} 


\subsection{A escrita e o estudo analítico do poema: procedimentos fundamentais à crítica literária}

$\mathrm{Na}$ perspectiva em que conduzimos este estudo, atentos aos elementos referentes à forma e à matéria da poesia, é preciso notar que à crítica literária interessa o estudo analítico do poema centrado em dois aspectos fundamentais, o primeiro, aborda os estudos sobre os fundamentos do poema, e, o segundo, referencia a significação simbólica das suas unidades expressivas.

Nas pressuposições que referenciam os fundamentos do poema, atentamos, a princípio, para a questão da sonoridade, nos termos que nos assevera Antonio Candido, na segunda parte da sua obra O estudo analítico do poema (2006:37-101), que antes de qualquer aspecto significativo mais profundo, o poema tem uma realidade liminar, ele é "uma estrutura sonora".

Os estudiosos da arte literária devem considerar que esta sonoridade pode se revelar de maneira altamente regular, muito perceptível, determinando uma melodia característica na ordenação dos sons do poema através do metro, do ritmo e da rima, ou pode ser de tal maneira discreta que praticamente não se distingue da prosa, dando origem à prosa poética.

No verso metrificado ou no livre, essa sonoridade se revela na beleza plástica do poema como um todo ou individualizada no verso, na rima, no ritmo e no metro. Tal revelação se faz observável através do conjunto de fonemas que, numa série de combinações, formam as sílabas poéticas responsáveis pelo ritmo, cuja seqüência combinatória produz o metro, ou seja, as unidades maiores de base alternativa, que funcionam como recursos utilizados pela poeta para dar forma à matéria.

O metro é a unidade fundamental do poema, e tem compromisso com o verso, distinguindo-se assim, fundamentalmente, da frase. O metro interessa à poética para dar efeito estético e cadência melódica ao verso, ao passo que a frase interessa à lingüística, como forma que se apresenta através de frases e períodos como estruturas que atendem à relação de interlocução da língua.

Além destes elementos fundamentais de ordem formal, o trabalho criador também se efetiva em unidades expressivas constituídas através da linguagem poética, 
traduzida em palavras e combinações de palavras condutoras de significados e valores simbólicos, revelados pela língua literária.

Esta linguagem, na sua função poética, se representa no corpo textual do poema através de signos normais, de figuras, de imagens, de metáforas, de alegorias e de símbolos que se constituem como a base concreta para os estudos analíticos e críticos que respondem pelos juízos valorativos da qualidade estética do trabalho criador do poema.

Segundo Antonio Candido (2006: 103), esta fusão do gesto criativo com o gesto teórico, no interior do poema, efetua-se através de uma operação semântica peculiar que consiste em arranjar as palavras de maneira que o seu significado apresente ao leitor um supersignificado, próprio ao conjunto do poema, o que vai constituir o seu significado geral. É pelo conhecimento deste significado geral, que o juízo valorativo do poema adquire peso que interessa à crítica literária e à fortuna crítica de um escritor, em particular.

Neste processo, que a língua literária sustenta, identificam-se vestígios de formações culturais características, individualizadas no escritor e no contexto sóciocultural em que este se torna representante.

No caso de Aquino Corrêa, os elementos fundamentais de ordem formal e as unidades expressivas, que dão o corpo textual dos seus poemas, filiam-no ao Classicismo, ao Romantismo e ao Parnasianismo.

\subsubsection{A forma e a matéria do poema}

Aquino Corrêa nos textos de abertura de Odes, obra editada pela primeira vez em 1917, e de Terra Natal, editada três vezes, sendo uma em 1919, outra em 1922 e a última em 1940, formula juízos críticos que suscitam questionamentos sobre poesia, e nos quais nos apoiamos para constituir um marco inicial e parâmetros para pensarmos criticamente a forma e a matéria da poesia produzida em Mato Grosso.

A princípio, percebemos Aquino Corrêa no universo do poeta, como o tipo de homem que é dotado de um senso especial em relação às palavras, e que somente 
com ele ocorre o fenômeno chamado "inspiração", o que Antonio Candido (CANDIDO, 2006:104) traduz como uma espécie de força interior que leva o poeta a buscar certos caminhos da expressão.

Conflui, para o raciocínio de Candido, o pensamento de Aquino Corrêa, segundo o qual, "o ato criativo reside na inspiração que é o espírito que vivifica a letra dos versos", cuja elaboração estética, à luz da crítica literária, subordina-se à elaboração conjunta de "duas entidades", através das quais tanto a forma como a matéria ou fundo concorrem para a constituição do objeto estético (CORRÊA, 1985 b, v. II, tomo II:18).

Muito a propósito, nos localizamos nesta confluência, e adotamos o princípio, segundo o qual "todo poema é uma estrutura sonora" (CANDIDO, 2006: 37), integrada por "unidades expressivas" e que somente o seu estudo analítico permite aferir valores conceituais significativos à produção de um agente em particular, no interior de um determinado sistema literário.

Nesta linha de pensamento, não registramos estudos mais aprofundados que tenham explorado sistematicamente os poemas de Aquino Corrêa.

\subsubsection{Fronteiras da forma e da matéria: o equívoco dos juízos críticos sobre os valores poéticos}

A preocupação em situar Aquino Corrêa no contexto das idéias literárias discutidas no Brasil, à época a que nos referimos (1902-1922), corresponde a um processo de atualização que atende à história da literatura produzida em Mato Grosso, situada na "dinâmica do movimento dialético entre o passado e o presente, executada por gestos criativos de novos atores históricos que, ao retomar uma modelização, mantém os predicados de base, que é o que garante uma identidade formal" (ABDALA JÚNIOR, 2003).

$\mathrm{Na}$ dinâmica do movimento dialético entre o passado e o presente, fundamentamos os estudos sobre a crítica literária da poesia em Mato Grosso, assentados nos princípios críticos próprios do Romantismo, do Parnasianismo e do Decadentismo-Simbolismo. 
Em uma extremidade, assinalamos o momento romântico, cuja trajetória crítica se volta para os aspectos que referenciam a temática desenvolvida através de unidades expressivas, que modelam a matéria poética voltada para a natureza, para os valores pátrios, para a religiosidade, para as figuras idealizadas e para os "amores puros"; em outra extremidade, assinalamos o momento parnasiano, cujo apanhado crítico privilegiou a forma em detrimento da matéria, criando a ilusão da impassibilidade do poeta diante da matéria que compõe os seus poemas.

No entremeio destas extremidades, em que, de um lado, se privilegia a matéria e, de outro, se privilegia a forma, destacamos os aspectos críticos característicos do momento decadente-simbolista, o qual traduz uma sensibilidade estética que se contrapõe ao Realismo e ao Naturalismo, desenvolvendo uma temática marcada pelo subjetivismo, pela descoberta do inconsciente e pelo gosto das dimensões misteriosas da existência. Esta sensibilidade é revelada através da elaboração de uma linguagem poética que privilegia as formas estruturais do poema, marcadas pelo poder da sugestão e expressas através da cadência melódica, do ritmo, das aliterações, das sinestesias e da musicalidade dos versos.

É possível entender este aspecto do simbolismo-decadentismo, que mais de perto nos interessa, como um desdobramento do subjetivismo próprio do Romantismo, o qual é alimentado pela reação ao cientificismo, que acompanha o desenvolvimento da sociedade industrial, e que na prosa se fez dentro do Realismo e do Naturalismo, e na poesia realizou-se através do Parnasianismo, do qual os simbolistas herdaram a paixão pelo efeito estético.

No Brasil, esse simbolismo literário de matiz decadentista encontrou expressão nas poesias de Cruz e Souza (1961-1898) e de Alphonsus Guimarães (1870-1921).

Reconhecemos que para a crítica literária, tais atitudes poéticas provocaram, no interior do sistema literário, ora um isolamento das unidades expressivas do poema, privilegiando as unidades formais esvaziadas de conteúdo expressivo, ora promovendo a supervalorização de aspectos temáticos revelados através das unidades expressivas, de alegorias, de metáforas construídas pelo poema.

Tais atitudes críticas diante do poema colocam, no primeiro caso, o escritor artífice, fechado numa "torre de marfim", difundindo o culto da "arte pela arte", através 
do preciosismo das palavras, da obsessão pela clareza e pelo rigor gramatical e formal do poema; e, no segundo, acentuam-se os aspectos reveladores da subjetividade do escritor.

É necessário distinguir, em Aquino Corrêa "o tipo de homem que faz versos", o qual se manteve fiel à sua formação de matriz clássica, e o escritor que pensa criticamente a poesia produzida em Mato Grosso, assentada na beleza da forma e na beleza da matéria.

Manifestando-se contrariamente ao princípio fundamental do movimento parnasiano, assinalamos o juízo crítico de Aquino Corrêa, segundo o qual, "a 'arte pela arte' é fórmula quimérica. A arte não pára em si, é feita pelo coração e para o coração, assim como este foi feito para o Infinito" (CORRÊA, 1985 a: 33). Para o escritor, a arte não suporta mediocridade, e o poeta que não edifica, se destrói.

Este princípio crítico é reiterado, em um outro momento discursivo de Aquino Corrêa, para ilustrar uma evolução da crítica literária, que procurou preservar do Parnasianismo apenas parte do que este movimento estético significou quanto à beleza da forma poética assentada no esmero, na elaboração da língua literária:

A beleza da forma teve, como sabeis, a sua última palavra, nessa
escola parnasiana da segunda metade do século findo, que,
prestigiada por dois insulanos dos trópicos, Leconte e Herédia,
domina hoje, em boa hora, toda a literatura nacional.
Não falo, entretanto, do Parnasianismo na acepção estritamente
histórica que Ihe cabe, de corrente poética, mas num significado
mais amplo, que possa abranger também a prosa(...) Nem falo,
está claro, desse Parnasianismo decadente, já fulminado por
Euclides da Cunha, como a 'idiotice do culto fetichista da forma".
O Parnasianismo, tal qual aqui o entendemos, nada mais significa
senão a escola literária, cujo supremo ideal é a perfeição da
forma.Tudo o mais é aí secundário, ou mesmo extravagante.
Neste sentido é que ele foi incontestavelmente uma reação salutar
e fecunda contra as inspirações sinceras e fortes, mas, não raro,
descabeladas e revoltas do Romantismo (CORRÊA, 1985 b, v. II,
tomo II:18).

No que concerne ao privilégio dado às unidades expressivas do poema, Aquino Corrêa se manifesta criticamente, apontando que o poeta na ânsia da busca pelo novo, pelo extraordinário, pelo simbólico, afasta-se da razão e mergulha nas regiões nebulosas do sonho, correndo o risco de perder-se em abstrusas sutilezas metafísicas, 
sem nenhum esplendor de verdade, "refletindo o predomínio da paixão e da fantasia na alma do poeta, que sofre da inconstância e volubilidade dos seus ideais" (CORRÊA, 1985 a, v. I, tomo I: 24).

Constituímos a base do pensamento crítico de Aquino Corrêa no interior destas formulações, que caracterizam o princípio fundamental da arte decadente-simbolista, marcada por uma grande elaboração estética, acrescida da preocupação de colocar como ideal esteticista, a fusão entre a vida e a arte poética.

Nesta confluência da forma e matéria poéticas, a crítica literária se amplia e adquire maior complexidade sob dois aspectos referentes ao estudo crítico do poema: no plano formal, propõe o afastamento entre a poesia e a prosa, visualizando a arte poética livre de aspectos narrativos e descritivos para não perder a sua essência e pureza influenciada pela contaminação prosaica; e no outro plano, promove a aproximação da poesia com outras artes e outras formas artísticas, como a música e a pintura, privilegiando aspectos expressivos do poema.

As unidades expressivas próprias da função poética da linguagem, como a metáfora, a alegoria e a metonímia, cedem lugar a um processo simbólico mais apurado da linguagem poética, que privilegia elementos que traduzem os aspectos de sonoridade do poema, gerando "símbolos" que não comunicam o objeto estético de forma discursiva, mas sugerem idéias sem a lógica do pensamento racional da escrita, e sustentadas, em especial, pelas sinestesias e pelas aliterações.

\subsection{Hipótese: estudos críticos da poesia em Mato Grosso}

Observados os aspectos que orientam os estudos referentes à crítica literária, privilegiando a elaboração do texto poético, o que salta à vista, como um todo, é uma concepção de poema centrado em duas categorias estéticas, a beleza da forma e a beleza da matéria.

Estas duas categorias estéticas adquirem maior complexidade quanto mais se aproximam como elementos necessários à crítica literária, como formas reveladoras da essência poética ou do ideal da poesia. 
Respeitadas as particularidades poéticas que cada uma dessas categorias revelam, do ponto de vista de elaboração e do estudo analítico do poema, adotamos a concepção de que o poeta, o teórico e o crítico não se separam. Ademais, como nos faz notar Aquino Corrêa, "as coisas belas são difíceis de realizar e mais difíceis ainda de analisar cientificamente, máxime em serão, como este, tão cantante de música e letras, onde, por certo destoariam abstrusas sutilezas metafísicas" (CORRÊA, 1985 a, v. I, tomo I:17).

Para o escritor, à luz da crítica literária, distinguem-se, na obra literária, duas entidades, a forma e a matéria de fundo, e, nelas resplandecem também duas belezas: a beleza da forma e a beleza da matéria poética.

Colocamos em evidência estas considerações pelo fato de que a obra de arte possui uma natureza individual que está referida no interior do texto através de elementos singulares, pormenores textuais que evidenciam tanto a matéria quanto a forma, e a sua apreensão se vincula à necessidade de tratamento especializado, caso contrário, pode-se incorrer em "abstrusas sutilezas metafísicas", que nada acrescentam aos estudos literários.

De acordo com os encaminhamentos necessários ao desenvolvimento desta tese, afirmamos que a própria natureza da obra de arte está referida a uma singularidade, e que, para sua compreensão e esclarecimento, é necessário que se tenha o domínio de um conhecimento especializado, aliado a "uma imaginação aguçada, para que as imagens das configurações artísticas possam ser retidas em todos seus traços variados, e, em especial, para que possa tê-las presentes a fim de compará-las com outras obras de arte" (HEGEL, 2001, vol. I:38).

De fato, a constatação desta singularidade requer que o estudioso observe, na interpretação sistemática da obra de arte, elementos que nem tanto o prendam à forma e nem à matéria, os chamados formalismo e materialismo, nem se perca em interpretações que brotam pela sugestão.

Antonio Candido (2006: 29) afirma que uma interpretação coerente consiste em procurar extrair os aspectos formais e expressivos que estão contidos na obra.

Apoiados nesta afirmação, vemos que a crítica literária se interessa por uma interpretação coerente subordinada à análise, que é o levantamento de dados 
exteriores à emoção poética, uma espécie de decomposição do poema em unidades mínimas. A análise acontece através do levantamento analítico dos elementos formais, internos ao poema, sobretudo, àqueles que se ligam à estrutura fônica e semântica.

Convergindo para esta afirmação, Machado \& Pageaux (2001:120) acena para uma renovação no campo da crítica literária, ancorada na análise das influências, a partir de certos estudos analíticos que descobrem, no contexto das literaturas ditas "dependentes" ou "emergentes", riquezas inesperadas e novas possibilidades de interpretação das obras produzidas pelos escritores ditos "periféricos", os quais se desenham no sistema, preocupados em mostrar seu lugar face a uma tradição literária que simultaneamente os forma e os ameaça.

Colocamos Aquino Corrêa na posição de escritor "periférico", à proporção que o percebemos na fronteira entre o passado e o presente, lugar discursivo onde "o escritor poderá reorientar a tradição ou o modelo, completá-lo ou provocar uma ruptura, descrevendo com cada vez maior precisão a situação literária de um espaço geográfico, social e cultural" (MACHADO \& PAGEAUX, 2001:121).

Os estudos são apresentados numa perspectiva comparatista, por entendermos que este é um campo de estudos eminentemente interdisciplinares, que leva em conta três aspectos básicos da literatura que interessam à crítica literária: a morfologia ou o estudo das formas; a literatura como instituição e sistema regularizado; e a contribuição das ciências humanas para a reflexão sobre a poesia.

Para a apresentação deste trabalho, fazemos a abordagem da produção literária de Aquino Corrêa numa perspectiva geral, privilegiando o caráter essencialmente teórico, referente à morfologia ou ao estudo da forma dos seus poemas, e o discurso crítico com que este admitia a beleza literária assentada na beleza da forma e da matéria.

Mediante a relevância que procuramos dar às questões relacionadas à morfologia da obra nos estudos de crítica literária, e, para dar suporte teórico ao percurso que fazemos, para atribuir a Aquino Corrêa um marco significativo nas discussões sobre crítica literária em Mato Grosso, aliamos a afirmação de Guillén (1963:12) de que em um texto literário, a "face temática" é inseparável da "face formal", e o princípio crítico de Machado e Pageaux (2001: 113), segundo o qual, a crítica deve 
apreender, na obra o desabrochamento simultâneo de uma estrutura formal e de um pensamento, o amálgama de uma forma e de uma experiência que são solidários na gênese do crescimento de um sistema.

A terminologia "forma", no sentido proposto por Machado \& Pageaux (2001:113), aparece como designativa de uma unidade significante que dá acesso à organização interna do texto, permitindo a realização de estudos intertextuais de ordem histórica ou estilística da vida das formas literárias, implicando perceber processos tradicionais, relativamente codificados e fixos, como as convenções da versificação, os grupos estróficos e métricos que ordenam, orientam e condicionam a escrita poética.

Nesta dimensão, a produção literária de Aquino Corrêa observa dois planos: no primeiro, situa-se o conjunto de poemas do escritor representando o que Machado \& Pageaux (2001:114) denominam como "gênero real". Nesta ótica, o gênero é traduzido como uma forma historicamente definida, e conscientemente praticada pelo escritor Aquino Corrêa que, privilegiando as formas fixas representadas pelo soneto, ode, balada, epitalâmio, hino e écloga, filia-se às correntes literárias que se enraízam e se orientam na tradição clássica.

No outro plano, no conjunto dos discursos de Aquino Corrêa, verifica-se a dimensão teórica do que o escritor considera fundamental aos estudos literários: deixar de lado a filosofia do belo e apreciá-lo sob o prisma literário, considerando a arte poética assentada na beleza da forma e da matéria.

A leitura das obras de Aquino Corrêa esclarece a especificidade das formas adotadas pelo escritor, na sua produção escrita dividida em poesias, discursos e pastorais.

Uma vez que nos interessamos pela poesia e pelos discursos de Aquino Corrêa, as obras Odes (1985 a), Terra Natal (1985 b), Nova et Vetera (1985 c) e Discursos (1985, v. II, tomos I, II e III) enfeixam as produções que formam o chamado "modelo", nos termos tratados por Machado e Pageaux (2001:115), que tem a ver, essencialmente, com os estudos que referenciam a fortuna crítica do escritor.

Neste caso, o gênero praticado por Aquino Corrêa, é a conseqüência da sua formação, constituindo-se no aspecto específico da forma, implicando, portanto, todos os modos de execução e de expressão textual, em conformidade às convenções de 
versificação e de arranjo dos grupos estróficos e métricos, não devendo, portanto, ser concebido fora de um conjunto de elementos que alicerça o que se convencionou chamar de "sistema literário" (MACHADO \& PAGEAUX, 2001:11).

Segundo Machado e Pageaux (2001:118), os estudos realizados sob esta ótica implicam um notável avanço metodológico, no sentido em que reconciliam a exigência da historiografia literária com a necessidade de uma descrição rigorosa do processamento textual do fenômeno literário.

Esta linha teórica, que contempla principalmente os estudos realizados na área de Literatura Comparada, possibilita-nos criar, a partir de Aquino Corrêa, um 'modelo teórico' para pensar criticamente a poesia feita por escritores mato-grossenses.

A partir de Aquino Corrêa, pensamos um 'modelo teórico' para a crítica da poesia, levando em conta a língua literária, marcada pelo vocabulário clássico e formas particulares de organização estrutural, mais os temas voltados para a idealização, a descrição de valores morais, religiosos e pátrios. Este comportamento crítico se traduz como um reflexo ativo, uma resposta positiva, que procura orientar quer a imitação, quer a ruptura, quer a transformação, quer a transgressão do modelo, junto ao imaginário social.

Os aspectos fundamentalmente críticos dos posicionamentos de Aquino Corrêa suscitam uma reordenação dos princípios formais, que caracterizam a literatura produzida em Mato Grosso, em um período de transição em que, dada a sua localização geográfica, apresentava-se distanciada dos centros onde efervesciam as discussões em torno das idéias do Modernismo.

Desta forma, as opções como a escolha da língua e a escolha do modelo estético de produção textual, além de constituir um processo de criação opcional que carrega as marcas do sujeito historicamente constituído no interior do sistema, também implementam o processo de socialização de certas particularidades que representam marcas do escritor ou do sistema literário em que ele está inscrito.

No caso de Aquino Corrêa, essas marcas se traduzem na opção do escritor por preservar os alicerces da sua formação sociocultural no interior de um sistema, onde elementos como a língua literária, os temas e as figuras dos seus poemas formam um 
espécie de organismo que representa a literatura de um determinado período de Mato Grosso.

Quer consideremos os pontos de vista teóricos de Machado e Pageaux (2001113-118), que levam em conta a literatura como "sistema literário" sustentado por um conjunto de afinidades formais e materiais, quer consideremos a literatura como "sistema simbólico" ou "manifestações literárias", que, no dizer de Antonio Candido (1993:23-24), guarda em seu interior uma série de obras ligadas por denominadores comuns, que permitem reconhecer "notas dominantes de uma fase", o que interessa é estabelecer a voz de Aquino Corrêa como um divisor, suscitando posicionamentos num momento de transformação, em que o sistema literário característico de Mato Grosso se apresenta desencontrado dos discursos de ruptura promovidos por intelectuais das letras em outras regiões do Brasil, principalmente os do eixo Rio de Janeiro - São Paulo.

A voz de Aquino Corrêa caracteriza um momento literário nos moldes elucidados por Candido (1993: 24), com a literatura propiciando uma espécie de comunicação inter-humana, que leva em conta características internas do texto, como a língua, os temas e as imagens, mais os elementos de natureza social e psíquica que, literariamente organizados, representam um aspecto orgânico da sociedade, um sistema simbólico que sustenta "a formação da continuidade literária" como uma tradição, isto é,

transmissão de algo entre os homens, e o conjunto de elementos transmitidos, formando padrões que se impõem ao pensamento ou ao comportamento, e aos quais somos obrigados a nos referir, para aceitar ou rejeitar. Sem esta tradição não há literatura, como fenômeno de civilização (Candido, 1993: 24).

Aliando-se aos princípios teóricos elencados na perspectiva de Machado e Pageaux (2003) e na de Antonio Candido (1993), criam-se parâmetros para pensarmos os princípios da crítica literária do ponto de vista histórico, quando obras e escritores aparecem por força da "perspectiva escolhida" (Cândido, 1993: 24), integrando em dado momento um sistema articulado e, influindo sobre a elaboração de outras obras, 
tanto nos parâmetros da imitação como da transgressão, formando, no tempo, uma tradição.

Pensando em uma fase inicial para a história da crítica literária, na avaliação da literatura produzida em Mato Grosso, Aquino Corrêa representa um vanguardista quando tenta organizar um meio para formar grupos, elaborar uma linguagem e despertar interesse pelo estudo crítico das obras que podem registrar valores tanto de ordem das influências de outras literaturas como fazer parte de uma elite que, Antonio Candido (1993:24-25) denomina como "intelectuais ilustrados, homens de letras formando conjuntos orgânicos e manifestando em graus variáveis, a vontade de fazer literatura brasileira".

No dizer de Candido (1993: 24), temos "manifestações literárias" que não representam um sistema literário em particular, todavia significam um esboço, uma tentativa de estabelecer determinadas articulações que, no interior do macrossistema literário, ecoam como unidades culturais que resultam em projetos de formação da autonomia da cultura literária.

Ancorados nesta pressuposição, coloca-se em voga que o ponto de partida da crítica literária reside na velha concepção da literatura como expressão da realidade local e, ao mesmo tempo, elemento positivo na construção do sistema literário nacional.

Esta concepção, revista numa perspectiva atual, possibilita considerar o discurso crítico de Aquino Corrêa sobre aspectos gerais e específicos de teoria e crítica literárias, expressos em seus poemas, em particular, e nos textos do prefácio de Odes (1985 a, v. I, tomo I) e Terra Natal (1985 b, v.I, tomo II) como um esboço, uma preocupação em relação à evolução da crítica literária em Mato Grosso.

A princípio, esta articulação se concretiza nos textos de Aquino Corrêa, através da manifestação e elaboração de temas comuns ao Romantismo, como a religiosidade, o nacionalismo e o regionalismo, que representam a matéria dos poemas como expressão da realidade local e, ao mesmo tempo, elemento positivo na construção do sistema literário nacional. Seguidamente, há todo um aparato de elaboração do texto literário, que leva em conta a língua literária e uma série de recursos que esta dispõe para efetivar o ato criativo e dar forma à matéria, em um texto literário. 


\subsection{A dimensão histórica: complexidade dos conceitos e dos contextos de surgimento da crítica literária da poesia em Mato Grosso}

Tivemos ocasião de referir que a literatura produzida por Aquino Corrêa está filiada, originariamente, a certos aspectos estilísticos que nos remetem ao classicismo, identificado como uma doutrina que prevê a criação literária subordinada a modelos, dos quais derivam a disciplina e as regras necessárias para a execução de uma obra perfeita. Tentados pela conceituação, adotamos o classicismo como conceito periodológico, conforme os termos propostos por Aguiar e Silva (2000: 507), que assim o conceitua para atender a uma necessidade da periodologia literária.

Sob esta bandeira, percebemos a pertinência da periodização para a organização epistemológica da literatura mato-grossense, assentada na racionalidade do processo histórico da cultura. Muito a propósito, Aguiar e Silva (2000) diz que é necessário, tanto no plano do conhecimento histórico como no plano do conhecimento teorético, constituir uma periodização literária como forma de identificar, organizar, delimitar e caracterizar fenômenos de surgimento, de continuidade, de ruptura e de mudança na literatura, esta entendida "como sistema semiótico, como instituição, como processo de produção e recepção de textos e, obviamente, como corpus textual" (AGUIAR e SILVA, 2000: 403).

A literatura, entendida como instituição, e o classicismo, conceituado como "sistema de normas e de padrões literários historicamente situado e determinado" (AGUIAR e SILVA, 2000: 508), localizam sistematicamente os estudos críticos sobre a literatura produzida em Mato Grosso, como resultante de um longo processo de maturação de idéias estético-literárias advindas da poética clássica da verossimilhança, da imitação da natureza, do intelectualismo, das regras, da imitação dos modelos greco-latinos e da finalidade moral da literatura.

Esta constatação, sob a égide da crítica literária, confere, a Aquino Corrêa, uma incontornável posição de referencialidade no âmbito da literatura produzida em Mato Grosso, nas últimas décadas do século XIX e nas primeiras do século XX, e também reflete de forma evidente, o lugar do escritor que assentado nestes princípios, escreveu 
poemas, submeteu-os à análise crítica, e elaborou os parâmetros necessários para se pensar criticamente a poesia.

Eis aí identificado o lugar do poeta, autor dos livros Odes, Terra Natal e Nova et Vetera (1985), que registram os poemas que refletem a formação sócio-intelectual e o estilo literário do escritor, e de Discursos (1985, v. I, II e III), que refletem os posicionamentos críticos de Aquino Corrêa, que podem caracterizar fenômenos de surgimento da crítica literária em Mato Grosso.

Mas qual seria, de fato, o mote que nos leva a buscar Aquino Corrêa, no início do século $X X$, com uma atualidade indiscutível e recorrente? Com que interesse suas obras são lidas nesta atualidade?

De fato, a leitura de Aquino Corrêa concentra o propósito de acrescentar, aos estudos literários desenvolvidos em Mato Grosso, aspectos sobre teoria e crítica literárias. Além do lugar do poeta, identificado na fronteira do gesto criativo e do gesto teórico, também tratamos de identificar o lugar do teórico e do crítico, que, nessa época, tratava de elaborar parâmetros sobre os quais se assentaria criticamente a poesia produzida em Mato Grosso.

O crítico português Castro (1993:151-181) ao tecer considerações sobre a crítica literária portuguesa, ao longo do século $X X$, é contundente em dizer que a crítica foi exercida como uma prática sem práxis, devido a dois fatores: primeiro, pela falta de lugar para a crítica, e segundo, porque a crítica não provinha de nenhum processo lógico, esgotando-se, quase sempre, na exegese temática ou na função analítica do crítico.

Por um viés do juízo de Castro (1993), percebemos uma situação semelhante em Mato Grosso, e assinalamos que Aquino Corrêa implementa as discussões sobre os labirínticos caminhos da poesia, analisados à sombra de princípios críticos, que excedem tanto a exegese temática do poema como a análise das unidades sonoras e expressivas do mesmo.

Assim sendo, o texto do poema, além de refletir uma produção inventiva, levanos à compreensão teórica da originalidade com que certos fenômenos literários praticados se registram como elementos desencadeadores de "processos de 
entendimento de algo novo, ou mesmo algo renovado, da produção literária que vai surgindo e se registrando no interior de um sistema" (CASTRO, 1993:163) ${ }^{18}$.

Este procedimento excede os aspectos de uma crítica impressionista e, no interior de um ecletismo metodológico acentuado da crítica literária, lança luzes sobre uma crítica "científica", no sentido proposto por Jorge Sena ${ }^{19}$, segundo o qual, "a crítica científica é uma exigência metodológica de cálculo e de verificação das observações, de modo que as afirmações disso e nisso se apóiem, libertando-as assim da contingência inverificável das opiniões divergentes" (In: CASTRO, 1993:162).

É neste sentido que a crítica literária tem a importante função de produtora de teoria, e o poema, com todas as suas características temáticas, sonoras e expressivas, constitui a preocupação primordial do crítico, projetando em seguida, a análise textual no contexto social do sistema literário, em que a obra se origina e deverá funcionar.

Neste panorama literário em que a crítica se torna uma práxis instituída,

o leitor, em maior ou menor grau, é capaz de produzir leituras suas, não só dos textos sobre os quais exerce a crítica, mas também sobre os textos críticos que o crítico lhe propõe, estabelecendo relações entre ambos, em termos comparativos, por vezes de opções radicais ou apenas de entendimentos diversos" (CASTRO, 1993:164).

A crítica, neste caso, esclarece o elo entre o gesto criativo e o gesto teórico construído em uma fronteira temporal, onde o texto criticado/analisado representa um posicionamento anterior, centrado no autor, e o texto gerado a partir da leitura crítica reflete a recepção de um momento presente do texto, percebido pelo leitor. Este movimento dialógico estabelece as relações intertextuais que sugerem o tempo futuro sempre aberto às possibilidades de outras leituras.

Este movimento coloca a crítica como revitalizadora da teoria assentada em dois princípios: um, que postula o estabelecimento das relações intertextuais presentes no texto analisado e no próprio texto crítico produzido, inserindo-os como fontes, na

18 CASTRO, E.M.de Melo e.O fim visual do século XX e outros textos críticos.Nádia Battella Gotlib(org.).São Paulo:Editora da Universidade de São Paulo, 1993.

${ }^{19}$ Em "Da Crítica-Elementos para um Panorama Sincrônico, publicado em Literatura Portuguesa de Invenção, São Paulo:Difel, 1984.(In:CASTRO, 1993:151-172) 
pluralidade de um contexto cultural; outro, que é produto de um princípio de filtragem e opção do crítico, que vê no texto analisado uma peculiaridade, com a qual ele se identifica e desenvolve o seu texto crítico, possibilitando a construção de antologias e de uma fortuna crítica sempre sujeita a novas leituras.

Compreender o fenômeno literário, na perspectiva crítica de Aquino Corrêa, não significa apenas descrever os aspectos formais de uma obra ou apontar as suas afinidades estilísticas. Significa, acima de tudo, revelar como os procedimentos literários individuais podem interferir teoricamente no registro de um perfil literário, que reflete uma coletividade no interior de um sistema. É neste movimento que compreendemos a leitura como um procedimento crítico e uma "prática dialogal, que altera os referentes diacrônicos originais dos textos e os relança em circulação num novo conjunto sincrônico, fazendo com que adquiram referentes novos e atuais" (CASTRO, 1993:164).

A aproximação de Aquino Corrêa ao Classicismo repercute ecos da literatura greco-latina, que privilegiava o escritor que se distinguia pela beleza e correção sobretudo pela correção lingüística - com que elaborava as suas obras. Esta constatação marca nos estudos literários uma passagem, ou mudança de foco de aspectos relacionados ao escritor para aspectos específicos da obra.

Parafraseando a crítica de Castro (1993) sobre a crítica literária em Portugal ao longo do século XX, dizemos que os posicionamentos críticos de Aquino Corrêa (1985 a: v. I, tomo I: 17-45), que vieram a lume em 1917, postulam uma crítica literária voltada para o poema, dinamicamente positiva e antiestática, que contraria o pendor impressionista que parece dar um "brilho falso" à vida cultural de Mato Grosso, nas primeiras décadas do século XX.

Atentos à proposta teórica de Aquino Corrêa, de deixar de lado a filosofia do belo e analisá-lo unicamente sob o prisma literário, ancoramo-nos na crítica de Castro (1993:175), segundo a qual, a crítica nos seus fundamentos teóricos e na sua prática significa discutir a poesia no interior de um sistema literário em três poéticas concorrentes: a do autor, a da escritura e a da leitura, todas sempre presentes em qualquer ato de leitura, porém, em formas diferentes. 
Para fazer a abordagem dos fundamentos teóricos da crítica literária sob a ótica proposta por Castro (1993), torna-se necessário elucidar a nossa opção em preservar o uso do termo "poética", tal como é utilizada pelo crítico.

Neste caso, a acepção dada por Ducrot e Todorov (2001), na obra Dicionário Enciclopédico das Ciências da Linguagem, é a mais adequada aos fins a que nos propusemos a chegar. Segundo os teóricos, o termo "poética", a princípio, designa "toda teoria interna da literatura"; em segundo, aplica-se "à escolha feita pelo autor" na ordem da temática, da composição e do estilo, e, por fim, "refere-se aos códigos normativos constituídos por uma escola literária".

Simpáticos a esta acepção e à ambição científica da "poética", convergem para elas os nossos interesses de, a partir de Aquino Corrêa, pensar as categorias críticoteóricas que sustentam a poesia produzida em Mato Grosso, visto que, sob este ângulo,

a poética se propõe elaborar categorias que permitam apreender ao mesmo tempo a unidade e a variedade de todas as obras literárias.A obra individual será a ilustração dessas categorias, ela terá um status de exemplo, não de termo último (...) a poética deverá elaborar uma teoria da descrição, que porá em evidência tanto aquilo que todas as descrições têm em comum quanto aquilo que lhes permite permanecer diferentes; mas não se preocupará em dar conta da descrição em determinado texto particular. Por conseguinte, a Poética será suscetível de definir um encontro de categorias do qual não se conhece por ora nenhuma ocorrência. Neste sentido, o objeto da poética é mesmo constituído mais pelas obras virtuais do que pelas obras reais (DUCROT \& TODOROV, $2001: 83-84$ ).

Amparados no princípio de que o objeto de uma ciência não é o fato particular, mas as leis que permitem explicá-lo no interior de um determinado sistema, esclarecemos que o que nos interessa, em particular, não é o conjunto das obras de Aquino Corrêa, nem a tarefa de dar uma interpretação "correta" das suas obras, mas, a partir do pensamento crítico de Aquino Corrêa, elaborar instrumentos que permitam analisar criticamente o seu discurso literário, enquanto princípio de engendramento de uma infinidade de textos que figuram como textos da literatura mato-grossense, e definir o discurso literário em relação a outros tipos de discursos, atribuindo-lhe um objeto de conhecimento, produto de um trabalho teórico. 
Retomamos a crítica de Castro para entender de que forma a poética do autor, a da escritura e a da leitura está presente na formulação crítica de Aquino Corrêa.

Pelo ângulo do autor, a poesia centra-se na problemática que o leva a escrever o texto. Esta problemática é fechada e só acessível ao leitor, através de hipotéticas tentativas de penetração naquilo que muitos chamaram de "o mistério da criação" (CASTRO, 1993:175), e que Aquino Corrêa (1985 a: 25) denomina como "inspiração", "a alma da poesia", ou mesmo, "um suspiro d'alma consciente ou não, para o Infinito", que se pode realizar através de várias formas artísticas:

Pois bem.Quando este suspiro é tão profundo e impetuoso que não se pode conter, mas irrompe e se incorpora, quer na palavra igualmente rija que plástica de um bloco de mármore ou granito; quer na palavra cantante de um pentagrama; quer, enfim, na palavra ao mesmo tempo, cantante, colorida e plástica do verso, temos então, a Arte, temos a Escultura, a Arquitetura, a Pintura, a Música, a Poesia (CORRÊA, 1985 a, v. I, t. I: 25).

O processo de escrita do texto prevê modos como a poesia se materializa na forma de um poema, em versos metrificados ou livres, através de unidades sonoras, fônicas e unidades expressivas, responsáveis pela ligação entre o autor e o leitor, em uma aproximação que deve ser racional, metodológica, intuitiva e emocional.

Para Castro (1993: 176), a poética de escrita do poema "vai da emoção do autor à emoção do leitor", através de procedimentos específicos de escrita, de um conhecimento recíproco de categorias, do afastamento espacial e temporal e de conexões ignoradas e irreconhecíveis, além de totalmente imprevisíveis.

Finalmente, a leitura do poema efetiva a idéia da interpretação e, conseqüentemente, a possibilidade da crítica, visto que o leitor "penetra num mar de signos ou circunstâncias sígnicas", que provocam respostas em quem lê, suscitando "outros níveis sígnicos, conceituais, emocionais, ideológicos ou lúdicos" (Ibidem, 1993:176).

Essa relação de intimidade e cognição entre autor e leitor subsidia a possibilidade ou a impossibilidade da crítica literária, assentada numa fronteira interdisciplinar, onde entram em concorrência a Semiótica e a Hermenêutica (Ibidem, 1993:176). 
Da Semiótica leva-se a efeito a noção peirceana do signo "interpretante", como sendo o signo que se forma na mente do leitor, sob o estímulo dos signos primários ou o "representamen", utilizado pelo escritor no processo de elaboração do texto; da Hermenêutica leva-se a efeito o sentido possível das combinações presentes no texto, estabelecendo a relação íntima e subjetiva entre o sujeito que escreve e o que lê.

Esta confluência de subjetividades e cognição, todavia, não ocorre aleatoriamente, no interior do sistema literário, ela é regulada pelo que Aquino Corrêa (CORRÊA, 1985 a: 17) denomina por "bom senso na poesia" e figura como condição essencial de aproximação entre o escritor e o leitor:

Ao poeta nunca deverá esquecer que é homem, e vive entre homens a ele irmanados pelo mesmo ideal.Não se repute, nem se torne um ente extraordinário ou anômalo na sociedade.Ao tomar a lira, não abdique a realeza de um caráter bem formado, harmônico, inteiriço.Se a poesia não é razão pura, não é tampouco a fantasia tresloucada.Nem o abstruso que mal se entende, nem o absurdo que não subsiste poderão jamais ser poéticos.O belo é sempre claro, límpido e radioso (CORRÊA, 1985 a: 30).

À procura do rigor para se pensar criticamente a poesia produzida em Mato Grosso, conforme os parâmetros preconizados por Aquino Corrêa, que procuram levar em conta a beleza da forma e da matéria poética, ressaltamos os posicionamentos críticos de estudiosos da literatura mato-grossense, os quais julgamos que, efetivamente, tenham esboçado percursos críticos mais aproximados aos postulados por Aquino Corrêa.

Neste sentido, elencamos os autores e as obras, cujas manifestações críticas sobre a poesia mato-grossense refletem, com maior ou menor nitidez e objetividade, preocupações deste teor. Sendo eles: Lenine de Campos Póvoas, autor de A História da Cultura Mato-Grossense, editado em 1982, pelo Instituto Histórico e Geográfico do Mato Grosso e pela Academia Mato-Grossense de Letras; Rubens de Mendonça, de quem utilizamos a versão revisada e atualizada da sua História da Literatura MatoGrossense, cuja edição especial foi lançada em 2005, pela editora da Universidade do Estado de Mato Grosso-UNEMAT, acrescida no capítulo final por uma pequena fortuna crítica, a qual representa uma visão atual da crítica literária da poesia em Mato Grosso; 
Hilda Gomes Dutra Magalhães, com a obra História da Literatura de Mato Grosso: século XX, publicado em 2001; Carlos Gomes de Carvalho, com a obra A poesia em Mato Grosso, publicada em 2003; Padre Pedro Cometti, com a obra Dom Aquino Corrêa: Arcebispo de Cuiabá, Vida e Obra, publicada em 1994; Nancy Lopes Yung Delbem, com a dissertação de mestrado "Imortalidade e Discursos: a presença lusitana e a língua portuguesa no espaço cultural de Mato Grosso", defendida em 2002, junto ao Departamento de Letras Clássicas e Vernáculas, da Faculdade de Filosofia Letras e Ciências Humanas, da USP, na área de Estudos Comparados; e por último, os ensaios críticos de João Antônio Neto, Dom Aquino, o orador e, O Modernismo em Mato Grosso: reencontro com Silva Freire, lançados em 2001, em comemoração aos 80 anos da Academia Mato-grossense de Letras.

\subsection{Formação da consciência crítica: contextos de surgimento da crítica literária da poesia em Mato Grosso}

Ao iniciarmos este sub-capítulo na abordagem específica dos posicionamentos críticos de estudiosos da cultura mato-grossense, apoiamo-nos em Machado \& Pageaux (2001:134-145) para referenciar as figuras do investigador e do crítico que, no interior do sistema literário, desempenham o papel de ampliadores do sentido da literatura não só como um conjunto de textos, mas como atividade que inscreve o homem na cultura, na história e na evolução social de uma nação.

Em uma perspectiva comparatista, "a reflexão teórica não é a repetição e a generalização de teorias literárias diversas, mas sim, no princípio como no fim, uma reflexão sobre as dimensões novas duma questão literária". Ao investigador compete "a criação de um verdadeiro campo de investigação através de novas fronteiras em que o estudo desenvolvido pela incursão feita no interior de outras literaturas, chega a repor ou significar em outros termos um determinado problema literário" (MACHADO \& PAGEAUX, 2001:135). A reflexão deve corresponder, de fato, à criação de um novo campo de investigações, e, assim, a atividade crítica do discurso sobre literatura inscreve no seio do sistema literário um novo dado teórico. 
Aguinaldo José Gonçalves, autor do ensaio "A Propósito da Crítica de Marcel Proust" ${ }^{20}$, recorre a uma consideração feita pelo filólogo e ensaísta alemão, Ernest Robert Curtius, segundo a qual, "a verdadeira crítica tende a descobrir os elementos formais da alma de um autor, e não suas opiniões, nem seus sentimentos" (In: PROUST, 1994:9-39), para ilustrar um momento da crítica literária que parece desconhecido a muitos que se dedicam aos estudos literários:

Em 1924, o ensaísta alemão já fornece a chave do verdadeiro pensamento crítico que tantos e tantos, em 1992, ainda não encontraram."Tender" à descoberta dos elementos formais da alma de um autor consiste em mergulhar nos elementos internos da obra, pactuando-se o máximo possível com a "metáfora" do discurso artístico, para que seja possível, uma vez bem recebida, que ela seja bem percebida.Só assim torna-se plausível formar uma concepção da obra (In: PROUST, 1994:31).

O posicionamento crítico de Gonçalves aliado à conceituação do termo "estilo", como "a escolha que todo texto deve operar entre um certo número de disponibilidades contidas na língua" (Ducrot \& Todorov, 2001:274), corroboram com a nossa idéia de que a crítica literária desenvolvida em Mato Grosso, a princípio, filia-se a uma tradição assentada na observação de determinados códigos normativos, constituídos por uma escola literária no que se refere tanto à forma como à matéria poéticas.

Ancorados nesta premissa, trilhamos os percursos da crítica literária em Mato Grosso, através da apreciação dos posicionamentos críticos manifestados pelas vozes de Póvoas (PÓVOAS, 1982); Magalhães (MAGALHÃES, 2001); Carvalho (CARVALHO, 2003); Mendonça (MENDONÇA, 1970 (Ed. 1) e 2005(Ed. 2, esp) Cometti (COMETTI,1994); João Antônio Neto (NETO, 2001) e no texto de 2001, de Nancy Lopes Yung Delbem (DELBEM, 2002) .

A título de esclarecimento sobre a metodologia utilizada por nós, no desenvolvimento desta pesquisa, baseada em fontes secundárias, fazemos um recorte na fala do historiador Póvoas (1982), que salienta, no prefácio de sua obra História da Cultura Mato-Grossense, a dificuldade com que os pesquisadores se defrontam na pesquisa de dados, em virtude da precariedade de arquivos, resultante do desprezo

20 PROUST, Marcel. Nas trilhas da crítica. Trad. Plínio Augusto Coelho. São Paulo: Editora da Universidade de São Paulo: Editora Imaginário, 1994. (Críticas Poéticas; vol. 1). 
que outrora houve na preservação de tudo que dizia respeito à nossa memória histórica (PÓVOAS, 1982:17). Segundo o escritor, sua obra objetiva reunir elementos para transmitir informações que possam um dia ser úteis aos pesquisadores do futuro.

Em relação à poesia em Mato Grosso, nas últimas décadas do século XIX e nas primeiras do século $\mathrm{XX}$, a avaliação que Póvoas faz se circunscreve na esfera da historiografia e da crítica estilística. Póvoas elenca os poetas que nos últimos anos do século XIX e nos primeiros do século XX produziram poemas que guardavam características da poesia épica, parnasiana, simbolista e satírica.

Atentos à formação de uma consciência crítica da poesia assentada na elaboração da matéria e da forma, registramos o posicionamento crítico de Póvoas (1982: 80) como ponto de partida para a apresentação destes estudos. De acordo com o historiador, após o advento da República (1889) até a Segunda Guerra Mundial (1939/1945), Mato Grosso começa a colher os frutos de uma semeadura cultural feita anteriormente com a criação de colégios e fundação de órgãos de imprensa, registramse neste período mais de duas dezenas de bons poetas, sendo parnasianos a maioria, simbolistas outros e satíricos alguns.

$\mathrm{Na}$ tríade de poetas parnasianos, simbolistas e satíricos classificados por Póvoas, interessam-nos os satíricos. Para Póvoas (1982), o teor satírico que a poesia apresentou nessa época, transformou-a em instrumento de crítica à política praticada pelos governantes.

Sem interesse em discutir esta "instrumentalização" da poesia, reiteramos que o que consideramos pertinente à crítica literária, em particular, nesta avaliação feita por Povoas, é o processo de elaboração da matéria temática executado através da utilização da linguagem oral na língua literária.

Esta inovação interessa à crítica literária, à medida que privilegia o estilo individual e documenta a tentativa de cunhar um padrão literário assentado numa modalidade escrita, em que o escritor no processo de viabilização da sátira recorre à oralidade.

No interior de um sistema literário considerado tradicional, traços como este individualizam o escritor Frederico Prado de Oliveira apontando para uma espécie de ruptura, em um determinado momento da história da poesia produzida em Mato Grosso. 
Sob o pseudônimo de "Zé Capilé", o escritor escreveu versos que satirizavam o ambiente político, e criticavam o governo do Coronel Antônio Paes de Barros, o Totó Paes, que nomeava para postos administrativos os chamados "paus rodados", designação depreciativa dada pelos cuiabanos às pessoas que, vindas de outros estados da federação, ocupavam cargos políticos, supostamente, tomando o lugar do elemento local.

O poema satírico de Frederico Prado de Oliveira, que transcrevemos a seguir, representa uma forma que indica a penetração da oralidade na língua literária. Para veicular o seu discurso crítico, o autor adota uma forma que privilegia aspectos fonéticos vários, assistemáticos da fala popular que a grafia pessoal do escritor registra em forma de texto.

\author{
Uma coisa mi bule nispinha, \\ I mi dá um tremo na pacuéra: \\ É num vê meus patrício ninhum \\ Qui mereça justiça - divéra! \\ Só si vê a canáia di báxo, \\ Pau rodado qui aqui incaiô, \\ Priquitada im redó du guverno \\ A chupá tudo nosso suô (In: PÓVOAS, 1982: 81).
}

Visto que o nosso objetivo não é fazer estudo analítico de poema, nem traduzir palavras e expressões lingüísticas utilizadas pelo escritor para manifestar o seu discurso, procuramos manter-nos fiéis à proposta que interessa à crítica literária, de, a partir do postulado teórico de Aquino Corrêa, perceber o poema como uma categoria estética que traduz o processo de elaboração de uma forma e de uma matéria capaz de expressar uma singularidade do escritor, no interior de um sistema literário.

Para reforçar a singularidade de cada autor, referente à elaboração da forma, constituindo uma categoria estética capaz de viabilizar a sátira centrada na penetração da oralidade na língua literária, privilegiando além dos aspectos fonológicos, os aspectos lexicais e expressões próprias da fala popular, registramos o poema de Indalécio Leite Proença, que foi publicado em um folheto intitulado "Sátiras Anônimas", criticando o governo do Arcebispo cuiabano Dom Aquino Corrêa. 
Se a Bahia é boa terra,

Mato Grosso inda é mió;

Pau rodado cria proa

Furta bem, enche o bocó.

Dom Benito já tá feito;

É sapão de Três Lagoas

A questão é só de jeito

Pois o resto vai à toa...

Decorrido algum tempinho,

Ele vai pra relação;

Salvo se o seu bentinho

Não tivé mais devoção.

Assembléia inté já fez

Lei pra ele e Barnabé:

Um conto de réis por mês

Não é mimo pra quarqué. (In: PÒVOAS, 1982: 85)

Ao se referir ao movimento modernista em Mato Grosso, Póvoas (1982) celebra o empenho dos escritores mato-grossenses Gervásio Leite, Rubens de Mendonça e Eurides Mota, em "transmitir à inteligência mato-grossense esse dinamismo criador que sacode todo o país na hora decisiva em que vivemos" (PÓVOAS, 1982:101) e lançar o "Movimento Graça Aranha" através do qual procuravam despertar uma consciência crítica desse período de mudanças.

Esta alusão a Graça Aranha nos leva a Alfredo Bosi que em sua História concisa da Literatura Brasileira (1994, o coloca como o intelectual que se empenhou até o final da vida na teorização de uma estética mais aderente à vida moderna.

Diante do dinamismo das mudanças advindas com o movimento modernista, ousamos parafrasear Bosi, colocando Aquino Corrêa como o intelectual matogrossense, que, assustado com o dinamismo das mudanças, e interessado em dar solidez à estética literária, mais se empenhou com a teorização e com a crítica à poesia produzida em Mato Grosso, após o advento do Modernismo.

Neste sentido, interessa-nos o posicionamento crítico de Graça Aranha que, em seu ensaio Espírito Moderno: A emoção estética na arte moderna (1925), privilegia os aspectos relacionados à beleza da forma e da matéria da poesia, colocando que nenhum preconceito é mais perturbador à concepção de arte que o da Beleza. Para o conferencista, 
os que imaginam o belo abstrato são sugestionados por convenções forjadoras de entidades e conceitos estéticos sobre os quais não pode haver uma noção exata e definitiva.O universo e seus fragmentos são sempre designados por metáforas e analogias, que fazem imagens. Ora, esta função intrínseca do espírito humano mostra como a função estética, que é a de idear e imaginar, é essencial à nossa natureza. A emoção geradora da arte ou a que esta nos transmite é tanto mais funda, mais universal quanto mais artista for o homem, seu criador, seu intérprete ou espectador. Cada arte nos deve comover pelos seus meios diretos de expressão e por eles nos arrebatar ao Infinito. (...) É na essência da arte que está a Arte. É no sentimento vago do Infinito que está soberana a emoção artística derivada do som, da forma e da $\operatorname{cor}^{21}$ (ARANHA, 1925).

A atitude crítica metodológica implementada por Póvoas (1982) também é observada em Hilda Gomes Dutra Magalhães ${ }^{22}$ (2001), a qual vê, na práxis historiográfica da literatura brasileira, a utilização de uma variedade de métodos utilizada pelos historiadores, cada qual servindo a um objetivo específico e traduzindo uma teoria estética peculiar que varia conforme as descobertas da Teoria Literária. Segundo a escritora,

Essa variedade metodológica resulta em procedimentos críticos bastante distintos e variados, condicionando o "olhar" do historiador ora para os fatores intrínsecos da obra, ora para os extrínsecos, condicionadores do fazer literários (contexto histórico, social, etc), em busca da enfatização dos elementos que o teórico considera importante na literatura (MAGALHÃES, 2001:16).

Magalhães (2001:16) compila a história da literatura mato-grossense, buscando enfatizar as características estruturais e conteudísticas das obras salientando que

${ }^{21}$ Fonte:www.jayrus.art.Br/Apostilas/Literatura Brasileira/PreModernismo/Graça Aranha_... (12/09/07)

22 Hilda Gomes Dutra Magalhães é professora do Departamento de Letras do Instituto de Ciências e Letras do Médio Araguaia/UFMT.Doutora em Teoria Literária pela UFRJ e Pós-Doutora pela École dês Hautes Études em Sciences Sociales e pela Université de Paris III (Sorbonne Nouvelle), autora do ensaio Os princípios da Crítica Dinâmica, e da obra História da Literatura de Mato Grosso: Século XX (2001). 
ao analisar a literatura produzida em Mato Grosso não leva interesse em achar um fio condutor que caracterize a produção literária rumo a uma situação ideal, mas sim a sua variedade no tempo e no espaço, enquanto manifestações de formas diferenciadas de percepção do universo, estética e culturalmente (MAGALHÃES, 2001:16).

Magalhães acentua o caráter didático de sua obra, assentada na exposição, ou mapeamento, do panorama literário de Mato Grosso, feito cronologicamente, entendendo que essa metodologia permite mapear com maior precisão tanto o contexto histórico-cultural de cada década (...) quanto compilar a variedade da produção literária mato-grossense, evidenciando sua importância, enquanto diferença, no contexto literário nacional (MAGALHÃES, 2001:18).

Em relação à análise das obras literárias, Magalhães (2001:19) observa os princípios da Crítica Estilística, corrente crítica concebida como ciência-arte, caracterizada pelo exame do estilo do texto, entendendo por estilo "sua maneira, seus tiques, suas singularidades". Segundo a escritora, os textos foram explorados nos níveis estrutural e temático, buscando destacar as peculiaridades de cada autor e sua importância, no panorama literário de Mato Grosso.

Vista por esse ângulo, a historiadora utiliza-se do critério formal para dar lugar à produção poética de Mato Grosso em dois momentos distintos: no primeiro, referencia as produções poéticas das duas primeiras décadas do século $\mathrm{XX}$, assentadas no Parnasianismo, na referência da forma como peculiaridade que reflete a identidade estilística dos escritores; no segundo momento, conjugando forças com os conservadores, aparece uma estética progressista, representada por Lobivar de Matos, Manoel de Barros, Silva Freire e Wladimir Dias Pino, os quais "convivem com escritores ainda mergulhados na estética do século anterior, motivo pelo qual a melhor definição da literatura mato-grossense dessa época seja a de uma literatura plural e variada" (MAGALHÃES, 2001:96).

No primeiro momento, as obras dos escritores Aquino Corrêa, José de Mesquita, Frederico Augusto Prado, Aprígio do Anjos, Indalécio Proença e Arlinda Morbeck são apreciadas à luz do Romantismo e do Parnasianismo e consideradas "caudatárias da 
estética do século anterior" (MAGALHÃES, 2001:40); a outra corrente, considerada progressista, "é operacionalizada por um outro comando central, que é o da inovação estrutural". Esta inovação estrutural pressupõe aspectos que se relacionam à forma inovadora do poema acrescida por "uma abordagem crítica do mundo e, conseqüentemente, da visão dos elementos regionais, que tendem a ser universalizados" (Ibidem, 2001:313).

Assentados na bandeira de preservação da forma da poesia, preconizada através do movimento parnasiano, Aquino Corrêa filia-se à temática da poesia cristã e patriótica; José de Mesquita, influenciado por Musset, Bilac, Castro Alves e Alberto de Oliveira, filia-se à temática das poesias que mesclam razão e sensualismo; Frederico Augusto Prado, Aprígio do Anjos e Indalécio Proença filiam-se à poesia satírica; Arlinda Morbeck filia-se à poesia de caráter confessional e intimista.

Tomando por base as duas instâncias do belo que, na elaboração do objeto estético entram em concorrência, quer seja a beleza da forma, quer seja a beleza da matéria, reveladas através da forma peculiar com que cada escritor traduz o sentido das suas idéias, Magalhães (2001:43) analisa a poesia de Aquino Corrêa assentada no compromisso com a perfeição formal e os sentimentos nobres, ligados à terra e à religião, salientando que a matéria de seus poemas não é vista por um olhar distanciado, imparcial, mas por um olhar subjetivo, responsável pela faceta romântica dos seus textos.

A crítica literária ressalta o rigor formal empreendido pelo poeta na conformação e estruturação da matéria dos seus poemas, cujo tom é eminentemente subjetivo, religioso e patriótico, e observa a elaboração da linguagem poética aquineana como uma categoria formal, responsável pela expressividade da matéria alicerçada no poder das metáforas, das comparações, das frases exclamativas, das reticências e do purismo lingüístico.

Este percurso identifica um posicionamento crítico da escritora que converge para o postulado crítico de Aquino Corrêa, o qual evidencia a linguagem poética assentada no primor lingüístico, na beleza das imagens e na sofisticação das idéias veiculadas através do poema. 
Ao focalizar as décadas de 1930 e 1940, Magalhães (2001:96) confere à literatura produzida em Mato Grosso um status de passagem e de conciliação, conjugando forças conservadoras e progressistas, balizadas numa situação de tensão entre o antigo e o moderno.

A linha estética progressista é representada por escritores que convivem com outros escritores ainda mergulhados na estética do século anterior, motivo pelo qual a melhor definição da literatura mato-grossense, dessa época, seja a de "uma literatura plural e variada" (MAGALHÃES, 2001:96).

Magalhães (2001:36-92), nos primeiros decênios do século XX, elenca no mesmo capítulo as produções poéticas de Aquino Corrêa, de José de Mesquita, Frederico Augusto Prado de Oliveira, o "Zé Capilé", Aprígio dos Anjos, Indalécio Proença e Arlinda Morbeck.

Os poemas de autoria desses escritores estão filiados, em maior ou menor proporção, ao movimento parnasiano, por observarem determinadas categorias formais, e ao movimento romântico, por sedimentar a expressão da matéria ou do tema na subjetividade característica do escritor.

Assim, sob a bandeira de uma crítica literária consciente, esses escritores guardam determinadas peculiaridades formais e temáticas, e se instalam no interior da literatura produzida em Mato Grosso, como vertentes da poesia cristã e patriótica, praticada por Aquino Corrêa; poesia filosófica, reflexiva, didática e satírica, produzida por Indalécio Proença, Frederico Augusto Prado de Oliveira e Aprígio dos Anjos; poesia de autoria feminina, reveladora de uma temática diversificada, em que se inclui a família, a pátria e temas alusivos a datas comemorativas, é a que se registra nos poemas de Arlinda Morbeck.

Magalhães alude a outras formas peculiares à poesia de Arlinda Morbeck, que individualizam, de forma mais acentuada, a presença feminina na literatura matogrossense. Dado o caráter confessional de suas obras, estas, por vezes, assumem o estatuto de memória, e, em outras, o de diário, relatando os dramas da alma feminina às voltas com problemas conjugais. 
Pelo caráter essencialmente intimista da poesia de Arlinda Morbeck, esta se distancia da poesia de Corrêa e Mesquita, que mantém um caráter descritivo, por excelência. Segundo Magalhães (2001), nos poemas de Morbeck as imagens não são tão facilmente definíveis como as imagens da pátria exuberante de Aquino Corrêa ou as de Cuiabá de antanho, de José de Mesquita. Por este ângulo, conclui:

\begin{abstract}
A poesia de Arlinda Morbeck, soerguida nas emoções, retrata um eu-lírico submerso na solidão, nas incertezas e na angústia.E é através do mapeamento destas sensações e sentimentos que o amor é exposto, sob enfoques diversos. O primeiro deles é o amorilusão. Nesse caso, o amor é visto por um eu-lírico romântico, que concebe $\mathrm{o}$ mundo $\mathrm{e}$ as relações humanas pr uma lente transformadora (MAGALHÃES, 2001:82).
\end{abstract}

Nos casos citados, Magalhães (2001) procede à análise das obras assentada nos aspectos que se voltam para a temática desenvolvida pelos poetas. Salvo raras exceções, a crítica observa os aspectos formais dos poemas, privilegiando as unidades expressivas da linguagem poética.

Perseguindo os mesmos procedimentos críticos, observados em Póvoas e Magalhães, o escritor Carlos Gomes de Carvalho ${ }^{23}$ (CARVALHO, 2003), em sua obra $A$ Poesia em Mato Grosso: Um Percurso de Dois Séculos, apresenta a produção poética mato-grossense, do final do século XVIII ao início dos anos de 1990, analisadas à luz da crítica estilística e histórica.

Persistindo no postulado crítico de Aquino Corrêa (1985), que subordina a beleza literária à beleza da forma e do conteúdo poéticos, reconhecemos, conforme sugere Carvalho (2003:45), uma herança literária forjada nos parâmetros do Romantismo e do Parnasianismo, ora agarra-se ao conteúdo, ora agarra-se à forma.

Carvalho (2003) denominou o século XIX como "o século dos românticos ou de como a poesia percorre as vielas cuiabanas", privilegiando, portanto, a matéria poética que referencia a cultura local. Já as primeiras décadas do século XX, o crítico coloca o

\footnotetext{
${ }^{23}$ Carlos Gomes de Carvalho é advogado, professor universitário, poeta, contista e estudioso da literatura mato-grossense.Para o escritor, sua obra sintetiza uma proposta de recuperação e uma forma de indicar caminhos para que outros pesquisadores.
} 
momento em que "parnasianos e simbolistas compartilham ao lado de persistentes românticos (...) e a poesia satírica se transforma em arma de combate político", o que se infere nesta afirmação é que, a literatura está condicionada à produção de textos literários em função de uma estética que privilegia aspectos formais.

O elemento que diferencia o posicionamento crítico de Carvalho (2003), dos demais críticos citados anteriormente, é o fato de acentuar, no momento parnasiano, o privilégio da forma. Segundo Carvalho (2003), o Parnasianismo é caracterizado como o momento da "arte pela arte", explicitando que a arte poética, vista nessa perspectiva, não existe para a humanidade, nem para a sociedade e nem para a moral. Assim, a poesia parnasiana, que se apresenta objetiva na descrição da natureza, com evocações da história e de teorias filosóficas, proíbe as liberdades técnicas, acentua a importância do ritmo, caracterizando-se pelo realismo, universalismo e esteticismo dos temas, exclui o subjetivismo da poesia, negando a individualidade ao poeta.

Este posicionamento crítico de Carvalho (2003) converge para o posicionamento crítico de Aquino Corrêa, posto em evidência já nas primeiras décadas do século XX, segundo o qual,

a "arte pela arte" é fórmula quimérica. A arte não pára em si, é feita pelo coração e para o coração, assim como este foi feito para o Infinito.Poesia que não procure elevar os corações ao Infinito, não merece tal nome.Nisto, principalmente, é que "a arte não suporta mediocridade".O poeta que não edifica, destrói (CORRÊA, 1985 a: 33).

Corrêa (1985 a) ainda reforça o papel que o poeta deve desempenhar, enquanto edificador de cultura, no entrecruzamento do gesto criativo com o gesto teórico, citando o verso do poeta e crítico italiano Ugo Fóscolo ${ }^{24}$, que diz: "Odeio o verso que soa e que não cria!" (In: CORRÊA, 1985 a:33).

\footnotetext{
${ }^{24}$ Ugo Fóscolo - poeta e crítico literário italiano(1778-1827), escreveu poesias, peças teatrais, crítica literária e romances.
} 
Estas referências recortadas do discurso de Aquino Corrêa suscitam a averiguação de determinadas posturas críticas que soam um tanto equivocadas, visto que determinam o lugar de Aquino Corrêa como o "poeta de formação clássica que tinha no modelo parnasiano o seu ideal artístico" (MAGALHÃES, 2001:41).

De fato, a constatação no seio da literatura produzida em Mato Grosso de valores subsistentes do Parnasianismo, do Romantismo e do Simbolismo tem orientado o interesse de estudiosos sobre a necessidade de se conduzir os juízos críticos sobre uma avaliação consistente da poesia assentada no que Aquino Corrêa chama de duas belezas, "a beleza da forma e a beleza do conteúdo" (CORRÊA, 1985 a: 18).

Aquino Corrêa considera a poesia inata e que seu embrião é "sempre espontâneo", embora que muitas vezes é no fundo do peito que morre à mingua por falta de seiva ou sol", "quem há que se não tenha sentido poeta, sequer alguma vez na vida, muito embora não tenha sabido revelar ao mundo isso?" (CORRÊA, 1985 a: 30). Tal consideração aliada a este questionamento informam a dimensão da atitude teórica do poeta, diante do fazer poético. Não há como fazer poesia tendo-se apenas o motivo. Este, todos têm, mas apenas o poeta é capaz de expressá-lo.

Para Corrêa, a poesia é inata e tem um caráter universal. O homem e o poeta não se separam, para tanto há que se ter o bom senso de observar que:

ao poeta nunca deverá esquecer que é homem, e vive entre homens a ele irmanados pelo mesmo ideal.Não se repute, nem se torne um ente extraordinário ou anômalo na sociedade.Ao tomar a lira, não abdique a realeza de um caráter bem formado, harmônico, inteiriço. Se a poesia não é razão pura, não é tampouco a fantasia tresloucada (...) nem o abstruso, que mal se entende, nem o absurdo que não subsiste, poderão jamais ser poéticos. O belo é sempre claro, límpido e radioso (CORRÊA, 1985 a: 30).

Carvalho (2003:48) retoma o posicionamento de Póvoas (1985), ao considerar que, nas últimas décadas do século XIX e nas primeiras do século $X X$, acentua-se 0 subjetivismo poético herdado do Romantismo, porém revelado através "da ironia, da chalaça", dando origem a uma poesia penetrada pela ironia, recurso de linguagem que 
caracteriza a sátira impiedosa contra os governantes da época. Segundo o crítico, é bem verdade que essa poesia aparece sempre em simbiose com a atividade política, 0 que se traduz no juízo equivocado da poesia sendo usada como instrumento de crítica.

Também neste ponto, observa-se a reiteração do posicionamento crítico de Aquino Corrêa em relação ao uso da arte poética circunscrita na esfera de "instrumento". Para o crítico, equivocadamente, em muitos casos "faz-se da arte poética uma como carta de alforria para os mais comezinhos e imperiosos deveres do homem" (CORRÊA, 1985 a: 23).

Se atentarmos para o percurso metodológico adotado para o desenvolvimento desta tese, observamos que atribuímos a Aquino Corrêa uma marca de originalidade nos termos em que Sandra Nitrini $(2000: 141)^{25}$ a concebe, a partir de Odette de Mouergues, que elege a concepção do século XVI como a mais adequada, explicitando que

a originalidade que percebemos numa obra literária, ou seja, sua marca própria, não é outra coisa senão o gênio criador que levou um escritor a escolher um assunto, modificar uma técnica, etc., nas suas relações complicadas e variáveis com a tradição, com as influências específicas que agiram sobre ele e com o gosto de sua época (In: NITRINI, 2000: 141).

Nesta percepção, procuramos identificar no interior dos estudos críticos da literatura produzida em Mato Grosso, no período em evidência, o eco da voz de Aquino Corrêa como algo "original”, conforme a proposta de Nitrini (2000):

O original (novidade), dotado de espírito crítico, sabe decifrar e aperfeiçoar o que os outros descobriram. A palavra "perfeição", que se encontra no cume dos valores críticos, contém, de um lado, a idéia de transcendência do já conhecido, de outro, resvala a noção de monotonia e esterilidade.Um significado ou outro vai depender do lado por onde se sobe a montanha.A originalidade existe ou não, de acordo com o lado escolhido (NITRINI, 2000:141).

${ }^{25}$ NITRINI, Sandra.Literatura Comparada:história, teoria e crítica.São Paulo: Editora da Universidade de São Paulo, 2000. 
Visto que o nosso objetivo é acrescentar a contribuição de Aquino Corrêa aos estudos de teoria e de crítica literárias, em Mato Grosso, interessa-nos perceber o poema como o lugar de revelação de uma subjetividade peculiar, de uma transformação, portanto, sempre aberto a uma nova leitura, o que para a crítica literária se constitui em um novo momento que "decifra e aperfeiçoa o que os outros já descobriram" (NITRINI, 2000: 141). 


\section{CAPÍTULO 3}

\section{Trilhas a partir de Aquino Corrêa}

Para onde quer que nos voltemos, por toda a vastíssima área do nosso torrão natal, surge-nos, de toda parte, um mundo de memórias históricas ou lendárias, esvaindose no olvido, à mingua de quem as perpetue no ouro do lavor literário (CORRÊA, 1985 , v. II, t. I: 239). 
Propositalmente vamos registrando, em capítulos distintos, os posicionamentos críticos de estudiosos da literatura mato-grossense, os quais julgamos que, efetivamente, tenham esboçado percursos analíticos mais aproximados ao postulado crítico de Aquino Corrêa, o de fazer a contemplação da obra literária sob o prisma literário, que é o que nos interessa quanto à percepção da literatura de representação regional.

No capítulo anterior, ressaltamos os posicionamentos de Lenine de Campos Póvoas (1982) e de Hilda Gomes Dutra Magalhães (2001), por entendermos que refletem aspectos críticos sobre a literatura mato-grossense, conforme salientam pontos relacionados à matéria e à forma, importando na distinção da poesia satírica, da épica, da parnasiana, da simbolista e da modernista.

Reiteramos um posicionamento crítico de Póvoas (1982), neste capítulo, por nos parecer necessária a delimitação de uma fronteira, ou de um momento de passagem, em que se visualizam para a crítica da poesia, conforme as palavras de José Paulo Paes, "parâmetros da essência às formas de sua atualização histórica"26.

No que interessa aos estudos da poesia produzida em Mato Grosso, a crítica de Póvoas vale pelo que representa enquanto um parâmetro surgido, naquele momento de transição. Para o crítico, com o movimento modernista "nascia também, o verso solto, liberto da tortura da forma e da eloqüência parnasianas" (PÓVOAS, 1982: 99), e que, o poeta corumbaense Carlos Vandoni de Barros, ao que tudo indica, foi quem primeiro fez versos modernistas em Mato Grosso.

Ora, os poetas transformam matérias reveladoras de vozes em poesia, através de uma forma inusitada ou tradicional. O fato é que há uma "poesia nova". Para reconhecimento desta "poesia nova", Póvoas registra o poema O Cururu" ${ }^{27}$, de Vandoni, cuja matéria poética é cuidadosamente elaborada, preservando uma estrofação regular - são sete estrofes de quatro versos com rimas alternadas - que revelam a

\footnotetext{
${ }^{26}$ Fonte: BOSI, Alfredo. O ser e o tempo da poesia. São Paulo: Companhia das Letras, 2000. A citação é de autoria de José Paulo Paes, e encontra-se na "orelha" da obra de Alfredo Bosi.

${ }^{27}$ Cururu: tipo de dança de roda de origem indígena, que explora o movimento de todas as partes do corpo, além da voz. No cururu canta-se o desafio com todos os participantes da roda girando, sapateando e batendo palmas.
} 
sensualidade dos dançadores de cururu, tipo de dança de roda, palmeada e sapateada em que se canta o desafio. No trabalho de elaboração da matéria poética, o poeta explora aspectos da fala e do léxico regional, para dar forma ao seu poema.

O cururu

Fervilha o cururu no rancho de acuri, À luz de vela de garganta e de pavio, Enquanto se desfazem em prantos por ali Viola de ximbuva e tripas de bugio.

É assim que violeiro geme no bordão, Fazendo soluçar a música brejeira, As morenas bonitas que dançando estão, Acompanham cantando o coro a noite inteira:

Maré encheu, maré vazou.

O cabelo da morena,

Foi Batista que cortou.

Eu não tenho medo de onça, Nem de pinta que ela tem;

Tenho medo da morena, Quando chega a querer bem...

E o cantado destemido Já meio aqui, meio ali, Solta o verso que é aplaudido, Sorrindo cheio de si.

Lá na mata do Fuzi João Caetano me falo Que as muié do Taquari, Co'a vida dele acabô.

E na manhã seguinte quando o galo canta, E a madrugada, pouco a pouco, já se vê, A voz da morenada alegra se levantá, Tristonha a soluçar: "não deixa amanhecê!" (PÓVOAS, 1982: 99-100)

Maria Helena Nery Garcez, através do ensaio Fernando Pessoa e Antero de Quental: uma subversão do soneto $^{28}$, nos dá a tranqüilidade necessária para a defesa

${ }^{28}$ Fonte: Revista PersonaI, ${ }^{\circ}$ 5, Porto, Centro de Estudos Pessoanos, 1981.IN: GARCEZ, Maria Helena Nery. Trilhas em Fernando Pessoa e Mário de Sá-Carneiro. São Paulo: Moraes: Editora da Universidade de São Paulo, 1989. 
do nosso discurso que atribui a Aquino Corrêa o papel de precursor de um princípio crítico, que marca senão uma inovação nos estudos críticos da poesia produzida em Mato Grosso, mas talvez, o marco fundamental que traduz o deslocamento da figura do poeta para o modo particular e original com que este elabora a forma e a matéria dos seus poemas, determinando o seu valor artístico no interior do sistema literário.

Através de Garcez (1989:19-27), aproximamo-nos do posicionamento crítico de Pareyson ${ }^{29}$, que esclarece esse tipo de deslocamento, quando, pontuando a natureza dos gêneros e das formas em arte, adverte e orienta-nos que:

Seria injusto isolar e absolutizar alguns aspectos negativos que os gêneros e as formas em arte, aparentemente possuem, tais como o caráter supra-individual, abstrato e extrínseco, lembrando que é precisamente a normatividade inerente a eles que pode ocasionar a inspiração, oferecendo vigorosos estímulos, modos de fazer, para a produção artística ${ }^{30}$.

Segundo Garcez, este posicionamento crítico de Pareyson, em relação à natureza dos gêneros e das formas em arte, alerta aos estudiosos e críticos de arte literária que:

Num artista medíocre, gêneros e formas aparecem sem brilho algum, meros instrumentos indiferentes, despersonalizados, enquanto em obras bem-sucedidas eles ostentam o cunho da individualidade que os assimilou e recriou de maneira singular (GARCEZ, 1989: 19).

\subsection{Os conceitos não acabaram: poesia, história e religião}

A metodologia adotada para o desenvolvimento desta tese possibilitou-nos evidenciar, com clareza, a fronteira entre Aquino Corrêa - o poeta, autor dos poemas registrados em Odes, Terra Natal e Nova et Vetera (1985), cujas formas são reflexos da formação particular do escritor; e Aquino Corrêa - o crítico, autor de posicionamentos

\footnotetext{
${ }^{29}$ PAREYSON, Luigi. I Problemi dell' Estetica, ed.2. Milano: Marzoti Editora, 1966. Fonte: (Idem, ibidem: 19)

${ }^{30}$ Fonte: Op.cit. IN: GARCEZ, Maria Helena Nery. Trilhas em Fernando Pessoa e Mário de Sá-Carneiro. São Paulo: Moraes: Editora da Universidade de São Paulo, 1989.
} 
críticos registrados em Discursos (1985), os quais nos possibilitam pensar criticamente a poesia produzida em Mato Grosso.

Nos capítulos subseqüentes, teoricamente nos ancoramos em Compagnon (2001: 167), procurando privilegiar aspectos críticos, que mais significativamente, julgamos contemplar uma exigência da crítica literária moderna: perceber ao mesmo tempo a singularidade da obra literária, no interior de um sistema, e a liberdade de expressão do poeta, em escolher e arranjar os procedimentos elaborativos da sua criação artística.

Assim, formas de escritura da obra, noções de filiação a uma classe, uma escola, um gênero, um período, aliados a um arsenal de procedimentos expressivos de recursos disponibilizados pela língua, identificam um estilo individual do artista que se reflete na obra, denotando o lugar de assentamento desta no interior do sistema literário.

Nesta perspectiva teórica, as vozes dos pesquisadores Carlos Gomes de Carvalho (2003); Pedro Cometti (1994), Nancy Lopes Yung Delbem (2002) e João Antônio Neto (2001) refletem, mais objetivamente, comportamentos críticos diante do poema, mais diretamente aproximados dos postulados de Aquino Corrêa, assentados na teoria, na crítica e na história literária.

Teorizados por Wellek \& Warren (2003) ${ }^{31}$ como atividades distintas, a literatura e os estudos literários possuem relações de pertinência entre si, balizadas pelo tratamento da literatura enquanto uma arte criadora, e os estudos literários, senão uma ciência, uma espécie de conhecimento ou saber que traduz a experiência criativa da literatura em termos intelectuais, assimilando-a a um "esquema coerente que tem que ser racional para ser conhecimento" (WELLEK \& WARREN, 2003:3).

Sob esta orientação, os estudos literários possibilitam perceber que cada obra literária é tanto geral quanto particular. É geral, porque compartilha propriedades comuns com outras obras no interior de um sistema literário universal; é particular, porque mediante os estudos analíticos, inferem, nas obras de arte, certos aspectos individualizantes que tanto a crítica como a história literária reconhecem como a

\footnotetext{
${ }^{31}$ WELLEK, René; WARREN; Austin. Teoria da literatura e metodologia dos estudos literários. Trad. Luís Carlos Borges. Ver. trad.Silvana Vieira. São Paulo: Martins Fontes, 2003. (Coleção leitura e crítica).
} 
"individualidade de uma obra, de um autor, de um período ou de uma literatura nacional" (WELLEK \& WARREN, 2003: 9), constituindo a obra como uma singularidade, no interior de um sistema, cuja tendência é pluralizante.

Nesta perspectiva teórica, não há como negar a filiação da poesia praticada em Mato Grosso à matriz européia, e essa filiação só pode ser observada nos termos dos estudos críticos e comparados que privilegiam aspectos inerentes à forma e à matéria poética.

Mediante a leitura que fazemos da produção poética de Aquino Corrêa e dos posicionamentos críticos dos estudiosos da literatura mato-grossense, em relação à obra do escritor, possibilita-nos afirmar que o poeta se preserva em seus poemas, fiel à sua formação intelectual e à sua filiação genérica, em particular.

Porém, o teórico e o crítico literário se manifesta, com mais evidência, nos discursos que registram os princípios com que este pensava a poesia mato-grossense. Estes princípios críticos excedem o espaço dos seus textos e nos servem como parâmetros orientadores para os estudos que realizamos.

A poesia não é uma excentricidade, uma extravagância...É, em vez, tão natural ao homem, como uma, que é, das mais gloriosas perfeições que podem coroar-lhe a racionalidade.Não é flor exótica, mas muito nativa na celeste gleba da sua alma.O verdadeiro poeta não é um desorientado; é, pelo contrário, dos mais bem orientados entre os homens. Não tem destino diverso: orienta-se pelo mesmo ideal-o infinito (CORRÊA, 1985 a: 29).

Quais seriam os caminhos de orientação para a crítica literária da poesia matogrossense, a partir do escritor Aquino Corrêa?

Visto que realizamos nosso trabalho na base de uma metodologia comparatista, adotamos os conceitos de influência e recepção crítica propostos por Machado \& Pageaux (2001: 67), perseguindo o postulado teórico, segundo o qual, a recepção literária ou recepção crítica é de vital importância para os trabalhos de investigação dos comparativistas, dado que este procedimento é dialético, e somente, desta forma, é possível reconhecer, no interior de um determinado sistema literário, as formas que influenciaram na sua formação, e que, a princípio, orientam os estudiosos da literatura que buscam explicitar as suas bases e o seu reordenamento. 
Nestes termos, interessa-nos a forma particular como Aquino Corrêa percebe este sistema literário, sempre aberto às influências de outras obras ou escritores. Estas influências, no interior do sistema, não tonalizam uma literatura dependente das hegemônicas, mas acentuam um caráter particular de cultura, formado conforme a proposição teórica de Nitrini (2000: 195) ${ }^{32}$, mediante a integração progressista de experiências literárias e espirituais, individuais.

Esta integração acontece através da tensão entre os dados locais que, pela nossa ótica, se apresentam como matéria, como substância da expressão do artista e dos modelos herdados da tradição européia que se apresentam através da forma de expressão particular do escritor.

Retomando o conceito de influência proposto por Machado \& Pageaux (2001: 67), segundo o qual esta é percebida pela inserção de determinados aspectos característicos de uma obra, de um autor ou de uma literatura estrangeira num texto, vemos o discurso crítico de Aquino Corrêa sobre a forma e a matéria poéticas, perpassado por influências presentes não apenas nas suas produções poéticas, mas também no conjunto de textos críticos que manifestam os posicionamentos do escritor, que, preocupado em pensar a literatura produzida em Mato Grosso, tratava de elaborar os parâmetros críticos sobre os quais este sistema particular se assentaria e se distinguiria no interior de um polissistema.

Aquino Corrêa, à época em que aqui é enfocado, representa o escritor crítico que discute o papel do poeta na renovação da linguagem poética. O que nos chama a atenção em seus discursos é a imensa convicção com que apresenta as idéias, que podem orientar os estudiosos tanto na percepção do que verdadeiramente seja uma obra de arte, criativa, quanto no âmbito dos estudos analíticos que avaliam e traduzem a experiência criativa da literatura em termos intelectuais.

Aquino Corrêa não prescindindo de um caráter literário, que preserva as raízes de sua formação, concebe a literatura mato-grossense, vazada por influências estrangeiras, inscritas mais ou menos explicitamente no texto literário, leva-nos a estabelecer que as relações intertextuais fundamentam os estudos sobre literatura e

32 Paráfrase feita a partir da apreciação de Nitrini(2000:195) quando avalia o perfil comparatista de Antonio Candido na célebre formulação segundo a qual a dialética entre o"localismo e o cosmopolitismo constitui uma lei da evolução da vida espiritual do Brasil”. 
funcionam como estratégia de revitalização desses estudos mediante a percepção de como tais referências textuais contribuem para explicar tanto a produção de uma obra em particular, quanto o seu funcionamento no interior do sistema literário.

Esta concepção dialética do fenômeno literário que leva em conta as normas e as categorias estéticas, em particular, aquelas que marcam o gênero lírico, encontramola em Aquino Corrêa (1985), a quem distinguimos de outros escritores de sua época, em função do seu perfil crítico e das suas preocupações com a vida literária coletiva de Mato Grosso.

Além de se socorrer na religião, para enfatizar o caráter místico e transcendental da sua visão sobre poesia, Aquino Corrêa condiciona a elaboração do objeto estético às relações de influências das fontes responsáveis pela formação racional do poeta.

Os posicionamentos críticos de Aquino Corrêa, em relação à preservação da forma e da matéria poética, alicerçam nossos estudos sobre a poesia produzida em Mato Grosso constituída a partir de um processo formativo e dialético que se realiza através de leituras constantes.

Nestas leituras constantes, o conhecimento do leitor e do escritor alia-se à capacidade de reconhecer qualidades novas, a partir das categorias de juízo estético já existentes, e criam um "novo" texto literário que funciona como uma "resposta", mais ou menos nítida, a uma "expectativa" que existe no sistema.

Neste percurso, estreitam-se as relações entre o escritor e o leitor, formando fronteiras internas e intersubjetivas, onde o autor e o leitor crítico, graças a um aparato teórico, oriundo da sua formação, se confundem, diminuindo uma espécie de distância "estética" entre um texto literário considerado inovador e a expectativa crítica do leitor.

A título de esclarecimento das terminologias adotadas em um e outro momento da escrita do nosso estudo, explicamos que quando tratamos de poesia, tratamos do poeta e do autor, das relações abstratas de significado; quando tratamos de texto literário, de poema, tratamos das relações significantes, de concretude entre escritor e leitor.

Considerando que o texto literário está sempre aberto a novas possibilidades de leituras, e que este é, por excelência, o espaço de realizações tanto do escritor como do leitor, Aquino Corrêa, motivado por uma base de cunho vernáculo, traz, de tempos e 
espaços distintos, as influências que julgamos sustentar tanto o perfil do poeta como o do crítico e do teórico da literatura que defende a poesia manifestada através de uma forma que reflete o "esmero da linguagem, sem o que não há, nem pode haver beleza literária, e que apenas o estudo do vernáculo, na lição assídua dos modelos", é capaz de levar o poeta a realizar esta manifestação, "colecionando pacientemente, a bico de pena, as suas flores, cônscio de que escrever é como ler duas vezes" (CORRÊA, 1985 b: 19).

Enveredando por estes caminhos da crítica assentada no estudo analítico das unidades formais e expressivas do poema, que procuram considerar o processo de leitura e releitura de textos literários, consideramos que o escritor Aquino Corrêa tenha lançado as bases para uma modalidade de estudos críticos da literatura produzida em Mato Grosso, levando em conta as relações de intertextualidade entre os textos de uma mesma literatura e de literaturas diferentes ${ }^{33}$.

Isto se traduz em dizer que, por um lado, há dados referentes à matéria da poesia que possibilitam comentar aspectos individualizantes, presentes em textos de escritores de uma mesma literatura, o que Ihes confere o caráter de regional. Por outro lado, a análise dos elementos formais do poema insere a literatura produzida neste contexto, num sistema literário mais amplo que acolhe e legitima literaturas diferentes e Ihes confere o estatuto de literário, ou de literaturas que realmente valem a pena.

O fato de nos interessarmos pelo entendimento crítico do texto literário, através do estudo analítico da forma e da matéria, leva-nos a adotar as orientações teóricas sobre texto e leitura propostas por Marcuschi ${ }^{34}$ ( $\mathrm{s} / \mathrm{d}$ : 95 ), segundo as quais, a leitura compreende uma atividade que envolve elaborações semânticas, pragmáticas, lógicas e culturais.

Sob esta perspectiva, a leitura acontece como um "processo inferencial" que enfatiza, no conjunto de uma série de atividades cognitivas, que concorrem entre si durante a leitura, tão somente um aspecto que se apresenta dependente de uma série

${ }^{33}$ Cf. GARCEZ, Maria Helena Nery. Trilhas em Fernando Pessoa e Mário de Sá-Carneiro. Coletânea de artigos e ensaios.São Paulo: Moraes: Editora da Universidade de São Paulo, 1989, p.43.

${ }^{34}$ MARCUSCHI, Luiz Antônio. Leitura como processo inferencial num universo cultural-cognitivo. In: Leitura: Teoria e Prática, № 5, ano 4. Porto Alegre: ALB/Mercado Aberto, junho de 1985. Publicado originalmente nos Anais do I Encontro Interdisciplinar de Leitura. Universidade Estadual de Londrina, Londrina, 1984. 
de fatores lingüísticos e extralingüísticos, sendo, portanto, algo muito mais complexo que a decifração de um "sentido literal" para o texto, que funciona como:

Uma espécie de estímulo intermediário entre o autor e o leitor, ambos com conhecimentos de mundo e sistemas de referência próprios. Resultado de estratégias e operações que controlam e regulam unidades morfológicas, lexicais, sintáticas e sentidos numa ocorrência comunicativa, o texto submete-se a estabilizadores internos e externos para formar uma unidade de sentido (MARCUSHI, s/d: 99).

\subsection{Hipóteses}

Repensando a complexidade da matéria desta tese, o caráter extremamente teórico que a envolve e a multiplicidade dos caminhos epistêmicos que percorremos para a defendermos, julgamos encontrar suporte, extremamente atualizado, para as nossas inquietudes, no teórico de Crítica Literária, Alfredo Bosi, autor da obra $O$ ser e o tempo na poesia, editado pela Companhia das Letras, em 2004.

Apropriando-nos até mesmo da palavra "repensando", com a qual Bosi (2004: 9) inicia o prefácio, intitulado Poesia e historicidade, da sua obra, através do qual questiona sobre "o que faz de um poema poesia, e como este resiste à usura do tempo, roedor silencioso de tantas coisas", levantamos algumas hipóteses sobre teoria e crítica literárias, as quais julgamos servirem de fundamento aos estudos deste teor na literatura mato-grossense.

A princípio, no que interessa à presença de Aquino Corrêa discutindo princípios da crítica literária, no início de século $X X$, em Mato Grosso, fazemos valer 0 pensamento da relação íntima existente entre a obra e a configuração histórico-cultural do sistema, de onde ela emerge, levando em consideração a idéia de que o pensamento crítico do escritor se manifesta enraizado nas fontes que influenciaram a sua formação.

Para explicitar a base do percurso teórico empreendido por nós, retomamos Alfredo Bosi, o qual ao afirmar "o ser e o tempo da poesia", ressalta a necessidade de se compreender uma linguagem de estruturação do texto da poesia, ou seja, o poema. Esta linguagem "combina arranjos verbais próprios com processos de significação pelos 
quais sentimentos e imagens se fundem em um tempo denso, subjetivo e histórico" (2004: 9).

Segundo o crítico, o ser da poesia possui um revestimento externo, que a constitui, através de uma linguagem específica, como um corpo concreto, o qual denominamos "poema". O primeiro momento para a compreensão desta linguagem subordina-se ao estudo analítico do texto, importando considerá-lo como uma forma particular de comunicação e expressão ${ }^{35}$, captando, no texto, o nexo íntimo, o arranjo entre o fluxo sonoro do texto, a sua constelação de figuras e imagens, mais o seu pathos, ou o seu sentido.

O segundo momento desta compreensão importa interpretar e atentar para a presença e o significado da linguagem interna da poesia "no curso do tempo intersubjetivo, social, que é a cultura vivida por gerações de leitores” (BOSI, 2004: 9), fixando o tempo histórico da poesia. Neste caso, a interpretação que é interna, afetiva e arbitrária $^{36}$, penetra o texto e põe à mostra a sua estrutura íntima.

Sob esta perspectiva, delineia-se uma segunda hipótese, a qual nos aproxima teoricamente do pensamento crítico de Nitrini (2000: 158), segundo o qual, somente através da teoria da "intertextualidade", concebida por Julia Kristeva, na segunda metade do século $X X$, recebida por muitos comparatistas como um instrumento eficaz para injetar "sangue novo" nos estudos literários referentes à "fonte" e à "influência", é capaz de dar respostas satisfatórias para se pensar a crítica literária a partir de uma teoria globalizante do texto, englobando, além das categorias estruturais, as suas relações com o sujeito, o inconsciente e a ideologia, em uma perspectiva semiótica, formando um quadro de referência que engloba qualquer outro estudo.

Sob a orientação destas duas hipóteses, tomamos emprestadas categorias conceituais de teorias distintas, procurando fazer a interação destas a fim de promover a especificidade de percursos críticos que nos possibilitam compreender o status estilístico da obra literária, no interior de um sistema.

\footnotetext{
${ }^{35}$ Termos usados por Antonio Candido ao explicitar aspectos sobre comentário e interpretação literária, p. 27, na obra $O$ estudo analítico da poema, editado pela Associação Editorial Humanitas, em 2006.

${ }^{36}$ Novamente, posicionamentos críticos Antonio Candido (Op.cit.) e de Alfredo Bosi (Op.cit.) convergem para através deles explicitarmos esta complexa relação da linguagem poética.
} 
Nesta ótica, Bosi (2004) oferece o argumento que mais significativamente traduz a nossa preocupação crítica de não privilegiar aspectos particulares do texto, não fragmentá-lo, em detrimento do conjunto sistemático que o constitui. Para o poeta pode até se conceber um modelo para sua revelação, mas para o crítico, diante da obra literária, o que deve prevalecer é um conjunto teórico capaz de expressar o elemento artístico.

Quando se mantém alheia a esse encontro de forma expressiva e temporalidade, a teoria do poema arrisca-se a isolar e a sobrestimar determinado estrato do texto, daí resultando esquemas explicativos parciais e excludentes. A história de não poucas doutrinas literárias do século XX ilustra essa forjadura de modelos que, a rigor, dariam conta de apenas um ou outro subconjunto de fenômenos presentes no poema. O texto, assim visto de modo unilateral, ora é reduzido a uma dada estrutura de fonemas da qual teria emergido aleatoriamente o seu sentido; ora é identificado com algumas de suas imagens às quais se emprestaria uma coerência psicológica ou mítica; ora, enfim, é decifrado como alegoria atrás da qual se perfilariam lugares ideológicos do autor ou da sua cultura (BOSI, 2004: 10).

\subsubsection{Influência e intertextualidade}

A princípio, vamos nos ater aos textos do escritor Aquino Corrêa, que marcam com mais força a nossa reflexão sobre a importância da intertextualidade para o desenvolvimento desta pesquisa. Neste sentido, priorizamos aqueles em que se registram as fontes de onde emanam as influências que moldaram a sua formação em particular, e que promovem o debate das interferências entre a questão religiosa e a questão literária, levando em conta os posicionamentos críticos do escritor sobre a poesia, através da elaboração adequada da matéria poética. Para o escritor,

se é verdade que a suspirosa flor da Poesia estiola-se, muitas vezes, no silêncio do peito, à mingua de seiva ou sol, não há tampouco negar que, ao menos seu embrião é aí espontâneo.Quem há que não se tenha sentido poeta, sequer uma vez na vida, muito embora não tenha sabido revelar ao mundo isso? (CORRÊA, 1985 a: 30). 
Colocada em evidência a acepção de influência como "a soma de relações de contato de qualquer espécie, que se pode estabelecer entre um emissor e um receptor" (NITRINI, 2000: 127), percebemos o discurso de Aquino Corrêa perpassado por marcas de outros discursos, as quais apontam para as fontes, que com maior ou menor intensidade, influenciaram a formação cultural do escritor.

Além destas marcas discursivas, também colocamos em evidência as referências diretas que Aquino Corrêa faz a certos contatos que, efetivamente se constituem em presenças que contribuíram na formação do perfil crítico do escritor, como é o caso das referências feitas ao Papa Leão XIII (1810-1903), e ao padre e historiador René François Rohrbacher (1789-1856).

A princípio, as referências suscitam-nos a distinção necessária entre os espaços sociais ocupados pelo sujeito e a sua formação discursiva. Claro está que não pretendemos priorizar aspectos referentes a estas figuras, senão até o ponto em que eles traduzem uma influência capaz de explicitar um aspecto inerente ao discurso crítico de Aquino Corrêa.

Assim é que, do Papa Leão XIII, notabilizado na História como o "papa das encíclicas", das quais a mais famosa foi a Rerum Novarum versando sobre os direitos e deveres do capital e do trabalho, e que funcionou, no seio da Igreja, como um marco do início da sistematização do pensamento social católico; e do padre e historiador René François Rohrbacher, autor das obras História Universal da Igreja Católica e $A$ Vida dos Santos para todos os dias do ano, facilmente se depreende que a referência a estas duas figuras polêmicas pautam os aspectos críticos que objetivam estabelecer foros distintos entre o discurso religioso, o histórico e o literário.

Evidentemente, estamos tratando do discurso crítico literário de Aquino Corrêa, e neste enfoque convém entender a distinção entre discurso literário e língua literária. Neste sentido, Todorov ${ }^{37}$ (1978), ao estabelecer os aspectos do simbolismo lingüístico inerentes a todas as operações da língua, em sua obra Simbolismo e interpretação, propõe uma distinção para língua e discurso bastante aproximada da nossa ótica. Para o teórico,

${ }^{37}$ TODOROV, Tzvetan. Simbolismo e interpretação. São Paulo: 31, 1978. 
A língua existe em abstração, tendo como elementos operatórios de base um léxico e regras de manipulação deste léxico. $O$ discurso é uma manifestação concreta da língua e produz-se necessariamente num contexto particular, em que são levados em conta não apenas os elementos lingüísticos, mas também as circunstâncias de sua produção: interlocutores, tempo e lugar, e relações existentes entre esses elementos extralingüísticos (TODOROV, 1978: 11).

Valendo-nos deste recorte, procuramos priorizar os aspectos que individualizam e formam a imagem do poeta, do teórico e do crítico literário em Aquino Corrêa.

Fazendo valer as raízes que moldam a formação do poeta, em particular, e as que traduzem o discurso crítico do escritor, preocupado em mostrar que a poesia mesmo sendo inata, não se manifesta por si só, afirmamos que concorrem para a manifestação destes pontos de vista, tanto nos poemas como nos discursos de Aquino Corrêa, além dos elementos lingüísticos, conforme orientação de Todorov (1978), as circunstâncias de sua produção, também as relações existentes entre elementos extralingüísticos.

A poesia e os princípios críticos, com que Aquino Corrêa concebe a produção artística, aparecem ao longo das suas obras sempre aliados à idéia de um tempo histórico. Esta constatação nos leva a buscar um conceito de historicidade adequado aos estudos literários.

Neste sentido, mais uma vez, o teórico de Crítica Literária, Alfredo Bosi (2004), oferece a conceituação dialógica para a questão da historicidade, que atende aos nossos interesses. Segundo o teórico, é necessário "vazar os muros de um cronologismo apertado, e ler a obra do poeta à luz da história da consciência humana, que não é nem estática nem homogênea, pois traz em si os trabalhos da memória e as contradições do pensamento crítico". E acrescenta que na história da cultura e, mais ainda, na história de uma prática simbólica tão densa como a poesia, todas as relações do texto têm pertinência, visto que nenhuma fase da história é vivida dos instantes presentes, "na pura e abstrata contemporaneidade sem memória nem projeto, sem as sombras ou as luzes do passado, sem as luzes ou as sombras do futuro" (BOSI, 2004: 13). 
Muito a propósito, convergimos para o posicionamento crítico de Bosi (2004), a crítica de Aquino Corrêa, segundo a qual, mesmo que consideremos a poesia em si mesma, "na sua nobilíssima origem", como "a filha predileta do Altíssimo", ela não é fantasia poética, mas traduz a fórmula feliz de uma profunda verdade filosófica expressa neste formoso hexâmetro 'Deus assiste em nós, quando Ele se agita, aquecemo-nos!'.

Neste sentido, Aquino Corrêa recorre à metáfora da criação do mundo e do homem para figurativizar, juntamente com o nascimento do homem, o nascimento da poesia:

Foi aquela, sem dúvida, a mais augusta cena da criação.Era um novo mundo em miniatura, o microcosmo, que então se criava, tanto mais admirável quanto mais sintético!Foi o portentoso epílogo daquela semana de maravilhas!Foi, em suma, o digno remate daquela estréia da onipotência divina!Quem pudera, com efeito, descrever aqueles membros de argila a se moverem subitamente, por entre a onda rubra e virginal do sangue, transformados em músculos e ossos?Aquela rede melindrosíssima de nervos a se desdobrar pelo corpo todo, como cordas misteriosas de instrumento prestes a vibrar na escala imensa de todas as sensações?Aquele crânio a se iluminar na primeira alvorada do pensamento, qual, havia seis dias, iluminarase o caos ao raiar da primeira luz?Quem pudera, sobretudo, descrever aquele coração maravilhoso a se embalar assim, pela primeira vez, como o palpitante e cálido berço pequenino do amor, essa emoção incompreensível e inefável que nele então vagia? (CORRÊA, 1985 a: 25).

Direcionados pelo olhar comparatista, a teoria da recepção situa determinados posicionamentos críticos de Aquino Corrêa em relação à arte poética, levando em conta a conceituação de "ordem qualitativa" de influência, proposta por Nitrini (2000: 127) que, neste caso, é tratada como o resultado artístico autônomo de uma relação de contato, distinto, portanto, de imitação e de tradução.

Entendendo por "relação de contato o conhecimento direto ou indireto de uma fonte por um autor", percebemos que as citações de Ugo Fóscolo (1778-1827), escritor, poeta, compositor romântico e crítico literário italiano; as de Horácio (65 a. C-8 a. C), poeta lírico e satírico romano, além de filósofo; as de Dante e as de Gonçalves Dias, presentes no discurso crítico de Aquino Corrêa (1985), referenciam uma visão de obra literária como "resultado autônomo", 
produzida com a mesma independência e com os mesmos procedimentos difíceis de analisar, mas fáceis de se reconhecer intuitivamente, da obra literária em geral, ostentando personalidade própria, representando a arte literária e as demais características próprias de seu autor, mas na qual se reconhecem, ao mesmo tempo, num grau que pode variar consideravelmente, os indícios de contato entre seu autor e um outro, ou vários outros (NITRINI, 2000: 127 ).

A influência, nestes casos, revela-se de forma mais sutil na ordem estilística, relacionada tanto à matéria quanto à forma com que o escritor elabora a matéria poética, tornando possível, portanto, diferenciar-se da imitação que denuncia a presença de detalhes materiais do texto literário, tais como os episódios, os procedimentos literários, os tropos e outros traços da composição poética.

A crítica literária é uma prática sistemática, complexa e arriscada, porque o texto literário traz em si marcas de tempos diversos, convergentes na sua produção, assentadas, no poema, através de imagens simbólicas.

Segundo o juízo crítico de Bosi (2004), as imagens simbólicas presentes, no poema, traduzem-se, ora em experiências novas, ora em lembranças de infância, ora em valores tradicionais, ora em anseios de mudança. Sob uma forma ou outra, o poema reflete imagens resultantes de "imbricações de sujeito e trama social" (BOSI, 2004: 14).

Afirmamos, anteriormente, que a crítica literária é uma prática sistemática assentada na análise da matéria, da forma, dos recursos lingüísticos e dos recursos estilísticos, filtrada das influências, da imitação e da tradução. Sob esta bandeira, é conveniente tornarmos bem clara a distinção entre influência, imitação e tradução.

Para este fim, adotamos o modo prático com que Cionarescu ${ }^{38}$ propõe a distinção entre influência, imitação e tradução, recorrendo à definição dos cinco componentes, que o crítico julga assentar a obra literária, sendo eles: o tema, a forma, os recursos estilísticos, as idéias e sentimentos, e a ressonância afetiva.

${ }^{38}$ Cionarescu, estudioso filiado à literatura comparada tradicional. Autor de Princípios de Literatura Comparada. Tenerife, Universidad de La Laguna, 1964, e "Imitation et Influence ou l'insuffisance de deux notions". In: Proceedings of the Fourth Congress of the Icla. Paris, Mouton Co., The Hague, 1966, pp. 917-921. 
Segundo Cionarescu ${ }^{39}$ o tema compreende a matéria; a forma ou molde literário referencia o gênero; os recursos estilísticos expressivos referenciam a filiação do poeta; as idéias e sentimentos, ligados à camada ideológica; e, finalmente, a ressonância afetiva, sendo esta, o registro inconfundível da personalidade artística dos grandes escritores. Estes componentes são os elementos sistemáticos que, assimilados em maior ou menor grau no texto, determinam o grau de influência possível de se perceber em uma obra literária.

Ao se tratar de "grau de influência possível de se perceber", estabelece-se a relação de intimidade de leitura da obra e o leitor crítico. Para explicitar este tipo de relação, Nitrini coloca que quanto maior for o número de elementos aproveitados da obra de um autor por outro, tanto mais ele se aproxima da influência, da imitação, da paráfrase, até chegar à tradução, quando todos os elementos são considerados" (NITRINI, 2000:129-130).

Levando em conta esta relação de assimilação, estabelecemos as influências que moldam o discurso crítico de Aquino Corrêa.

Nesta ótica, afirmamos que, a priori, a alusão ao Papa Leão $X I^{40}$ e ao historiador Rohrbacher, reflete a ressonância afetiva, traduzindo-se na obra literária como um produto resultante das vivências culturais do poeta, independente do seu lugar social, e funciona como que uma explicação para o fato de um bispo dedicar-se à arte poética:

Não nos deslembra, é verdade, que exatamente a este século fora reservada a glória singular de ser cantado, em seus albores, pela harpa, não de um bispo, mas de um Bispo dos Bispos. Foi este o grande Leão XIII que, das alturas olímpicas do Vaticano,

\footnotetext{
${ }^{39}$ Fonte: In: NITRINI, Sandra. Literatura Comparada: história, teoria e crítica. 2. ed. São Paulo: Edusp, 2000, pp. 129-130.

${ }^{40}$ Papa Leão XIII, nascido Vincenzo Gioachino Raffaele Luigi Pecci, em 2 de março de 1810, em Carpineto Romano, na Itália. Notabilizou-se, primeiramente como popular e bem sucedido Arcebispo de Perugia, o que o conduziu à sua nomeação como Cardeal, em 1853.Em 20 de fevereiro de 1878, foi eleito sucessor do Papa Pio IX. Há determinados aspectos que sustentam um perfil de renovador do Papa Leão XIII: foi o primeiro Papa a aparecer num filme; é comum a referência às suas doutrinas econômicas, nas quais argumentava a falha do capitalismo e do comunismo. Ficou famoso como o "papa das encíclicas", das quais a mais famosa, e Rerum Novarum, de 1891, sobre os direitos e deveres do capital e do trabalho, e marcou o início da sistematização do pensamento social católico, chamado de Doutrina social da Igreja Católica, documento que influenciou a criação do 'corporativismo' e da 'democracia cristã'.Em sua carta apostólica de 1899 Testem Benevolentiae condenou a heresia chamada 'americanismo'. Fonte:www.wikipedia.org/wiki/papa-Le\%c3\%a30-XIII.
} 
transfigurado por ele em um como Parnaso cristão, ombreando na forma com o Venusino(alusão a Horácio, poeta nascido em Venúsia, na Itália.), e de muito, levando-lhe a palma na sublimidade do pensamento, entoou 0 derradeiro carme secular.Contudo, poder-se-ia objetar que a poesia do venerando vate nonagenário, já quase de todo espiritualizado, é, por assim dizer, mais angélica do que humana.Parece antes um eco de celestes harmonias a cair limpidamente sobre a terra.Ele canta à passagem do século das luzes, com a mesma religiosa solenidade de Moisés, à passagem do Mar Vermelho (CORRÊA, 1985 a: 22).

A referência ao Papa Leão XIII traduz o pensamento crítico de Aquino Corrêa de que, no processo de elaboração do objeto estético, entram em concorrência aspectos que revelam a "ressonância afetiva" ou "o registro inconfundível da personalidade artística" do poeta filiados aos princípios básicos da sua formação, respondendo à tensão e à ambigüidade com que muitos críticos se defrontam diante do caráter de transcendência e sublimidade da poesia e a formação racional do poeta. Neste sentido, percebemos o pensamento crítico do escritor de que a poesia se realiza através da língua e dos recursos que esta oferece para que se realize tal efeito, mas que "só a filosofia cristã responde satisfatoriamente a essa interrogação impetuosa da alma do poeta":

A sua Musa, em geral, é toda hierática, e o próprio idioma latino, em que versejou, empresta-Ihe esse não sei quê de litúrgico e sagrado, que bem condiz com a gravidade do seu augustíssimo caráter. A poesia, em vez, que aí vai, assim vazada nos moldes vivos e palpitantes de uma língua mais afeita, pelo menos hoje, ao requebro de cancioneiros galantes, do que ao ritmo grave dos saltérios; uma poesia, sobretudo, que talvez não desça do céu à terra, mas procure apenas subir da terra ao céu, não parece hoje, por ventura, indigna, não só das preocupač̃ões, mas até mesmo dos lazeres literários de um Bispo? (CORRÉA, 1985 a: 22).

A concepção de que a "filosofia cristã responde satisfatoriamente aos anseios do poeta", é reforçada pelo escritor na alusão feita à observação do historiador 
Rohrbacher ${ }^{41}$, que, em seus estudos referentes à vida dos santos, falando do século $\mathrm{XVI}$, considerava coisa muito notável, pois ao mesmo tempo que "Portugal, Espanha e Itália produziam grandes santos, produziam também grandes poetas" (CORRÊA, 1985 a: 27).

Ainda nesta concepção que busca nas fontes uma explicação para o fenômeno literário, encontramo-la também em Own Aldridge, citado por Nitrini (2000: 130), o qual, no âmbito dos estudos crítico-literários, interessa-se pela funcionalidade das influências. Segundo o pensamento crítico do teórico Owen Aldridge $^{42}$, a obra literária é reveladora de uma filiação intelectual, que, nos estudos comparados, ajuda a perceber certos aspectos da obra de um autor que não poderiam ter existido se ele não tivesse lido a obra de um autor que o precedeu, bem como no sentido de que somente estas relações de influências ajudam a crítica literária a responder "por que um escritor exprime um pensamento ou um sentimento daquele determinado modo" (NITRINI, 2000:130).

Assim, adotamos este encaminhamento metodológico que parte pelo viés da 'ressonância afetiva', proposta por Cionarescu, somado ao caráter de funcionalidade da influência na compreensão da obra literária, proposta por Aldridge (In:NITRINI, 2000:130), para mergulharmos na proposta de determinarmos o lugar, onde objetivamos inserir os postulados teóricos de Aquino Corrêa no campo dos estudos sobre as influências dentro das coordenadas vigentes dos estudos comparatistas, isto é, "agora não mais dominados pela mentalidade genética do século XIX, mas caracterizado por campos de estrutura de pensamento" (NITRINI, 2000: 130), que passaram a dominar a partir do século XX.

Neste sentido, segundo Guillén (1985), nos estudos comparatistas, trabalha-se com duas acepções de influência: uma, como parte reconhecível e significante da gênese de uma obra literária, o que a leva à filiação a determinadas escolas literárias; e outra, como presença na obra, de elementos e convenções técnicas, pertencendo ao

\footnotetext{
${ }^{41}$ René François Rohrbacher (França:Langatte, 1789-1856) foi ordenado padre em 1812. Foi membro da Congregação de São Pedro, onde dirigiu a cadeira dos estudos filosóficos e teológicos. Sua obra principal foi História Universal da Igreja Católica, obra escrita dum ponto de vista apologético que contribuiu muito com a extirpação dos galicismos da igreja na França. Escreveu também a obra $A$ vida dos Santos para todos os dias do na, 6 volumes, publicados em Paris, em 1853.Fonte:http:/fr.wikipedia.org/wiki/ren\%C3\%A9-Fran\%C3\%A7ois-Rohrbacher.

${ }^{42}$ Cf.Nitrini, op.cit. p.130.
} 
equipamento do escritor e às tradicionais possibilidades de seu meio, diretamente ligadas ao ato criador.

São estas hipóteses que nos levam a relacionar os aspectos mais relevantes herdados da poética clássica que julgamos resistirem ao tempo e sustentarem sistematicamente o pensamento crítico de Aquino Corrêa.

\subsection{Intelectualismo}

Para o desenvolvimento deste estudo, na perspectiva comparatista, procuramos não deixar dúvidas sobre a relevância que atribuímos à reflexão e à cultura intelectual. Neste sentido, apoiamo-nos no juízo crítico de Aguiar e Silva (2000: 518), segundo o qual, "o fenômeno poético na estética clássica, não se divorcia da reflexão e da cultura intelectual".

Através deste direcionamento, que, a priori, interessa à crítica literária, a razão e o bom-senso não se divorciam e têm dupla função no processo criativo, respectivamente, impedem que o poeta caia nos caprichos da imaginação e nos absurdos da fantasia, e funcionam como reguladores da faculdade crítica que esclarece o poeta na criação da obra e orienta o leitor crítico na apreciação das composições literárias.

Aquino Corrêa (CORRÊA, 1985 a: 24) ressalta o caráter eminentemente clássico da sua visão sobre o fazer poético e não se desvincula das inovações provocadas através de um comprometimento com a arte poética, no sentido de que esta não se transforme em uma "carta de alforria", que dê ao poeta as mais descabidas licenças, prescindindo do bom senso, ainda que no campo da criação artística (ficção):

Explica-se, talvez: é o predomínio da paixão e da fantasia na alma do poeta, que sofre de inconstância e volubilidade dos seus ideais. Mas não se justificam, a paixão e a fantasia, que divorciadas da razão, não passam de loucas varridas. O poeta não deixa de ser homem, e o homem não é nem paixão nem fantasia: é, sobretudo, a razão. Fora daí, pode haver nefelibatismo, boêmia, pessimismo, decadentismo, isto é, extravagâncias e loucuras que tanto valem, mas nunca a genuína e virgem poesia. Esta acaricia ideais muito mais verdadeiros e nobres. O belo, que ela doidamente namora, é e será sempre, 
qual o definiu o gênio de Platão, o esplendor da verdade (CORRÊA, 1985 a:,24).

Persistentes na hipótese de que os conceitos de influência e de recepção literária respondem por uma parcela significativa dos estudos sobre crítica literária, adotamos a afirmação de Nitrini (2000:137), de que Cláudio Guillén foi o único estudioso de literatura comparada que procurou estabelecer uma distinção entre influência, relacionada à criação, e influência, como conceito operacional da teoria literária, para dar coerência ao nosso percurso metodológico.

Atentos a esta distinção proposta por Guillén, concluímos que o que o teórico propõe é um percurso metodológico perfeitamente coerente com sua visão teórica a respeito da influência. Ora, para o estudioso, "as incitações genéticas constituem parte da experiência psíquica do escritor, enquanto similaridades textuais pertencem à realidade da literatura" (In: NITRINI, 2000: 137).

Detalhando esta linha teórica proposta por Guillén (1985), vemos que o estudo das influências contém duas fases muito diferentes, porém inseparáveis: na primeira fase, faz-se a interpretação de fenômenos genéticos que relacionam obras, autores e literaturas; e a segunda fase, que é analítica, textual e comparativa, ocorre no nível do texto, portanto inteiramente dependente da primeira fase para revelar a significação particular da obra e o seu conseqüente funcionamento no interior do sistema literário de onde ela emergiu.

Efetivamente, o intelectualismo clássico interessa à crítica literária, tanto ao poeta quanto ao crítico, quando é revelado como produto no fenômeno da criação artística.

Herdeiro de uma tradição teórica germinada nos tempos de Aristóteles e de Horácio, Aquino Corrêa coloca o saber e o trabalho de correção da linguagem como fatores essenciais à criação poética, negando, assim, "a concepção platônica e neoplatônica do ato criador poético como manifestação de uma "loucura" ou de um "furor divino"(AGUIAR \& SILVA, 2000: 519).

Aquino Corrêa, perseguindo os moldes do classicismo, considera a inspiração, o gênio natural, a origem divina da poesia, porém, não a aceita desvinculada de um 
sólido saber e de uma arte apurada na lição dos clássicos. As regras, neste caso, funcionam como elementos que dão corpo e consciência ao processo criador, impondo, portanto, "clareza mental e ordenação artística à feitura do poema",; "o fenômeno poético não se divorcia da reflexão e da cultura intelectual" (AGUIAR \& SILVA, 2000: $518)$.

A partir do Classicismo, procuramos entender a filiação de Aquino Corrêa filiado a uma concepção teórica de crítica literária de que cada gênero, cada forma literária possui as suas regras específicas de funcionamento, relativas ao conteúdo, à matéria poética e à forma de como este conteúdo é elaborado, tendo à disposição elementos estruturais que moldam o estilo particular de cada escritor, no interior de um sistema literário.

Horácio, Virgílio, Dante, Gonçalves Dias e Rhorbacher? Uma profusão de nomes ou uma série de relações intimamente estabelecidas através das unidades reflexivas da língua?

Estas criteriosas observações de Aquino Corrêa estabelecem as relações de pertinência entre o autor e o leitor no que se refere à forma e à matéria do fazer poético.

Os postulados teóricos de Guillén (NITRINI, op.cit.: 137) subsidiam a hipótese que defendemos em relação às referências que Aquino Corrêa faz a estes escritores no interior de seus discursos. Para nós, estas referências são determinantes do posicionamento crítico do escritor diante do campo das influências que orientam o escritor na elaboração do objeto estético e no papel desempenhado por este no interior de uma cultura.

A princípio, as referências feitas por Aquino Corrêa determinam as influências que moldaram o perfil do poeta, cuja formação se assenta na esfera do caráter divino que o mesmo atribui à poesia.

Para dar sustentação a essa visão, o escritor recorre à cena da criação do homem (CORRÊA, 1985 a: 25), e através dessa metáfora da criação, figurativiza a essência da poesia, ou a "alma da poesia" "como um suspiro d'alma que vivifica o homem, e, não o exclui da circulação consciente no meio sócio-cultural,

Quando este suspiro é tão profundo e impetuoso que se não pode conter, mas se irrompe e se incorpora, quer na palavra igualmente 
rija que plástica de um bloco de mármore ou granito; quer na palavra colorida de uma tela; quer na palavra cantante do pentagrama,quer, enfim, na palavra, ao mesmo tempo, cantante, colorida e plástica do verso, temos, então, a ARTE, temos a escultura, a Arquitetura, a Pintura, a Música, a Poesia. Em cada homem que vem a este mundo, renova-se a cena paradisíaca. Recebe ele na fronte a inspiração, que o destina ao Infinito. E é a luz desse Infinito que o envolve todo e deslumbra, com a réstia fulgurante dos seus três raios divinos, A Verdade, o Belo e o Bem (CORRÊA, 1985 a: 25).

Este enfoque nos aproxima de uma concepção de crítica literária estritamente apoiada no estudo analítico do poema, configurando o fazer poético na fronteira de duas belezas, a beleza da forma e a beleza da matéria, ambas trabalhadas no âmbito da estrutura visual e da estrutura sonora do poema, através das unidades expressivas do mesmo.

Vista sob este ângulo, a razão ou a verdade aparecem como o "bom-senso", espécie de mediador que impede que o poeta caia nos "caprichos da imaginação e nos absurdos da fantasia", afastando-o da faculdade crítica que determina o lugar do poeta na criação da obra e que guia o leitor na apreciação da obra literária (AGUIAR \& SILVA, 2000: 518)

Este culto à razão pode significar a atrofia à imaginação para muitos à sua época, mas não o é para Aquino Corrêa que o considera responsável pelo equilíbrio (Cf. Aguiar e Silva, 2000: 520), pela sobriedade densa e pela claridade mental que oferecem as grandes obras da literatura clássica.

O fenômeno poético, pensado por Aquino Corrêa, persegue o que a estética clássica prevê para a literatura, ele não se divorcia da razão, da reflexão e da cultura intelectual. 


\section{CAPÍTULO 4}

\section{Traços precursores: convenção, tradição e originalidade}

E ninguém deve olvidar que Dom Aquino no seu infindável trabalho de edificação religiosa tivesse, alguma vez, repudiado as possibilidades divinas do mundo se assim posso exprimir-me. Ao contrário, moderno e avançado, como sempre, colocou-se dentro do mundo em que vivia - e foi a partir daí que procurou, desveladamente, conspirar a favor da eternidade. (João Antônio Neto $^{43}$, Cuiabá, 2001: 13).

Belo é o que nos arranca do tédio e do cinza contemporâneo e nos reapresenta modos heróicos, sagrados ou ingênuos de viver e de pensar. Bela é a metáfora ardida, a palavra concreta, o ritmo forte. Belo é o que deixa entrever, pelo novo da aparência, o originário e o vital da essência (BOSI, 2004: 131).

43 João Antonio Neto, é o autor dos ensaios críticos Dom Aquino, o orador e O Modernismo em Mato Grosso: reencontro com Silva Freire. Cuiabá-MT, 2001. 
Para relatar o nascimento da crítica literária em Mato Grosso, a partir dos posicionamentos críticos de Aquino Corrêa, começamos escolhendo um ponto de chegada, oferecido pelo próprio Aquino Corrêa: "deixando assim a filosofia do belo, tão rica, aliás, de transcendental poesia, contemplemo-lo apenas do prisma literário, único que, nesta hora, aqui nos ocupa e interessa" (CORRÊA, 1985 b, v. I tomo II: 18).

Adotamos um caminho simétrico a partir da biobibliografia do escritor, porque nos parece que nela encontramos o embrião do estilo do poeta e dos postulados teóricos da crítica literária na história da literatura mato-grossense. Uma vez encontrado este embrião, seguimos as influências que, explícitas ou implicitamente, Aquino Corrêa exerceu sobre os escritores críticos seus contemporâneos ou os seus sucessores.

Nosso percurso, portanto, enxerga o relativismo da autonomia do texto literário, da liberdade do poeta, da influência do comportamento crítico de um autor em seus sucessores, que encerram e sintetizam em maior ou menor grau, em seus escritos, as idéias dos valores tradicionais anunciando o nosso modernismo.

Reforçando esta rubrica, Bosi (2004), citando Hegel, nos diz que "é exatamente a liberdade da produção e das configurações que fruímos na beleza artística", e acrescenta que:

Da noção de encontro dos tempos tanto pode emergir uma teoria retórica que vê o texto como variante de um topos extraído do cânon literário (ou seja, o passado regendo o presente), como uma leitura do poema como expressão poliédrica, em parte herdada, em parte inventada, pela qual o poeta enfrenta a rotina retórico-ideológica usando livremente, para seus fins, instrumentos da tradição (BOSI, 2004: 14-15).

Para encontrar, em algum lugar do passado, uma reflexão que simultaneamente nos contemplasse com um discurso de atualização da tradição, um discurso que não faça pensar o tradicional como um fenômeno marginal, estático no tempo, buscamos João Antonio Neto, que através dos ensaios críticos Dom Aquino, o orador e 0 Modernismo em Mato Grosso: reencontro com Silva Freire, lançados em Cuiabá, em 2001, nas comemorações dos oitenta anos da Academia Mato-Grossense de Letras Cuiabá-MT, 2001, promove este encontro dos tempos, traduzindo, através da crítica, as 
diferentes formas de enfrentamento da "rotina retórico-ideológica, usando, para seus fins, instrumentos da tradição" (In: BOSI, 2004: 15).

\subsection{Convenção, tradição e originalidade}

Uma vez pensadas as possíveis influências que, explícitas ou implicitamente, Aquino Corrêa exerceu sobre os escritores críticos, seus contemporâneos ou sucessores, procuramos detalhar, com maior objetividade, as formas como a estética da recepção contribui para a renovação dos estudos de influências.

Em sua Literatura Comparada: história, teoria e crítica ${ }^{44}$, Sandra Nitrini (2000), respondendo ao questionamento sobre a contribuição da estética da recepção para a renovação dos estudos de influências, afirma que:

Com seu objetivo de substituir a historiografia literária substancialista, fundada no estudo da obra e do autor, por uma historiografia voltada para o leitor, a estética da recepção abre perspectivas para que a influência já não se explique mais causal e geneticamente de obra a obra, de autor a autor, de nação a nação, mas como resultado complexo da recepção (NITRINI, 2000: 181).

Está claro que Nitrini (2000) justifica a sua afirmação, levando em consideração que a estética da recepção pouco avançou, em termos de contribuição metodológica, para um melhor desvendamento da relação entre autor, obra e leitor, no campo comparatista, tendo em vista as dificuldades da operacionalidade de uma das noções mais importantes da teoria da recepção, ou seja, a reconstituição do horizonte de expectativa, que atinge não só o leitor passivo e o leitor reprodutor, mas também o leitor produtor.

Segundo Nitrini (2000:170), a estética da recepção surgiu nos anos 60, em um contexto marcadamente estruturalista, com tendência aistórica, e se transformou numa teoria da comunicação literária, cujo objeto de pesquisa é a história literária, definida

\footnotetext{
${ }^{44}$ Vide: NITRINI (2000) Cap. 2-Conceitos fundamentais(125-182). A seqüência de dados teóricos adotados é de nossa responsabilidade.
} 
como um processo dialético, assentado no autor, na obra e no público. Nesse sentido, os estudos sobre recepção e influência remetem-nos a uma noção de estética que

não se refere nem a uma consciência do Belo nem à antiga questão sobre a essência da arte, mas procura apreender algo sobre a arte por meio da experiência da própria arte, pelo estudo histórico da prática estética que, graças às atividades produtoras, receptoras e comunicativas, está na base de todas as manifestações da arte (NITRINI, 2000: 170-171).

Esta concepção metodológica, que adotamos para desenvolver esta pesquisa sobre o fenômeno literário em Mato Grosso, a partir de Aquino Corrêa, distingue os nossos estudos em função das relações de coletividade assumidas pelo autor, pela obra e pela recepção desta junto ao público. Assim, este tipo de abordagem, que interessa, em particular, à crítica literária, prevê a relação produtiva entre o emissor e receptor, provocando reações de vários modos: "consumir simplesmente a obra ou criticá-la, admirá-la ou recusá-la, deleitar-se com sua forma, interpretar seu conteúdo, assumir uma interpretação reconhecida ou tentar apresentar uma nova" (NITRINI, 2000:171).

Sempre atentos à contribuição da conceituação nos estudos que realizamos, julgamos necessário, para melhor compreender o nosso percurso metodológico, esclarecer o conceito de horizonte de expectativa, conforme o que é proposto por Hans Robert Jauss ${ }^{45}$ (1979), segundo o qual, ele abarca os pressupostos sobre os quais um leitor recebe uma obra, devendo-se distinguir, nestes pressupostos, o horizonte de expectativas intraliterário e o horizonte de expectativas extraliterário.

O horizonte de expectativas intraliterário está implícito nos elementos formais da obra, e é através dele que se dá a "pré-compreensão dos gêneros"e a "contraposição da linguagem poética e prática"; no extraliterário, estão implícitas as relações contextuais que são dadas pelo "mundo vital prático do leitor individual ou dos estratos de leitores”(NITRINI, 2000:171), sendo neste horizonte que se dá a interpretação.

\footnotetext{
${ }^{45}$ Fonte: NITRINI, Sandra. Literatura Comparada: história, teoria e crítica. São Paulo: Edusp, 2000, p. 170. Hans Robert Jauss, segundo Nitrini, é reconhecido como o teórico que melhor formulou o conceito da estética da recepção, cujos aspectos fundamentais desta teoria foram expostos na sua exposição "Estética da Recepção e Comunicação Literária", apresentada no IX Congresso da Associação Internacional de Literatura Comparada.
} 
É através deste enfoque proposto por Jauss (1979), que propõe a recepção diferenciada de um texto literário por leitores contemporâneos e por leitores historicamente sucessivos, que se depreende o "potencial de sentido" com o qual a obra de Aquino Corrêa é recebida, tornando-se depositária de princípios norteadores da crítica da literatura produzida em Mato Grosso.

Adotando este procedimento, prevenimo-nos simultaneamente de duas concepções radicalizantes de recepção da obra literária de Aquino Corrêa: uma concepção subjetivista e relativista que se "legitima por disposições históricas, sociais, literárias, estéticas e pessoais da recepção"; e outra assentada numa "tradição de pesquisas históricas fundamentadas num ideário poético que contempla as noções de fortuna, influência, sucesso, etc" (NITRINI, 2000). E assumimos, através da estética da recepção, um lugar que restitui ao leitor o papel ativo na concretização do sentido das obras, ao longo da história, sempre abertas a novas interpretações.

No auge destas formulações teóricas, retomamos o posicionamento crítico de Nitrini (2000), segundo o qual

a estética da recepção mantém uma concepção dialética: a história das interpretações de uma obra de arte é uma troca de experiências, ou um diálogo, um jogo de perguntas e respostas. Convém lembrar aqui que Jauss, para elaborar suas reflexões, apóia-se, em parte, na estrutura da obra literária de Roman Ingarden, cuja perspectiva central é a de que uma obra é inacabada e ela só se manifesta plenamente por meio da interação texto-leitor" (NITRINI, 2000: 172).

Ao reler Aquino Corrêa, acontece detectar importantes convergências e divergências do poeta, de matriz classicista, com alguns escritores e críticos, de épocas e escolas literárias bem distintas, que podem alterar substancialmente a visão habitual da contribuição deste escritor para a história da poesia em Mato Grosso.

Se na história da literatura produzida no Mato Grosso, já é corrente assinalar-se a presença de Aquino Corrêa como o poeta de formação clássica, assentado na perfeição formal da escola parnasiana, e que encontra na escola romântica a sustentação da sua matéria poética, parece-nos que a referência à influência de seus posicionamentos críticos, na história da crítica literária não tem sido objeto de exploração. 
Opondo-nos à unilateralidade exclusiva de qualquer um desses dois métodos investigativos, quer o que tem uma concepção subjetivista e relativista da obra, legitimada por disposições históricas, sociais, literárias, estéticas e pessoais da recepção, quer o que se assenta numa tradição de pesquisas históricas fundamentadas num ideário poético, que contempla as noções de influência e de fortuna crítica, adotamos a concepção dialética da estética da recepção para acrescentar, à história das interpretações da obra de Aquino Corrêa, os aspectos que representam troca de experiências teóricas que se somam, significativamente, às reflexões sobre a história da crítica literária de Mato Grosso.

$\mathrm{Na}$ fronteira destas duas práticas investigativas, o estudo sobre as influências em Aquino Corrêa, abordando primeiro, o que nos pareceu, de um modo geral, pontos comuns à sua produção poética e aos posicionamentos críticos com que este escritor pensava a poesia produzida em Mato Grosso, leva-nos a buscar, nos conceitos de convenção e tradição, propostos por Guillén, o aporte necessário para entender a literatura enquanto sistema.

Segundo Guillén (In: NITRINI, 2000:137), convenção e tradição funcionam como "sistemas", cujo principal fator unificante são o costume aceito e os instrumentos que, mediante os estudos de literatura comparada, vão dar conta da inserção da obra do escritor, no contexto mais amplo da literatura, e permitir também o diálogo de suas obras com outras obras, autores e literaturas; para depois, numa segunda parte, passar ao estudo particularizado da língua literária em face do discurso crítico do escritor. Para Guillén,

as tradições constituem convenções que supõem ou conotam seqüências temporais.Tanto num caso como no outro, o que está em jogo é o uso coletivo, e não o impacto singular ou a forma concreta de um processo de transformação histórica.Uma constelação de convenções determina o meio de expressão de uma geração literária- o repertório de possibilidades que um escritor compartilha com seus rivais vivos. As tradições supõem 0 conhecimento, por parte dos escritores, de seus antepassados.Tais coordenadas não apenas regulam a composição de uma obra, como também se fazem presentes no processo de leitura (In: NITRINI, 2000: 138). 
A noção de convenção e de tradição não mata a de originalidade virtual de um sistema particular ou geral. Não teríamos como apresentar este estudo crítico sem recorrer ao conceito de originalidade, como parte de um ideário ligado ao comparatismo tradicional, que nos leva a uma perspectiva teórica e classificatória do que seja original em Aquino Corrêa e em suas obras.

Neste sentido, adotando o postulado crítico de Anna Balakian ${ }^{46}$ (1966), segundo o qual, a duplicidade de sentido da palavra original, que ora nos remete ao que é relativo à origem (do francês - originel), ora nos remetendo à novidade (também do francês - original), é possível determinar o lugar discursivo de Aquino Corrêa, no interior dos estudos literários de Mato Grosso, comportando-se como original, quando o consideramos ligado às origens responsáveis pela formação de uma consciência crítica da literatura mato-grossense como um sistema literário singular e particular, e também original, como uma novidade presente, o ser iluminado que, a princípio, abriu caminho, e procura ganhar, na história dos estudos literários do Mato Grosso, o lugar de precursor.

De modo geral, Aquino Corrêa representa, conforme orienta Nitrini (2000:142), aquele que lançou, sem respostas imediatas, problemas sobre crítica e teoria literárias, e sobre os procedimentos críticos para a concepção crítica de uma literatura produzida em Mato Grosso.

Nesta linha teórica do original ligado à origem e do original ligado ao novo, percorreremos, tanto na obra de Aquino Corrêa como na fortuna crítica do escritor, especificamente, os textos que nos dão suporte para responder as questões ligadas à originalidade da matéria e da forma da poesia na literatura mato-grossense.

Para Balakian (1966), o processo de configuração de uma obra literária é sutil e complexo. Na obra, o espírito original (de origem), acha-se abafado por uma convenção na fonte, onde há uma originalidade, o inusitado, uma forma criativa particular registrada no seu interior, o qual pode ser imitado mediante uma outra convenção que percebe o original, enquanto novidade, e quebra esta convenção, inspirando-se nela.

\footnotetext{
${ }^{46}$ Autora da comunicação "L'originel et l'original - Nuance linguistique, distance poétique", apresentada no IV Congresso da Associação Internacional de Literatura Comparada, realizado em Friburgo, em 1964, e publicado, posteriormente, na obra Proceedings of the Fourth Congress of the Icla. Paris, Mouton Co. , 1966, (In: NITRINI, 2000: 139).
} 
Perseguindo esta formulação, Balakian (1966) propõe quatro meios de ruptura com as convenções: primeiro, o desvio ou a deformação da convenção; segundo, a reversibilidade; terceiro, a sátira da convenção e, por último, o aperfeiçoamento de uma técnica que situa uma idéia já conhecida num clima lingüístico propício (In: NITRINI, $2000: 142)$. E, é no rastro destes quatro meios de ruptura com as convenções que procuramos traduzir Aquino Corrêa como uma ponta de novidade, distinguindo-o de outros intelectuais da sua época, em função das suas relações críticas e teóricas com o fenômeno estético.

A princípio, como caudatário de uma literatura de inspiração clássica, os poemas de Aquino Corrêa anunciam certo grau de ruptura com as convenções, ocorrendo através da reversibilidade das formas poéticas praticadas pelo escritor.

A reversibilidade ocorre através da transformação da matéria poética, ocorrida por meio de um desvio temático que transporta o poeta para a atualidade do seu contexto sócio-cultural revelando algum grau da originalidade de Aquino Corrêa, que, cultivando, provavelmente, a mais antiga das formas literárias, a poesia, revela a matéria poética, retomando formas poéticas como a ode, a elegia e o soneto, que sobreviveram nas literaturas ocidentais modernas, resguardando características primárias mais ligadas à forma.

Através do arranjo harmônico das palavras, em poemas que se organizam em versos caracterizados pela escolha das palavras ou das unidades lingüísticas, em função dos seus valores semânticos e sonoros, Aquino Corrêa cultiva certas formas que, pelas características formais e temáticas filiam-no ao gênero lírico adotado pelo poeta, bem como determinam o seu estilo individual.

Adotando o princípio de que a linguagem é o veículo utilizado pelos poetas para escrever seus poemas, e que escrever poemas é trabalhar com a linguagem, depreendemos que os gêneros literários adotados por Aquino Corrêa são as várias formas que o escritor assumiu para registrar seus posicionamentos críticos sobre a linguagem literária, registrar a história da literatura produzida por ele, e fazer com que essa linguagem literária signifique o instrumento de conexão entre os diversos contextos literários que estão dispersos nas vozes dos escritores, que influenciaram o universo literário de Aquino Corrêa. 
Evidentemente, nesta linha teórica, estamos considerando o simbolismo lingüístico da língua literária, em acordo com que propõe Todorov (1978: 16), o qual afirma que o fenômeno simbólico não tem nada de caracteristicamente lingüístico, apenas é transmitido pela linguagem, a qual possui procedimentos e normas próprias para esta transmissão. Neste caso, na linguagem literária, os sentidos e as significações são evocados por associações.

Atentos à estrutura da expressão "simbolismo lingüístico", em que "simbolismo" é o substantivo e "lingüístico" é o adjetivo, é pertinente fazermos a distinção entre "símbolo", referenciando o simbolismo da linguagem, e "signo", referenciando o dado lingüístico, para entendermos a intimidade e sutileza desta relação na língua literária.

Segundo Todorov (1978: 17), "a teoria mais divulgada, de Platão a Saussure, não vê outra diferença senão na sua motivação, presente no símbolo e ausente no signo, o significante parece ou não com o significado". O que diferencia substancialmente símbolo de signo é a "motivação" - tipo de associação. O símbolo é motivado, enquanto o signo não é. Assim, o texto literário se desenha como resultado de associações motivadas em diferentes contextos, que podem estar mais ou menos presentes, ou mais ou menos esquecidos no texto. Porém, o texto, o poema, é uma realidade concreta, é a face significante do signo.

Ancorados nesta premissa, registramos que Aquino Corrêa demonstra preferência pelas formas fixas como ode, elegia e soneto, que, segundo o nosso ponto de vista, guardam os contextos das suas origens, mas traduzem um tipo de aproveitamento que soa como originalidade pela voz do poeta e do crítico literário.

A ode e a elegia sobreviveram na poética de Aquino Corrêa, resguardando traços característicos das suas origens sob o ponto de vista da forma e do conteúdo.

A ode, originariamente um poema de forma complexa e variável, surgido na Grécia, onde era cantado com acompanhamento musical, sobreviveu na literatura praticada por Aquino Corrêa, sobretudo, do ponto de vista da forma, guardando o seu caráter lírico e a simetria das estrofes. Sendo composta por três estrofes, correspondentes, no desenvolvimento da idéia do poema, à estrofe, à antístrofe (cantada pelo coro) e ao epodo (conclusão do poema), a ode comportava uma série de esquemas métricos e rítmicos, de acordo com os quais era classificada. 
A título de ilustração, da obra Odes (CORRÊA, 1985 a), onde se registram inúmeros sonetos, hinos e cartas e, constatamos apenas uma composição que resguarda a antiga forma da ode - três estrofes - correspondente ao desenvolvimento da idéia do poema, o qual transcrevemos a seguir:

O MEU LÍRIO

Para uma criança.

Tenho um lírio vicejante, Que na minha alma nasceu

De um beijo de Deus, no instante,

Em que a criou lá no céu.

O sangue da Eucaristia

É orvalho desta flor;

Seu sol - o olhar de Maria,

A Virgem do belo amor.

Hei de amar-te, ó flor tão pura,

Te que me brilhe esta luz;

E, na minha sepultura,

Florirá ao pé da cruz...

Coxipó, 1913.

A forma poética denominada elegia que, na Antigüidade traduzia uma poesia lírica de tom terno e triste, geralmente uma lamentação pela morte de um personagem público ou de um ser querido, aparentada à poesia épica pela sua forma, atravessou épocas e sobrevive como uma forma bastante presente nos poemas de Aquino Corrêa.

Consideramos que a elegia seja a forma poética preferida de Aquino Corrêa dado o seu caráter formal porque possibilita ao escritor fazer a elaboração da matéria através de digressões moralizantes destinadas a ajudar os ouvintes ou os leitores a suportar momentos difíceis.

Como a nossa tese objetiva defender o discurso crítico de Aquino Corrêa, que traduz considerações sobre princípios fundamentais de teoria e crítica literária nos estudos da literatura mato-grossense, furtamo-nos em apresentar estudos analíticos mais detalhados dos poemas do escritor, limitando-nos, portanto, à transcrição de alguns textos ou fragmentos textuais que mais significativamente nos aproximam da 
idéia de reversibilidade, quando através da elaboração da matéria poética, ocorrida por meio de um desvio temático, o poeta é atualizado no seu contexto sócio-cultural, revelando algum grau da originalidade, assentado no processo digressivo que the possibilitou expressar-se na sua atualidade através de uma forma tradicional.

É o caso do poema Elegia, escrito em 1908, quando o poeta estava em Genzano (Roma), e escreveu-o a um amigo, lamentando e confortando-o pela morte do pai e da irmã.O poema é composto por dezessete estrofes regulares sendo dezesseis tercetos e um quarteto, com um esquema de rimas alternadas, dos quais transcrevemos oito tercetos e o quarteto que o conclui.

\section{ELEGIA}

A um amigo.

Um ano! E quantas lágrimas a fio

Depois que o arcanjo pálido da morte

Bateu à porta do teu lar sombrio!

E em dois meses (quem há que te conforte?)

Apagou, insensível a teus prantos,

Duas vidas, dois astros do teu norte!

Oh! Um pai e uma irmã! Que amores santos!

Quantas rosas, da vida entre os rigores!

$\mathrm{E}$, entre as rosas da vida, que de encantos!

E viste-os definhar qual duas flores,

Que a asa selvagem do gavião sacode,

Ao pressentir na relva os caçadores.

Ai! Quem tal caso recordar-te pode,

Sem que dos olhos e da lúgubre alma

Em cascatas a lágrima lhe rode?

Feliz então quem ergue o olhar com calma,

E além do azul, que vão beijar as garças,

Vê dos seus caros a celeste palma!

E tu feliz que, em tão horrentes sarças,

Pudeste ouvir o canto da esperança,

A boa fada de pupilas garças:

"Aqui só jaz o corpo. Além descansa

No céu a cândida alma. Ambos um dia

Abraçarás na bem aventurança!" 
(...)

Que a pátria azul do amor é o paraíso,

pois sobre a terra, angusta e passageira, esvai-se ao fim o mais sincero riso

Neste estúpido rictus de caveira!

Genzano (Roma), 1908.

Mas, a forma mais reveladora de uma atualidade do poeta Aquino Corrêa é o soneto, se o considerarmos na história de como esta forma poética atravessou épocas e estilos literários, promovendo uma ruptura assentada no aperfeiçoamento de uma técnica.

O soneto teve a sua origem no século XIII, através do poeta de Santa Firmina, Guittone D'Arezzo, que foi o primeiro a adotar aquilo que atravessou o tempo como a melhor forma de expressão de uma emoção, e foi empregada por Francesco Petrarca e Dante Alighieri; atualizada pelas vozes do teatrólogo Willian Shakespeare; por Luís de Camões, para expressar o seu lirismo; pelo poeta russo Aleksandr Pushkin que compôs Eugene Onegin, um poema repleto de sonetos adotados por Tchaikovsky para compor uma das suas óperas; pelo poeta francês Charles Baudelaire, que ajudou a divulgar os versos alexandrinos em Les Fleurs du Mal, até Vivaldi, cantor de óperas, utilizou-se de sonetos.

Finalmente, após aderir ao humanismo e ao barroco, o poema de catorze versos, com dois quartetos e dois tercetos, geralmente decassílabos ou alexandrinos, acabou sendo desprezado pelos iluministas.

No século XIX, ele volta a ser cultivado, com maior fervor, por românticos, como forma de expressão de emoções; por parnasianos, traduzindo, através da sua forma fixa, o postulado máximo da arte pela arte; e por simbolistas, através da valorização de unidades formais geradoras de sinestesias e de aliterações; sobrevivendo ao nascimento da forma que melhor traduz a liberdade de expressão do movimento modernista - o verso livre - única ruptura da forma que viria em seguida até os dias atuais.

$\mathrm{Na}$ estrutura lógica e formal do soneto há uma proposição, o seu desenvolvimento e uma conclusão, constituída pelo último terceto denominado de 
"chave-de-ouro", porque se constitui como decodificadora do significado global do poema.

Referindo-nos ao soneto, tanto nos seus elementos formais, como nas unidades expressivas da matéria que o constitui, inferimos, através das referências diretas que Aquino Corrêa faz a Petrarca e a Dante Alighieri, como "cantores do amor", o modo particular como Aquino Corrêa interpreta a relação simbólica do amor, motivado pela presença da sua amada, na expressão poética, através do soneto: "para celebrar esse amor, aquela poesia tão original e gentil que imortalizou os cantores de Beatriz, Laura ou Marília (...) (CORRÊA, 1985 a: 23)".

O que se pode inferir desta referência é que a originalidade em Aquino Corrêa provém da técnica, da qualidade sutil com que o poeta liberta o seu romantismo, adentrando por uma temática, que poderia parecer indigna de um bispo-poeta, o amor!

A temática sobre o amor adeja o discurso do escritor e insere a presença feminina em seus poemas. É o que exemplificamos com o soneto Na capela da Virgem, escrito em 1899, em Cuiabá, quando o poeta contava com quatorze anos de idade, período áureo da adolescência.

Do órgão por entre a casta melodia, Cantam mil vozes oração divina;

Arde e se espalha essência pura e fina,

Que o templo em nuvens ao Olimpo envia.

Em claro sólio alteia-se Maria,

Sobre as mais alvas flores da campina,

Qual nos jardins a rosa peregrina

Dentre as boninas ergue-se e extasia!

Mil invisíveis serafins divinos

Seus amores ofertam-Ihe ferventes...

E neste ambiente puro, encantador,

Desfaz-se a lira em sacrossantos hinos,

A alma se exala em orações ardentes,

Queima-se o peito em acendido amor!

A originalidade em Aquino Corrêa não consiste em falar do amor carnal, do amor das aparências materiais, que é, pela voz do crítico, o que existe de mais falso e banal, a "suprema degradação" do homem, o que o poeta canta é "um amor que é a suprema 
elevação do homem" (CORRÊA, 1985 a: 33), e que nos interessa, em particular, porque manifesta, através dos poemas do escritor, a temática do amor ligado à figura feminina.

Em seu discurso sobre o amor e a figura feminina na poesia, Aquino Corrêa (1985 a: 33) enaltece o amor e a mulher, através da recuperação das personagens femininas que ilustraram os poemas de Francesco Petrarca, de Dante Alighieri e Tomás Antônio Gonzaga.

Em /l Canzoniere, de Petrarca, Aquino Corrêa destaca os recursos metafóricos e o lirismo erótico dos sonetos dedicados a Laura de Novaes, por quem o poeta nutria um amor platônico; em Vita Nuova, primeiro trabalho literário de grande importância de Dante Alighieri, a crítica de Aquino Corrêa volta-se para o amor impossível, cantado em versos para Beatriz (provavelmente Beatrice Portinari), imortalizada em vários sonetos, pelo autor da Divina Comédia; mais aproximado, Aquino Corrêa, observa a simplicidade do amor eternizado na figura de Marília. O crítico literário observa os caracteres nitidamente árcades, embora já se vejam alguns elementos da escola romântica, tais como a idealização do objeto amado, com que o poeta Tomás Antônio Gonzaga, na obra Marília de Dirceu, canta a beleza da mulher, ou melhor, da sua pastora.

Para Aquino Corrêa, o amor é a alma da poesia, (...) é a poesia eterna do coração humano. O poeta faz da linguagem poética um veículo para demonstrar a verdadeira técnica da composição romântica do amor, e é o soneto, a forma poética que mais significativamente traduz este sentimento.

Nenhum termo há, de que tanto abuse a linguagem humana, forçando-o numa confusão habitual e detestável, a significar idéias infinitamente desencontradas.Existe, de fato, o amor que é a suprema elevação do homem, e outro amor que é a sua suprema degradação.Há o amor que é surto radioso do espírito, arrebatado consigo, rumo ao Ideal, o troféu glorioso de uma animalidade transfigurada; mas há outro amor que é a tirania brutal da sensualidade, atascando a razão nos hediondos tremedais da carne.Há o amor que é um cântico de cotovia entre os dourados espasmos da luz nascente; mas há o outro amor que é corvejar voluptuoso do abutre em putrefactos repastos. Há o amor que é o beijo harmonioso de mãe ou esposa casta; mas há outro amor que é o beijo verminado e soturno dos lupanares sombrios. Há um amor que é como a alvorada virginal do Evangelho na alma adolescente do discípulo predileto; mas há o outro amor que é como aquela noite imensa da alma tenebrosa de Judas. Há um amor que é a vida, e outro que é a morte.Há um amor que é 
sorriso infinito, e outro amor que é a infinita miséria.Há, enfim, o verdadeiro e o falso amor (CORRÊA, 1985 a: 34).

Estruturados nos posicionamentos críticos de Aquino Corrêa, pressupomos que a sincronização da língua literária cria a forma e a norma que convêm tanto à estruturação dos temas e as suas variações, quanto das formas de estruturação expressiva do poema.

Ancorados nessa pressuposição, afirmamos que a forma e o conteúdo adaptados para a expressão do pensamento mais que ideológico do poeta, assegura o caráter de extrema originalidade com que cada artista explicita, num poema, a poesia, no coração do tema mais banal.

É neste movimento de sincronização da língua literária que o poeta Aquino Corrêa cantou os temas mais diversos; transformou-os em matéria poética sob as mais diversas formas, buscadas na tradição, conforme se verifica em Odes (1985), quando canta os sonhos, os valores e os heróis de sua infância e adolescência; em Terra Natal (1985), revelando os ecos da natureza, dos fatos históricos, dos homens e das tradições; e, em sua Nova et vetera (1985), com os "versos de outrora", os "versos de agora", os "hinos e canções", as traduções e as versões, o poeta, fiel ao seu estilo, cantou as travessias do tempo em matérias e formas variadas, e, sobretudo, o comprometimento do poeta com a arte literária, através do soneto "Arte Poética", escrito em 1926:

Se queres, poeta, que tua alma cante, Rumo ao céu, como a alada cotovia, Dá-lhe as asas da prece ardente e pia, Ao sol da fé radiante.

Estuda, estuda a fundo, noite e dia, O belo idioma límpido e cantante, Para engastar a rima de diamante, No ouro velho da clássica harmonia.

Deixa depois teu estro voar, sem tolas Preocupações de mestres, nem de escolas:

Fale-te o próprio Deus, no amplo universo!

Vai assim o ideal que é a formosura Do espírito a brilhar, eterna e pura, $\mathrm{Na}$ áurea beleza plástica do verso! 
Partidários de uma crítica literária que se assenta no estudo analítico do poema, para verificar o grau de envolvimento do poeta com os elementos que estruturam a obra literária, em particular, e verificar de que forma o escritor se deixa envolver pelas influências, resultando em algo diferente, além da mera convenção, algo particular no interior de um sistema, interessa-nos "como se deu a alquimia da convenção", ou, em termos mais modernos, de que maneira o poeta fez a absorção e a transformação dos elementos recebidos de outros.

Desta forma, perseguindo o raciocínio crítico de Balakian (1966), concluímos que

A fortuna crítica de um escritor ilumina o caráter de sua obra e nisso se encontra as vantagens dos estudos de doxologia ${ }^{47}$. Por outro lado, os estudos das influências na obra deste escritor enriquecem a apreciação do crítico não sobre o que brilha, mas sobre aquele que recebe o brilho (In: NITRINI, 2000:144).

Nesta linha teórica que privilegia a preservação das fontes e das influências implícitas, no discurso de Aquino Corrêa, e nos trabalhos críticos apresentados sobre o poeta, vamos nos localizar neste universo de literatura de matriz clássica que não prescinde de uma formação intelectualmente bem estruturada para a possível identificação do objeto novo.

\subsection{Aspectos sobre a forma e o conteúdo poéticos em Aquino Corrêa}

Na época das comemorações dos oitenta anos da Academia Mato-Grossense de Letras, o escritor e crítico literário João Antonio Neto (2001:13) publicou os ensaios críticos Dom Aquino, o orador, sobre a oratória de Aquino Corrêa, e O Modernismo em Mato Grosso: reencontro com Silva Freire, sobre aspectos literários que enunciam o modernismo em Mato Grosso.

Coincidentemente, a publicação desses dois ensaios em um único volume, é o que mais de perto se aproxima do nosso intento de mostrar aspectos referentes à teoria

\footnotetext{
${ }^{47}$ Doxologia: do grego dox (o), dóxa, es= glória; crença; opinião.Dox(o)+ log (o)+ia =fórmula litúrgica de louvor a Deus, geralmente ritmada. Ao que interessa no trabalho que desenvolvemos, a doxologia responde pelo caráter das crenças e opiniões vigentes em épocas e períodos distintos.
} 
e à crítica literárias em Aquino Corrêa, no momento em que representa uma passagem, a transição entre uma literatura teoricamente enquadrada nos moldes tradicionais e uma estética que, segundo João Antônio Neto, traz-nos "a inumerabilidade das coisas e de nós mesmos"; a existência de perspectivas ilimitadas de expressão artística; uma perpétua anunciação; a afirmação de que na arte há muito mais realidades do que realidade: "o mundo é múltiplo e plúrimo e, em conseqüência, não pode, nem deve cingir-se a qualquer limitação" (NETO, 2001: 34).

Convém ressaltar, mais uma vez, que o que nos interessa em Aquino Corrêa são os posicionamentos críticos do escritor em relação à matéria e à forma poéticas, que soam como parâmetros para pensarmos criticamente a poesia produzida em Mato Grosso.

Propositalmente, decidimos instalar o poeta em alguma fronteira, recorrendo a ele sempre que considerarmos que seus poemas signifiquem, pelos olhos da crítica literária, alguma ruptura ou transgressão que justifiquem a sentença de João Antônio Neto sobre Aquino Corrêa: “(...) moderno e avançado, como sempre, colocou-se dentro do mundo em que vivia" (NETO, 2001: 13).

É o caso, por exemplo, dos percursos literários de Aquino Corrêa pela história de Mato Grosso. Em uma atitude multidisciplinar, conforme se pode atestar através dos poemas "A Rusga" e "A Retirada de Laguna", o poeta elabora a linguagem literária, utilizando-se de uma forma poética fixa, o soneto, mesclando, na composição deste, o gênero lírico e o narrativo, o discurso histórico e o discurso literário, além de História e Religião.

A Rusga, em Mato Grosso, foi um dos mais precoces movimentos regenciais que ocorreu em Cuiabá, no século XIX, em 1834. Foi um movimento organizado contra os privilégios dos comerciantes portugueses. Apesar de não propor transformações radicais nas estruturas econômicas e políticas, foi uma revolta popular que saiu do controle das lideranças liberais, que haviam se aproveitado do movimento para subir ao poder.

A historiadora Elizabeth Madureira Siqueira, em sua obra História do Mato Grosso: da ancestralidade aos dias atuais (2002), conta, pela versão dos revoltosos, que, 
Dia trinta de maio de 1834, às oito horas da noite, arvorou-se nesta cidade o pendão do patriotismo. Cansados já os bons brasileiros de suportar os insultos dos vis e infames bicudos, já com negaças de vultos mascarados para assassinarem aos membros mais influentes da nossa Sociedade, já com plano para fazerem carniça aos Brasileiros à custa do veneno do dia da posse do Imperador do Espírito Santo, cujo novo emplastro era o bicudo Ramos e Costa, já traçando a deposição do nosso amante Chefe do Batalhão Nacional, enfim, tudo produziu à deliberação de grande pega, e foi principiado como faço ver abaixo. Cidadãos reunidos no Campo do Ourique, oitenta, comandados por Sebastião Rodrigues da Costa, quarenta, e por seu amigo quarenta: meditou-se o cerco do Quartel, e no primeiro assalto, felizmente, apoderamo-nos dele, porque eram todos amigos, que tinham iguais sentimentos, à vista do que em silêncio logo escolta por toda cidade, e guarnecidas as embocaduras (SIQUEIRA, 2002: 90).

Segundo Siqueira (2002: 90), esta passagem, contada pela voz dos rusguentos, se configura no episódio da primeira noite do movimento:

Os rusguentos arrombaram casas comerciais, saqueando-as e matando os "bicudos", nome que designava todos aqueles que pertenciam à antiga elite comercial e latifundiária, composta por muitos portugueses adotivos, estrangeiros e até mesmo brasileiros.

No momento em que eclodiu a Rusga, Poupino Caldas, então responsável pelos destinos político-administrativos da província mato-grossense , deixando o Palácio do Governo, saiu às ruas acompanhado do bispo D. José Antônio dos Reis, clamando aos revoltosos que parassem o movimento. Indignados com a atitude do governante, os rusguentos prosseguiram com as perseguições, acusando Poupino de traidor" (SIQUEIRA, 2002: 90).

Em um conjunto expressivo, o poeta Aquino Corrêa, com o esmero da linguagem na elaboração da matéria poética, numa mesclagem de história, literatura e religião, recria, no soneto A Rusga, esse momento da história do Mato Grosso.

Ao grave badalar do sino sobre a torre, Batendo a meia-noite, eis que o motim se agita:

Vibram clarins cortando a calada infinita, $\mathrm{E}$ há tropel de quem foge, e vascas de quem morre. 
O sangue português em púrpuras escorre, no vale em flor, por onde o Cuiabá dormita...

Trinta de maio! Noite atroz! Noite maldita!

Que eterno sobre ti o nosso pranto jorre!

Então foi que se viu (aparição arcanal)

Entre acesos brandões, a pé, de rua em rua,

O bispo Dom José passar, triste e silente.

Nas mãos ambas erguendo a cruz, onde, amplamente, Cristo os braços abria, exangue, à luz da lua, Aplacando o furor da tempestade humana.

A "Retirada de Laguna" é um outro soneto de Aquino Corrêa que reforça esta deriva ou passagem da história para a literatura. Através da elaboração da matéria poética, o poeta recria um episódio da história, cantando em versos o que Visconde de Taunay narrou em forma de romance histórico.

As hostilidades paraguaias fizeram não só interromper a navegação pelo rio Paraguai, como também uniram três países, Uruguai, Argentina e Brasil, através do Tratado da Tríplice Aliança, em uma frente de combate aos desmandos políticos do governo paraguaio Solano Lopes. Após a apreensão da Canhoneira Amambaí, da Marinha do Brasil, no rio Paraguai, e da invasão da então Província do Mato Grosso pelas forças do Exército Paraguaio, em dezembro de 1864, uma das primeiras reações brasileiras foi a de enviar um contingente militar terrestre para combater os invasores, em Mato Grosso. Em abril de 1865, uma coluna partiu do Rio de Janeiro, percorrendo mais de dois mil quilômetros por terra até alcançar Coxim, na Província do Mato Grosso, em dezembro desse mesmo ano.

Em janeiro de 1867, essa coluna decidiu invadir o território paraguaio, penetrando-o até Laguna, em abril. Distante das fronteiras brasileiras, sem alimento para o sustento da tropa, afetada pelo cólera, tifo, e pelo beribéri, a coluna do Exército Brasileiro foi forçada a se retirar das terras paraguaias, sob os constantes ataques da cavalaria paraguaia.

De um efetivo de cerca de três mil homens, retornaram às linhas brasileiras em Coxim, em junho de 1868, apenas 700 homens, alquebrados pela doença e pela fome. 
É exatamente este fragmento da história do Brasil que Aquino Corrêa transformou em poesia através do soneto "A Retirada de Laguna":

\author{
Fora de tão bela e heróica essa avançada! \\ Tantos louros trazíeis ao Brasil, \\ Quando que o céu e o fogo e a peste irada, \\ Tudo vos assaltou com fúria hostil! \\ Martirológio atroz! A terra inchada \\ Saciou-se em vosso sangue tão gentil! \\ Ah! Fostes mais heróis na retirada, \\ Do que batendo a fera em seu covil! \\ Qual outrora os Dez-Mil, vendo raiar, \\ Ao longe, o azul da imensidade equórea, \\ Romperam neste grito: o mar! O mar! \\ Assim vós, ao entrardes para a História, \\ Que então se vos abriu, de par em par, \\ Fostes cantando: a glória! A glória!
}

Damos privilégio a alguns aspectos que julgamos responderem às nossas formulações sobre a língua literária, numa perspectiva que pode revelar o posicionamento crítico do escritor, diante da língua.

Aproveitando-nos da afirmação de Neto (2001), de que algumas formas poéticas são singularíssimas em Aquino Corrêa, dentre as quais se destacam a anáfora e a ironia, que enquanto "chicoteiam, também acariciam, pela exímia beleza literária" (NETO, 2001:9), realçamos a ironia nos versos "Ah! Fostes mais heróis na retirada / Do que batendo a fera em seu covil!", do soneto "A Retirada de Laguna", em que o poeta ironiza a precariedade das tropas brasileiras no enfrentamento das tropas paraguaias, durante a Guerra da Tríplice Aliança, no episódio da Retina da Laguna.

Retomando os postulados teóricos de Balakian (1966) sobre as formas de ruptura, que nos possibilitam estabelecer a distinção entre o original ligado à origem e o original ligado ao novo, destacamos a sátira como uma quebra de convenção, uma forma poética utilizada por Aquino Corrêa como uma crítica social, muito mais inspirada "no clima social da época do que numa filosofia de revolta pessoal" (In: Nitrini, 2000: 142). 
Evidentemente, Neto (2001), em seu ensaio crítico, trata Aquino Corrêa, como o "orador", um "esplendente burilador da frase". Embora o ensaio crítico de Neto seja da oratória de Aquino Corrêa, o escritor não deixa de ressaltar determinados aspectos expressivos que se traduzem também, em formas poéticas próprias da linguagem literária:

No comum, quando enfrenta os grandes problemas sociais do século, o faz com um senso de proporção admirável. Não agrideapodera-se do fato e o envolve, destruindo-o como que por absorção, não como o ácido da ira que o desmantela e corrói, com escândalo, - mas com a espuma da sutileza poética que submete, como um canto adormecedor; mata, mas não tortura; convence, mais do que vence. Chegava mesmo a brandir a arma do gracejo para arrostar os erros temporais (NETO, 2001: 9).

João Antonio Neto, ao escrever sobre a erudição em Aquino Corrêa, não a traduz como preciosismo, delicadeza ou sutileza excessiva ao escrever. Para o crítico, ela se constitui como uma marca da sua instrução vasta e variada, adquirida sobretudo através da leitura, e expressa num tom que, embora carregado de cultura clássica, é extremamente parcimonioso nos lances de eruditismo precioso, preferindo a singeleza da justa medida ao barroquismo que tanto viciou e obscureceu a retórica do passado (NETO, 2001: 10).

Analisado sob a bandeira da crítica literária, o artigo Dom Aquino, o orador, de João Antonio Neto (2001), é o que mais se aproxima de uma crítica literária resultante dos estudos analíticos da linguagem poética de Aquino Corrêa.

Neto (2001: 11) avalia a linguagem poética de Aquino Corrêa assentada no vigor da sua linguagem quanto ao emprego das "figuras de construção", de "antíteses fulgurantes", das "perífrases buriladas de magníficos efeitos", das "anáforas", etc .

Para João Antonio Neto, Aquino Corrêa

possuía o mais genuíno dom da palavra - de saber dizer e principalmente, por que dizia.Neste porquê é que está uma das forças irresistíveis da eloqüência, todas as legítimas virtudes do seu pensamento e da sua mensagem. Jamais se lhe verá qualquer ato oratório em que apenas se sinta o adejo leve e melífluo das imagens - porque, sempre, e consistentemente, está em tudo quanto disse em público, a densidade de pensamento, de 
um sistema de idéias motrizes, refinadas e amadurecidas, e a segurança- quase diria fatalista- do seu papel de intérprete de uma força maior, emanada dos princípios da sua religião e do seu Deus"(NETO, 2001: 11)

Segundo Neto (Ibidem, p.2-13), as figuras de pensamento como a metáfora e a metonímia são amplamente utilizadas por Aquino Corrêa para acentuar o caráter poético da sua linguagem, seja em verso, seja em prosa, como: "a espada como a cruz, há de ter os seus sacrários. Ambos são símbolos da força indispensável ao homem, uma força material, outra força espiritual e imponderável, mas uma e outra a serviço unicamente da ordem".

Aquino Corrêa encarna uma figura polêmica neste início de século XX. Para o crítico literário João Antônio Neto (2001), o caráter formal das obras de Aquino Corrêa preserva traços imprescindíveis para se estabelecer a distinção do escritor que, antes de qualquer juízo crítico, deixa ver sua face de humanista e erudito, homem informado de todos os conhecimentos respectivos, e plenamente integrado às realidades do seu tempo; como religioso, o Arcebispo de Cuiabá, versou, na pregação, todos os temas polêmicos da sua época, como o culto cívico à Pátria, os problemas da liberdade de pensamento, questões sobre a razão e a fé, arte e moral, literatura brasileira e universal, usos e costumes sociais, pedagogia e regionalismo, história da catequese, história do Brasil e de Mato Grosso, interesse da família e da juventude.

Segundo o crítico, Aquino Corrêa passou por todos estes tópicos, cujos enunciados definem sua importância, examinou assuntos significativos, oportunos e instantes, fez e disse tudo sobre essas coisas e tantas outras, mas tendo sempre presente, de forma intangível e reiterada, como numa santíssima obsessão, "o primado da Igreja e a absoluta necessidade de Deus" (NETO, 2001: 14).

Parafraseando Neto (2001: 18), reiteramos o caráter significativo de Aquino Corrêa no cenário das letras em Mato Grosso, realçando a forma como os grandes homens se fazem na História.

Estes homens mergulham na história político-social do seu povo, através da participação nas angústias e glórias dos seus dias, destacando-se como "as criaturas que transbordam das ribas morais, e se derramam a fertilizar as terras ásperas e 
tórridas comunicando-Ihes o húmus de sua vitalidade e as excelências das suas florações":

Pois, há criaturas que são meramente homens; outras há que são o homem. Homem é o indivíduo, como unidade biológica, confundível com outros da sua espécie. Mas o HOMEM é o protótipo, o paradigma: aquilo de primeira qualidade, que gostaríamos de ser ou que, generosamente, estimaríamos que todos fossem. Algo assim como o tipo padrão, o modelo acabado e refinado do ente e do agente. Há homens que acontecem, como acontece qualquer fenômeno físico-químico- como a combustão duma vela ou o trânsito de uma nuvem- mas, há homens que são um acontecimento humano.Há homens eventuais, como borboletas verdes e rosas negras...

Mas há também homens inevitáveis - cuja vida é um ato constante de presença completa, significação permanente e fulguração indispensável.

Há homens que chegam e passam-mas, há outros, são intransitivos e se transformam em vertentes do tempo:são os homens plurais, que viram substantivos comuns, e aparecem transfigurados, às vezes, em ruas e praças, estradas e rios, confundidos com a poeira de todas as datas, como o perene e 0 eterno.

Há homens que não morrem, não podem morrer- encantam- se, como diria Guimarães Rosa- e Dom Aquino passou por aqui, e aqui ficou encantado e encantando" (NETO, 2001, 18-19).

Marcamos, através da figura de Aquino Corrêa, este momento de transição de consciência estética (1902-1922), em que a beleza da forma e a beleza do conteúdo resultam muito mais como formas de interação no complexo processo de simbiose de elaboração do objeto estético, preservando - se como sustentáculo para a teoria da crítica literária em Mato Grosso.

Perseguindo a hipótese de que, a partir de Aquino Corrêa, encontramos os parâmetros crítico-teóricos norteadores dos estudos da literatura em Mato Grosso, registramos no ensaio crítico de João Antônio Neto, O Modernismo em Mato Grosso: reencontro com Silva Freire (2001), três momentos, resultantes de olhares críticos sobre o modo particular com que cada escritor elabora a matéria ou a forma dos seus poemas, vindo a significar inovações na poesia produzida em Mato Grosso.

No primeiro momento, temos a poesia de cunho social, praticada a partir de Lobivar de Matos, o qual é, para João Antonio Neto, "a primeira voz definitiva do 
Modernismo entre nós". Para o crítico, "antes de Lobivar, ninguém na poesia matogrossense havia trilhado esses caminhos", esta referência nos remete à poesia cuja matéria poética versa em torno da crítica social (NETO, 2001: 24).

Neste momento, escritores como Gervásio Leite, João Batista Martins de Melo e Rubens de Mendonça, filiados à idéia de modernidade proclamada pela revista Pindorama, propõem um movimento poético renovador que tem, na matéria ou na temática social, o cunho revolucionário, característico do ano de 1939, da poesia modernista.

No segundo momento, registra-se, o que definimos como uma retomada da elaboração da forma poética, traduzida como uma atitude transgressora, marcada pela liberdade de expressão do poeta, utilizando-se das formas que the convierem à expressão da matéria. Segundo Neto (2001), este momento é uma resposta da literatura que, após a Segunda Guerra Mundial, por volta de 1949, em Mato Grosso, "ganha dimensões e vivacidade" (NETO, 2001: 26-27).

Conforme a crítica de Neto (2001), o surgimento da revista Ganga não conota nenhuma pregação revolucionária, nem insinua nenhuma inovação de "culto", porém, parece querer dar forma ao mundo fragmentado "que saíra da guerra e ainda não criara suficientes razões para se crer salvo do naufrágio que o ameaçara" (NETO, 2001: 26-27).

O certo é que foi neste clima e através da revista Ganga, que partiram algumas vozes que significaram 0 coroamento da mais alta poesia mato-grossense contemporânea, revelada através da transgressão da forma. Citemos Wladimir Dias Pino, Silva Freire e Amália Verlangieri que "apontavam com ângulos totalmente ignorados dos nossos ouvidos centenários" (NETO, 2001: 26-27).

Através das vozes destes escritores, a temática social ganhou novos contornos e passou a ser o mote de poemas que transgrediam através da forma.

Convictos de que a poesia se concretiza no modo particular com que o poeta se arranja na elaboração da linguagem da forma e da matéria poéticas, percebemos que através de Silva Freire, os arranjos provocaram inovações processadas através da elaboração das formas de organização do poema. Neste sentido, o conjunto de versos, tradicionalmente designado de estrofe, receberam a denominação de "blocos 
poemáticos", devido às possibilidades de individualização de aspectos da matéria do poema, fragmentada em unidades menores de expressão.

No artefato dos "blocos poemáticos", os versos do poema ganharam autonomia, atingiram maioridade, as palavras ganharam a forma de "palavra-tema", que propiciavam múltiplas direções de leitura (RAML/Jubileu de Diamante, 1996:315) ${ }^{48}$.

Talvez seja esta a inovação mais significativa da forma poética no Modernismo, porque este modo de elaboração da linguagem poética provocou uma fragmentação do poema em unidades significativas menores, dando autonomia de significação a cada verso do poema.

Em Silva Freire, verifica-se a retomada do conceito aquineano da manifestação da poesia, centrada na beleza da forma e na beleza da matéria, através do caráter de mobilidade adquirido pela palavra que ganha expressividade em várias direções, tanto na horizontal, como na vertical e na diagonal constituindo-se como unidades móveis de expressão.

Os elementos sonoros dos versos, que agora, mais do que nunca, acentuam o caráter de livres, exprimindo com maior visibilidade a liberdade de expressão do poeta, são expressos através de palavras que se quebram e requebram em um ritmo, em uma movimentação de sílabas poéticas em várias direções, como é o caso de - "o oleiro", de Silva Freire, do qual transcrevemos apenas dois blocos poemáticos:

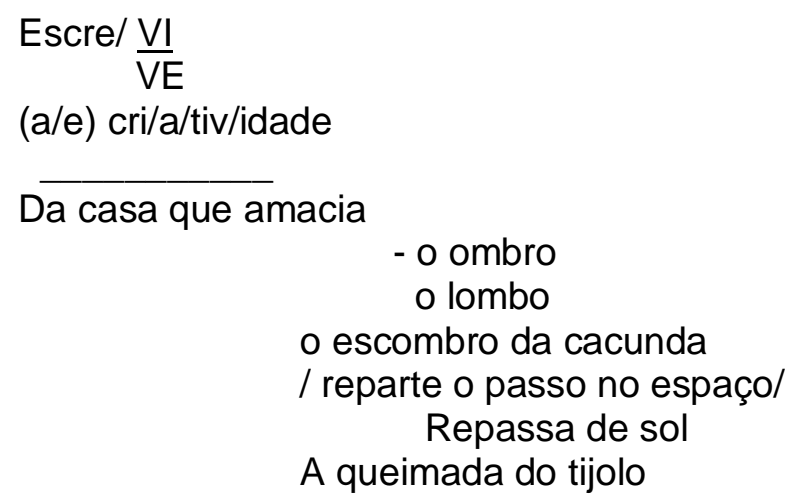

48 RAML- trata-se da Revista Mato-Grossense de Letras, publicada em 1996, nas comemorações alusivas ao Jubileu de Diamante da Academia Mato-Grossense de Letras. 
Simultaneamente, surgem o "Intensivismo", o "Parvinismo" e o "Concretismo", propondo novas "formas" literárias, que traduzem símbolos representativos da liberdade de expressão, como marcas características do Modernismo em Mato Grosso.

Sob vários ângulos, percebe-se a multiplicidade de formas do artista elaborar a linguagem poética e expressar a matéria dos seus poemas.

Em um tempo histórico, que nos parece muito pouco distanciado do tempo histórico de Aquino Corrêa, Vladimir Dias Pino aparece como o escritor que mais se aproxima desta tendência crítica, assentada na transgressão provocada pela busca da "beleza da forma e da matéria poética" propondo através do movimento que ele denominou de "intensivismo", uma nova escola literária.

Nesta nova escola literária, que à moda do Parnasianismo, privilegia a forma poética, retoma-se o critério originário em Aquino Corrêa de "esmero da linguagem poética". Nela, a palavra assume o estatuto de forma, figurando como uma forma de aparência da matéria poética - "aparência que não esgota a realidade"; e a forma do poema se configura como o espaço de lavor do poeta. Assim, à moda do poeta parnasiano, o intensivista cria, esculpe uma forma, que "o comum dos mortais não vê, mas ele vê" (NETO,2001:31).

O Parvinismo, segundo João Antonio Neto (NETO, 2001: 31), seria toda a manifestação do original sem a contaminação das formas estereotipadas dos condicionamentos artificiais; seria a natureza in natura, intocada. Seria um "grande achado" suscitar novas formas de beleza e encantamento espiritual, fazendo com que se realizassem expressões puras da realidade, antes desconhecidas.

Ora, interessados em acentuar a nossa atração pela conceituação, detivemo-nos mais demoradamente em Wladimir Dias-Pino, em sua obra Processo: linguagem e comunicação $(1978)^{49}$, por considerarmos que este relativiza os conceitos já tradicionais nos estudos da teoria e da crítica literária, introduzindo outros semelhantes, abrindo assim a possibilidade de "uma ordenação e interesse didático, no sentido de que a ciência busca uma linha única de desenvolvimento".

\footnotetext{
${ }^{49}$ DIAS-PINO, Wladimir. Processo: linguagem e comunicação. 3. ed. Rio de Janeiro - Petrópolis: Editora Vozes, 1973.
} 
Evitando dogmatismo, Dias-Pino (1978) pretende, com a sua obra, desenvolver uma "crítica visual" mediante a organização do poema. Sob esta perspectiva, o poema é "apenas veículo transitório da função didática", a linguagem poética é uma opção tática, o "processo" é a manipulação mais o desencadeamento de invenções sistemáticas do contra-estilo, e "o movimento ou a participação criativa é que leva a estrutura (matriz) à condição de processo. O processo do poeta é individualista, e o que interessa coletivamente é o processo do poema".

Está evidente que, no Concretismo, as palavras mudaram, mas os conceitos permanecem relativizados, alargando-se a concepção de poesia como uma forma concreta, inclusive visual, concretizada na forma do poema, que, além da leitura inferencial dos versos, propõe a leitura da poesia, na forma organizacional do poema.

Para atender aos nossos objetivos em relação à crítica literária, do Concretismo, interessa-nos a operação, a transgressão que se dá pela forma como o poeta concretiza a poesia, transformando-a em objeto concreto, no poema, através de um processo esmerado de elaboração da linguagem, para o qual entram em concorrência matérias simbólicas de natureza tanto concreta quanto abstrata.

As matérias de natureza concreta como o papel, o espaço branco ou colorido do papel, as palavras, seguindo ou não em estrutura convencional, escritas no verso, no inverso ou no reverso, a disposição destas na página (em cima, embaixo, à esquerda, à direita, na diagonal, na horizontal ou na vertical, próximas umas às outras ou distanciadas); bem como a matéria de natureza abstrata, ou o tema, dependente de uma relação de interpretação, estritamente subordinada à análise das unidades sonoras do poema, são elementos formais que concorrem para a avaliação crítica da poesia do movimento concretista.

A crítica literária, portanto, subordina-se a relações de pertinência da disposição da palavra na página, em relação funcional com o espaço branco ou colorido do papel, bem como, o processo de cognição de um léxico, a expressividade de certas unidades cognitivas que "em composições breves e densas, baseadas não raro, no jogo de palavras, nas alterações de sentido ligadas às alterações sonoras" (NETO,2001: 32), representam, no Concretismo, formas atualizadas de elaboração da matéria poética. 
No poema-processo, a palavra deixa de ser elemento criativo de importância, como ainda o fora na poesia concreta, e passa a dominar a geometria, a disposição de elementos que atinjam a sensibilidade, mais pela forma do que pela essência da matéria que ela traduz (NETO, 2001: 31).

Concluímos que a partir dos postulados teóricos constantes, no movimento de criação do poema-processo, a beleza da forma e da matéria se traduz numa nova "fórmula" de "ver para sentir" (NETO, 2001: 32).

Ao que tudo indica, perseguindo o posicionamento de Neto (2001: 32), com o surgimento do "poema-processo", a evolução dos estudos literários suscita uma nova modalidade de análise crítica do poema, que se instala no sistema literário num entrecruzamento teórico: o poema-processo anda pelas fronteiras onde a língua desaparece e surge a linguagem universal; a beleza não precisa ser interpretada, mas apenas imposta, pela coisa capaz de representá-la, então não há necessidade de instrumento outro de comunicação, se a palavra não tem sentido, deve ser abandonada. Claro, a palavra restrita à condição de signo lingüístico, perde a sua essência simbólica, resultada da motivação do poeta.

Tradicionalmente, havia um sentimento estético, com o surgimento do poema processo, há muito mais percepção estética. Passamos da arte psicológica, centrada no espírito, para a "estética ambiental" (NETO, 2001: 33), isto é, uma arte que se assenta no todo que representa o poema.

Mediante o posicionamento crítico de Neto (2001: 33), a arte convencional é imóvel, pautada pelo limite, pelo estereótipo e pelo clichê, a reiteração e a insistência em um modelo acomodam-na dentro de uma fronteira artificial, contrapondo-se ao que deve ser a principal característica da arte, ou seja, a criatividade e a liberdade de expressão.

Pressupõe-se que na estética moderna, haja uma mobilidade das fronteiras, e a crítica literária busca a "inumerabilidade" das coisas, das vozes e de nós mesmos, "a existência de perspectivas ilimitadas, uma perpétua anunciação" (NETO, 2001: 34).

Assim, a poesia, neste agora, "não se pode conferir porque não há uma matriz, um modelo, desde que flui, desde que a realidade é feita de momentos sucessivos, ordenados ou não, seqüentes ou não", a poesia existe na arte moderna, sem ter, 
verdadeiramente, um fim, simplesmente porque a finalidade está fincada em nenhum aspecto da realidade. O que chamamos finalidade é uma espécie de desculpa para salvar a nossa complexidade diante dos crescentes estímulos, ou, segundo, o próprio Neto, diante da "inumerabilidade" dos motivos para a criação simbólica (NETO, 2001: 35).

Esta complexidade coletiva, a que alude Neto, acontece graças à ausência absoluta de critérios que possam representar esta complexidade, no âmbito de uma crítica literária fundamentada, que foge dos critérios meramente impressionistas.

A beleza da forma e a beleza do conteúdo e a duplicidade do belo ecoam distante como a retomada de um parâmetro único, capaz de nortear e dar rumo à crítica literária, nesta primeira metade do século XX, em Mato Grosso.

João Antonio Neto (2001) vai além de seus posicionamentos críticos para pensar a poesia praticada em Mato Grosso. A partir das obras de Manoel de Barros, focalizando a questão da "reinvenção da linguagem" como um novo momento da crítica literária, ressalta a necessidade de a crítica retomar o domínio da palavra "que funciona, reinterpretando as coisas e os sentimentos, através de uma eclosão plástica, abundante e sinfônica" (NETO, 2001: 36).

A crítica literária retoma a questão da língua literária como instrumento com que o poeta se sustenta, e cresce à proporção que os estímulos temáticos se multiplicam, assim:

Todas as categorias gramaticais, toda a Morfologia, toda a Sintaxe adquirem nova dimensão, estabelecendo-se entre as estruturas da língua um intercâmbio "insólito", ditado não pelas normas rígidas já fixadas, mas pela necessidade de traduzir a realidade através de uma nova semântica (NETO, 2001: 37).

Procurando privilegiar os aspectos críticos, que mais significativamente explicitem uma linguagem literária subordinada a certos comportamentos normativos existentes no sistema literário, buscamos os posicionamentos críticos do Padre Pedro Cometti $^{50}$ (1994:,514 - 518), que em sua obra Dom Aquino Corrêa, Arcebispo de

\footnotetext{
${ }^{50}$ Autor da obra Dom Aquino Corrêa:Arcebispo de Cuiabá. Vida e obra.Editada pelo Centro Gráfico do Senado Federal, em 1994.
} 
Cuiabá: vida e obra, distingue o poeta e faz o traçado crítico dos postulados de Aquino Corrêa, através da voz do próprio poeta e de outras vozes, preocupadas, assim como Aquino Corrêa, em encontrar o lugar e a função que o poeta desempenha na crítica consciente da produção literária.

Segundo Cometti (1994), para Aquino Corrêa existe uma vocação literária sempre subordinada a princípios lingüísticos, à vocação literária, em particular, e reside, a princípio, na língua materna, reveladora, em toda a magia de sua beleza, na opulência do seu vocabulário, na suavidade dos seus ritmos, na formosura da sua frase, na majestade latina dos seus períodos (COMETTI, 1994: 514).

Os postulados críticos de Aquino Corrêa, observados por Cometti (1994), em relação à língua, remetem-nos à língua literária, assentando-se nas fontes que alimentam uma consciência de que a literatura não se faz senão por influências que impulsionam e explicam a gênese do conhecimento.

Bendigo hoje, as demoradas leituras e vigílias estudiosas, em que longe da vida ao léu, tão própria daquela idade, foram-se-me horas esquecidas no ler e reler o escol dos nossos clássicos, ou mesmo no manusear de um simples léxico da língua, à cata de expressões novas ou acepções seletas e elegantes (COMETTI, 1994: 514).

Para Cometti (1994: 515), o escritor e o crítico literário Aquino Corrêa tem seu estilo e a sua vocação literária assentados em "dois ideais que inspiram a todo e qualquer homem de letras: um que Ihes é comum a todos eles, e outro que os especifica e distingue; um que mais concerne à forma, e outro à matéria das criações" (COMETTI, 1994: 514).

O que se depreende da afirmação de Cometti (1994), é que existe um sistema literário, e no interior desde sistema, o que é comum a todos os poetas é a língua materna, a perfeição do vernáculo, "o idioma venerável dos gênios da raça, sorrindonos no impecável de sua correção, no extremo da sua pureza e no mais aprimorado da sua elegância" (COMETTI, 1994: 515). Quanto ao ideal que, no interior do sistema, "os especifica e distingue", traduz o modo particular de cada poeta elaborar e dar forma à matéria. 
Neste sentido, Aquino Corrêa traduz-se, para alguns críticos, como poeta, inserido num sistema literário, moldado conforme os valores clássicos, comportando um determinado estilo artístico individual com uma conotação valorativa redutora, representando um tempo passado em que o poeta era aquele que "pela vernaculidade da sua locução, pode ser considerado como mestre da pureza do idioma e, portanto, como um modelo a ser seguido pelos que se consagram à arte de escrever" (AGUIAR e SILVA, 2000: 506).

Segundo Aguiar e Silva (2000), esta concepção de classicismo se alicerça, predominantemente, em motivos gramaticais, e não em fatores, propriamente literários ou estilísticos, tratando-se, portanto, de uma atitude eminentemente estéril para a literatura, visto que reduz a competência do poeta às formas de arranjo dos elementos lingüísticos do poema, esvaziando-o de elementos literários.

Afiliados ao juízo crítico de Aguiar e Silva (2000:506-507), segundo o qual, nos estudos literários será impossível desvincular os vocábulos "clássico" e "classicismo" de tudo que diga respeito à literatura greco-romana, dada a força da tradição e dos hábitos lingüísticos presentes nas literaturas de língua portuguesa, propositalmente, damos preferência a uma concepção para "classicismo" que o comporta como uma constante do espírito humano.

A concepção de "classicismo" como uma constante do espírito humano, e, por conseguinte, uma constante também da literatura, centrada na constância da ordem, do equilíbrio e da harmonia, é o que nos interessa, quando tratamos de apresentar Aquino Corrêa como o escritor, cujo discurso prevê um sentido estético-literário coerente ao desenvolvimento de uma crítica literária, teoricamente rigorosa, sistemática e bem fundamentada, como condição primordial para se conceber uma produção literária que realmente valha a pena. 


\section{CAPÍTULO 5}

\section{Fronteiras: a língua literária e os papéis da tradição e da modernidade}

O único fator que une a modernidade é a diversidade, filha do individualismo e da liberdade, grandes conquistas da humanidade (Joaquim Matos, 2003). 
Tivemos ocasião de referir-nos anteriormente a dois aspectos fundamentais do nosso estudo: um, é deixar clara a distinção entre literatura como arte e estudos literários como conhecimento especializado (WELLEK \& WARREN, 2003: 3); outro, é fazer um percurso comparativo, usando a comparação como um método, um procedimento mental que favorece tanto a generalização como a diferenciação (...) um ato lógico-formal de pensar o diferencial, de forma processualmente indutiva, "paralelo a uma atitude totalizadora (dedutiva)" (CARVALHAL, 1998: 6).

Estes dois aspectos, intimamente associados, dão-nos a base necessária para estabelecer a distinção entre a linguagem literária e a linguagem científica, aspectos fundamental para realizar o estudo do "belo sob o prisma literário, único que, nesta hora, aqui nos ocupa e interessa" (CORRÊA, 1985 b: 18).

No rastro teórico de Carvalhal (1998: 6), reforçamos a utilização da comparação como "procedimento mental que favorece a generalização ou a diferenciação", assegurando-nos que "comparar é um procedimento que faz parte da estrutura de pensamento do homem e da organização da cultura".

Valemo-nos da comparação, também, para explicitar um comportamento necessariamente analítico da crítica literária, que, ao analisar uma obra, deve estabelecer confrontos com outras obras de outros autores, para fundamentar os juízos de valor, que resultam em respostas positivas quanto ao funcionamento de tal obra no interior de um determinado sistema literário.

Este comportamento analítico leva a se constatar uma dependência epistemológica da teoria da literatura e da teoria da crítica literária, assentadas no modo simultaneamente deliberado e sistemático de uso da linguagem literária.

Em relação ao objeto do nosso estudo, a distinção entre linguagem literária e linguagem científica nos interessa até o ponto em que dimensiona o gesto criativo subordinado a determinadas convenções lingüísticas, nos termos propostos por Wellek \& Warren (2003):

Quaisquer que sejam os modos mistos evidentes em um exame de obras de arte literárias concretas, as distinções entre o uso literário e o científico parecem claras: a linguagem literária está muito mais profundamente envolvida na estrutura histórica da linguagem; ela enfatiza a consciência do próprio signo; ela tem o 
seu lado expressivo e pragmático, que a linguagem científica sempre desejará, tanto quanto possível, minimizar (WELLEK \&WARREN, 2003: 16).

Atingindo o ponto que consideramos fulcral dos nossos estudos, confrontamonos com a questão polêmica entre a tradição e a modernidade. Como não é nosso interesse adentrar nos aspectos dialógicos dessa polêmica, limitamo-nos a utilizar estes termos até que seus conceitos respondam por "momentos", que contemplam nossos estudos sobre a história da cultura literária do Mato Grosso.

Neste sentido, a epígrafe do capítulo sintetiza o juízo crítico de Joaquim Matos ${ }^{51}$ sobre a modernidade, e interessa-nos, em particular, por nos remeter ao paradoxo da moda na modernidade: o individualismo e a liberdade, duas grandes conquistas da humanidade.

Joaquim Matos, em seu ensaio crítico "Eles nunca saberão"52, acentua um caráter de atualização constante da arte. Numa espécie de paráfrase, o crítico nos diz que

Nada há de novo debaixo do solo, diria Salomão, mas a arte é uma fonte inesgotável, em que tudo se repete, sem se repetir, mercê de uma montagem de peças em novas construções, dos novos ângulos que se descobrem na câmara, nos tons de luz que surgem, na renovação da função da palavra, o que nos toca novamente pelo tratamento criativo que se abre até ao infinito. Criar, hoje, é isso, uma reciclagem que mantém viva e actual a função da obra, arrastando o leitor consigo nos novos ingredientes introduzidos e trabalhados (MATOS, 2003).

Segundo o escritor português, toda a atividade humana, na modernidade, passa pelo individualismo e pela liberdade, com as suas conseqüências mais sublinhes, mais nefastas e destruidoras, que em ritmos progressivos, vão suscitando mudanças e

\footnotetext{
${ }^{51}$ MATOS, Joaquim. "Um espaço na modernidade", ensaio publicado na revista eletrônica Letras \& Letras/wwwalfarrabios.di.uminho.pt/vercial/letras/ensaio51. A produção poética de Joaquim Matos tem os seguintes títulos: Ossadas Vivas (1970), Ondas Curtas e Longas (1971), Colhendo o Vento nos Frutos (1984), Palavra Indeferida (1989), Uma Noite com Maat (1996), A Idade do Tempo (1997), Gare Marítima (1998), Kaaba (1999), O Corpo da Memória (2000) e O que Apetece Dizer-Te (2004). Publicou o livro de ensaios Mário Cláudio: Ficção e Ideário (Porto, Caixotim, 2004).

52 Ensaio crítico do conto homônimo, de João Afonso Machado, publicado na revista de literatura Letras do Caixotim, no Porto, em Portugal, em junho de 2003. Já o ensaio de Joaquim Matos é datado de 20 de agosto de 2003.
} 
atualizações, que, ao contrário das civilizações passadas, na modernidade não há norma que se estabilize numa página, num tempo limitado.

$\mathrm{Na}$ modernidade, há normas, de começo, ainda que consideradas rígidas, sempre abertas a aplicações diferenciadas, mas rapidamente são ultrapassadas por outras que Ihes seguem, até se chegar à atualidade em que cada um procura a sua própria norma, não só para o seu estilo como para a sua estética, em particular. Este movimento é seqüencial e acumulativo, ocorrendo um processo que atinge uma dimensão coletiva e histórica.

Apropriamo-nos da crítica de Matos (2004), segundo o qual, em todas as artes, inclusive, a arte literária, que é a que nos interessa, todos os ismos, em especial, os que se seguiram ao Romantismo, é um espelho desses processos de atualização, que traduzem uma preocupação tradicional, porém sempre presente nos estudos críticos da literatura: a preocupação de pôr carimbo às coisas, a necessidade de agarrar um fluido, que sustenta o corpo da modernidade.

Neste direcionamento dado aos nossos estudos, usamos a significação de "modernidade", proposta por Frederic Jameson, em sua obra Modernidade singular: ensaio sobre a ontologia do presente, entendendo que "modernidade 'significa' sempre estabelecer e postular uma data e um começo" (JAMESON, 2005: 43).

\subsection{Aquino Corrêa: a busca do espaço na Modernidade}

Se anteriormente nos orientamos pelo 'significado' de modernidade, proposto por Jameson (2005), para estabelecer, a partir de Aquino Corrêa, um começo para os estudos críticos da poesia produzida em Mato Grosso, assentados na elaboração da forma e da matéria poética, prosseguimos com os postulados críticos de Jameson, porém, voltados para a objetividade da conceituação.

Nesta linha, a modernidade é conceituada como "uma nova situação histórica"; a modernização como "o processo pelo qual se chega lá", a essa nova situação histórica; e o modernismo como "uma relação tanto com aquela situação histórica denominada 'modernidade' quanto com o processo através do qual se chega à modernidade. Esta 
relação que pode ser "estética e filosófico-ideológica, pode ser tanto positiva como negativa" (JAMESON, 2005: 117) ${ }^{53}$.

Hipoteticamente, a modernidade, a modernização e o modernismo se constituem através de um processo tridimensionado na correlação entre a existência de um conjunto de obras, que configura um sistema literário; um conjunto de "atores sociais", escritores e estudiosos da literatura, que configura a literatura, enquanto "arte criativa" e os estudos literários, enquanto "conhecimento", ambos, intimamente relacionados em um movimento constante de atualizações.

Ora, estas atualizações se traduzem através de estudos analíticos que possibilitam perceber criticamente, através do texto literário, o detalhe, o "pormenor textual", que individualiza o escritor ou a obra, no interior de um sistema.

$\mathrm{Na}$ perspectiva em que esta pesquisa se desenvolve, trazemos, para uma atualidade dos estudos da poesia produzida em Mato Grosso, os postulados críticos de Aquino Corrêa, sobre a forma e a matéria poéticas, postos a lume em 1917 e 1921. Fazemos um percurso investigativo que procura abstrair, dos estudos críticos realizados, o modo particular com que o poeta elabora estas duas "entidades" no interior de sua obra, de maneira que "este modo particular" se converta em um tipo de transgressividade ou ruptura, criando uma nova situação histórica no interior do sistema.

Assim, priorizando, no processo investigativo, os aspectos que podem ser vistos como inovações relacionadas à forma e à matéria poéticas, consideramos entender, no Brasil, o Modernismo a partir das Vanguardas Européias e da Semana de Arte Moderna de 1922.

Estes são dois momentos em que a forma e a matéria literárias foram o fulcro no palco da modernidade, ou de uma nova situação histórica da literatura brasileira.

Em Mato Grosso, entendemos esta "modernidade" a partir de Aquino Corrêa, como sendo o escritor que mais de perto pode configurar, crítica e teoricamente, o princípio de uma nova situação histórica da poesia no Mato Grosso, situada na fronteira onde se inicia a modernização, prevendo formas de elaboração particularizadas da

53 JAMESON, Fredric, (1934-), Modernidade Singular. Trad. Roberto de Franco Valente. Rio de Janeiro: Civilização Brasileira, 2005. 
matéria e da forma, ou seja, postula a modernização ou "o processo pelo qual se chega a essa nova situação histórica", o processo que traduz sistematicamente esta travessia entre o tradicional já assentado e a perspectiva do novo.

No muito que se escreveu sobre Francisco Tomás de Aquino Corrêa, é notória a participação do escritor em ações que configuram o desenvolvimento cultural do Estado. Citemos ações coletivas como a fundação do Instituto Histórico e Geográfico do Mato Grosso (1919), a fundação do Centro Mato-Grossense de Letras (1921) e a transformação do Centro em Academia Mato-Grossense de Letras, em 1932. O envolvimento do escritor com a cultura do seu Estado é notório nas três áreas do percurso do homem: na religião, na política e na literatura, especificamente, na oratória. Quer do ponto de vista literário, quer do religioso ou do político, Aquino Correa é a expressão mais próxima do devir histórico da sua época, no panorama cultural matogrossense.

O religioso, o político, o escritor, e as suas ações em prol da cultura, além das obras testemunhadas e traduzidas por inúmeras vozes, constituem um todo existencial, em que se vêem refletidas as preocupações críticas do escritor em face de uma sociedade cultural que precisava ganhar o seu espaço.

Aquino Corrêa não pode ser estudado por parcelas, se estas perderem de vista a totalidade dos posicionamentos crítico-teóricos do escritor, expressa através da sua obra poética e dos seus discursos, que é o que mais de perto nos interessa para fazer a sua inserção na história crítica da cultura mato-grossense.

Entendendo-se por totalidade do escritor, a sua obra poética, os seus discursos e as suas cartas pastorais, estabelecemos uma via, através da qual se pode entender a glória de Aquino Corrêa, e atribuir-Ihe positivamente o lugar de precursor da crítica literária da poesia produzida em Mato Grosso. Só por esta via se poderá procurar o seu lugar na modernidade, e, conseqüentemente, iniciar-se uma corrente de estudos e pesquisas sobre a história da teoria e da crítica da literatura mato-grossense, procurando encontrar os traços precursores destes estudos.

A começar pelas obras poéticas de Aquino Corrêa: Odes, Terra Natal e Nova et Vetera, diremos que elas traduzem três momentos da sua poesia: Odes, publicado pela primeira vez em 1917, traduz a infância do percurso de formação do poeta, refletida nas 
poesias escritas entre os dezesseis e dezenove anos de idade do escritor. Seus poemas traduzem os primeiros passos do poeta, além das poesias originais, e trazem traduções de versos latinos, italianos, espanhóis e ingleses, além de outros versos escritos em língua latina.

Essa poesia do cristianismo que, tão livre, palpita por todos os ideais puros, é que tentei reproduzir nestes humílimos cantos.Escrevi-os, pedindo a Deus fossem tais que pudesse repeti-los sem remorso à beira do túmulo, não como um eco nostálgico do mundo, mas, sim, como um prelúdio e anseio de canções eternas.Dei-lhes a denominação geral de Odes, tomando esta palavra na sua significação mais ampla e quase etimológica.A vós, pois, ó meus jovens patrícios, esta braçada cariciosa de versos, escritos com alma de moço, e, quase sempre ao contato eletrizante dos vossos sadios entusiasmos (CORRÊA, 1985 a: 44).

Em Terra Natal, publicado pela primeira vez em 1919, revela-se a maturidade do escritor preocupado com "o estudo da beleza em toda sua irradiação moral e artística", consciente de que "as letras não são outras que as belas letras, isto é, aquelas que mais de perto entendem as manifestações estéticas do belo", e que põe em relevo o caráter distintivo fundamental daqueles que se dedicam às letras, ou seja, os poetas: "dedicar-se ao culto beletrístico da matéria e da forma" poéticas (CORRÊA, 1985 b: 1617).

Em Nova et Vetera, publicado pela primeira vez em 1947, o escritor reitera o caráter científico e literário da linguagem da poesia, na esfera do que propõe o juízo crítico de Matos (2006), anteriormente citado, "até se chegar à atualidade em que cada um procura a sua norma, não só o seu estilo como a sua estética, em particular, a arte literária atinge uma dimensão coletiva e histórica".

Para Aquino Corrêa, os poemas em língua latina, que compõem parte do volume de Nova et Vetera, os quais o poeta julgou necessário revisá-los para que fossem reeditados, podem ser significativos, à medida que representam uma abertura à pesquisa literária "tanto mais que não será desprovido de interesse para estudiosos da poética latina, um cotejo entre a forma atual e a primitiva" (CORRÊA, 1985 c: 9-10).

Percebendo a importância de realçar a responsabilidade solitária do poeta diante do desafio da escrita poética, reescrevemos o soneto "Arte Poética", de Aquino Corrêa, 
que, muito a propósito, resume o pensamento do escritor em relação à procura de uma norma, de uma estética e de um estilo particular que transportam o poeta para a atualidade:

Se queres, poeta, que tua alma cante, Rumo ao céu, como a alada cotovia, Dá-lhe as asas da prece ardente e pia, Ao sol da fé, da tua fé radiante.

Estuda, estuda a fundo, noite e dia, O belo idioma límpido e cantante Para engastar a rima diamante, No ouro velho da clássica harmonia

Deixa depois teu estro voar, sem tolas Preocupações de mestres, nem escolas:

Fala-te o próprio Deus, no amplo universo!

Vai assim ao ideal que é a formosura Do espírito a brilhar, eterna e pura, Na áurea beleza plástica do verso! (CORRÊA, 1985 c: 103)

Odes, Terra Natal e Nova et Vetera funcionam como um símbolo de identidade do poeta Aquino Corrêa, na sua essência, compreendida entre o estilo particular do escritor e o gênero literário adotado por ele, e expresso através das seguintes formas literárias: odes, elegias, sonetos, epitalâmios, textos litúrgicos traduzidos em versos, em forma de hinos e canções; e o orador que se manifesta através da obra Discursos.

O Instituto Histórico e Geográfico do Mato Grosso e a Academia Mato-Grossense de Letras promoveram, em 1985, a editoração especial das obras de Aquino Corrêa, sob a coordenação de Corsíndio Monteiro da Silva ${ }^{54}$, considerado por Lenine de Campos Póvoas, então Presidente da Academia Mato-Grossense de Letras, e Luís Phillipe Pereira Leite, então Presidente do Instituto Histórico e Geográfico do Mato Grosso, como a pessoa adequada para executar "a tarefa ingente" de organizar e coordenar a publicação dessas obras, estabelecendo-Ihes os textos, atualizando-Ihes a ortografia, fazendo-Ihes as anotações de todo necessárias, principalmente, quanto a expressões de uso menos comum, reparando-lhes "possíveis cochilos de publicações anteriores", além de supervisionar os trabalhos de composição, apresentação e revisão

54 Corsíndio Monteiro da Silva é escritor mato-grossense, acadêmico ocupante da Cadeira 10 da Academia Mato-gossense de Letras. 
das obras do Arcebispo, junto ao Centro Gráfico do Senado federal (CORRÊA, 1985 a: 11).

Em Odes, Terra Natal e Nova et Vetera, tratamos de filtrar "o poeta", e, neste sentido, é José de Mesquita quem mais objetivamente nos revela o perfil do escritor, destacando, na personalidade do "grande Arcebispo cuiabano", a faceta das mais impressivas:

O gênio mágico da poesia, bem cedo revelado e mantido, galhardamente, até o fim.Poeta, mais que tudo, e acima de tudo, Dom Aquino o foi, sem dúvida, e, dos atributos que possui, enobrecedores e altíssimos, foi este o que constituiu o seu mais lidimo padrão de glória.É esse o seu mais belo e dignificante laurel, sendo o que mais eleva o homem ao plano quase divino (In: COMETTI, 1994: 526).

Através de diversos vieses, o historiador José de Mesquita ressalta o caráter do poeta, presente em Aquino Corrêa, e revelado através de todos os seus textos: "poeta, como orador, eis que os seus discursos são verdadeiros poemas em prosa"; através do jornalismo: "poeta, como jornalista, revelado através do periódico de matriz religiosa $A$ Cruz", veículo através do qual Aquino Corrêa registrou sua colaboração publicando diversas poesias cristãs; poeta também revelado em suas peças litúrgicas, como apóstolo do Bem, "enchendo a sua vida feita de beleza e despreendimento, dessa luz cálida e vivaz, da mais vera poesia, que clareia e aquece os corações" (In: COMETTI, 1994: 526).

Estas inúmeras formas de apresentação do poeta dão consistência ao discurso crítico de Aquino Corrêa em relação à procura de uma norma, de uma estética e de um estilo particular, que individualizam o poeta e o transportam para "o Infinito", ou para esta atualidade, em que buscamos, a partir de Aquino Corrêa, os princípios teóricos e críticos para pensar a poesia feita em Mato Grosso.

Ressaltamos, a necessidade de a partir de Aquino Corrêa fazer uma abordagem dos aspectos crítico-teóricos que julgamos indicar paradigmas para se pensar criticamente a poesia produzida em Mato Grosso. Neste sentido, é a obra Discursos (1985) que mais de perto nos interessa, visto que nela o escritor altera a relação do 
sujeito poético, enquanto criador de uma norma capaz de representar a atitude do poeta diante do desafio da escrita.

Os discursos de Aquino Corrêa sintetizam postulados teóricos que realçamos como condutores de uma visão de literatura, em que a obra e o homem constituem um todo existencial, onde o passado, o presente e o futuro sobrevivem juntos sob os efeitos da dialética, de um diálogo constante.

Ao fazermos o levantamento de todas as referências literárias que nos interessam, enquanto contatos que sustentam teoricamente os posicionamentos críticos de Aquino Corrêa, reafirmamos as raízes do poeta assentadas em um humanismo que o próprio escritor denomina como "meu humanismo":

Pondo à margem quaisquer outras modalidades do moderno humanismo, é meu intento esboçar-lhe apenas o aspecto literário, que mais diretamente diz respeito à Academia, humanismo, aliás, que não sei se corresponde bem à realidade, mas é como eu entendo e prezo, e estaria quase a chamar-Ihe, por isso, "meu humanismo (CORRÊA, 1985 c: 179) ${ }^{55}$.

Conforme dissemos, os posicionamentos críticos de Aquino Corrêa, ao mesmo tempo que representa o universo poético particular do escritor, funcionam como parâmetros ou instrumentos de normatização para se pensar criticamente as produções literárias mato-grossenses.

Aquino Corrêa distingue o "seu humanismo" em três momentos significativos e esclarecedores ao modo de se pensar a crítica literária.

Primeiro, considera como princípio essencial de todo e qualquer humanismo o culto da beleza da forma e a elegância do estilo. Segundo o crítico, o que mais encanta os humanistas, tanto nos prosadores como nos poetas clássicos da Antigüidade grecolatina, não eram tanto as idéias quanto a arte de exprimi-las com beleza. O verdadeiro humanista sempre foi um esteta da palavra. Assim, pois, para o crítico que prescindir da beleza literária na definição do humanismo, será desnaturá-lo (CORRÊA, Discursos, v. II, tomo II: 180).

${ }^{55}$ CORRÊA, Aquino. 1985, Discursos, v.II, tomo II: 173-184. Mensagem aos homens de Letras. Discurso proferido na Academia Brasileira de Letras. Rio de Janeiro, 14 de janeiro de 1937. 
Em segundo lugar, Aquino Corrêa destaca os meios a que se socorre o humanista para adquirir a "arte da palavra", que não é outra senão perseguir o que já dissera Horácio em sua Arte Poética - "Nem cultura sem talento, nem talento sem cultura". Aquino Corrêa reconhece que nem todos são os dotados dessa "rica veia", de talento e de cultura, portanto, somente os dotados dessa "rica veia", de que nos fala aí o poeta, podem aspirar à perfeição literária própria de um humanista, sobretudo, por acreditar na capacidade criativa do homem.

Neste sentido, o crítico recorre mais uma vez a Horácio, para ressaltar que aqueles que não são possuidores de uma "rica veia", não há outra recomendação geral a fazer, senão aquela do mesmo cantor da Arte Poética, que deixou escrito algo assim: "Não há bem escrever, sem estudo e saber" (In: CORRÊA, Discursos, v. II, tomo II: 180).

No terceiro ponto da sua argumentação sobre o "humanismo" na arte literária, Aquino Corrêa não se furta da coloração filosófica do seu discurso, quando questiona e distingue, em "seu humanismo", uma doutrina assentada nos princípios filosóficos de desenvolvimento intelectual, cuja utilidade se poderá inculcar aos novos humanistas, que, "hoje, sobretudo, à míngua de formação filosófica", vão "perdendo tanto em clareza como em profundidade a palavra dos pensadores" (CORRÊA, Discursos, v. II, tomo II: 180).

O tipo de abordagem que fazemos, sobre o humanismo proposto por Aquino Corrêa, esclarece, no discurso crítico do escritor, a seguinte evidência oculta citada por Sócrates: "as opiniões não são verdades, pois não resistem ao diálogo crítico". As opiniões são contraditórias, nós acreditamos saber, mas precisamos descobrir que não sabemos. "A verdade escondida em cada um de nós, só é visível aos olhos da razão" (JAPIASSÚ; MARCONDES, 2004: 251).

No que interessa à crítica literária da poesia, esta máxima socrática traduz a individualidade do poeta expressa, não por uma abstração, mas através de um processo sistematizado e interativo, que tem como resultado o aperfeiçoamento do ser. Apoiado em Horácio (In: CORRÊA, 1985, v. II, tomo II: 181), Aquino Corrêa ressalta que quanto mais o poeta busca aperfeiçoar o seu estilo e a sua forma de elocução, orientando-se em fontes que o influenciaram, mais ele se individualiza e se particulariza 
no interior de um sistema. Quanto mais o poeta desce ao seu particular, mais se individualiza a sua elocução e o seu estilo.

Procurando sempre evidenciar, no discurso crítico de Aquino Corrêa, os aspectos que mais significativamente apontam para uma teoria crítica da poesia, privilegiamos três posicionamentos do escritor os quais nós julgamos atender com maior objetividade os propósitos desta tese.

Aquino Corrêa, pugnando a formação humanística do homem de Letras, que entendemos ser tanto escritor quanto crítico, defende seu ponto de vista apoiado nestes três argumentos: primeiro, os estudos clássicos constituem uma espécie de ginástica intelectual, fundamental na preparação do espírito jovem para toda a atividade futura, ato que traduz para nós a aproximação íntima entre a teoria e a prática, entre o gesto criativo e o gesto teórico. Neste particular, inferimos que formar assim a inteligência, para que possa melhor funcionar, perpassa por processos elaborativos muito mais fecundos que embutir-Ihe muitos conhecimentos, ou, como dizia Montaigne, "mais vale uma cabeça bem feita, que bem cheia” (In: CORRÊA, Discursos, v. II, tomo II: 181).

O segundo argumento de Aquino Corrêa exterioriza um ponto de vista que, ressalta a ignorância da crítica mal fundamentada, que nega a individualidade como fator de particularização do poeta ou da obra no interior de um sistema literário, negando, portanto, a originalidade do poeta, da obra, e até mesmo do sistema.

Só a ignorância ou a má fé pode negar que o trato íntimo com os grandes luminares das duas línguas clássicas seja, por si só, uma escola de beleza literária, insubstituível pelas versões, porquanto, além de que traduções são sempre traduções, e não passam de cópias, que, por melhores que sejam, nunca suprem as originais (CORREA, Discursos, v. II, tomo II: 182).

E, o terceiro argumento volta-se para o material principal da linguagem literária, o ponto de vista de Aquino Corrêa exterioriza um aspecto não menos controverso da crítica literária, ou seja, a questão lingüística. Para o crítico, o conhecimento da língua portuguesa é fundamental para se perceber o funcionamento desta nos estudos críticos literários.

Fiel à sua formação intelectual, o crítico considera que seja inegável a utilidade dos conhecimentos da língua latina e da grega para o conhecimento perfeito da língua 
portuguesa, "a língua vernácula é, para o humanista, o que era a panóplia (armadura) sagrada para os cavaleiros andantes".

Perseguindo o pensamento crítico de Aquino Corrêa, percebemos que a língua não constrói a literatura, mas é ela que a sustenta sob os mais diferentes aspectos. No que compete aos estudos da filologia, reconhece que a cultura se registra e se propaga na imensidade dos documentos efetivamente escritos que a documentam; em relação ao vernáculo, atenta para o que representa uma linguagem isenta de estrangeirismo na representação estética dos elementos nacionais; a gramática entendida como um acordo tácito sobre os fatos da linguagem tanto falada quanto escrita; reconhece a poesia além dos muros do texto, fora do corpo textual, portanto, da palavra escrita ou oral; e a estilística prevendo a capacidade de expressão da poesia através dos mais diferentes recursos, que a língua disponibiliza para a linguagem literária sugestionar ou emocionar.

Para Aquino Corrêa, a língua portuguesa tanto nos seus motivos filológicos, vernáculos, gramaticais como nos estilísticos, é, senão o único, um dos mais importantes fatores sociológicos de coesão entre os povos, de revelação social e cultural dos povos, nos termos em que Santo Agostinho pensava a amplitude da língua: "a unidade e semelhança da língua é o mais forte vínculo da religião e da sociedade humana" (CORRÊA, Discursos, v. II, tomo II:,182).

Uma literatura de base humanística concorre com todos os atrativos e motivos da arte literária para que os homens atinjam a sua perfeição e a sua felicidade. Para Aquino Corrêa, "o homem não é homem pela sua animalidade, nem pelos seus instintos, mas sim pelo espírito, pela racionalidade, pela moral, pela honra, pelo sacrifício no desempenho dos deveres sociais, cívicos e religiosos" (CORRÊA, Discursos, v. II, tomo II: 180).

Segundo o escritor, uma literatura de base humanística não insiste em "frivolidades, mais ou menos elegantes, e sensualidades, mais ou menos pornográficas", ela procura exteriorizar, por todos os meios, o fogo divino pelo ideal, ideal este que se traduz para cada homem, acima de tudo, no próprio aperfeiçoamento do espírito, do caráter humano do homem, que o torne sempre mais homem, isto é, "feito à imagem e semelhança de Deus" (CORRÊA, Discursos, v. II, tomo II: 183). 
Aquino Corrêa afasta-se de um discurso religioso que pode dar à literatura uma aparência transcendental, para aproximar-se de um aspecto da crítica literária que privilegia a capacidade criativa do poeta em criar formas de relações configuradoras do humanismo na literatura. Aquino Corrêa não busca o humanismo aos "fólios hieráticos dos Santos Padres", mas nos versos profanos, citando uma página de Cyrano de Bergerac, o qual, pelo seu claro e poético simbolismo, reputava a mais bela, talvez, de toda a comédia heróica de Rostand $^{56}$, na passagem em que relata o momento em que "os cadetes açoitados pela fome revoltam-se, nada reergue os ânimos, apenas os sons da flauta que Ihes lembrava o país saudoso de Gasconha, erguem-nos, transfigurados, esquecidos dos sofrimentos, e prontos como heróis, encontram a morte no cumprimento do dever" (CORRÊA, Discursos, v. II, tomo II: 183-184).

\subsection{Relações críticas: 0 clássico e o popular / panteísmo e evolucionismo}

Se atentarmos aos encaminhamentos dados para o desenvolvimento desta tese, observaremos que, ao atingir este momento da escrita, enveredamos nas questões mais especificamente relacionadas à linguagem literária, necessitando, portanto, esclarecer o significado de algumas dicotomias com as quais temos de nos familiarizar, para não cometer o disparate de "separar a literatura da cultura e de buscar compreender o fato literário em sua diferenciação, dentro da totalidade da cultura de uma época" (BAKHTIN, 2000: 363).

Embora Bakhtin (2000: 362) tenha deixado de lado os problemas relacionados à crítica literária, alegando que se trata de um campo onde se impõem tarefas de grande importância, ele acentua que a ciência literária deve, acima de tudo, estreitar seu vínculo com a história da cultura. Neste processo de estreitamento entre ciência e

\footnotetext{
${ }^{56}$ Edmond Eugène Alexis Rostand (Marselha, 1 de abril de $\underline{1868}$ - Paris, 2 de dezembro de 1918). Poeta francês. Estudou Direito, mas nunca exerceu a profissão, pois sua verdadeira paixão sempre fora a literatura. Sua obra mais importante é Cyrano de Bergerac (peça de teatro), inspirada na vida de Savinien de Cyrano de Bergerac, escritor francês contemporâneo de Molière e outros. Em 1990 a peça ganhou as telas do cinema, num filme protagozinado por Gerard Depardieu. Gasconha é uma região no sudoeste da França e antiga província francesa.
} 
história, muitos estudiosos se empolgaram com "a especificidade e ignoraram os problemas de interdependência e de interação entre os diferentes campos de cultura" (Op. Cit. p. 362).

Para a crítica literária, a interdependência entre ciência e história se configura na fronteira entre aspectos culturais claramente opostos: clássico/popular e panteísmo/evolucionismo.

No discurso "Gonçalves Dias" (CORRÊA, 1985, v. II, tomo II: 201-207), pronunciado na Academia Brasileira de Letras, no Rio de Janeiro, em 03 de novembro de 1938, lembrando a morte do poeta Gonçalves Dias, Aquino Corrêa lembra o "poeta clássico e popular", dando-nos a dimensão crítica da interdependência, não apenas entre o clássico e o popular, como também entre o panteísmo, traduzido na existência do mundo real, criado por Deus, e o evolucionismo, traduzido como o mundo das idéias, o mundo virtual.

Aquino Corrêa fala-nos do poeta Gonçalves Dias, como o exemplo da junção perfeita entre o clássico e popular, destacando que seus versos "enaltece a vida e conversa o mundo".

No mesmo discurso, Aquino Corrêa destaca que os versos de Gonçalves Dias, ombreados com os de Casimiro de Abreu, Álvares de Azevedo, Castro Alves e Fagundes Varela, exemplificam as fontes que influenciaram na formação do posicionamento crítico do escritor que distingue versos de inspiração religiosa que enaltecem a vida, a pátria e os homens; outros que retratam a "fúria poética" das grandes paixões da mocidade e do pessimismo romântico, e nos põem em contato com esta complexa interdependência conceitual entre o clássico e o popular, o panteísmo e o evolucionismo.

Na referência aos versos de Castro Alves, o "poeta dos escravos", Aquino Corrêa infere a influência social da "sua lira condoreira"; a Fagundes Varela, poeta historicamente assentado na segunda geração romântica, ou de inspiração byroniana, que retoma "a la Gonçalves Dias", no poema Anchieta ou o Evangelho nas Selvas, o tema do índio, já em desuso, infere a visão do mundo exterior do poeta; a Casimiro de Abreu, em seu único livro de poemas As Primaveras (1859), conjugam-se versos que 
traduzem os anseios da juventude, as saudades da infância, compromisso com a terra natal, inferindo-se a expressão legítima da poesia romântica.

São versos que retratam um período em que a matéria poética reflete "desde a vida ao sabor dos caprichos", a refletir-se nas obras poéticas e nos estudos destas obras, "até a morte prematura, a ponto de se abrir um capítulo em nossa história literária, a essa malfadada 'escola de morrer moço', que não é por certo um programa para o nosso patriotismo" (CORRÊA, Discursos, v. II, tomo II: 203-207).

Evidentemente, o que o discurso de Aquino Corrêa traduz, através da figura do poeta Gonçalves Dias, é um período da história literária brasileira em que o nacionalismo era matéria do currículo de qualquer escritor e, este nacionalismo se revelava através da língua, das tradições, da religião e da nacionalidade.

Gonçalves Dias soube ser poeta, sem esquecer a vida, tal como ensinava o bom senso de Boileau - 'ama a virtude e dela nutre tua alma; não sejam os versos a tua eterna tarefa; cultiva os amigos; sê homem de fé; não basta ser encantador num livro, é preciso também saber viver e conversar o mundo'. (...) Dedicado, como, em geral, os seus conterrâneos ilustres, a essas humanidades clássicas....Não deixou de cultivar as línguas modernas e outras matérias, estudando sempre, e tornando-se mesmo um erudito em assuntos históricos e etnológicos brasileiros (CORRÊA, Discursos, v. II, tomo II: 203-204).

Aquino Corrêa critica o uso que fazem da língua portuguesa, afastando-a do seu caráter de representatividade da nação, e ressalta que não entende, por língua nacional, isso a que chamam de língua brasileira, no sentido desse dialeto ou "surrão" já surrado por Ruy Barbosa, "surrão amplo onde cabem à larga, desde que inventaram para sossego dos que não sabem a sua língua, todas as escórias da preguiça, da ignorância e do mau gosto":

Refiro-me, sim, à veneranda e nobre língua portuguesa, essa, que 'com pouca corrupção se crê que é latina', hoje tão nossa, pelo menos, quanto de Portugal, e que transplantada para o céu dos trópicos, desabrochou naturalmente em flores novas, "à semelhança das orquídeas, dos cactos e das passifloras. Esta é a língua de Gonçalves Dias, comparada por Bilac 'à jovem dama das madeixas brancas', língua que enflorada, embora, do viço tropical dos vocábulos indígenas, é sempre a mesma, tem raízes 
no húmus clássico dos mestres de antanho. Daqui a beleza vernácula do seu verso, que sobressaiu desde logo, em meio ao poetar do tempo, à feição de veio cristalino e cantante, a derivar das fontes mais puras do idioma. E como se isso não bastasse, quis 'dar-nos ainda prova mais cabal, nesse curiosíssimo ramalhete de loas, solaus e lendas, que se diriam mimosas flores de herbário, ressuscitadas por milagre da sua arte, nas Sextilhas de Frei Antão, que, escritas em português arcaico, bem revelam a profundeza dos seus conhecimentos da língua pátria. Outra manifestação simpática do nacionalismo de Gonçalves Dias, foi seu amor às tradições, isto é, a tudo que é brasileiro, e o levou a preludiar os "Primeiros Cantos" da sua musa com aquelas poesias americanas, tão originais e tão lindas, que encantaram, como sabeis, a própria crítica sisuda de Herculano" (CORRÊA, Discursos, v. II, tomo II: 205-206).

Aquino Corrêa lembra a matéria que constitui o terceiro elemento do nacionalismo de Gonçalves Dias, que foi a religião, que perpassa "pelos seus carmes, ora subtil e suave como aroma de insenso, ora forte e vibrante, como harmonias mais imponentes do órgão, nas abóbadas de ouro duma basílica", e ressalta que é do escritor, no prólogo dos Primeiros Cantos, este significativo conceito de poesia:

Casar o pensamento com o sentimento, o coração com 0 entendimento, a idéia com a paixão;colorir tudo isso com a imaginação; fundir tudo isso com a vida e com a natureza; purificar tudo com o sentimento da Religião e da Divindade, eis a Poesia, a Poesia grande e santa, a Poesia, como eu a compreendo, sem poder definir, como eu a sinto, sem poder traduzir (CORRÊA, Discursos, v. II, tomo II: 206).

Aquino Corrêa, no discurso de instalação do Grêmio Literário Dom Aquino Corrêa, em Cuiabá, em 20 de abril de 1940 (CORRÊA, Discursos, v. II, tomo II: 231 239), reitera seus posicionamentos críticos sobre o clássico e o popular, o panteísmo e o evolucionismo, dando mais consistência ao nosso argumento em relação à dimensão crítica da interdependência não apenas entre o clássico e o popular, como também da religião e da ciência.

Os posicionamentos críticos sobre uma literatura que leva em conta os contatos, ou que sejam os 'exemplos sumos', reiteram-se, neste discurso através da citação das 
figuras de João Bosco ${ }^{57}$ e São Francisco de Sales ${ }^{58}$. Segundo Aquino Corrêa, João Bosco, o fundador da Congregação Salesiana pertenceu à Arcádia Romana, a famosa Academia de Letras, que, além do mais, teve notável repercussão nos fastos da literatura luso-brasileira.

Aquino Corrêa faz notar que, pelos ambientes da Arcádia, perpassa um largo sopro de Renascença, que foi, conforme informa o escritor, "a ressurreição da arte pagã, a evocar o país idílico de Pan e dos pastores, com todo o simbolismo poético dos seus mitos", e nem por isso, D.Bosco desdenhou o título acadêmico de árcade, com o solene pseudônimo pastoril de Clístenes Cassiopeu.

Na referência a Francisco de Sales, Bispo e Príncipe de Genebra, Aquino Corrêa vai, mais além, esclarecendo que o escritor timbrou em ser um "verdadeiro homem de letras", fundou uma sociedade literária e deu-Ihe o sugestivo nome de "Florimontana", porque se destinava a enfeixar as "flores da montanha", cultivando tanto as 'flores do estilo' como os "frutos de idéias úteis e salutares", isto é, os melhores letrados da sua montanhosa e dileta Sabóia (Itália). A afirmação de Francisco de Sales reforça o posicionamento de Aquino Corrêa em relação a uma linguagem literária que nunca envelhece:

Cultivai, pois, cultivai, desde cedo, ó jovens, as flores do estilo. Mas flores são estas, que não desabrocham, frescas e louçãs, senão em jardins adubados com o humo rico duma linguagem castiça, carreada pacientemente dos repositórios clássicos do idioma". "Dir-vos-ei, portanto, como o poeta Francisco de Sales: Abra-se a antiga e veneranda fonte dos genuínos clássicos e soltem-se as correntes da antiga e sã linhagem! (CORRÊA, Discursos, v. II, tomo II: 236).

Satirizando um momento da cultura nacional, em que os estrangeirismos se constituíram como ponto fundamental de discussão em torno da pureza da língua portuguesa, Aquino Corrêa pronuncia-se contrário a esta "moda", por entender que, no mundo das ciências e das letras não há espaço para "insinuantes barbarismos".

\footnotetext{
57 João Bosco- precursor das missões salesianas.

58 São Francisco de Sales- é titular e patrono da família salesiana (fundada por São João Bosco), também patrono dos escritores e dos jornalistas.
} 
Citando Filinto Elíseo ${ }^{59}$, Corrêa (1985 e, v. II, tomo II: 236) acrescenta que é necessário desempoar-se da estrangeira frase, visto que esta traduz uma imagem do estrangeiro nas letras nacionais. Em relação às ciências, Corrêa esclarece que esse tipo de discurso deve se sustentar em termos lingüísticos, que traduzem objetividade e universalidade.

A título de ilustração, de um aspecto que consideramos essencial, ter a língua literária como o veículo maior de expressão de uma nação, fazendo jus à máxima de Goethe, de que "nenhuma nação está disposta a renunciar a sua individualidade" (In: WELLEK e WARREN, 2003: 50), transcrevemos o poema de Filinto Elíseo "A língua portuguesa e a latina":

Já me fizeram cargo os meus censores de ter muito latim portuguesado.

Mais honra me fizeram que eu mereço. em dar sobejo preço os tais senhores, dar sobeja importância a quatro trovas que nuns borrões lancei por desenfado. e à luz dei só por míngua de dinheiro. Mas, pois tão alto vai esse arruído, permitam-me acudir por meu cliente. Se cunho português dei a latinas vozes, e é crime pôr-lhe cunho alheio. réus desse crime são quantos escrevem depois de tantos séculos na Europa, que co roubado estafo dos Romanos cobriram a nudez desses vasconços. que com vil lodo a face enxovalhavam da terra, a sáfios bárbaros sujeita.

Réu quero, como Camões, ser desse crime voluntário e não dar francês bastardo. qual dá da nova seita o soez cardume. Sujeita à antiga Europa à antiga Roma, falou polida a língua vencedora; vencidos os Romanos pela bronca, hiperbórea relé, Sicambros, Cimbros, nós, Lusitanos, com farragem goda logo a latina tela entretecemos;

${ }^{59}$ Filinto Elíseo (1734-1819), pseudónimo do Padre Francisco Manuel do Nascimento, foi um dos mais importantes poetas do Neoclassicismo português. Apesar de ser clérigo, lendo livros racionalistas franceses proibidos pela Inquisição, teve de fugir para França, exilando-se em Paris, em 1778. 
e, não contentes inda, a bordadura de engasgado mourisco the cosemos, coa franja multicolor de tantas línguas, quantas não deu Babel, no louco arrojo de querer ter mirante sobre as nuvens.

Convinha povoar as terras ermas das gentes que segou a fronte avara dos belicosos reis conquistadores. Chamaram-se de incógnitas províncias povos de estranhas línguas, que o tecido da nossa com mais tinta alagartaram Eis que começa de apontar na Itália das boas letras a bem-vinda aurora. Acorrem de um e de outro reino a ela os moços, de ciência cobiçosos:

abraçam com ardor as doutas línguas e vêm contentes derramar seu lustre pelo escuro sertão do pátrio idioma. Resta agora entender se foi acerto nos que a língua tão rude nos poliram co romano esmeril, tornando-a ao grêmio da perdida opulência, ou se deixá-la no vândalo paul, suevo ou gado.

Quem não diz que mais val desbastar hoje do bárbaro falar a língua lusa. introduzindo os termos da latina que o vasconço primevo desbastara, que estragá-la com vozes alforrecas: babugem que nas ribas portuguesas lança a lição de sécios bonifrates, que de alheio país só balbuciam geringonça bastarda, mal intrusa? Muitos que hoje escrevem franceseiam; francesear agora é tão absurdo, quanto o fora nos séculos latinos vandalear, falar suevo ou godo. Francesear em língua portuguesa se atrevem quatro tolos vangloriosos de uns laivos, que puseram mal assentes na Face maternal, que se envergonha. ${ }^{60}$

Apoiados, ora nas premissas do poeta Horácio, segundo as quais "saber e pensar bem é princípio e fonte do bem escrever", e "uma vez bem sentido e meditado o assunto, virão por si mesmo as palavras"; ora em Boileau, que estabelece o princípio de que "para avançar na escrita, aprenda a pensar!"; ora na de Castro Alves, que defende

\footnotetext{
${ }^{60}$ Fonte: http://alfarrabio.di.uminho.pt/vercial/filinto.htm
} 
que os livros ensinam-nos a pensar e "Ó, bendito o que semeia livros, livros à mão cheia, e manda o povo pensar!"; ora na de Catão ${ }^{61}$, na tese: "apodera-te do assunto, que as palavras virão após", e por fim, na de Cícero ${ }^{62}$, para quem "as próprias idéias arrastam consigo as palavras", Aquino Corrêa fundamenta o seu posicionamento crítico sobre a forma de se compreender a obra literária a partir da compreensão do sentido expresso pela sua textualidade:

É, pois, necessário sentir: quem não sente, não tem fantasia, e sem esta, mal se compreende a obra literária. Não basta, porém, sentir, é preciso meditar, ou pensar. Sentir é próprio do animal; pensar é do homem. Sentimento sem reflexão é o cavalo selvagem de Mazepa; sentimento guiado pela meditação é o ginete árdego, mas elegante, dos paladins em torneios de cavalaria. Nada mais belo que um moço, que sabe pensar! (CORRÊA, Discursos, v. II, tomo II: 237).

\subsection{Letras e imortalidade}

Retomamos o discurso crítico de Aquino Corrêa em "Mensagem aos homens de Letras" (CORRÊA, Discursos, v. II, tomo II: 175-184), proferido no Rio de Janeiro, em 14 de janeiro de 1937, constituindo-se como fonte reveladora do posicionamento crítico do escritor em relação ao papel desempenhado pelos escritores e academias na edificação da cultura nacional.

Segundo o escritor, "estar na Academia Brasileira de Letras, embora fechados

neste breve recinto", os escritores representam vozes, e são ouvidos por "toda a intelectualidade da nossa Pátria". Claro que isso não se deve ao milagre e poder misterioso do rádio, da mídia, este "ser ouvido" significa que cada nome na Academia representa a "flor do pensamento nacional", e, o que ele escreve, tem significação, atrai "as atenções do nosso mundo bem pensante, que em meio à tempestade das paixões e

${ }^{61}$ Catão- enciclopedista, estadista e general romano, conhecido como o "Velho" ou o "Censor", famoso pela austeridade de seus princípios. Dedicou-se a combater as influências gregas em Roma, por acreditar que estas traziam marcas de desnacionalização.

${ }^{62}$ Cícero- Marco Túlio Cícero. As idéias de Cícero sobre a arte da oratória, assim como a história desta, ele as expressou em tratados escritos de forma dialogada. Cícero desenvolveu a prosa latina até a levar à sua perfeição, do mesmo modo que Virgílio e Horácio o fizeram com a poesia. 
críticas desencontradas acende em vossas frontes os santelmos ${ }^{63}$ luminosos da admiração e da glória" (CORRÊA, Discursos, v. II, tomo II: 175).

Este enfoque nos coloca no interior daquilo que consideramos uma grande metáfora: as academias, como o espaço de congregação da intelectualidade, daqueles que, em meio à tempestade das paixões ideológicas e das críticas desencontradas, acendem em "vossas frontes, os santelmos luminosos", talvez nem tanto de admiração e de glória, como apregoou Aquino Corrêa (1985), com sua "linguagem empolada", mas também de críticas, por vezes virulentas, que, na conclusão, sempre se traduzem em algum tipo de "luz" ou de "iluminação" que rompe com toda unanimidade, e que, segundo Nelson Rodrigues, "é burra". Afinal, apenas a diversidade é o que atrai e suscita atualização.

Aquino Corrêa argumenta em favor das academias, sustentado em dois receios: a princípio, diante da responsabilidade intelectual de cada acadêmico em saber discernir a discussão vazia de acontecimento cultural e a discussão que prima em elevar a palavra, receando não "profaná-las em discussões que não passam de questões que vão apenas da ortografia à sintaxe, ou da filologia à estilística"; e em segundo, discutir sem racionalidade, ancorado apenas na subjetividade:

de outro lado, porém, tenho medo de entrar aqui em teses, que entendam com a vida, e, por isso mesmo, com a moral e a religião, visto que esta assembléia traduz "todos os intelectuais do Brasil", alguns dos quais sorriem diante da convicção dogmática, com que soem os católicos versar matérias de fé e de costumes (CORRÊA, Discursos, v. II, tomo II: 175).

Visto que, neste ponto, partimos da figura do escritor como o artífice da linguagem, em direção a uma abordagem crítica da língua literária, consideramos as palavras transformadas em "símbolos"64, vistos como os "elementos necessários para esclarecer a função simbolizante da imaginação" (CHEVALIER, 2000: 632), materializados através da língua.

${ }^{63}$ Santelmo: na Mitologia, é o santo invocado pelos marinheiros do Mediterrâneo por ocasião das tempestades, aparecia como uma chama. Cientificamente, chama-se santelmo a chama produzida por eletricidade que aparece no topo dos mastros dos navios.

${ }^{64}$ CHEVALIER, Jean,Dicionário de Símbolos: (mitos, sonhos, costumes, gestos, formas, figuras, cores, números),CHEVALIER; Jean, GHEERBRANT, Alain.Colaboraçã: André Barbault...[et al.]; coordenação : Carlos Sussekind; trad.Vera da Costa e Silva...[et al], ed.15. Rio de Janeiro: José Olímpio, 2000. 
Sob esta ótica, torna-se imprescindível perceber a academia "por dentro", nos termos referidos em nossa dissertação de mestrado ${ }^{65}$, enquanto espaço de institucionalização da literatura, ou seja, uma "instituição" que, nos seus contornos protocolares compreendidos através dos discursos acadêmicos de posse, elogio e recepção ${ }^{66}$, trata de "promover a aproximação simbólica da cultura de diferentes épocas e espaços, através de diferentes vozes, procurando manter o fio de atualização constante das mudanças" (DELBEM, 2002: 56).

Nesta visão, em que os vultos e as idéias do passado são traduzidos através dos procedimentos protocolares dos escritores, revelados nos textos dos discursos acadêmicos, reveladores do diálogo entre o passado e o presente, a memória tem a função social de atualizar o passado através de uma inteligência do presente. Neste caso, Ecléa Bosi (1994) argumenta que

Não há evocação sem uma inteligência do presente, um homem não sabe o que ele é se não for capaz de sair das determinações atuais. Aturada reflexão pode preceder e acompanhar a evocação. Uma lembrança é diamante bruto que precisa ser lapidado pelo espírito. Sem o trabalho da reflexão e da localização, seria uma imagem fugidia. O sentimento também precisa acompanhá-la para que ela não seja uma repetição do estado antigo, mas uma reaparição (BOSI, 1994:81).

Nesta linha argumentativa, retomamos o discurso de Aquino Corrêa, que cita o caso ilustrado por Humberto de Campos $^{67}$, que satirizou a linguagem do discurso de posse do segundo arcebispo a tomar posse na Academia Brasileira de Letras, e a qual

\footnotetext{
${ }^{65}$ DELBEM, Nancy Lopes Yung. Imortalidade e discursos: a presença lusitana e a língua portuguesa no espaço cultural de Mato Grosso. São Paulo: 2002. 272 f. Dissertação (Mestrado em Estudos Comparados de Literaturas de Língua Portuguesa) - Faculdade de Filosofia e Ciências Humanas, Universidade de São Paulo.

${ }^{66} \mathrm{O}$ discurso de posse é pronunciado pelo acadêmico novel e nele se realiza o elogio ao patrono da cadeira que o mesmo irá ocupar na Academia; o de recepção é proferido por um acadêmico veterano que recepciona o novel.

${ }^{67}$ Humberto de Campos (1886 - 1934) - Mesmo sem estudos, Campos foi um dos grandes autores brasileiros, mesmo que seus escritos não tenham o merecido destaque. Inovou nas crônicas, adicionando ao estilo, novos elementos. Quando adoeceu, mudou completamente seu estilo: de mordaz e cômico, transformou-se num arauto em defesa dos menos favorecidos, encontrando agora consolo por parte dos mais pobres.
} 
Aquino Corrêa entendeu como uma "sátira à maneira de Horácio, que usava para chibatear uma vergasta de rosa" (CORRÊA, Discursos, v. II, tomo II: 175). Segundo Campos, "entre outras coisas mais sérias, o arcebispo não tergiversara sequer, no discurso de posse que proferira na Academia Brasileira de Letras, em condenar, perante um público de pecadores elegantes, a beleza literária inspirada pelo pecado. Em seu artigo, aludindo aos dois arcebispos acadêmicos, Humberto de Campos assim classificava o quadro de acadêmicos da Academia: “(...) são assim, na lista acadêmica, os únicos filhos legítimos de Deus e da sua Igreja (referindo-se aos dois arcebispos); alguns outros são filhos naturais da Igreja ou de Deus; e o resto, ali, pertence ao Diabo" (CORRÊA, Discursos, v. II, tomo II: 175).

Ponderando a sátira de Humberto de Campos, Aquino Corrêa considera necessário "distinguir sempre", fazer a distinção gerada pela palavra mais complexa da linguagem polêmica, a intolerância, é precisamente, a intolerância, a qual para maior clareza ou efeito mnemônico, Aquino Corrêa a designa e explicita por "três pês": intolerância de pessoas, de palavras e de pensamentos (CORRÊA, Discursos, v. II, tomo II: 176).

Para ilustrar a intolerância das pessoas, Aquino Corrêa cita uma passagem bíblica, dos Evangelhos, em que Jesus levou a tolerância às pessoas a tal auge que escandalizou os fariseus, pois, afrontando-lhes, embora a indignação e o desprezo, achegou-se aos publicanos e pecadores (CORRÊA, Discursos, v. II, tomo II: 176).

A relação desta passagem com a Academia de Letras remete-nos à questão da diversidade existente no interior desta instituição. Carlos de Laet $^{68}$ é o acadêmico que melhor expressa este quadro, quando coloca que "neste habitáculo de letras, a tolerância de pessoas não é somente uma virtude, mas uma exigência impreterível, para a serenidade dos debates, mesmo naqueles que mais nos encandeiam, isto é, os da questão ortográfica" (CORRÊA, Discursos, vol II, tomo II: 176).

\footnotetext{
68 Carlos de Laet (1847 - 1927) - deixou uma vasta produção de páginas sobre arte, história, literatura, crítica de poesia e crítica de costumes. Diz-se que foi reacionário porque ironizou e combateu o Modernismo, tendo-Ihe escapado o sentido vanguardeiro e renovador, do movimento nascido em São Paulo, com a Semana de Arte Moderna. Graça Aranha foi alvo de suas críticas e zombarias, tendo-lhe fornecido assunto para três sonetos galhofeiros. É preciso não esquecer, porém, que Carlos de Laet nascera em 1847, sendo, portanto, compreensível que, educado numa cultura clássica, e já beirando os 80 anos, não tenha compreendido a nova corrente de idéias suscitada pelos iconoclastas de 1922.
} 
Em relação à intolerância de palavras, Aquino Corrêa alude ao estilo particular de cada escritor compreendido a partir da sua formação e inserido nos preceitos de uma determinada "escola" literária. Neste aspecto, o escritor argumenta que a "intolerância às palavras" expressa toda a "intolerância ao modo particular com que cada um expõe ou defende suas idéias" (CORRÊA, Discursos, v. II, tomo II: 177). Para o crítico, a escolha das palavras e a identidade entre pessoas e palavras é um processo subjetivo e livre ao qual se aplicam, inclusive, os "floreios elegantes da dialética" assentados na "firmeza da verdade e na gentileza ao defendê-la".

Em relação à intolerância ao pensamento, Aquino Corrêa adota o princípio de que "não há condescendências nem amizades que valham justificar a adoção do erro, um só que seja. Já dizia Aristóteles que, embora sendo "amigo e admirador de Platão, não deixava de o ser e muito mais, da verdade". Tal argumento traduz a idéia de que ser amigo não se confunde com a convicção com que se defende o pensamento particular, conforme o dizer de Pascal ${ }^{69}$ : "tolerar idéias contraditórias é próprio só dos espíritos que ainda não se firmaram na verdade" (CORRÊA, Discursos, v. II, tomo II: 178).

Sob o prisma da crítica literária, Aquino Corrêa defende a fórmula clássica de Santo Agostinho, segundo a qual, "deve-se amar os homens, destruir os seus erros, com a certeza, mas não soberbos de possuir a verdade absoluta, lutando sempre, mas sem paixões radicais" (CORRÊA, Discursos, v. II, tomo II: 178).

Esta abordagem referenciada na "intolerância" circunscreve-se aos domínios do dogma, o que, segundo Aquino Corrêa, cerceia a liberdade do homem, e que, somente fora do dogma é que há liberdade de pensamento, princípio fundamental de qualquer manifestação artística. Apoiado em Santo Agostinho, afirma que "no dogma há unidade, na dúvida há liberdade e em tudo há caridade" (CORRÊA, Discursos, v. II, tomo II: 178).

Circunscrito ao macrossistema literário e à plenitude humana da liberdade de pensamento, Aquino Corrêa ressalta que o tema que mais de perto lhe interessa "assunto vivo e fresco de atualidade", movimento eminentemente literário, que se the

${ }^{69}$ Pascal (1623 - 1662) - O que nos interessa em Pascal, nesta hora, é a defesa que este faz do princípio de que a riqueza humana consiste justamente em se aprofundar em aspectos individuais e sociais que estejam de acordo com o real, sem esgotar o diálogo que cada um tem consigo mesmo e com o outro. 
afigura, hoje, uma destas correntes do pensamento universal, que, por mais vezes orienta a alta mentalidade de toda uma época da história é o "moderno humanismo", assim chamado

pelas afinidades com a escola dos humanistas do século XV, que fizeram a Renascença, que, outra coisa não foi senão um 'retorno à cultura clássica', onde o espírito daquele século fora buscar, nas inspirações das musas gregas e latinas, o prazer de uma beleza menos abstrata, nas letras e nas artes em geral (CORRÊA, Discursos, v. II, tomo II: 179).

Como entre os latinos estes estudos literários se chamavam "humanos", daí derivou-se o nome de "humanistas" aos próceres do Renascimento. Segundo Aquino Corrêa, "os velhos humanistas" não acentuaram bem o caráter humano da cultura literária, a que se dera o nome de "humanidades", por isso mesmo é que, estes estudos devem tornar o homem mais humano, aperfeiçoando nele o que o distingue dos demais animais. Nisto é que se estabelece a diferença entre o antigo e o novo humanismo. $\mathrm{O}$ humanismo contemporâneo caracteriza-se por ter como finalidade suprema a "perfeição humana", mesmo que nem todos convenham no mesmo sentido, ou no conceito dessa perfeição, ela não pode deixar de ser o ideal de toda escola literária ou artística" (CORRÊA, Discursos, v. II, tomo II: 179).

Aquino Corrêa nomeia três obras, nas quais se apóia para resumir a tendência humanista da literatura, neste momento de atualizações (CORRÊA, Discursos, v. II, tomo II: 179): a obra de Charmot, intitulada L'humanisme et l'humain (1934), que lança os princípios da nova escola e suas atinências com o humanismo de antes; a obra Humanisme Integral, de Jacques Maritain (1936), em que o autor tira as últimas conseqüências do moderno humanismo, na sua fecundidade integral a bem da humanidade; e, L'homme, cet inconnu, de Aléxis Carrel (1950), em que se sente a repercussão do humanismo nas ciências médicas.

Perseguindo o pensamento do escritor em relação ao humanismo, cuja definição é desenvolvida seguindo linhas bastante divergentes, concluímos que o humanismo 
integral, proposto por Jacques Maritain ${ }^{70}$, tende, essencialmente, a tornar o homem mais humano, e a manifestar sua grandeza original, fazendo-o participar de tudo que pode enriquecê-lo na natureza e na história, exigindo ao mesmo tempo que ele desenvolva as virtualidades nele contidas, suas forças criadoras e a vida da razão, e trabalhe por fazer, das forças do mundo físico, o instrumento de sua liberdade ${ }^{71}$, é o que sustenta a visão humanista de Aquino Corrêa.

Assim entendido, o humanismo é inseparável da civilização ou da cultura, portanto, o humanismo ocidental tem fontes marcadamente religiosas e "transcendentes", sem as quais seria incompreensível, visto que o termo "transcendente" traduz todas as formas de pensamento, quaisquer que sejam as suas diversidades, que põem, na origem do mundo, um espírito superior ao homem, e, no homem, um espírito, cujo destino vai além do tempo, e uma piedade natural ou sobrenatural que o coloca no centro da vida moral.

As fontes do humanismo ocidental são também fontes clássicas e fontes cristãs, e não somente na massa da Antigüidade pagã, aquela que evoca os nomes de Homero, Sófocles e Virgílio, que aparecem os caracteres de fonte de origem do humanismo integral de Jacques Maritain ${ }^{72}$.

Esta recorrência ao humanismo sustenta a nossa visão de análise da temática humanística desenvolvida por Aquino Corrêa, ao mesmo tempo que dá o suporte necessário para se pensar a língua literária , como representação social e o material lingüístico, com que o escritor escreve as suas obras e expõe suas idéias em relação aos gêneros e ao estilo literários.

\subsection{Questão de gênero e de estilo}

É o juízo crítico de Carlos Ceia ${ }^{73}$, sobre os gêneros literários e os "modos de produção do literário", que nos possibilitou encontrar o lugar de Aquino Corrêa como precursor de uma corrente de estudos literários que prevê criticamente as formas de

\footnotetext{
${ }^{70}$ MARITAIN, Jacques. Humanismo Integral. Trad. De Afrânio Coutinho. São Paulo: Companhia das Letras, 1945.

71 MARITAIN, Jacques. Humanismo Integral:introdução, heroísmo e humanismo-noção geral do humanismo. In. http:www.maritain.org.Br/livros/HI_introdução.htm (11/09/06)

72 http:www.maritain.org.Br/livros/HI_introdução.htm (11/09/06)

${ }^{73}$ Carlos Ceia é professor de Literatura Inglesa e Teoria Literária, na Universidade de Nova Lisboa, na Faculdade de Ciências Sociais e Humanas. Autor de ensaio, romance e poesia.
} 
produção literária de Mato Grosso. Segundo Aquino Corrêa (1985 b: 17), "...as coisas belas são difíceis de realizar e mais difíceis ainda de analisar cientificamente".

Para Carlos Ceia, sendo o gênero literário uma forma de classificação dos textos literários agrupados por suas qualidades formais e conceituais, em categorias descritas por códigos estéticos específicos, desde a Poética de Aristóteles, e pelos tratados de retórica de Horácio, Cícero e Quintiliano até as modernas monografias sobre teoria da literatura, percebemos que, na cultura ocidental, até o século $X X$, não se faz qualquer distinção entre as categorias fixadas historicamente como o romance, o conto, a novela, tragédia, comédia, elegia, ode, epopéia e cantiga, e a sua explicação fenomenológica, não datada historicamente, nos conduz à reflexão sobre os modos de produção do literário (modo narrativo, modo lírico e modo dramático).

Assim, procuramos perceber, nos diferentes códigos ou tratados sobre a natureza da poesia e suas concretizações, que o gênero literário é em si mesmo um universo para onde convergem todas as questões ontológicas e epistemológicas sobre o fenômeno literário, incluindo as discussões sobre a tradição, a memória, a originalidade, a verossimilhança, a imitação, etc. Contudo, as mais recentes propostas no campo da teoria da literatura recomendam a distinção entre gêneros literários como categorias históricas do texto literário e "modos literários", ou seja, formas metahistóricas ou arquitextuais de concretização do literário.

Segundo Wellek e Warren (2003), os gêneros literários são formas discursivas históricas que não devem ser confundidas com as suas formas a-históricas (gêneros fundamentais), e distingue as três etapas da história da teoria dos gêneros literários: a primeira fase, chamada de "clássica", vai de Platão, com o seu Livro II, da República, e Aristóteles, com a sua Poética até o Neoclassicismo romântico; a segunda fase vai da estética de Hegel até os poetas ingleses, para os quais é exemplo o Preface to lyrical Ballads (1768), de Willian Wordsworth, que ignora, premeditadamente, o problema dos gêneros nesse texto programático; e, por último, a fase que vai do formalismo russo, do princípio do século $\mathrm{XX}$, até os dias atuais.

Retomando o posicionamento crítico de Carlos Ceia (2006), de acordo com os estudos efetuados, percebemos que as diferentes teorias sobre os gêneros literários 
evoluem em torno de um denominador comum de reflexão, que é sobre "o que é que representa o literário e como é que essa representação se produz".

Assim, desde Platão se propõe que todo texto literário é uma narrativa ou diegesis de acontecimentos concretizados em três modalidades: por um simples ato narrativo dominado pelo discurso em primeira pessoa do narrador-poeta; por um ato mimético (a mimesis) dominado pelo discurso em terceira pessoa das personagens (como nas tragédias e nas comédias); e por um modo misto que combina 0 ato narrativo (em primeira pessoa) e o ato mimético (em terceira pessoa), alternando vozes do narrador-poeta e das personagens, até Aristóteles que propõe uma teoria dos gêneros literários que distingue os modos literários (a imitação narrativa que produz o literário) e as diferentes formas de representação textual que resultam do processo mimético (terceira pessoa), estabelecemos uma distinção entre os modos literários e as diferentes formas de representação textual que resultam do processo mimético artístico, ou seja, as formas de elaboração textual utilizada pelo escritor.

É exatamente nesta confluência em que percebemos a fronteira distintiva entre as categorias genéricas (dos gêneros literários) e as categorias estilísticas ( do estilo individual ou do estilo de época) da arte literária, que inserimos os nossos estudos a partir de Aquino Corrêa, como aquele que defende um paradigma centrado na "beleza da forma e da matéria", para criticamente pensar o lugar do poeta e as produções literárias de Mato Grosso.

No início da Poética, Aristóteles anuncia que vai falar da "poesia" e das "espécies" ", entendendo-se, através desta tradução feita por Eudoro de Sousa, que a arte da poesia se concretiza em diferentes modalidades ou espécies, com características particulares, isto é, os gêneros, a partir de um único modo de realização, a mimesis.

Para Aristóteles, toda poesia é imitação, que se encontra nas diferentes "espécies" ou nos gêneros literários. E, o que nós entendemos como "liberdade de expressão" , é o modo particular de cada artista expressar uma particularidade que traduz, a princípio, seu modo de sentir a matéria poética, a afetividade, e, depois, a sua opção formal, ou o poder de escolher a forma que dará corpo à matéria poética.

${ }^{74}$ Poética, tradução de Eudoro Sousa, (Lisboa, 1964,1994). 
A partir dos postulados críticos de Aquino Corrêa (1985), buscamos o princípio teórico de Benedetto Croce $^{75}$, que, em termos atuais, chama a atenção para os estudos sobre a gênese dos gêneros literários, muito mais preocupados em saber se um texto está conforme as convenções do gênero a que este está filiado, do que em saber o que este texto significa, no contexto em que ele foi gerado.

Croce $^{76}$ aceita a utilidade dos gêneros literários na sistematização da história literária, desde que não sirvam para abstrações e generalizações que acabm por sacrificar os melhores autores da literatura (In: CEIA, 2006).

Concluindo, Carlos Ceia (2006) explicita que, dado o caráter dialogante da teoria dos gêneros literários, que proporciona reflexões muito díspares entre si, por força da ligação que o fenômeno literário sempre terá com a criatividade artística, cada época constrói os seus códigos e, à medida que a modernidade se afirma, poucos artistas resistem ao desafio das convenções clássicas.

Evidentemente que este juízo crítico implica a consideração de que a modernidade, configurada por uma nova situação histórica, se marca pela liberdade de expressão, não se evidenciando nenhuma necessidade de eficazes sistematizações do literário ou determinações normativas radicalizantes para descreverem as suas estruturas internas, segundo princípios estéticos característicos de determinadas realizações textuais.

\footnotetext{
${ }^{75}$ Benedetto Croce - crítico italiano que juntamente com o francês Ferdinando Brunetière desenvolveram estudos sobre a gênese do gênero literário, marcando os estudos, neste sentido, no século XIX (In: Carlos Ceia, 2006).

${ }^{76}$ CROCE,Benedetto. Estética: come scienza dell'espressione e lingüística generale: teoria e storia. Milão: Adelphi, 1990, 1.ed.,1902)
} 


\section{CAPÍTULO 6}

\section{Língua literária em uso: estratos da obra de arte, normas e métodos}

Em termos de norma lingüística, o moderno foi a depuração dos excessos, tanto da linguagem revolucionária, quanto dos resíduos lusófilos, e a adoção do padrão brasileiro na língua literária (Marli Quadros Leite, 2006: 63).

À luz da crítica, distinguem-se na obra literária duas entidades, a forma e a matéria ou fundo, assim também resplandecem nela duas belezas: a beleza da forma e a beleza da matéria.Cultivá-las ambas, eis a missão do Centro Mato-Grossense de Letras (Aquino Corrêa, 1985 b: 18). 
A escolha minuciosa dos dois textos, que se constituem como epígrafes deste capítulo, teve como base uma afinidade teórica e crítica, defendida por nós, e evidenciada por Leite (2006) e por Corrêa (1985 b), que, além do fato de evidenciarem, de forma clara, os traços de uma língua literária subordinada à existência de uma "norma lingüística" própria, que, de um lado promove a depuração dos excessos da linguagem revolucionária dos modernistas e dos resíduos lusófilos dos tradicionalistas, do outro lado, subsidiam a crítica literária, no sentido de evidenciar que, na realidade, quando tratamos de literatura e estudos literários, é o prisma literário que interessa, tratando a beleza literária subordinada à beleza da forma e à beleza da matéria.

Sob a luz deste princípio crítico, e de acordo com os estudos apresentados, concebemos a obra literária conforme as orientações teóricas de Wellek e Warren (2006:200), segundo as quais, a obra de arte surge como um objeto de conhecimento 'sui generis', que tem sua própria condição de existência, não é real, fisicamente assemelhada a uma escultura, nem mental, psicologicamente entendida como uma experiência de luz ou dor, e nem ideal, exata como um triângulo.

A obra de arte é concebida pelos críticos como um sistema de normas de conceitos ideais que são intersubjetivos. Por este pressuposto, afirmamos que as obras de arte literária encerram relações íntimas, subjetivas e cooperativas entre o artista e o leitor. Estas relações são de cognição e de afetividade, e são manifestadas através de leituras que traduzem muito mais tensões do que lugares comuns ou o óbvio. Por existirem como formas particulares de representação da ideologia coletiva, as obras de arte mudam conforme muda a ideologia, tornando-se acessíveis, apenas através das experiências individuais de leitura do autor, que incluem a obra materializada tanto na estrutura sonora das suas sentenças como na experiência individual dos leitores e dos estudiosos da obra literária.

Perseguindo este pressuposto, uma crítica literária consciente não discute a questão de valores artísticos configurados fora dos estudos analíticos da obra literária. A crítica assentada no estudo analítico mostra que não há nenhuma estrutura artística fora das normas e dos valores, os quais são imprescindíveis à crítica para analisar uma obra de arte e atribuir-Ihe as significações pertinentes ao sistema e adequadas ao contexto em que esta foi gerida, e que sustenta a sua sobrevivência. 
O que depreendemos desta constatação é que o sistema literário se constitui e sofre acréscimos constantes, a partir do surgimento de novos paradigmas advindos de posturas ideológicas distintas.

\subsection{Estratos da obra literária e paradigmas de estudo analítico do poema}

Assentados sob o lema da Academia Mato-grossense de Letras Pulchritudinis studium habentes -- "Estudiosos da beleza", procuramos sustentar ao longo do trabalho aquilo que Aquino Corrêa postula em relação à arte literária em Mato Grosso: uma literatura "que eduque, edifique e eleve" (CORRÊA, 1985 b: 26).

Entendemos deste lema a preocupação do escritor em dar uma visão epistemológica à obra de arte literária, aliada a um princípio crítico em face dos estudos literários. Esta visão contempla a adoção de um comportamento crítico e analítico diante da obra, subordinada a uma norma lingüística que possibilita perceber a função da língua literária no entendimento de uma "modernidade" situada na fronteira da "depuração dos excessos", tanto de uma linguagem revolucionária proposta pelos modernizadores das letras, como dos "resíduos lusófilos" preservados pelos tradicionalistas.

A metodologia adotada para a execução desta tese, assentada sob a bandeira dos estudos analíticos do poema, possibilitou-nos entender que o equívoco dos estudos críticos da fenomenologia pura está na suposição de que é possível dissociar, na obra de arte, uma estrutura ou uma forma, e o juízo de valor desta estrutura no interior do sistema.

Este segmento da crítica considera que os valores artísticos sobrepostos, na "estrutura", são "inerentes" dela ou a ela, supondo-se uma "escala de valores" absoluta, sob a qual a criação literária se subordina. O que se infere desta consideração é que a obra literária vista sob este ângulo perde o contato com a relatividade dos julgamentos individuais, a que uma obra de arte está sempre exposta. Esta constatação coloca as obras de um determinado sistema literário como "um absoluto congelado", que enfrenta um fluxo sem valor de juízos críticos individuais. 
Wellek e Warren (2006) argumentam que "a tese insensata do absolutismo" dos valores inerentes à obra literária, e a "antítese igualmente insensata do relativismo" dos valores da obra literária em relação a outras, "devem ser superadas e harmonizadas em uma nova síntese, que dinamize a própria escala de valores da obra literária" e dos estudos inerentes a ela, de forma que não se renuncie à obra como tal.

Esta tendência, que os críticos denominaram sugestivamente de "perspectivismo", não significa anarquia de valores ou talvez, uma glorificação do capricho individual, conveniente a um estrato ou a uma época, principalmente nestes tempos em que a mídia decretou o fim das fronteiras fixas, o que ela traduz é um processo que possibilita o conhecimento do objeto estético, a partir de pontos de vista diferentes, que, podem ser definidos e criticados. Para os teóricos, a estrutura de uma obra, a sua significação e os valores a ela atribuídos formam "três aspectos do mesmo problema e não podem ser isolados artificialmente" (WELLEK e WARREN, 2006:200).

$\mathrm{Na}$ altura dos encaminhamentos necessários ao desenvolvimento desta tese, perseguindo o pressuposto maior de Aquino Corrêa, de que a beleza literária se assenta indistintamente na beleza da forma e da matéria poéticas, torna-se necessário destacar a importância do estudo intrínseco da obra literária para, a partir deste ponto, compreendermos a interpretação e a análise das obras como o húmus dos estudos para uma teoria da crítica literária da poesia.

Segundo Wellek e Warren (2006), os oito estratos que seguem: (1) o sonoro, a eufonia, o ritmo e a métrica; (2) as unidades de significado que determinam a estrutura lingüística formal da obra literária; (3) a imagem e a metáfora; (4) o "mundo" específico da poesia no símbolo e nos sistemas de símbolos que chamamos de "mito" poético; (5) os métodos de análise aplicáveis a obras de arte individuais; (6) a natureza dos gêneros literários; (7) a avaliação da obra, problema central da crítica literária, que retorna à idéia da evolução da literatura; e, por fim, (8) a natureza da história literária e a possibilidade de uma história interna da literatura, ambas necessariamente imbricadas como história de uma arte; se constituem como aspectos fundamentais para a concepção de um paradigma para os estudos do poema, ou criação de um método de determinação e análise da obra, de forma a se poder aferir ou emitir qualquer juízo crítico sobre a mesma. 
Reiterando o posicionamento de Aquino Corrêa (1985 b, v. I, tomo II: 18), o qual considera que, à luz da crítica, distinguem-se, na obra literária, duas entidades: a forma e a matéria ou fundo, nas quais resplandecem duas belezas: a beleza da forma e a beleza da matéria, consideramos que os oito estratos da obra de arte, citados por Wellek e Warren (2006), orientam todo um procedimento de tradução da obra e a racionalização de princípios que constituem o processo empírico da crítica literária.

A princípio, a forma implica em que, sendo a obra literária uma estrutura elaborada a partir de uma série de sons da qual surge o significado, a métrica é um tema que interessa, à medida que pode suscitar o levantamento de novos espécimes métricos, e estender tais estudos às novas técnicas de produção da poesia contemporânea. E, a matéria poética implica em formas particulares de elaboração da linguagem simbólica da literatura, quer seja, a língua literária.

Para Aquino Corrêa, "sem esmero da linguagem não pode haver beleza literária" (CORRÊA, 1985 b: 19), claro que este argumento está enraizado nos estudos da Retórica, que, enquanto disciplina específica, é o primeiro testemunho, na tradição ocidental, de uma reflexão sobre a linguagem.

Simpáticos ao fato de se considerar que com a disciplina "Retórica" se originam, na tradição ocidental, todas as reflexões sobre a linguagem, somos tentados a recontar a lenda que deu origem a esta hipótese, para, a partir dela, entendermos a obra literária escrita como uma "estrutura de normas, realizada apenas parcialmente na experiência efetiva de seus muitos leitores" (WELLEK e WARREN, 2003: 192).

Proibidos de falar, os cidadãos de Siracusa, na Sicília, no século $V$ a.C., tomaram consciência da importância da palavra. Daí, os sicilianos teriam criado a Retórica para estudar a linguagem, não na qualidade de "língua", enquanto "sistema" através do qual se aprende uma língua estrangeira, mas na qualidade de "discurso", forma utilizada pelo cidadão para exteriorizar suas idéias. A eloqüência, neste caso, tornou-se uma arma necessária; daí que alguém considerou possível "ensinar a fala", e a disciplina denominada 'Retórica' traduziu como nunca, uma "técnica" que permite a quem a possua, convencer o interlocutor.

$\mathrm{Na}$ época de Aristóteles, a Retórica já se constitui como "um corpo de saberes, categorias e regras", das quais poucas são de domínio lingüístico específico, e muitas 
são de domínio discursivo, tais como o assunto, os argumentos, as técnicas de persuasão, o arranjo discursivo, a organização propositiva do texto, a memória, etc.

$\mathrm{Na}$ verdade, mediante a evolução das reflexões sobre a linguagem, a Retórica viu-se reduzida à arte do discurso, muitas vezes preocupada com as "figuras de linguagem", traduzidas como "desvios" ou modificações do que é considerado "normal" numa estrutura lingüística. Porém, a Retórica é a disciplina que mais significativamente, fornece fundamentos teóricos para o trabalho de elaboração da linguagem com propósitos estilísticos.

Nos estudos lingüísticos, nos últimos anos do século XIX e nos primeiros do século $X X$, há um interesse renovado em relação às "figuras", mas esta renovação origina-se na Lingüística, e realiza-se através da confluência de conceitos pertencentes a disciplinas como a própria Lingüística, a Análise do Discurso e a Estilística.

Teoricamente, esta afirmação implica na consideração feita por Wellek e Warren (2003: 226) de que a língua é o material do artista literário, e que toda obra literária é uma seleção arbitrária, extraída de determinada língua, no caso em que tratamos, a língua literária.

Para dar sustentação a este princípio, os críticos se apóiam nos argumentos de F.W.Bateson ${ }^{77}$, de que a literatura é uma parte da história geral da língua e que dela depende completamente, visto que

a marca de uma época em um poema não deve ser atribuída ao poeta, mas à língua. A história real da poesia é a história das mudanças do tipo de linguagem em que sucessivos poemas foram escritos. E são essas mudanças da língua apenas que se devem à pressão das tendências sociais e intelectuais (In: WELLEK e WARREN, 2003: 226).

Evidentemente, concordamos com Wellek e Warren (2003), em relação ao exagero do argumento de Batenson, que reduz a visão de poesia ao reflexo passivo das mudanças lingüísticas, isolando da história da literatura, a relação dialética entre

77 Frederic Wilse Bateson (1901 - 1978): crítico e historiador literário, autor de English Poetry and English Language, em que argumenta que a literatura é uma parte da história geral da língua e dela depende completamente. (BATESON, F.W. English Poetry and English Language, Oxford, 1934, p. Vi. (In: WELLEK e WARREN, p. 226). 
língua e literatura ocorrida através da leitura crítica e teórica, alegando que a história se ocupa de fatos da obra, e a crítica, de idéias, de opiniões e crenças. Porém, é este argumento, de que a marca de uma época em um poema é atribuída à língua, que nos serve de mote para sustentar a nossa consideração inicial de que o poema não muda com o tempo, o que muda é o seu funcionamento crítico, no interior do sistema literário, observado através de uma perspectiva metodológica que articula três tipos de leitura: a leitura histórica, a crítica e a teórica.

Aliado a este argumento de Bateson (1934), a favor da íntima dependência da história da poesia e da história lingüística, está o argumento de Karl Vossler ${ }^{78}$, segundo o qual, "a história literária de certos períodos ganharia com uma análise do meio lingüístico, pelo menos tanto quanto ganha com as costumeiras análises de tendências políticas, sociais e religiosas (...)", e acrescenta que especialmente em períodos e países onde muitas convenções lingüísticas lutam por domínio, os usos, posturas e compromissos de um poeta, além de se traduzirem como "aspectos inerentes a um estilo em particular, também se tornam importantes para a crítica literária porque implicam no desenvolvimento do sistema lingüístico e também na compreensão da própria arte do poeta e das suas implicações culturais", na história literária (In: WELLEK e WARREN, 2003: 227).

Estes dois argumentos servem-nos para, teoricamente, sustentar esta relação dialógica entre língua e literatura, e explicar a nossa travessia de análise crítica da poesia do final do século XIX para as primeiras décadas do século XX, buscando, na Estilística, os posicionamentos clássicos que explicam esta relação dialógica e esta travessia.

Retomamos as últimas décadas do século XIX, e vemos que a Estilística estava inteiramente contida na Retórica, e que no início do século XX, ela se traduziria numa estilística da fala e da língua alicerçada na obra de dois grandes pensadores: o suíço Charles Bally, na sua obra Tratado de Estilística Francesa (1951), e o alemão Karl Vossler, através das obras Positivismo e Idealismo na Linguagem (1923) e A linguagem como criação e evolução (1929).

A Estilística de Bally, assentada em princípios lingüísticos saussureanos, leva em conta o caráter social e coletivo da língua e o caráter individual da fala; já a língua,

${ }^{78}$ Karl Vossler (1872-1949), lingüista alemão que juntamente com Charles Bally deram impulso aos estudos de estilística literária, no início do século XX. 
traduzida como objeto da Lingüística, é um sistema de signos; e o signo é formado de duas partes, ambas psíquicas: uma perceptível, o significante, e outra inteligível, o significado.

A teoria de Bally acrescenta aos conceitos de Saussure que o significado exprime não só o conceito, mas também a afetividade. Então, teríamos a Lingüística preocupada com a língua, enquanto sistema de signos intelectivos; e a Estilística preocupada com a língua, enquanto sistema de signos afetivos, motivados, portanto.

Ora, o que Bally constituiu foi uma Estilística da língua e não da fala, que procura investigar os recursos da língua e não do escritor. Dado o seu caráter positivista, Bally entende que, ao falar, o indivíduo não cria a linguagem, ele utiliza o código lingüístico que a comunidade (no caso, a literária) Ihe impôs.

Já a Estilística de Karl Vossler tem outro horizonte metodológico e ideológico. Ao positivismo de Bally opõe-se o idealismo de Vossler. A Estilística é de inspiração croceana $^{79}$, fundamentada na intuição. Para Croce, "a arte é sempre a expressão de uma intuição", a Estilística da fala não prescinde da Estilística da língua e nela se apóia.

Teoricamente, defendemos que os princípios de Bateson e Vossler criam o núcleo lingüístico e sustentam teoricamente a representação lingüística da poesia, como resultado de um tratado com marcas materiais de afetividade e intuição.

Muito a propósito, acrescentamos aos argumentos de Bateson e Vossler, citados por Wellek e Warren (2003), os princípios teóricos de Bakhtin (2000:215) e de Saraiva Lopes (1975:8) para assentar o nosso postulado sobre a relação íntima existente entre o estilo individual, os estilos que marcaram uma época, e todos os contextos socioculturais que envolvem o escritor, expressos através da língua como uma forma para direcionar o nosso trabalho, no sentido de perceber que os estudos literários são resultados de experiências humanas coletivas.

Bakhtin (2000: 215) nos faz notar que tanto o estilo individual dos atores sociais como o estilo característico do período ou da época, em que estes atores se registram, são unidades constituídas através de procedimentos particulares, empregados para dar

\footnotetext{
${ }^{79}$ Benedetto Croce (Itália, 1866-1952) - as idéias de Croce sobre a estética como ciência da expressão e da lingüística em geral provocaram um interesse imenso, na Itália e em toda a Europa. Pode-se dizer que a vida cultural italiana, a partir dos primeiros anos deste século, girou em torno de Benedetto Croce e de suas idéias, expressas nas obras Estética como ciência da expressão e Lingüística geral, 1902.
} 
forma e acabamento ao "herói e ao seu mundo", bem como de recursos exigidos por estes procedimentos, para dar forma, elaborar e adaptar esteticamente um material .

Saraiva e Lopes, nas reflexões preliminares da sua obra História da Literatura Portuguesa (1975), ressalta que

por muito que um estilo se individualize, ele nunca deixa de aludir à experiência humana coletiva, e que nenhuma obra literária se comunicaria se a maior parte das suas expressões não tivesse significados que já, até certo ponto, vêm do uso corrente da língua respectiva, em determinada fase da sua evolução (Op.cit. 1975: 8).

A fim de perceber a especificidade estilística de um texto, não prescindimos do estudo analítico, e, para tal, tomamos categorias emprestadas de várias teorias, elaboramos relações homólogas entre Retórica, Lingüística, Poética e Estilística com a "leitura".

Igualmente, fizemos "subdivisões" verticais das ciências da linguagem, como, por exemplo, a Poética, se ocupando do discurso literário; a Lingüística, do discurso lingüístico; a Estilística do discurso estilístico; e subdivisões "horizontais", cujo objeto é apenas um, a língua, porém, sempre referente a todos os tipos de discurso, concebemos a estilística do texto, do autor, da época; a Poética do texto, do autor, do leitor. $\mathrm{Na}$ verdade, procuramos considerar de que forma certas categorias individualizantes funcionam no interior de um sistema cada vez mais transversalizado e pluralizado, visto que é nesta direção que, atualmente, envereda grande número de pesquisas.

Assim, sob a bandeira dos estudos comparatistas, a obra literária apresenta, invariavelmente, uma forma autônoma, opcional, fruto da escolha e interesse do poeta no interior de um sistema lingüístico, marcado pela inumerabilidade das categorias existentes em um sistema, porém, a matéria que constitui esta forma resulta das "experiências sociais" do poeta, e ganham forma, e nela se pode reconhecer um estilo individual adequado à formação do escritor, em particular; ou a um estilo de época adequado às características de cada idioma; ou a um estilo de cada camada social; ou, por fim, a um estilo de cada época e de cada escola literária. 


\subsection{Língua literária: obediência a que norma}

Mediante o aparato teórico apresentado, fazemos outra consideração sistemática em relação à teoria e à crítica da poesia produzida em Mato Grosso: qualquer que seja a forma adotada pelo escritor, para elaborar a linguagem literária, ela não escapará à subordinação de uma "norma", que funciona como reguladora interna das inovações processadas no sistema.

Para o esclarecimento deste postulado, apropriamo-nos do juízo crítico de Benilde Justo Caniato, que em seus estudos apresentados na obra Percursos pela África e por Macau (2005) $)^{80}$, procura refletir, principalmente, sobre a valorização da língua como suporte de cultura literária, na medida em que os discursos são construídos como forma de expressão que assinalam a identidade dos espaços geográficos.

A este juízo crítico da pesquisadora de língua e literatura e também crítica literária, aliamos seus postulados teóricos sobre língua, fala, sistema e norma, expressos no artigo "Língua" (Dezembro de 2003), considerando que estes são basilares para o entendimento da língua enquanto suporte da cultura literária.

Sob a ótica de Caniato (2003), a linguagem é uma abstração que se concretiza através da língua, que é um sistema coletivo, virtual, abstrato, cuja manifestação concreta ocorre através da fala que é individual. Esta realização concreta, individual, denominada de fala, embora seja arbitrária por refletir uma opção do indivíduo, subordina-se a determinadas "normas" válidas para todos os usuários do sistema. Então, no interior do sistema, a fala traduz-se como realização concreta, em uma forma sistematizada de um processo de comunicação intersocial, simultaneamente individual e coletiva.

Esta homologia leva-nos a perceber que, no interior do sistema há várias normas, ou realizações coletivas do sistema, que consagram muitas possibilidades de realizações da língua, assumindo diferentes formas de relação. Daí, que uma língua admite várias normas ou "escolhas individuais" interativas, que se consagram em

${ }^{80}$ CANIATO, Benilde Justo. Percursos pela África e por Macau. Cotia, São Paulo: Ateliê Editorial, 2005. 
comunidades lingüísticas formadas por afinidade ou por imposição, ou os dois ao mesmo tempo.

Caniato (2003) explica que a língua não é um sistema unitário, é um "diassistema" formado por vários sistemas e sub-sistemas inter-relacionados entre si.

Se as normas - realizações coletivas da língua - produzem formas variadas, temos o esclarecimento do polimorfismo lingüístico característico de todas as línguas, decorrente de fatores geográficos, históricos, sociais e culturais, transpassados por fatores afetivos ou de afinidades.

A norma apresenta subsistemas ou formas resultantes de variações geográficas (diatópicas), sociológicas (diastráticas) e contextuais (diafásicas).

Os subsistemas ou formas resultantes de variações geográficas são intercontinentais, daí temos a língua portuguesa característica de Portugal, do Brasil, de Angola; e inter-regionais, daí, temos os sub-sistemas marcados por regionalismos caracterizadores das diversas regiões do país.

Os subsistemas ou formas resultantes de variações sociológicas (diastráticas) são variações internas da mesma comunidade lingüística marcada por aspectos que traduzem afetividade ou afinidade entre os falantes, deparando-nos com um subsistema lingüístico caracterizado pelos registros dos níveis da fala, daí resultam a língua culta, a coloquial, a popular, as gírias, os jargões, etc.

Os subsistemas ou formas resultantes de variações contextuais (diafásicas) traduzem as normas de interações coletivas do sistema lingüístico, daí, temos as normas referentes à oralidade, de ordem mais afetiva, que estruturam a língua falada; as normas referentes à sistematização, à organicidade de ordem mais intelectual do sistema, próprio da língua escrita; as normas referentes à elaboração simultânea das interações coletivas, da sistematização e da expressão individual, que traduzem a língua literária.

É neste contexto, marcadamente conceitual, em que as normas referentes à sistematização e à organicidade do sistema próprio da língua escrita, mais as normas referentes à elaboração simultânea das interações coletivas, da sistematização e da expressão individual, que traduzem a língua literária, é que identificamos o espaço ocupado por Aquino Corrêa, no sistema da literatura produzida em Mato Grosso. 
No contexto da elaboração da escrita poética de Aquino Corrêa acentuam-se as formas clássicas, formando o conjunto de suas obras e a consciência crítica sobre a leitura dos ditos antigos (REBELO, 1980:117) ${ }^{81}$, para quem a qualidade literária está sujeita às normas de convenções métricas, à beleza formal, e à beleza do conteúdo. $A$ poesia, vista sob este ângulo, reflete uma espécie de valor social de opção subjetiva e uma representação muito mais da figura do escritor do que mesmo do valor artístico da escola literária a que ela se filia, e se representa no interior do sistema literário.

A divisão que Aquino Corrêa propõe à publicação de Odes (1985 a) reitera o caráter remissivo às formas clássicas da literatura: Psalmódias, Melodias e Rapsódias estão assentadas no âmbito das contribuições trazidas pela leitura dos clássicos, atualizadas em um processo contínuo de ajustamento das formas às realidades social e cultural dos escritos, e identificadas em um estilo literário que apresenta pouca variedade.

A terceira parte da obra denominada Rapsódias está subdividida em duas partes, e sua significação emblemática se dá a partir dos próprios títulos: Musa em botão e Musa em Ócio, ambas reúnem as composições poéticas datadas entre os anos de 1899 e 1916, e delineiam o percurso inicial do poeta situado no espaço das referências de leitura de obras da literatura clássica. Esta parte da obra de Aquino Corrêa, é denominada, pelo próprio poeta de, Versões e Diversões, subtítulo que identifica uma espécie de passeio que o escritor faz pelo mundo da tradução de versos escritos em língua latina, referenciada em Virgílio e Horácio, em italiano e em espanhol, e as tentativas do poeta de fazer versos em língua estrangeira.

Os posicionamentos críticos referentes à tradução e aos versos escritos em língua estrangeira, identificados em Aquino Corrêa, quer sejam vistos de uma perspectiva histórica, quer sejam vistos a partir do discurso crítico do escritor, levam em consideração a classificação de textos e traduções literárias, assentados mais no conceito de literariedade, do formalismo russo, elaborado por Roman Jakobson $(1919)^{82}$, do que no sentido de "literatura".

\footnotetext{
${ }^{81}$ REBELO, Luís de Sousa. A tradição clássica na literatura portuguesa. Lisboa: Livros Horizontes, 1980.

${ }^{82}$ Fonte: JAKOBSON, Roman. Linguistic and poetcs. In Select writings. In: CARVALHAL, Tânia Franco (Coord.). Culturas, contextos e discursos: limiares críticos do comparatismo. Porto Alegre: Ed.

Universidade/UFRS, 1999.
} 
A constatação desta visão crítica de Aquino Corrêa, em relação à tradução e aos versos escritos em língua estrangeira, torna-nos muito mais interessados em clarear o porquê de os formalistas russos considerarem a literariedade como o objeto da ciência literária, e não a literatura conforme alega a tradição crítica, e a partir daí, buscamos na conceituação desta palavra tanto o sentido como o processo que a transformou em objeto dos estudos literários.

Para atender a este propósito, a "literariedade" é tomada conforme o sentido proposto por Rodrigues $(1999)^{83}$, no ensaio crítico "Os limiares da crítica da tradução na pós-modernidade", que a entende

em termos de "desautomatização" da linguagem pela utilização de recursos formais e lingüísticos que situam a linguagem do texto literário em primeiro plano, numa oposição frontal à linguagem comum, ordinária, do texto não-literário. Esses desvios que colocam a linguagem em foco são bastante evidentes, por exemplo, na poesia, e são observados principalmente no metro, na rima, e em outros recursos de uso do som e da repetição (RODRIGUES, 1999: 122).

Claro que o entendimento de "literariedade" sob este ângulo funciona como uma classificação com fins operacionais, que possibilita estabelecer a distinção entre o texto literário e o não-literário, mediante aspectos que se prendem à textualidade. Neste caso, tanto o sentido como o processo de "desautomatização" da linguagem literária levam-nos a entender, a partir da análise crítica do texto literário, o funcionamento de determinadas normas de realização coletiva da língua literária.

Esta relação, que se afigura tão complexa, nada mais traduz, perseguindo ainda o juízo crítico de Rodrigues (Op.Cit : 123) do que a ligação íntima entre tradução literária, teoria literária e a literatura comparada, visto que

no processo de decodificação do texto literário para a posterior elaboração do texto traduzido, há a leitura em profundidade do texto-fonte, com a exigência de análise crítica de suas especificidades literárias textuais as quais serão transpostas, pelo tradutor, quando da reescritura do texto original. Para que 0

${ }^{83}$ Fonte: RODRIGUES, Sara Viola. Os limiares da crítica da tradução na pós-modernidade. In: CARVALHAL, Tânia Franco (Coord.). Culturas, contextos e discursos: limiares críticos do comparatismo. Porto Alegre: Ed. Universidade/UFRS, 1999. 
tradutor possa realizar essa reescritura produzindo um texto equivalente em termos de significância ao texto original, ele deve valer-se de muitas das ferramentas da teoria literária" (Op. Cit. : 122).

A princípio, pensamos uma identidade discursiva de Aquino Corrêa correlacionada à forma como este fazia os seus poemas, preservando os valores que marcaram a sua formação intelectual. Na esfera da crítica literária, ativemo-nos a determinados posicionamentos críticos do escritor que nos aproximam de uma literatura que reflete as mudanças sociais da humanidade. Nesta esfera, percebemos a confluência da arte e da crítica literárias, ambas sujeitas à lei do progresso, sem desconsiderar as inúmeras influências que acentuam o nível de sensibilidade humana nas transformações, resultando, deste processo, o aparecimento do leitor, adquirindo uma outra dimensão: a de crítico.

Nas reflexões propostas por Cárcamo ${ }^{84}$, em relação às influências das leituras críticas referentes ao passado, na literatura, o leitor é instalado na sua atualidade e exerce a função de crítico, cujo trabalho fundamental é perceber tais influências e voltar-se aos contatos de qualquer época, porém, com a sensibilidade moderna.

No ensaio "Poética Comparada", publicado na revista da ABRALIC Cânones \& Contextos $^{85}$ (1998:1041), Lúcia Sá Rebello, utiliza-se dos princípios teóricos definidos por Brunel, Pichois e Rousseau, em O que é literatura Comparada ${ }^{86}$, segundo os quais, existe uma poética comparada que não é a comparação das artes, mas antes a das práticas literárias, da escritura ${ }^{87}$, que procuram refletir 0 campo normativo da elaboração textual do objeto estético, perseguindo a idéia de que

para se estudar a técnica de fabricação, do ponto de vista dos autores, deve-se, primeiramente, fazer a descrição das formas de composição - líricas, dramáticas, narrativas - ou de elocução -

${ }^{84}$ CÁRCAMO, Sílvia Inês. A re-definição do cânone literário: Azorín e a crítica literária na Espanha de princípio do século. Cânones \& contextos: 5ํㅡㄹ Congresso da ABRALIC, 30 de julho a 02 de agosto, anais, Vol.3, p.713-717, Rio de Janeiro:1998.

${ }^{85}$ Em Associação Brasileira de Literatura Comparada - Congresso. Cânones \& Contextos: 5ํㅡㄴ Congresso da ABRALIC, 30 de julho a 02 de agosto, anais, Vol. 3, p.1041-1045, Rio de Janeiro:1998.

${ }^{86}$ BRUNEL, P. PICHOIS, C. e ROUSSEAU, aM. Que é literatura Comparada. São Paulo: Perspectiva, 1990.

${ }^{87}$ Idem, ibidem, p. 125. 
vocabulário, clichês, imagens, tons. Depois, analisar as categorias individuais de transposição literária, isto é, com que palavras se pode transpor o real, o tempo, o espaço, o mais íntimo do seu eu e a vida dos outros. Por fim, deve-se levar em conta as estruturas coletivas e a ligação entre o literário e a sociedade (REBELLO, 1998: 1041).

Sob este ponto de vista, fazemos sobressair os postulados críticos de Aquino Corrêa (1985), que preceituam uma literatura claramente explicitada pelo comportamento crítico-formativo do poeta, situado na sua atualidade social e no interior da confluência dos gestos criativo e teórico.

O gesto criativo se assenta nas margens dos acontecimentos sociais da vida do artista, através de um processo de elaboração que não foge das inspirações e se traduzem em formas particulares de ver, sentir e transformar o acontecimento social. Nesta visão, o poeta é, por excelência, um ser social , que vive e sonha no seio de uma sociedade.

O gesto teórico se assenta nas fronteiras das normas que assinalam as variações das formas no interior de um sistema. As variações apontam para a filiação genérica do escritor e são concretizadas pela tensão entre as formas existentes e os recursos utilizados pelo artista para ver, sentir e transformar em símbolos motivados que registram tanto os acontecimentos sociais como o comportamento discursivo do autor, no interior do seu ambiente sóciocultural.

Esta relação de convergência do gesto criativo e do gesto teórico é traduzida no discurso de Aquino Corrêa, em posicionamentos que exigem, simultaneamente, a presença do escritor e do leitor críticos, em um plano que se estende no horizonte de pesquisas ancorado na curiosidade teórica.

Certo é que, diante de todos as distinções que fizemos entre gesto criativo e gesto teórico, liberdade de expressão pessoal e organização textual, percepção do texto literário como forma de realização da matéria poética, conforme orienta Antonio Candido, ou como "processo" e "instrumento didático", nos termos referidos por Wladimir Dias-Pino, - defrontamo-nos com "reformulações" (WELLEK e WARREN, 2003: 22) expressas através de termos bem antigos, como: criação, inspiração, estrutura textual, poesia, poema, matéria, forma, etc. 
Cada uma destas reformulações indica termos que descrevem um aspecto da obra literária, um traço característico das suas direções semânticas e que se constituem como dados verificáveis, que subsidiam os estudos críticos sobre a literatura e a língua literária.

Somente a percepção crítico-analítica destas reformulações identificam grandes reformuladores e criadores da língua, que, rompendo com uma norma, de forma consciente ou não, realizam as várias possibilidades do sistema em seu mais alto grau - a literatura.

Assim, retomando o juízo crítico de Caniato (2003), de que "não aprendemos uma língua, mas aprendemos a criar uma língua, ou seja, aprendemos as normas de uma língua", fazemos a seguinte afirmação: visto que o conceito que adotamos de norma implica maior liberdade de expressão na escolha do vocabulário, do léxico, do uso gramatical, da construção sintática e do arranjo textual, procuramos distinguir, primeiramente, as particularidades que alimentam as literaturas da comunidade formada pelos oito países de língua portuguesa: na América do Sul, o Brasil; na Europa, Portugal; na África, Angola, Moçambique, São Tomé e Príncipe, Cabo Verde, e Guiné - Bissau; e na Ásia, o Timor Leste. Em segundo lugar, entendemos o gesto criativo e o gesto teórico de grandes reformuladores e criadores da língua de expressão literária, e, por último, entendemos o esforço de pesquisadores que procuram, através de estudos analíticos de pormenores textuais, dar corpo crítico-teórico a determinadas formas muito particulares de expressão que garantem a individualidade destes países, concretizada através da sua língua e da sua literatura. 


\section{CONSIDERAÇÕES FINAIS}

Um texto quer que alguém o ajude a funcionar.

(Umberto Eco, 1993) 
Umberto Eco, ao tratar sobre a questão do leitor, no terceiro capítulo da sua obra Leitura do texto literário ${ }^{88}(1993)$, apresenta-nos o texto literário como uma estrutura incompleta, por duas razões: primeiro, a manifestação lingüística representa uma cadeia de artifícios expressivos criados pelo seu autor, e, portanto, não se refere somente à materialidade dos objetos e situações lingüisticamente expressas através da estrutura textual; segundo, um texto exige do leitor um trabalho inferencial que promova a atualização da mensagem através da interpretação. Evidente que este modo de entendimento do texto literário requer movimentos cooperativos por parte do leitor, o que, sistematicamente, pressupõe domínio de competência tanto gramatical como extralingüística.

Nos estudos que realizamos sobre os princípios da teoria da crítica literária da poesia produzida em Mato Grosso, a partir de Aquino Corrêa, assentados no binômio forma/matéria poéticas, entendemos o texto literário entretecido de espaços em branco, de interstícios a serem preenchidos, porque, segundo Eco ( 1993:55), "o texto é um mecanismo preguiçoso que vive da mais-valia de sentido que o destinatário the introduz", e, em se tratando do texto literário, há uma função estética em que "um texto pretende deixar ao leitor a iniciativa interpretativa, ainda que habitualmente deseje ser interpretado com uma margem suficiente de univocidade" (Ibidem).

Assim, nestas abordagens que colocam a língua literária no foco do que é defendido nesta tese - discutir o belo apenas sob o prisma literário, através da expressão da beleza literária assentada na beleza da forma e da matéria poéticas - em que se constitui através da tríade forma/matéria/língua, traçamos os princípios fundamentais da crítica da poesia no Mato Grosso, procurando dar consistência à nossa hipótese, considerando as abordagens críticas expressas nos textos de pesquisadores da literatura, em Mato Grosso.

A opção por textos críticos assenta-se na consideração de que eles representam os resultados de pesquisas que mostram que "uma obra de arte literária não é um objeto simples, mas, antes, uma organização altamente complexa, de caráter estratificado, com múltiplos significados e relações" (WELLEK e WARREN, 2003: 22).

${ }^{88}$ ECO, Umberto. Leitura do texto literário. Título original: Lector in fábula. Trad. Mário Brito. 2 ed. Lisboa: Editorial Presença, 1993. 
No decorrer da apresentação dos nossos estudos, usamos fartamente a terminologia "forma" e "matéria", sempre procurando destituir estas palavras de um caráter partitivo e reducionista, que faz pensar que qualquer aspecto da obra de arte seja uma parte, apenas uma "forma" que foi isolada, retirada da totalidade orgânica da obra, tornando-a "defeituosa"; ou apenas um aspecto da "matéria" que, intuitivamente, foi percebida, uma "iluminação".

É claro que são estes modos particulares de ver a obra literária que demonstram a sua totalidade, o funcionamento interno e interativo das partes para que a "arte" ou "literatura", ela possa ser interpretada e compreendida.

É a visão interativa e o caráter dialógico das formas de elaboração da matéria poética que interessam à crítica literária. A terminologia obriga-nos a ver a obra na sua totalidade. São aspectos que mostram a intimidade e a complexidade de um todo interativo da obra de arte no seu modo de existência, no seu sistema de estratos e no seu funcionamento no interior do sistema literário.

Teoricamente apoiados em Umberto Eco, que em sua obra As formas do conteúdo (2001), no capítulo 4, coloca que as características do uso estético de uma língua são a "ambigüidade e a auto-reflexividade" - a ambigüidade porque permite que, através do leitor, a mensagem se torne inventiva em relação às possibilidades comumente reconhecidas ao código, e torna-se auto-reflexiva porque comunica igualmente sua organização física. Face a esta possibilidade de inventividade, reconhecida no interior do código em que ela foi elaborada, afirmamos a indissociabilidade da forma e da matéria poéticas, na elaboração e avaliação do objeto estético.

Considerando estas duas características, é possível asseverar que, na arte, forma e conteúdo são inseparáveis, porém, isso não deve significar que não seja possível distinguir os dois planos: o plano da forma de conteúdo e o plano da forma de expressão, pois tudo quanto de específico ocorre no nível de cada um deles, ao contrário, quer dizer que as mutações nos dois níveis são sempre uma em função da outra.

Segundo Umberto Eco (2001: 110), "em toda discussão estética, sempre se corre o risco de manter as afirmações em um nível puramente teórico". Mediante o 
aparato teórico que apresentamos, procuramos, em nossas considerações finais, fazer a verificação prática, utilizando-nos de textos, cujas mensagens estéticas já foram elaboradas, e regras internas de organização do próprio código literário.

Os textos "Confluências, divergências e singularidades", do pesquisador Isaac de Almeida Ramos ${ }^{89}$; "Convergências poéticas na perspectiva comparatista", da pesquisadora Elizete Dall' Comune Hunhoff ${ }^{90}$; "Wladimir Dias Pino e o livro de artista", do pesquisador Sérgio Dalate ${ }^{91}$; "Deslocação: fixo e móvel - tradição e transgressão", da pesquisadora Nancy Lopes Yung ${ }^{92}$ e "Criador e criatura: um estudo comparativo entre Carlos Drummond de Andrade e Miguel Torga", do pesquisador Genivaldo Rodrigues Sobrinho ${ }^{93}$, publicados no livro Ensaios de Literatura Comparada: PortugalBrasil-Angola-Cabo Verde ${ }^{94}$, são ilustrativos na composição deste cenário atual das reflexões sobre teoria e crítica literárias estruturadas numa linguagem literária capaz de expressar as várias possibilidades de que a língua tem de gerar e normatizar sua própria representação estética.

A obra literária é feita de palavras, de frases. As frases pertencem a registros diferentes da fala, registros que se apóiam em duas grandes dicotomias: o enunciado, exclusivamente verbal e a enunciação, que consiste no ato de produzir o enunciado, compreendendo também o enunciado numa situação que apresenta elementos nãoverbais: o emissor, o receptor e o contexto (CANIATO, 2003) ${ }^{95}$.

Perseguindo este juízo crítico de Caniato(2003), percebemos que os textos demonstrativos dos resultados das pesquisas privilegiam determinados aspectos da linguagem dos poemas, que traduzem formas particulares de expressão individual do poeta, através da língua literária:

${ }^{89}$ Professor da UNEMAT - Campus de Alto Araguaia.

${ }^{90}$ Professora da UNEMAT - Campus de Tangará da Serra.

${ }^{91}$ Professor da Universidade Federal do Mato Grosso - Cuiabá.

92 Professora da UNEMAT - Campus de Cáceres.

${ }_{93}$ Professor da UNEMAT - Campus de Sinop.

94 Ensaios de Literatura Comparada: Portugal-Brasil-Angola-Cabo Verde. Agnaldo Rodrigues Sobrinho e Isaac Newton Ramos (Org) - Cáceres, MT: UNEMAT Editora, 2004.

${ }_{95}$ Esta idéia vem sendo desenvolvida por Benilde Justo Caniato em seus estudos recentes sobre a interação língua/literatura. Conferir: CANIATO, Benilde Justo. Língua literária (breves considerações): o português como língua literária e o português do Brasil e o português de Portugal, p. 2. (em fase de elaboração). 
A língua literária se caracteriza hoje pela busca do individual da expressão, em que tal ato se reveste de formas lingüísticas estabelecidas pela gramática, mas impregnada de expressividade individual. Se não há esquemas preconcebidos, há maiores possibilidades de escolha na multiplicidade de aspectos lingüísticos, que podem exprimir a mesma idéia. São variantes estilísticas. Daí poder dizer que a língua literária seria, na essência, uma estilização da língua usual, da língua corrente (CANIATO, 2003, p. 2).

Assim, Ramos (Op. Cit. p.39) sugere uma experiência intra e intertextual entre Fernando Pessoa e Manoel de Barros, em que os versos traduzem formas de expressão do equilíbrio entre sensibilidade e intelectualidade, conforme os termos com que Valéry (1991) ${ }^{96}$ define o verso "equilíbrio maravilhoso e sensibilíssimo entre a força sensível e a intelectual da linguagem"; Hunhoff (Op. Cit. p.106) defende uma linguagem poética que cria formas mescladas que traduzem simultaneamente a poesia e o lúdico, sendo que o poeta cria "modelos" em que a poesia e a linguagem de expressão do lúdico cumprem uma função simbólica, levando o leitor a recriar significados e desenvolver atitudes prazerosas de sentidos polissêmicos - "isso porque a poesia traz para o leitor inúmeras formas de exercitar capacidades cognitivas de modo prazeroso"; Dalate (Op. Cit. p.119) intensifica a relação entre a palavra e o seu teor simbólico, gerando formas de expressão que traduzem simultaneamente a experiência concreta da palavra e do papel e o espírito de "síntese subjacente à sintaxe gramatical e à sintaxe simbólica"; Yung (Op. Cit. p.136) traduz uma ruptura com o tradicional através da transgressão de uma forma fixa, a balada, utilizando-se da dimensão física do papel e das linhas para dispor os versos do poema na página; Sobrinho (Op. Cit. p.177) acentua as formas poéticas que constituem a poesia a partir de um momento individual, dele se desprendendo quando na palavra passa a pertencer "ao mundo das aparências", do símbolo motivado.

E, por último, consideramos que todos os textos literários marcam-se por uma linguagem em transformação, em renovação, realizada através da língua literária que, atualmente, se caracteriza pela busca do individual da expressão artística. Temos pesquisadores, temos institutos de pesquisas, temos incentivos de órgãos

\footnotetext{
${ }^{96}$ VALÉRY, Paul. Variedades. Trad. Maíza Martins de Siqueira. São Paulo: lluminuras, 1991.
} 
fomentadores de pesquisa, temos equipes de trabalho, temos audácia de colocar problemas tradicionais sob uma nova ótica, e, por último, não temos medo de arriscar uma hipótese para defender a teoria de uma crítica consciente para a poesia produzida no Mato Grosso.

O reflexo desta consciência crítica pôde ser sentido durante a realização do $X$ Congresso Internacional da ABRALIC - 2006, realizado na UERJ, no Rio de Janeiro, nos dias 30 de julho a 04 de agosto de 2006. Através do Simpósio "Na audiência do tempo: regionalismo e intertextualidade na Literatura de Mato Grosso", ficaram registrados o empenho e o comprometimento dos pesquisadores em divulgar os trabalhos críticos da literatura produzida em Mato Grosso.

A ênfase foi dada aos aspectos singulares ou diferenciadores que, no texto literário, refletem o discurso dos escritores mato-grossenses, indicando fatores que medeiam, interferem e individualizam os poetas nessa rede intrincada de trocas e transferências literárias, no interior do macrossistema das literaturas de língua portuguesa.

Em duas mesas, as comunicações trataram especificamente da poesia em Mato Grosso. Na mesa I - "Poesia: território de diálogo", coordenada pelo Professor Mestre Isaac Newton de Almeida Ramos ${ }^{97}$, as comunicações apresentadas priorizaram questões que referenciavam a forma poética, valorizando os elementos expressivos ligados à língua literária. Inclusive, participou como convidado especial da mesa, o poeta mato-grossense, residente no Rio de Janeiro, Wladimir Dias Pino, considerado como um dos precursores do Modernismo em Mato Grosso.

Ao ser questionado sobre o que leva um escritor a ganhar um espaço no cenário das belas letras nacionais, o escritor respondeu "- O inusitado! Sim... só conseguem um lugar ao sol das letras aqueles que conseguem criar algo inusitado, algo que interfira no sistema como 'algo novo', porém, sustentável.."98.

A esta fala de Wladimir Dias Pino, acrescentamos a consideração de que, conforme afirma Aquino Corrêa, "O verdadeiro poeta não pode ser um desorientado; é,

\footnotetext{
${ }_{98}^{97}$ Prof. Msc. de Literatura, da Universidade do Estado de Mato Grosso, campus de Alto Araguaia.

${ }^{98}$ Fonte: PINO, Wladimir Dias. Entrevista coletiva concedida aos participantes do Simpósio "Na audiência do tempo: regionalismo e intertextualidade na Literatura de Mato Grosso", no X Congresso Internacional ABRALIC - 2006, realizado na UERJ, no Rio de Janeiro, no dia 02 de agosto de 2006.
} 
pelo contrário, dos mais bem orientados entre os homens" (CORRÊA, 1985 a, v. I, t. I: 29).

Na mesa II - "Poesia: território de diálogo", coordenada pela Professora Mestre Marinei de Almeida ${ }^{99}$, participamos com a comunicação "Aquino Corrêa: uma leitura possível", a qual apresentou a análise crítica da edição especial das obras de Aquino Corrêa, comemorativa do centenário de nascimento do escritor mato-grossense, editada em 1985. Nesta comunicação estabelecemos as relações dialógicas entre teoria e prática literárias, através do deslocamento de Aquino Corrêa do espaço 'do poeta', para o espaço 'do teórico', preocupado em discutir o "belo" apenas sob o prisma literário, assentado na beleza da forma e da matéria poéticas.

Dentre os trabalhos apresentados, privilegiamos somente aqueles que trataram temas relacionados à poesia, em especial, à matéria e à forma poéticas, interpretadas sob os mais diversos ângulos.

Genivaldo Rodrigues Sobrinho ${ }^{100}$ apresentou a comunicação "Um breve estudo sobre Lobivar de Matos", voltada para a análise da produção poética deste poeta que representa a geração da Primeira Guerra Mundial. Neste sentido, vale lembrar o comentário de Rubens de Mendonça, estudioso da literatura de Mato Grosso, para quem, na região, a Guerra foi, sem dúvida, um ponto visível entre duas gerações: uma anterior, que insistia nas marcas da estética parnasiana, e a contemporânea de Lobivar de Matos, que vai trazer os ideais estéticos postulados pelo Modernismo. Essa afirmativa se verifica em Areotorare (1935) e Sarobá (1936). Essas obras receberam uma crítica positiva de Manuel Bandeira que afirmou terem "um forte sabor regional os poemas do poeta mato-grossense Lobivar de Matos" (In: Mendonça, 2005); e também da pesquisadora da literatura mato-grossense, Hilda Magalhães (2001), que acentuou: "os dois únicos livros escritos por Lobivar de Matos exploram as margens do submundo, denunciando, com fortes matizes naturalistas, o lado mais execrável da sociedade". Nesse sentido, compreendemos, à luz de seus versos, uma matéria poética que

\footnotetext{
${ }^{99}$ Professora da UNEMAT, do campus de Pontes e Lacerda.

${ }^{100}$ Professor do Departamento de Letras da Universidade do Estado de Mato Grosso, (Unemat/Campus de Sinop).
} 
representa os espaços marginais da sociedade mato-grossense da primeira metade do século XX.

Isaac Newton Almeida Ramos apresentou a comunicação "As poéticas de Wlademir Dias Pino e Silva Freire", enfocando poéticas de vanguarda, e destacando os poetas Wlademir Dias Pino e Silva Freire como inovadores da linguagem literária e legítimos representantes do movimento concretista no Estado de Mato Grosso.

Na mesa-redonda 5 - "Poesia: território de diálogo" - coordenada por Marinei Almeida Lima ${ }^{101}$, a pesquisadora Marta Helena Cocco ${ }^{102}$ apresentou a comunicação "A linguagem como resistência no fazer poético de Lucinda Persona", a qual apresentou o estudo que investiga, por meio de pesquisa biobibliográfica, a concepção de arte engendrada pelo eu-lírico, em poemas metalingüísticos publicados nos livros Ser cotidiano e Sopa escaldante.Teoricamente apoiada em Gilles Deleuze e Félix Guatari, a respeito das sensações que se conservam na arte, e, por Alfredo Bosi, acerca das tendências poéticas contemporâneas que fazem da arte um ato de resistência, os primeiros afirmam que a arte luta com o caos para fazer surgir, através dela, uma visão que o ilumina; e, para Bosi, a poesia é um discurso que persiste, apesar do meio hostil. Analisada sob essas concepções, a linguagem, nos poemas de Persona, constitui-se numa forma que não se presta apenas a comunicar algo, a repetir o que já foi dito, mas, independentemente da importância dos eventos, a linguagem reflete uma atitude de resistência que se dá, em vez do protesto e do grito, pelo recolhimento, e, na solidão.

Lucinda Nogueira Persona ${ }^{103}$ apresentou a comunicação "Fidelidade ao comum" a qual ressalta uma forma constituída no aspecto temático inovador da sua poética de gosto pelo comum, "vertida no paradoxal gosto e desgosto pelo corriqueiro". A escrita poética da escritora compõe-se de quatro livros: Por imenso gosto (1995), Ser cotidiano (1998), Sopa escaldante (2001), e Leito de acaso (2004). Segundo a escritora, em suas obras, fragmentos críticos de poetas e escritores são resgatados e cotejados entre si, procurando manter uma acentuada fidelidade ao comum que lhe serve de substrato.

\footnotetext{
101 Professora no Departamento de Letras da Universidade do Estado de Mato Grosso (Unemat/Campus de Pontes e Lacerda).

${ }^{102}$ Escritora e professora de Literatura Brasileira no Centro Universitário de Várzea Grande/MT (Univag), Mestranda em Estudos da Linguagem, pela Universidade Federal de Mato Grosso.

${ }^{103}$ Escritora, Professora aposentada/UFMT, Professora em exercício na Universidade de Cuiabá (UNIC), e Mestre em Histologia e Embriologia pela UFRJ. E-mail: Ipersona@terra.com.br
} 
A pesquisadora Marinei Almeida Lima apresentou a comunicação "Manoel de Barros e Eduardo White: entre vôos, pântanos e ilhas", em que propôs um enfoque dialógico que privilegia a intertextualidade, considerando os diferentes contextos histórico, político e literário em que se inserem, de um lado, no continente da América Latina, mais especificamente, do interior do Brasil, a atenção recairá sobre a obra $O$ Livro de Pré-coisas (1985), do poeta Manoel de Barros, reconhecido, atualmente, como um dos mais originais do país, e que, através de sua matéria prima - a linguagem -, cria e recria "mundos" fluídos e circulares, onde a vida e a morte fervilham no rastro animal e vegetal. De outro lado do oceano, em Moçambique, a obra Janela para o Oriente (1999), do poeta Eduardo White - "rebelde confesso e determinado" - lança mão de uma linguagem poética codificada, e trilha por um caminho novo na literatura de seu país, onde esta deixa de servir como instrumento pragmático a serviço do local e do momento e passa para uma esfera universal, como principal meio de inter-relações com outros países e com outras culturas.

A pesquisadora Renata Beatriz Brandespin Rolon ${ }^{104}$ apresentou a comunicação "Bernardo: um personagem mítico-pantaneiro", a qual apresenta um traço inovador da forma de expressão da prosa-poética de Manoel de Barros. O escritor cria, na obra Livro de Pré-Coisas, a figura de Bernardo da Mata, personagem misto de ficção e de vida real que simboliza uma espécie de totem pantaneiro. A forma com que é descrito nas obras de Barros, além de já ter sido apontado como uma espécie de alter ego do autor, faz lembrar um personagem com comportamento franciscano. Os pássaros respeitam o seu silêncio e com ele se comunicam. Bernardo merece ser conhecido através de uma poética estranhada. Ele é um encantador de amanhecer, a ponto de os pássaros pousarem em seus ombros. Bernardo é um personagem mítico-pantaneiro.

Verificamos, pela análise dos resumos das comunicações apresentadas, que os termos mudaram, mas o fundamento da "beleza literária", subordinado à "beleza da forma e da matéria poéticas" preconizado por Aquino Corrêa como essenciais para, criticamente, se pensar uma literatura que "valha a pena", permanece sob olhares

\footnotetext{
${ }^{104}$ Professora do Departamento de Letras da Universidade do Estado de Mato Grosso (Unemat/Campus de Pontes e Lacerda).
} 
críticos que tratam de atualizar os modos de ser e de ver a poesia produzida por escritores mato-grossenses.

Ainda que os termos 'forma' e 'matéria' soem como ecos da tradição, estes traços perduram como elementos essenciais à realização de uma crítica literária consciente, resultante de um processo complexo de expansão e conquista de um espaço cultural advindo de ações coletivas, compreendidas desde a vontade do escritor expressa em uma obra, até as atitudes analíticas dos inúmeros estudiosos e pesquisadores que se dedicam, em uma perspectiva teórica mais abrangente, a dar corpo e relevância adequados à crítica literária, em um âmbito mais alargado dos estudos literários. 


\section{BIBLIOGRAFIA}

\section{A. Do autor}

CORREA, Dom Francisco de Aquino. Discursos, Vol. II, Tomo I, Edição Comemorativa do Centenário de Nascimento do Autor. Brasília: Ex-libris, 1985 d. , 291 p.

. Discursos, Vol. II, Tomo II, Tomo II, Edição Comemorativa do Centenário de Nascimento do Autor. Brasília: Ex-libris, 1985 e. 185 p.

. Discursos, Vol. II, Tomo III, Edição Comemorativa do Centenário de Nascimento do Autor. Brasília: Ex-libris, 1985 f. 185 p.

. Poética : Nova et Vetera. Edição Comemorativa do Centenário de Nascimento do Autor. Vol. I, Tomo I, Brasília: Ex-libris, 1985 c. 212 p.

. Poética: Odes. , Vol. I, tomo II, Edição Comemorativa do Centenário de Nascimento do Autor. Brasília:1985 a . 230 p.

. Poética: Terra Natal. Edição Comemorativa do Centenário de Nascimento do Autor. Brasília: 1985 b, Vol.1, Tomo III, 185 p.

\section{B. Sobre o autor}

COMETTI, Padre Pedro. Dom Aquino Corrêa - Arcebispo de Cuiabá: vida e obra. Brasília: Centro Gráfico do Senado Federal, 1994.

NETO, João Antônio Neto. Dom Aquino, o orador e O Modernismo em Mato Grosso: reencontro com Silva Freire. Cuiabá: Prefeitura Municipal de Cuiabá, 2001.

\section{Da Literatura do Mato Grosso}

CARVALHO, Carlos Gomes de. A poesia em Mato Grosso. Cuiabá: Verdepantanal, 2003.

MAGALHÃES, Hilda Gomes Dutra. A História da Literatura de Mato Grosso: Século XX. Cuiabá: Unicen Publicações, 2001. 
MENDONÇA, Rubens de.História da literatura mato-grossense. 2.ed. Especial. Cáceres: Editora da Unemat, 2005.

PÓVOAS, Lenine Campos. História da cultura mato-grossense. São Paulo: Editora Resenha Tributária Ltda, 1982.

. História geral de Mato Grosso: dos primórdios à queda do império, Vol. I. Cuiabá: L.C. Póvoas, 1995.

. História Geral do Mato Grosso: da Proclamação da República aos dias atuais. Vol. II. Cuiabá: L.C. Póvoas, 1995.

SIQUEIRA, Elizabeth Madureira, COSTA, Lourença Alves da, CARVALHO, Cathia Maria Coelho. O processo histórico de Mato Grosso. Cuiabá: Guaicurus, 1990.

RAMOS, Isaac Newton; RODRIGUES, Agnaldo. (Org.) Ensaios em literatura Comparada: Portugal, Brasil, Angolae Cabo Verde. Cáceres: UNEMAT Editora, 2004.

DELBEM, Nancy Lopes Yung. Imortalidade e discursos: a presença lusitana e a língua portuguesa no espaço cultural de Mato Grosso. São Paulo: 2002. 272 f. Dissertação (Mestrado em Estudos Comparados de Literaturas de Língua Portuguesa), Departamento de Letras Clássicas e Vernáculas da Faculdade de Filosofia, Letras e Ciências Humanas da Universidade de São Paulo.

\section{GERAL}

ABDALA JR, Benjamin. De Vôos e Ilhas: Literatura e Comunitarismo. São Paulo:Ateliê Editorial, 2003.

. Viajantes e Viagens. In: De Vôos e Ilhas:Literatura e Comunitarismo.São Paulo:Ateliê Editorial, 2003, p.13-62(texto).

AGUIAR e SILVA, Vítor Manuel de. Teoria da Literatura. 8.ed. Vol. I. Coimbra: Livraria Almedina, 2000.

ARISTóteleS. Arte Poética: Texto integral. Trad. Pietro Nassetti. São Paulo: Editora Martin Claret, 2004.

BAKHTIN, Mikhail Mikhailovitch (1895-1975).Estética da criação verbal. Trad. Maria Ermantina Galvão.3.ed. São Paulo:Martins Fontes, 2000.Coleção ensino superior. 
. Marxismo e filosofia da linguagem. Trad. Michel Lahud e Yara Frateschi Vieira. 9.ed. São Paulo:Hucitec, 1999.

BARTHES, Roland. Inéditos: teoria. Trad. Ivone Castilho Benedetti. São Paulo: Martins Fontes, 2004.

. O grau zero da escrita: seguido de novos ensaios críticos. 2.ed. São Paulo: Martins Fontes, 2004.

BAUDELAIRE, Charles. Sobre a Modernidade. São Paulo: Editora Paz e Terra, 2002. BOAVENTURA CARDOSO, A escrita em processo. Org. Rita Chaves, Tânia Macedo, Inocência Mata. São Paulo: Alameda, União dos escritores Angolanos, 2005.

BOSI, Alfredo. Dialética da Colonização. 4. ed. São Paulo: Companhia das Letras, 2002.

. Literatura e resistência.São Paulo: Companhia das Letras, 2002.

. O ser e o tempo da poesia. São Paulo: Companhia das Letras, 2004.

BOSI, Ecléa. Memória e sociedade: lembranças dos velhos. 3. ed. São Paulo: Companhia das Letras, 1994. 484p.

BRUNEL, P. PICHOIS, C. e ROUSSEAU, M. Que é literatura Comparada. São Paulo: Perspectiva, 1990

CÂNDIDO, Antônio. Educação pela noite e outros ensaios. 3.ed. São Paulo:Ática, 2003.

. Literatura e sociedade: estudos de teoria e história literária. 8.ed. -São Paulo:T. A . Queiroz Editor, 2000.

. Formação da Literatura Brasileira: momentos decisivos(1836-1880).Vol.1. 7.ed..Belo Horizonte-Rio de Janeiro: Editora Itatiaia Limitada, 1993.

.Formação da Literatura Brasileira: momentos decisivos (1836-1880). Vol.2. 7. ed. Belo Horizonte-Rio de Janeiro:Editora Itatiaia Limitada, 1993.

.O estudo analítico do poema. 5. ed. São Paulo: Associação Editorial Humanitas, 2006. 164p.

CANIATO, Benilde Justo. Percursos por África e por Macau.Cotia, SP: Ateliê Editorial, 2005.

CARVALHO, José G. Herculano de. Teoria da linguagem: natureza do fenômeno lingüístico e a análise das línguas.Coimbra: Atlântica Editora, 1973. 
CASTRO, E.M. de Melo e. O Fim Visual do Século XX \& Outros Textos Críticos.Nádia Battella Gotlib (org.).São Paulo: Editora da Universidade de São Paulo, 1993. . Poesia/Transpoesia/Repoesia: alguns tópicos atuais nas poesias brasileira e portuguesa.Revista USP.São Paulo: 36, 116-127.Dezembro/Fevereiro, 1997-98.

CHEVALIER, Jean, Dicionário de Símbolos: (mitos, sonhos, costumes, gestos, formas, figuras, cores, números),CHEVALIER; Jean, GHEERBRANT, Alain. Colaboraçã: André Barbault...[et al.]; coordenaçã Carlos Sussekind; trad. Vera da Costa e Silva...[et al].-ed. 15. Rio de Janeiro: José Olímpio, 2000.

COMPAGNON, Antoine. O demônio da teoria: literatura e senso comum. Trad. Cleonice Paes Barreto Mourão, Consuelo Fontes Santiago. Belo Horizonte: Ed. UFMG, 2001. COUTINHO, Afrânio. A literatura no Brasil. Vol. I. Rio de Janeiro: Editorial Sul Americana, 1955..

. As formas da literatura brasileira. São Paulo: Bloch Editores, S.A., 1983.

- Introdução à literatura no Brasil. 3. ed. Rio de Janeiro: Livraria São José, 1966.

- A literatura no Brasil: introduções : Barroco, Neoclassicismo, Arcadismo. Vol. I. Rio de Janeiro: Editorial Sul Americana S.A , 1968.

CROCE, Benedetto. Estética: come scienza dell' espressione e lingüística generale: teoria e storia. Milão:Adelphi, 1990, 1.ed.,1902)

DIAS-PINO, Wladimir. Processo: linguagem e comunicação. 3. ed. Rio de Janeiro Petrópolis: Editora Vozes, 1973.

DUCROT, Oswald. TODOROV, Tzvetan. Dicionário Enciclopédico das Ciências da Linguagem. São Paulo: Editora Perspectiva, 2001.

ECO, Umberto. Estética: As Formas do conteúdo. Trad. Pérola de Carvalho. 3. ed. São Paulo: Perspectiva 2001.

. Leitura do texto literário: Ilector in fabula. Trad. Mário Brito. 2. ed. Lisboa: Editorial Presença, 1993.

ELIA, Silvio. A unidade lingüística do Brasil: condicionamentos geoeconômicos. Rio de Janeiro: Padrão Livraria Editora Ltda, 1979. 
Em Associação Brasileira de Literatura Comparada - Congresso. Cânones \& Contextos: 5ํㅡㄹ Congresso da ABRALIC, 30 de julho a 02 de agosto, anais, Vol. 3, p.1041-1045, Rio de Janeiro: 1998.

GARCEZ, Maria Helena Nery. Trilhas em Fernando Pessoa e Mário de Sá-Carneiro. São Paulo: Moraes: Editora da Universidade de São Paulo, 1989.

GUILLÉN (1989) em Teorias de la historia literária .Madrid:Espasa-Calpe, S.A., 1989.

. Entre lo uno y lo diverso: introducción a la literatura comparada. Barcelona: Editorial Crítica, 1985.

HAMBURGER, Käte. A lógica da criação literária. Trad. Margot P. Malnic. 2. ed. São Paulo: Perspectiva, 1986.

HEGEL, Georg Wilhelm Friedrich. Cursos de Estética. Trad. Marco Aurélio Werle; rev. Téc. Márcio Seligmann-Silva; cons.Victor Knoll e Oliver Tolle. 2. ed.ver. São Paulo: Editora da Universidade de São Paulo, 2001. (Clássicos-14)

HUTCHEON, Linda. Poética do pós-modernismo: história teoria e ficção. Trad. Ricardo Cruz. Rio de Janeiro: Imago Ed, 1991.

JAKOBSON, Roman. Lingüística e comunicação. Aspectos lingüísticos da tradução, pp.63 a 72. Trad. Izidoro Blikstein e José Paulo Paes. 19.ed. São Paulo: Cultrix, 2003.

JAMESON, Fredric, (1934-), Modernidade Singular. Trad. Roberto de Franco Valente. Rio de Janeiro: Civilização Brasileira, 2005.

LIMA, Luiz Costa. Sociedade e discurso ficcional. Rio de Janeiro: Guanabara, (s/d).

MACHADO, Álvaro Manuel. PAGEAUX, Daniel Henri.Da Literatura Comparada à Teoria da Literatura.. 2. ed. Lisboa: Editorial Presença, 2001.

MAINGUENEAU, Dominique. O contexto da obra literária: enunciação, escritor, sociedade. Trad. Marina Appenzeller; ver. Trad. Eduardo Brandão, 2. ed. São Paulo: Martins Fontes, 2001.

. Pragmática para o discurso literário.Trad. Marina Appenzeller. Ver. da trad. Eduardo Brandão. São Paulo: Martins Fontes, 1996. (Coleção Leitura e Crítica).

MARCUSCHI, Luiz Antônio. Leitura como processo inferencial num universo culturalcognitivo. In: Leitura: Teoria e Prática, o 5, ano 4. Porto Alegre: ALB/Mercado Aberto, junho de 1985. Publicado originalmente nos Anais do I Encontro Interdisciplinar de Leitura. Universidade Estadual de Londrina, Londrina, 1984: 
MARITAIN, Jacques. Humanismo Integral. Trad. De Afrânio Coutinho. São Paulo:Companhia das Letras, 1945.

- Humanismo Integral: introdução, heroísmo e humanismo-noção geral do humanismo. In. http:www.maritain.org.Br/livros/HI_introdução.htm (11/09/06)

MATOS, Joaquim. "Um espaço na modernidade", ensaio publicado na revista eletrônica.Letras \& Letras/wwwalfarrabios.di.uminho.pt/vercial/letras/ensa

NITRINI, Sandra. Literatura Comparada: história, teoria e crítica. 2. ed. São Paulo: Editora da Universidade de São Paulo, 2000.

PAREYSON, Luigi. I Problemi dell' Estetica, ed. 2. Milano: Marzoti Editora, 1966.

PAVEAU, Marie-Anne, SARFATI, Georges Elia. As grandes teorias da lingüística: da gramática comparada à pragmática.Trad. M.R.Gregolin et al. São Paulo: Claraluz, 2006. PEREIRA, José Carlos Seabra. História Critica da Literatura Portuguesa: do Fim - de Século ao Modernismo, Vol. VII, 2. ed. Coord. Carlos Reis. Lisboa / São Paulo: Editorial Verbo, 2003.

PINTO, Edith Pimentel. O escritor enfrenta a língua. São Paulo: FFLCH-USP, 1994.

REBELO, Luís de Sousa. A tradição clássica na literatura portuguesa. Lisboa: Livros Horizontes, 1980.

RODRIGUES, Sara Viola. Os limiares da crítica da tradução na pós-modernidade. In: CARVALHAL, Tânia Franco (Coord.).Culturas, contextos e discursos: limiares críticos do comparatismo. Porto Alegre: Ed. Universidade/UFRS, 1999

ROMERO, Sílvio. História da literatura brasileira, tomo II. Ed. Comemorativa. Rio de Janeiro: Imago; Aracaju: Universidade Federal de Sergipe, 2001.

SARAIVA, Antonio José, LOPES, Oscar. História da literatura portuguesa. 8. ed. Porto: Porto Editora Ltda.

SAUSSURE, Ferdinand de. Curso de Lingüística Geral.Org.Charles Bally e Albert Sechehaye.Trad. Antônio Cheline et al. São Paulo: Cultrix, 1997.

SILVA NETO, Serafim da. História da Língua Portuguesa. 2. ed. Rio de Janeiro: Livros de Portugal, 1970.

SODRÉ, Nelson Werneck, História da imprensa no Brasil. 4. ed. Rio de Janeiro: Mauad, 1999. 
SPINA, Segismundo. Na madrugada das formas poéticas. 2.ed. São Paulo: Ateliê Editorial, 2002

SPITZER, Leo. Lingüística e história literária. 2. ed. Madrid: Editorial Gredos, 1961. TODOROV, Tzvetan. Simbolismo e interpretação.Trad. Maria da Santa Cruz. Lisboa: Edições 70, 1978.

WELLEK, René; WARREN. Austin. Teoria da literatura e metodologia dos estudos literários.Trad.Luís Carlos Borges.Ver.trad.Silvana Vieira.São Paulo: Martins Fontes, 2003.(Coleção leitura e crítica).

\section{E. APOSTILAS}

CANIATO, Benilde Justo. Linguagem, língua, língua literária: breves considerações. São Paulo, dezembro de 2003.

COUTINHO, Afrânio. As formas da literatura brasileira. São Paulo: Bloch Editores, S.A. , 1983. (parte II, Gênero lírico, pp. 191-337)

COUTINHO, Afrânio. A literatura no Brasil. Vol. I . Rio de Janeiro: Editorial Sul Americana, 1955. (Cap. A língua literária, pp. 101 a 110) (Cap. O folclore: literatura oral e literatura popular-pp.115-126)Estes 2 capítulos juntamente com as idéias de SPINA.

SPITZER, Léo. Lingüística e história literária. 2.ed. Madrid:Editorial Gredos, 1974. (Cap. I, pp. 7 a 53)

LIMA, Luiz Costa. Sociedade e discurso ficcional. pp.360 a 368.

\section{F. CONGRESSOS E SIMPÓSIOS}

LUGARES DOS DISCURSOS, X CONGRESSO INTERNACIONAL ABRALIC, 2006, Rio de Janeiro: ABRALIC, 2006. CD-ROM.

SIMPÓSIO - NA AUDIÊNCIA DO TEMPO: REGIONALISMO E INTERTEXTUALIDADE NA LITERATURA DE MATO GROSSO, X Congresso Internacional ABBRALIC, 2006. Rio de Janeiro. Sentidos dos lugares/ Lugares dos discursos. Rio de Janeiro: ABRALIC, 2006. 192p. 


\section{G. NORMAS tÉCNICAS}

Diretrizes para apresentação de dissertações e teses da USP: documento eletrônico e impresso. Sistema Integrado de Bibliotecas - SIBi, www.fflch.usp.sp/pos/index. São Paulo: 2004.

Normas para publicações da UNESP/Coordenadoria Geral de Bibliotecas e Editora UNESP - São Paulo: Editora da Universidade Estadual Paulista, 1994.

RODRIGUES, André Figueiredo.Como elaborar referência bibliográfica.2.ed. São Paulo:Humanitas/FFLCH/USP, 2004.80p. .Como elaborar citações e notas de rodapé.3.ed. v.2.São Paulo:Associação Editorial Humanitas, 2005.

.Como elaborar e apresentar monografias. São Paulo:Associação Editorial Humanitas, 2005.93 p. (Coleção Metodologias, v.3.) 


\section{BIBLIOGRAFIA}

\section{A. Do Autor}

CORREA, Dom Francisco de Aquino. Discursos, Vol. II, Tomo I, Edição Comemorativa do Centenário de Nascimento do Autor. Brasília: Ex-libris, 1985 d. , 291 p.

- Discursos, Vol. II, Tomo II, Tomo II, Edição Comemorativa do Centenário de Nascimento do Autor. Brasília: Ex-libris, 1985 e. 185 p.

. Discursos, Vol. II, Tomo III, Edição Comemorativa do Centenário de Nascimento do Autor. Brasília: Ex-libris, 1985 f. 185 p.

- Poética : Nova et Vetera. Edição Comemorativa do Centenário de Nascimento do Autor. Vol. I, Tomo I, Brasília: Ex-libris, 1985 c. 212 p.

. Poética: Odes. , Vol. I, tomo II, Edição Comemorativa do Centenário de Nascimento do Autor. Brasília:1985 a . 230 p.

. Poética: Terra Natal. Edição Comemorativa do Centenário de Nascimento do Autor.

Brasília: 1985 b, Vol.1, Tomo III, 185 p.

\section{B. Sobre o autor}

COMETTI, Padre Pedro. Dom Aquino Corrêa - Arcebispo de Cuiabá: vida e obra. Brasília: Centro Gráfico do Senado Federal, 1994.

NETO, João Antônio Neto. Dom Aquino, o orador e O Modernismo em Mato Grosso: reencontro com Silva Freire. Cuiabá: Prefeitura Municipal de Cuiabá, 2001.

\section{Da Literatura do Mato Grosso}

CARVAlHO, Carlos Gomes de. A poesia em Mato Grosso. Cuiabá: Verdepantanal, 2003.

MAGALHÃES, Hilda Gomes Dutra. A História da Literatura de Mato Grosso: Século XX. Cuiabá: Unicen Publicações, 2001.

MENDONÇA, Rubens de.História da literatura mato-grossense. 2.ed. Especial. Cáceres: Editora da Unemat, 2005. 
PÓVOAS, Lenine Campos. História da cultura mato-grossense. São Paulo: Editora Resenha Tributária Ltda, 1982.

. História geral de Mato Grosso: dos primórdios à queda do império, Vol. I. Cuiabá: L.C. Póvoas, 1995.

. História Geral do Mato Grosso: da Proclamação da República aos dias atuais. Vol. II. Cuiabá: L.C. Póvoas, 1995.

SIQUEIRA, Elizabeth Madureira, COSTA, Lourença Alves da, CARVALHO, Cathia Maria Coelho. O processo histórico de Mato Grosso. Cuiabá: Guaicurus, 1990.

RAMOS, Isaac Newton; RODRIGUES, Agnaldo. (Org.) Ensaios em literatura Comparada: Portugal, Brasil, Angolae Cabo Verde. Cáceres: UNEMAT Editora, 2004.

DELBEM, Nancy Lopes Yung. Imortalidade e discursos: a presença lusitana e a língua portuguesa no espaço cultural de Mato Grosso. São Paulo: 2002. 272 f. Dissertação (Mestrado em Estudos Comparados de Literaturas de Língua Portuguesa), Departamento de Letras Clássicas e Vernáculas da Faculdade de Filosofia, Letras e Ciências Humanas da Universidade de São Paulo.

\section{GERAL}

ABDALA JR, Benjamin. De Vôos e Ilhas: Literatura e Comunitarismo. São Paulo:Ateliê Editorial, 2003.

. Viajantes e Viagens. In: De Vôos e Ilhas:Literatura e Comunitarismo.São Paulo:Ateliê Editorial, 2003, p.13-62(texto).

AGUIAR e SILVA, Vítor Manuel de. Teoria da Literatura. 8.ed. Vol. I. Coimbra: Livraria Almedina, 2000.

ARISTÓTELES. Arte Poética: Texto integral. Trad. Pietro Nassetti. São Paulo: Editora Martin Claret, 2004.

BAKHTIN, Mikhail Mikhailovitch (1895-1975).Estética da criação verbal. Trad. Maria Ermantina Galvão.3.ed. São Paulo:Martins Fontes, 2000.Coleção ensino superior. . Marxismo e filosofia da linguagem. Trad. Michel Lahud e Yara Frateschi Vieira. 9.ed. São Paulo:Hucitec, 1999. 
BARTHES, Roland. Inéditos: teoria. Trad. Ivone Castilho Benedetti. São Paulo: Martins Fontes, 2004.

. O grau zero da escrita: seguido de novos ensaios críticos. 2.ed. São Paulo: Martins Fontes, 2004.

BAUDELAIRE, Charles. Sobre a Modernidade. São Paulo: Editora Paz e Terra, 2002.

BOAVENTURA CARDOSO, A escrita em processo. Org. Rita Chaves, Tânia Macedo, Inocência Mata. São Paulo: Alameda, União dos escritores Angolanos, 2005.

BOSI, Alfredo. Dialética da Colonização. 4. ed. São Paulo: Companhia das Letras, 2002. . Literatura e resistência.São Paulo: Companhia das Letras, 2002. . O ser e o tempo da poesia. São Paulo: Companhia das Letras, 2004.

BOSI, Ecléa. Memória e sociedade: lembranças dos velhos. 3. ed. São Paulo: Companhia das Letras, 1994. 484p.

BRUNEL, P. PICHOIS, C. e ROUSSEAU, M. Que é literatura Comparada. São Paulo: Perspectiva, 1990

CÂNDIDO, Antônio. Educação pela noite e outros ensaios. 3.ed. São Paulo:Ática, 2003. . Literatura e sociedade: estudos de teoria e história literária. 8.ed. -São Paulo:T. A . Queiroz Editor, 2000. . Formação da Literatura Brasileira: momentos decisivos(1836-1880).Vol.1. 7.ed..Belo Horizonte-Rio de Janeiro: Editora Itatiaia Limitada, 1993. .Formação da Literatura Brasileira: momentos decisivos (1836-1880). Vol.2. 7. ed. Belo Horizonte-Rio de Janeiro:Editora Itatiaia Limitada, 1993. .O estudo analítico do poema. 5. ed. São Paulo: Associação Editorial Humanitas, 2006. 164p.

CANIATO, Benilde Justo. Percursos por África e por Macau.Cotia, SP: Ateliê Editorial, 2005. CARVALHO, José G. Herculano de. Teoria da linguagem: natureza do fenômeno lingüístico e a análise das línguas.Coimbra: Atlântica Editora, 1973.

CASTRO, E.M. de Melo e. O Fim Visual do Século XX \& Outros Textos Críticos.Nádia Battella Gotlib (org.).São Paulo:Editora da Universidade de São Paulo, 1993.

- Poesia/Transpoesia/Repoesia: alguns tópicos atuais nas poesias brasileira e portuguesa.Revista USP.São Paulo: 36, 116-127.Dezembro/Fevereiro, 1997-98. 
CHEVALIER, Jean,Dicionário de Símbolos: (mitos, sonhos, costumes, gestos, formas, figuras, cores, números),CHEVALIER; Jean, GHEERBRANT, Alain.Colaboraçã:André Barbault...[et al.]; coordenaçã Carlos Sussekind; trad.Vera da Costa e Silva...[et al].-ed.15.Rio de Janeiro:José Olímpio, 2000.

COMPAGNON, Antoine. O demônio da teoria: literatura e senso comum. Trad. Cleonice Paes Barreto Mourão, Consuelo Fontes Santiago. Belo Horizonte: Ed. UFMG, 2001.

COUTINHO, Afrânio. A literatura no Brasil. Vol. I. Rio de Janeiro: Editorial Sul Americana, 1955.

. As formas da literatura brasileira. São Paulo: Bloch Editores, S.A., 1983.

- Introdução à literatura no Brasil. 3. ed. Rio de Janeiro: Livraria São José, 1966.

. A literatura no Brasil: introduções : Barroco, Neoclassicismo, Arcadismo. Vol. I. Rio de Janeiro: Editorial Sul Americana S.A., 1968.

CROCE, Benedetto. Estética:come scienza dell'espressione e lingüística generale: teoria e storia. Milão:Adelphi, 1990, 1.ed.,1902)

DIAS-PINO, Wladimir. Processo: linguagem e comunicação. 3. ed. Rio de Janeiro - Petrópolis: Editora Vozes, 1973.

DUCROT, Oswald. TODOROV, Tzvetan. Dicionário Enciclopédico das Ciências da Linguagem. São Paulo: Editora Perspectiva, 2001.

ECO, Umberto. Estética: As Formas do conteúdo. Trad. Pérola de Carvalho. 3. ed. São Paulo: Perspectiva 2001.

. Leitura do texto literário: llector in fabula. Trad. Mário Brito. 2. ed. Lisboa: Editorial Presença, 1993.

ELIA, Silvio. A unidade lingüística do Brasil: condicionamentos geoeconômicos.Rio de Janeiro: Padrão Livraria Editora Ltda, 1979.

Em Associação Brasileira de Literatura Comparada - Congresso. Cânones \& Contextos: $5^{\circ}$ Congresso da ABRALIC, 30 de julho a 02 de agosto, anais, Vol. 3, p.1041-1045, Rio de Janeiro:1998.

GARCEZ, Maria Helena Nery. Trilhas em Fernando Pessoa e Mário de Sá-Carneiro. São Paulo: Moraes: Editora da Universidade de São Paulo, 1989.

GUILLÉN (1989 ) em Teorias de la historia literária .Madrid:Espasa-Calpe, S.A., 1989. 
. Entre lo uno y lo diverso: introducción a la literatura comparada. Barcelona: Editorial Crítica, 1985.

HAMBURGER, Käte.A lógica da criação literária. Trad. Margot P. Malnic. 2.ed. São Paulo:Perspectiva, 1986.

HEGEL, Georg Wilhelm Friedrich. Cursos de Estética.Trad. Marco Aurélio Werle; rev. Téc.Márcio Seligmann-Silva; cons.Victor Knoll e Oliver Tolle. 2.ed.ver. São Paulo: Editora da Universidade de São Paulo, 2001.(Clássicos-14)

HUTCHEON, Linda. Poética do pós-modernismo: história teoria e ficção. Trad. Ricardo Cruz. Rio de Janeiro: Imago Ed, 1991.

JAKOBSON, Roman. Lingüística e comunicação. Aspectos lingüísticos da tradução, pp.63 a 72. Trad. Izidoro Blikstein e José Paulo Paes. 19.ed. São Paulo:Cultrix, 2003.

JAMESON, Fredric, (1934-), Modernidade Singular.Trad. Roberto de Franco Valente. Rio de Janeiro: Civilização Brasileira, 2005.

LIMA, Luiz Costa. Sociedade e discurso ficcional. Rio de Janeiro: Guanabara, (s/d).

MACHADO, Álvaro Manuel. PAGEAUX, Daniel Henri.Da Literatura Comparada à Teoria da Literatura.. 2. ed. Lisboa: Editorial Presença, 2001.

MAINGUENEAU, Dominique. O contexto da obra literária: enunciação, escritor, sociedade. Trad. Marina Appenzeller; ver. Trad. Eduardo Brandão, 2.ed. São Paulo: Martins Fontes, 2001. . Pragmática para o discurso literário.Trad.Marina Appenzeller.Ver. da trad. Eduardo Brandão.São Paulo: Martins Fontes, 1996.(Coleção Leitura e Crítica).

MARCUSCHI, Luiz Antônio. Leitura como processo inferencial num universo culturalcognitivo. In: Leitura: Teoria e Prática, $\mathrm{n}^{\circ}$ 5, ano 4. Porto Alegre: ALB/Mercado Aberto, junho de 1985. Publicado originalmente nos Anais do I Encontro Interdisciplinar de Leitura.Universidade Estadual de Londrina, Londrina, 1984:

MARITAIN, Jacques. Humanismo Integral. Trad. De Afrânio Coutinho. São Paulo:Companhia das Letras, 1945.

. Humanismo Integral: introdução, heroísmo e humanismo-noção geral do humanismo.

In. http:www.maritain.org.Br/livros/HI_introdução.htm (11/09/06)

MATOS, Joaquim. "Um espaço na modernidade", ensaio publicado na revista eletrônica.Letras \& Letras/wwwalfarrabios.di.uminho.pt/vercial/letras/ensa 
NITRINI, Sandra. Literatura Comparada: história, teoria e crítica. 2. ed. São Paulo : Editora da Universidade de São Paulo, 2000.

PAREYSON, Luigi. I Problemi dell' Estetica, ed.2. Milano: Marzoti Editora, 1966.

PAVEAU, Marie-Anne, SARFATI, Georges Elia. As grandes teorias da lingüística: da gramática comparada à pragmática.Trad.M.R.Gregolin et al. São Paulo: Claraluz, 2006.

PEREIRA, José Carlos Seabra. História Critica da Literatura Portuguesa: do Fim - de - Século ao Modernismo, Vol. VII, 2. ed. Coord. De Carlos reis. Lisboa / São Paulo: Editorial Verbo, 2003.

PINTO, Edith Pimentel. O escritor enfrenta a língua. São Paulo: FFLCH-USP, 1994.

REBELO, Luís de Sousa. A tradição clássica na literatura portuguesa. Lisboa: Livros Horizontes, 1980

RODRIGUES, Sara Viola. Os limiares da crítica da tradução na pós-modernidade. In: CARVALHAL, Tânia Franco (Coord.).Culturas, contextos e discursos: limiares críticos do comparatismo. Porto Alegre: Ed. Universidade/UFRS, 1999

ROMERO, Sílvio. História da literatura brasileira, tomo II. Ed. Comemorativa. Rio de Janeiro: Imago; Aracaju: Universidade Federal de Sergipe, 2001.

SARAIVA, Antonio José, LOPES, Oscar. História da literatura portuguesa. 8. ed. .Porto: Porto Editora Ltda.

SAUSSURE, Ferdinand de. Curso de Lingüística Geral.Org.Charles Bally e Albert Sechehaye.Trad. Antônio Cheline et al. São Paulo: Cultrix, 1997.

SILVA NETO, Serafim da. História da Língua Portuguesa. 2. ed. Rio de Janeiro: Livros de Portugal, 1970.

SODRÉ, Nelson Werneck, História da imprensa no Brasil. 4. ed. Rio de Janeiro: Mauad, 1999.

SPINA, Segismundo. Na madrugada das formas poéticas. 2.ed. São Paulo: Ateliê Editorial, 2002

SPITZER, Leo. Lingüística e história literária. 2. ed. Madrid: Editorial Gredos, 1961. TODOROV, Tzvetan. Simbolismo e interpretação.Trad. Maria da Santa Cruz. Lisboa: Edições 70, 1978.

WELLEK , René; WARREN. Austin. Teoria da literatura e metodologia dos estudos literários.Trad.Luís Carlos Borges.Ver.trad.Silvana Vieira.São Paulo: Martins Fontes, 2003.(Coleção leitura e crítica). 


\section{APOSTILAS}

CANIATO, Benilde Justo. Linguagem, língua, língua literária: breves considerações.São Paulo, dezembro de 2003.

COUTINHO, Afrânio. As formas da literatura brasileira. São Paulo: Bloch Editores, S.A. , 1983. (parte II, Gênero lírico, pp. 191-337)

COUTINHO, Afrânio. A literatura no Brasil. Vol. I . Rio de Janeiro: Editorial Sul Americana, 1955. (Cap. A língua literária, pp. 101 a 110) (Cap. O folclore: literatura oral e literatura popular-pp.115-126)Estes 2 capítulos juntamente com as idéias de SPINA.

SPITZER, Léo. Lingüística e história literária. 2.ed. Madrid:Editorial Gredos, 1974. (Cap. I, pp. 7 a 53)

LIMA, Luiz Costa. Sociedade e discurso ficcional. pp.360 a 368.

\section{E. CONGRESSOS E SIMPÓSIOS}

LUGARES DOS DISCURSOS, X CONGRESSO INTERNACIONAL ABRALIC, 2006, Rio de Janeiro: ABRALIC, 2006. CD-ROM.

SIMPÓSIO - NA AUDIÊNCIA DO TEMPO: REGIONALISMO E INTERTEXTUALIDADE NA LITERATURA DE MATO GROSSO, X Congresso Internacional ABBRALIC, 2006. Rio de Janeiro. Sentidos dos lugares/ Lugares dos discursos. Rio de Janeiro: ABRALIC, 2006. 192p.

\section{E. NORMAS TÉCNICAS}

Diretrizes para apresentação de dissertações e teses da USP: documento eletrônico e impresso. Sistema Integrado de Bibliotecas - SIBi, www.fflch.usp.sp/pos/index. São Paulo: 2004.

Resolução COPGr No 4678/99- USP.

Normas para publicações da UNESP/Coordenadoria Geral de Bibliotecas e Editora UNESP São Paulo: Editora da Universidade Estadual Paulista, 1994. 
RODRIGUES, André Figueiredo. Como elaborar e apresentar monografias. São Paulo: Associação Editorial Humanitas, 2005.93 p. (Coleção Metodologias, v.3 ) .Como elaborar citações e notas de rodapé. 3.ed. v. 2. São Paulo: Associação Editorial Humanitas, 2005.

. Como elaborar referência bibliográfica. 2. ed. São Paulo:Humanitas/FFLCH/USP, 2004. 80p. 